\title{
MULTI-AGTOR CHALLENGES FOR DEVELOPMENT AND IMPLEMENTATION OF SUSTAINABLE MOBILITY IN RURAL AREAS IN THE NETHERLANDS
}

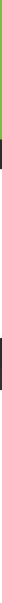

MASTER THESIS

Synthia Wierenga 


$$
80=0
$$




\section{MULTI-ACTOR CHALLENGES \\ FOR DEVELOPMENT AND}

\section{IMPLEMENTATION OF SUSTAINABLE MOBILITY IN RURAL AREAS IN THE NETHERLANDS}

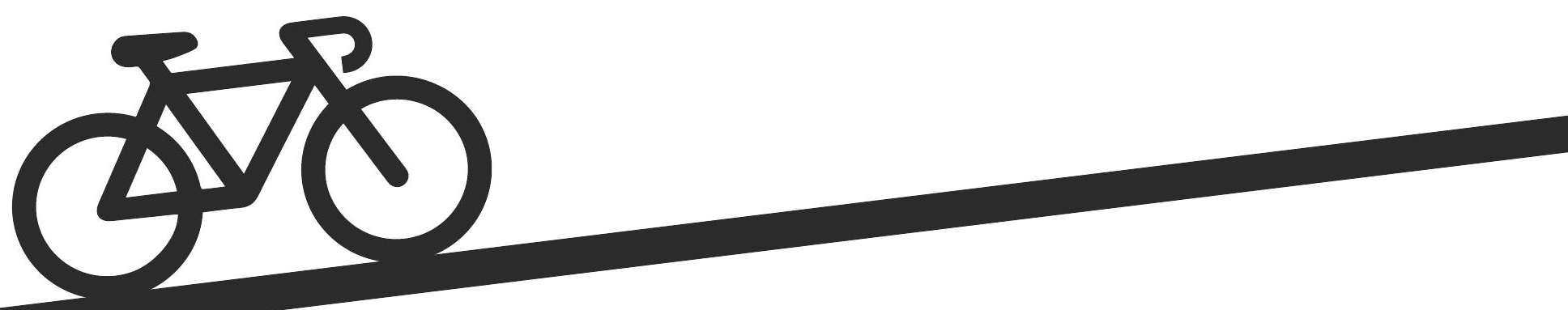

Author

Synthia Wierenga BSc

Examination Committee

Dr. Anna Grigolon (supervisor)

Dr. Sherif Amer (supervisor)

Dr. Javier Martínez (chair)

Dr. Tom Thomas (external examinar)

Master thesis submitted in partial fulfillment for the degree of Master of Science in Spatial Engineering, University of Twente, Enschede, The Netherlands

26 March 2021

Deventer, The Netherlands 


\title{
COLOPHON
}

Status

Course

Code

Name

Student number

Mail adress

Programme
Final

Academic and Research Phase (37,5 ECTS)

201900005

Synthia Winnie Maria Wierenga

2278367

s.w.m.wierenga@student.utwente.nl

synthiaswm@gmail.com

Master Spatial Engineering

ITC Faculty of Geo-Information Science and Remote Sensing

University of Twente

Supervisors:

Dr. Anna Grigolon

Ir. Mark Brussel

Dr. Sherif Amer

Maarten van Setten

\author{
University of Twente / ITC, assistant professor \\ University of Twente / ITC, lecturer/ PhD candidate \\ University of Twente / ITC, assistant professor \\ Moventem, Managing Director
}

\section{License}

This work is licensed under a Creative Commons Attribution-ShareAlike 4.0 International License.

To view a copy of this license, visit https://creativecommons.org/licenses/by-sa/4.0/

\section{Disclaimer}

No rights could be derived from the information in this thesis.

\section{Privacy statement}

In this research information has been collected from multiple stakeholders. The researcher handled this data with care. This data is exclusively used for this research and associated publications. The author won't share this data with third parties.

Key-words: sustainable mobility, transportation, travel behaviour, rural, public transportation 
"Nothing has such power to broaden the mind as the ability to investigate systematically and truly all that comes under thy observation in life."

Marcus Aurelius 


\section{TABLE OF CONTENTS}

Colophon

List of figures

viii

List of Tables

List of Maps

xii

Summary

xiv

Samenvatting

Preface

1 Introduction

1.1 Societal Relevance

1.2 Scientific relevance

1.3 Research problem

1.4 Research objectives and research questions

1.5 Reading guide

2 Theoretical framework $\quad 7$

$\begin{array}{lll}2.1 & \text { Sustainable mobility } & 7\end{array}$

2.2 Mobility in rural areas 8

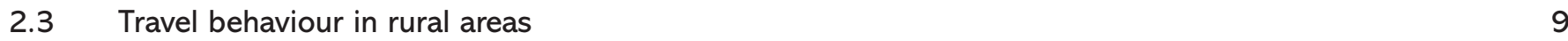

2.4 Mobility transition $\quad 10$

2.5 Conceptual framework 11

2.6 Chapter summary 12

$3 \quad$ Methodology $r$

$\begin{array}{lll}3.1 & \text { Research approach } & 15\end{array}$

3.2 Study area $\quad 16$

$\begin{array}{llr}3.3 & \text { Literature and policy analysis } & 18\end{array}$

$\begin{array}{llr}3.4 & \text { Survey } & 18\end{array}$

$\begin{array}{llr}3.5 & \text { Sampling strategy } & 19\end{array}$

3.6 In-depth interviews $\quad 19$

$\begin{array}{llr}3.7 & \text { ODiN/OViN Datasets } & 20\end{array}$

$\begin{array}{lll}3.8 & \text { Chapter summary } & 21\end{array}$ 
4 Results 23

4.1 Travel behaviour 23

4.2 Sustainable mobility from a multi-actor perspective 34

4.3 Demands and Willingness 39

4.4 Chapter summary 41

5 Discussion 43

5.1 Discussion of results 43

5.2 RESEARCH considerations 46

5.3 Ethical consideration, risks and contingencies 47

6 Conclusion 51

6.1 Conclusions 51

6.2 Recommendations for future research 52

References

Appendix 60 


\section{LIST OF FIGURES}

Figure 1. The spatial dimension (green) visualised with influences from multiple subsystems

Figure 2. Transport and Land Use feedback cycle (adapted from Wegener \& Fürst (1999)

Figure 3. NOA-model. Adapted from Vlek et. al (1997)

Figure 4.

Conceptual framework

Figure 5.

Methods per research objective (RO)

Figure 6.

Methodological research phases

Figure 7. Transport modes per distance class used in the Achterhoek

Figure 8.

Transport modes per distance class used in the Randstad

Figure 9.

Car ownership

Figure 10.

Do you have an OV - card?

Figure 11. Most used transport modes per distance class (survey output)

Figure 12. Least used transport modes per distance class (survey output)

Figure 13. Motivation for most used transport mode

Figure 14. Motivation for least used transport mode

Figure 15. Collaborations within the 8RHK (8RHK, 2019) 



\section{LIST OF TABLES}

Table 1.Urban density index (CBS, 2020d)

Table 2.Sample sizes Achterhoek per OViN and ODiN dataset

Table 3.Frequency of car use in Randstad and Achterhoek (CBS, 2019a)

Table 4.Number of cars per household 2010-2019, for the Achterhoek

Table 5.Use of transport modes between 2010 and 2019 in the Achterhoek

Table 6.Characteristics of sample population of survey and ODiN

Table 7.Travel motives per transport mode for ODiN 2019 Achterhoek

Table 8. Travel motives per transport mode for travels up to 5 kilometres (survey output)

Table 9.Travel motives per transport mode for travels between 5 and 15 kilometres (survey output)

Table 10.Travel motives per transport mode for travels longer than 20 kilometres (survey output) 



\section{LIST OF MAPS}

Map 1. Population density per squared kilometre

Map 2. Distance to nearest (Dutch) transfer station (intercity stations, in kilometres)

Map 3. Use intensity of bicycle network

Map 4. Buslines and busstop locations in the Achterhoek

Map 5. Distance to (local) train station in kilometres

Map 6. Number of respondents per PC4 area 



\section{SUMMARY}

The transition to sustainable transportation is challenging for governments, transport operators and travellers (Liu, Yu, Trisha, \& Beimborn, 2020). In this research, the challenges for development and implementation of sustainable mobility have been researched from a multi-actor perspective for the rural area. This thesis's overall research objective is: to identify the challenges and opportunities of the transition towards sustainable mobility in Dutch rural areas from a multi-actor perspective.

This overall research aim is divided into the following sub-objectives:

1. To analyse the concepts of sustainable mobility;

2. To analyse the concepts of transitions in modal choice;

3. To analyse (governmental) policies focused on transportation and sustainability in rural areas;

4. To identify and analyse differences in the travel behaviour of different groups of users;

5. To determine multi-actor demands for using or implementing sustainable travel modes.

The study area of this research is the Achterhoek. Multiple methods are used to conduct this research. A literature study was conducted into travel behaviour, sustainable transport, rural mobility, and multiple actors' role in the transition of sustainable mobility. Subsequently, an analysis was carried out of OViN and ODiN data (Onderzoek Verplaatsingen in Nederland, CBS) in which travel behaviour, motives and transport choices were presented. Besides, a survey was conducted among respondents living in the Achterhoek $(\mathrm{N}=399)$. A policy analysis at the national, provincial, and regional level has been carried out concerning (sustainable) transport and mobility to gain insight into the government's and transport operator's perspective. In-depth interviews were held with various actors in the area: the province, municipality, 8RHK (semi-government), entrepreneurs and transport operators. 
With a cooperative structure, actors aim at realising sustainable mobility. However, current policies focus on the provision of sustainable transportation instead of focusing on sustainable mobility, without a complete understanding of the needs, opportunities, and abilities of the travellers and the actors' goals. This is an important finding in understanding the challenges regarding developing and implementing sustainable mobility in rural areas. Therefore, for establishing sustainable mobility, an approach that emphasized changing travel behaviour for specific traveller groups will be more successful (Ahmed et al., 2020; Hamidi \& Zhao, 2020; Zhang \& Van Acker, 2017).

From this research it can be concluded that the current travel behaviour of the people in the Achterhoek is not very sustainable. Dominant car use, little use of public transportation and indispensability of cars according to respondents will be a challenge for governments and operators when it comes to implementation of sustainable mobility. Travellers do not play a big role in most of the policies of governments and transport operators. However, as mobility is all about someone's ability to travel from origin to destination with a certain travel mode, the travellers should also have a place in the whole transition towards sustainable mobility. Therefore, the biggest challenge is to change the travellers travel behaviour into sustainable travel behaviour. 


\section{SAMENVATING}

De transitie naar duurzaam vervoer is een uitdaging voor overheden, vervoerders en reizigers (Liu, Yu, Trisha, \& Beimborn, 2020). In dit onderzoek zijn de uitdagingen voor de ontwikkeling en implementatie van duurzame mobiliteit onderzocht vanuit een multi-actor perspectief in het landelijk gebied. Het algemene onderzoeksdoel van dit onderzoek is: het identificeren van de uitdagingen en kansen van de transitie naar duurzame mobiliteit in het Nederlandse landelijke gebied vanuit een multi-actorperspectief.

Deze algemene onderzoeksdoelstelling is onderverdeeld in de volgende subdoelstellingen:

1. Het analyseren van de concepten van duurzame mobiliteit;

2. Het analyseren van de concepten van transities in vervoerswijzen;

3. Het analyseren van (overheids)beleid gericht op vervoer en duurzaamheid in landelijke gebieden;

4. Het identificeren en analyseren van verschillen in het reisgedrag van verschillende groepen gebruikers;

5. Het bepalen van multi-actor behoefte voor het gebruik of de implementatie van duurzame reismodaliteiten.

Dit onderzoek is uitgevoerd in de Achterhoek. Er zijn meerdere methoden gebruikt om dit onderzoek uit te voeren. $\mathrm{Er}$ is een literatuurstudie gedaan naar reisgedrag, duurzaam vervoer, rurale mobiliteit, en de rol van meerdere actoren in de transitie van duurzame mobiliteit. Vervolgens is een analyse uitgevoerd van OViN en ODiN data (Onderzoek Verplaatsingen in Nederland, CBS) waarin reisgedrag, motieven en vervoerskeuzes in beeld zijn gebracht. Daarnaast is een enquête gehouden onder respondenten woonachtig in de Achterhoek $(\mathrm{N}=399)$. $\mathrm{Er}$ is een beleidsanalyse op nationaal, provinciaal en regionaal niveau uitgevoerd met betrekking tot (duurzaam) vervoer en mobiliteit om inzicht te krijgen in het perspectief van de overheid en de vervoerder. Er zijn interviews gehouden met verschillende actoren in het gebied: de provincie, gemeente, 8RHK (semi-overheid), ondernemers en vervoerders. 
Met een triple O-structuur (Overheid, Maatschappelijke Organisaties, Ondernemers) streven actoren naar het realiseren van duurzame mobiliteit. Het huidige beleid richt zich echter op het aanbieden van duurzaam vervoer in plaatsvanzichterichtenopduurzamemobiliteit. Hierdoorwordternietgekekennaardebehoeften, reismogelijkheden en capaciteiten van de reizigers (NOA-model). Dit is een belangrijke bevinding bij het begrijpen van de uitdagingen met betrekking tot het ontwikkelen en implementeren van duurzame mobiliteit in het landelijk gebied. Daarom zal een aanpak gericht op duurzame mobiliteit, met de nadruk op het veranderen van reisgedrag voor specifieke reizigersgroepen, succesvoller zijn (Ahmed et al., 2020; Hamidi \& Zhao, 2020; Zhang \& Van Acker, 2017).

Uit dit onderzoek kan geconcludeerd worden dat het huidige reisgedrag van de mensen in de Achterhoek niet erg duurzaam is. Overheersend autogebruik, weinig gebruik van openbaar vervoer en de onmisbaarheid van de auto volgens de respondenten vormen een uitdaging voor overheden en vervoerders als het gaat om de implementatie van duurzame mobiliteit. Reizigers spelen daarbij geen grote rol in de meeste beleidsmaatregelen van overheden en vervoersexploitanten. Aangezien mobiliteit echter om meer gaat dan alleen het reizen met een bepaalde vervoerswijze, moeten ook de reizigers een plaats krijgen in de hele overgang naar duurzame mobiliteit. De grootste uitdaging is dan ook om het reisgedrag van de reizigers te veranderen in duurzaam reisgedrag. 




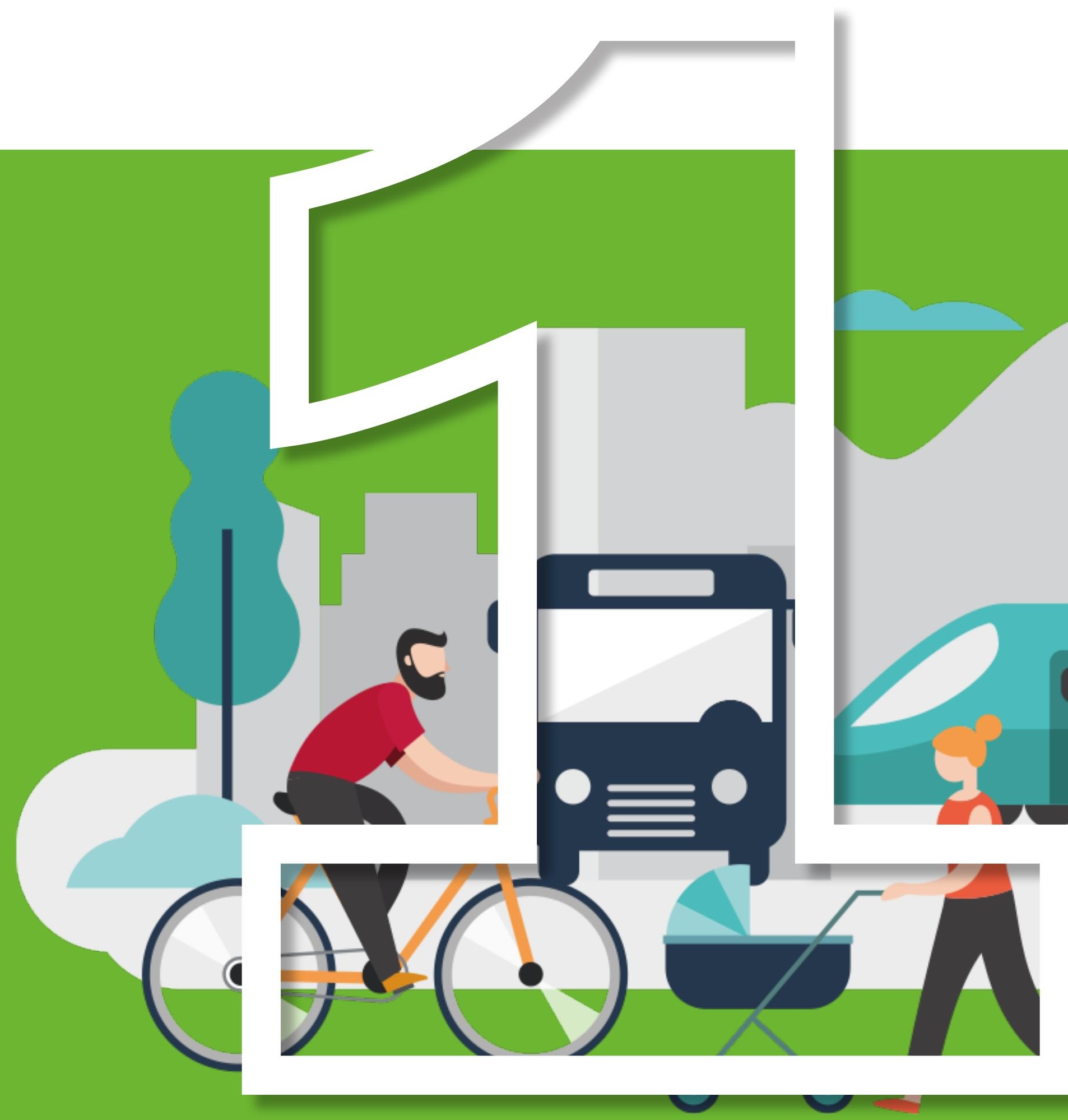




\section{INTRODUCTION}

\subsection{SOCIETAL RELEVANCE}

The transition from unsustainable transportation (e.g., emitting modes) to sustainable transportation (e.g., zero-emission modes) is challenging. Governments, public transport operators and travellers play an essential role in this transition (Liu et al., 2020). A way of dealing with this transition is with governance and planning strategies. These strategies work as an incentive to transform towards a more sustainable urban development (McCormick, Anderberg, Coenen, \& Neij, 2013). This transition requires new dimensions in transport planning and engineering where investments need to be made into sustainable transportation by (local) governments (Banister, 2008). Governments are responsible for developing sustainable transport to promote sustainable mobility and motivate the public to use clean and efficient transportation (VNG, 2019). With this sustainable transportation implementation, change in the current mobility is necessary (VNG, 2019). For instance, public transport or shared transportation could replace the car for different trip purposes (Van Putten, 2020).

The research by Prillwitz \& Barr (2011) showed that accessibility planning and development of sustainable mobility is challenging due to (i) social practices and consumer behaviour, (ii) structure and organisation of the physical environments, and (iii) the variety of political lenses for reaching societal change needed to deal with climate change. In certain situations there is a mismatch between the supply and demand of bus services (i) ("Kritiek op busvervoer in Achterhoek door Arriva," 2012)) or challenges in the management of public transportation (i) (Berends, 2018). Moreover, accessibility to rural areas' services is less compared to urban areas as Randstad (ii) (CBS, 2020a; Van Putten, 2020). There 
is a smaller population per squared kilometer living in rural areas than urban areas like the Randstad (ii) (CBS, 2020b). In the past, travelling by public transportation was common. However, car ownership and use have increased tremendously in the last 60 years. Therefore the car has become a dominant travel mode and a competitor for public transportation ${ }^{1}$ (iii) (CBS, 2019a; "Staat van het OV - CROW," 2018). Also, it is very expensive to operate a bus service (Hofs, 2019; Prillwitz \& Barr, 2011; VNG, n.d.). In practice, this means that policymakers and academics should focus more on the relation between the concealed "sociostructural" and political challenges for reaching sustainable mobility (Prillwitz \& Barr, 2011; p. 1590).

The choice for the desired travel mode is often associated with providing a fast connection between origin and destination (Salonen, Broberg, Kyttä, \& Toivonen, 2014). Simultaneously, fast connections from and to rural areas are not always possible with the current network (Hofs, 2019). More important is that there is little discussion on implementing sustainable mobility in rural and peri-urban areas (Liu et al., 2020; Shergold \& Parkhurst, 2010).
So, to work towards the implementation of sustainable mobility will be challenging.

\subsection{SCIENTIFIC RELEVANCE}

The accomplishment of sustainable mobility is defined as a 'wicked problem' (Holden, Banister, Gössling, Gilpin, \& Linnerud, 2020). A wicked problem is hard to achieve, can be seen through multiple lenses, and no solution fits everyone best (Churchman, 1967, as cited in Holden, Banister, Gössling, Gilpin, \& Linnerud, 2020). These lenses are visible in Figure 1 (Adapted from Hidding, 2006, p.99). The living environment is organised from multiple dimensions (e.g., physical, social, or spatial) and is affected by multiple subsystems (abiotic, economic, political, cultural, biotic). These dimensions and subsystems frame the context of the living environment. Each actor is mutually connected in the living environment using the subsystems (Hidding, 2006). Reaching consensus in strategic development (e.g. mobility) can only be achieved when all actors' interests from each subsystem are aligned, independent in scale or contribution to society (Holden et al., 2020; Scoones, Leach, \& Newell, 2015).

In PC4-area 7000-7999 (study area), an average amount 1.4 cars per household is registered. For the Netherlands as a whole there is an average of 1.02 cars per household (CBS, 2019a)

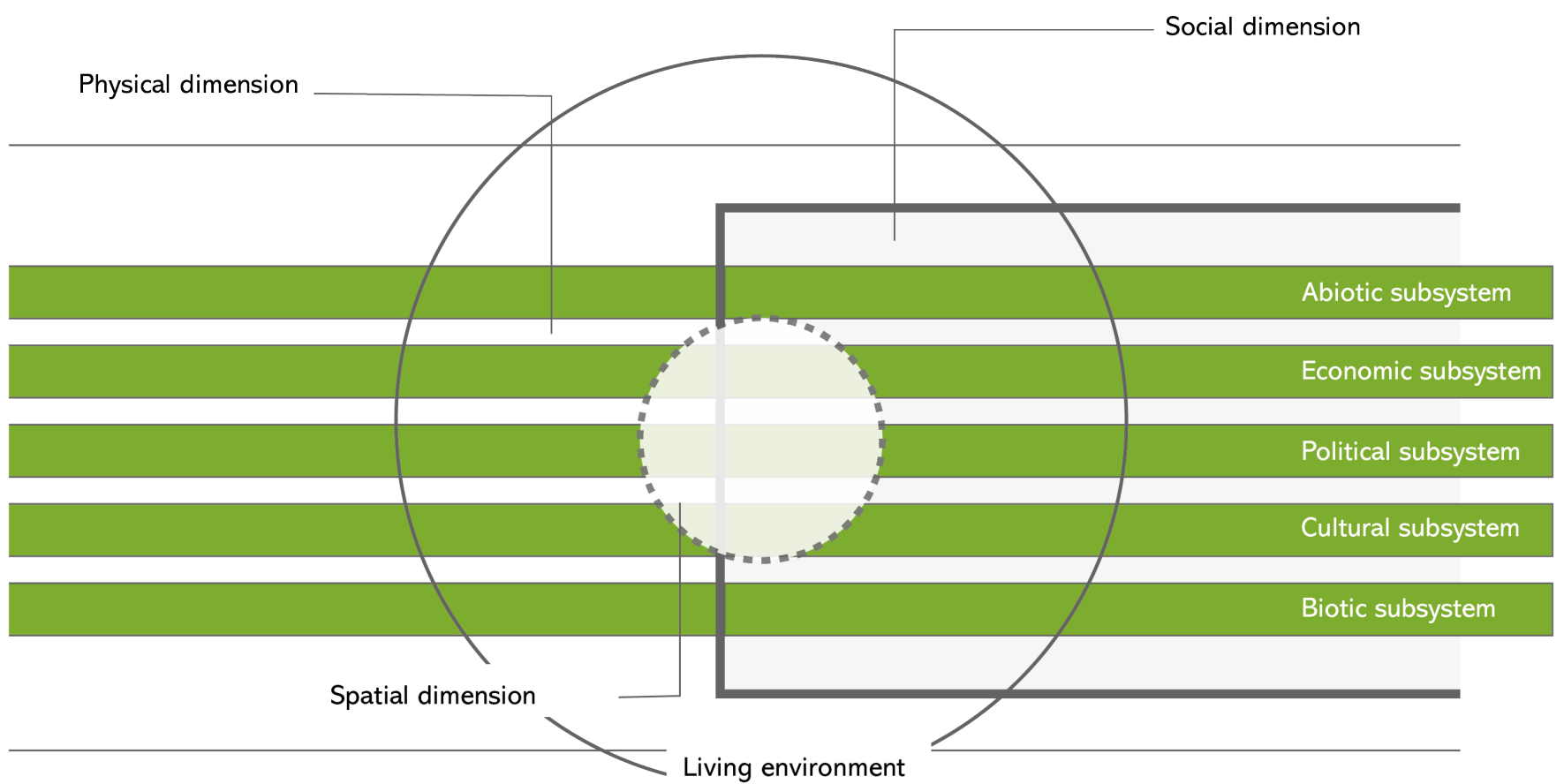

Figure 1. The spatial dimension (green) visualised with influences from multiple subsystems (Hidding 2006, p.99) 
There is less focus on developing sustainable mobility for rural areas because professionals and governments use small scales (e.g. local vs regional) and target more on urban areas (Docherty, Marsden, \& Anable, 2018; Marshall, 2001; Shergold \& Parkhurst, 2010). Rural mobility policies developed on national scales (e.g., public transportation operators) do not result in sufficient rural mobility (Mounce, Beecroft, \& Nelson, 2020). To overcome this, they suggest focusing on developing linked rural mobility services and the public transportation network in future research. Moreover, Docherty et al. (2018) say that the transition towards sustainable mobility will not be the same for all areas: it will not generate uniform accessibility to everyone.

Other studies show the importance to include rural transport justice in future research into sustainable mobility (Bastiaansen, Donkers, \& Martens, 2013; Martens, 2017; Mounce et al., 2020; Pereira, Schwanen, \& Banister, 2017). For instance, $40 \%$ of all car travels in the Netherlands are impossible or highly difficult to undertake with other transportation means (Jeekel as cited in Bastiaansen et al., 2013). Moreover, if someone is dependent on public transportation, $90 \%$ of the travels take more than twice the travel time (Jeekel as cited in Bastiaansen et al., 2013). With transport justice included in future research and policymaking, people will most likely be provisioned with a fair transport level (Brussel, 2020).

\subsection{RESEARCH PROBLEM}

There is a great potential in developing and implementing sustainable mobility as a new era to transportation. Nevertheless, implementation of sustainable mobility results in challenges for policymakers when all rural populations' demands need to be met in a sustainable way (Shergold \& Parkhurst, 2010). It is essential to face these challenges, so sustainable mobility can also be fruitful in rural areas. These transportation system users play an essential role in successfully implementing sustainable and smart mobility (Docherty et al., 2018). They are the users of a new system, and the mobility system needs to be of public value to be successful. However, a study by Brůhová Foltýnová, Vejchodská, Rybová, \& Květoň (2020) showed that perspectives of multiple actors make it challenging to achieve sustainable mobility because there are contrasting definitions of what it means and how it should be implemented. The travellers value a good trip different than a public transportation operator. Moreover, sustainable mobility is hard to achieve when policymakers do not take the responsibility to create a framework for desired mobility (e.g. road pricing) (Taylor \& Kalauskas, 2010).

It is unclear how sustainable mobility can be achieved for rural areas (developed, implemented and maintained) in rural areas both from a multi-actor perspective (Fagnant \& Kockelman, 2015) and with the three imperatives of sustainable development: "satisfying human needs, ensuring social justice, and respecting environmental limit" (Holden et al., 2020, p. 2; Liu et al., 2020). A critical assessment of the possibilities for developing and implementing sustainable mobility will help governments create (new) sustainable mobilities with benefits for all actors (Wong, Hensher, \& Mulley, 2018). Besides, to understand the different aspects of sustainable mobility, a holistic research approach is needed (Schiller \& Kenworthy, 2017). Therefore, it is necessary to identify the challenges and opportunities to transition towards sustainable mobility of rural areas from a multi-actor perspective.

\subsection{RESEARCH OBJECTIVES AND RESEARCH QUESTIONS}

This thesis's overall research objective is:

to identify the challenges and opportunities of the transition towards sustainable mobility in Dutch rural areas from a multi-actor perspective

This overall research aim is divided into the following sub-objectives

1. To identify the concepts of sustainable mobility

2. To identify the concepts of transitions in modal choice

3. To analyse (governmental) policies focused on transportation and sustainability in rural areas

4. To identify and analyse differences in the travel behaviour of different groups of users

5. To determine multi-actor demands for using or implementing sustainable travel modes

On the next page all subquestions are presented. 


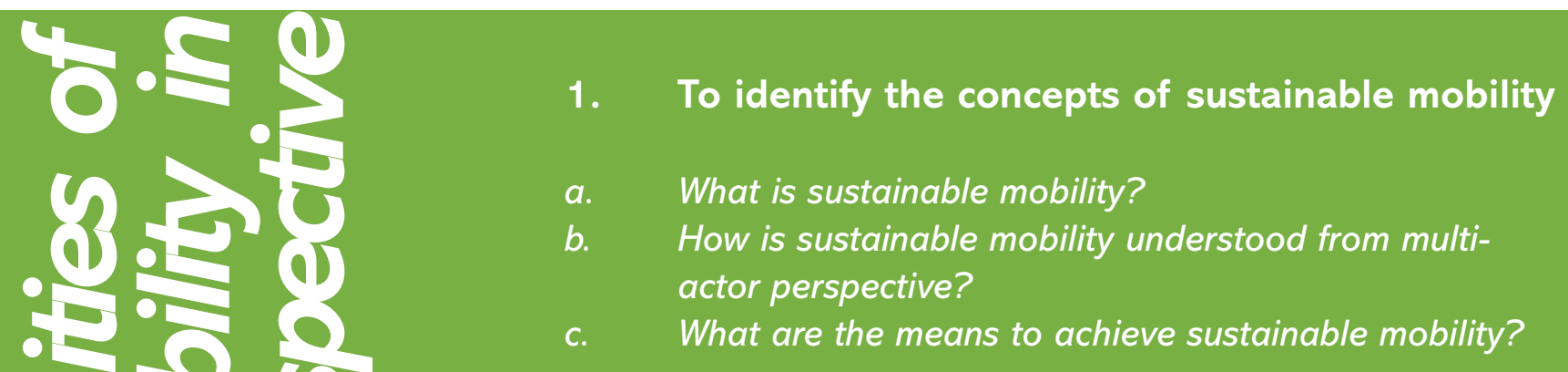

2. To identify the concepts of transitions in modal choice

a. What factors influence modal choice in general?

b. Which factors determine modal choice in the Netherlands?

3. To analyse (governmental) policies focused on transportation and sustainability in rural areas

a. How is the transport system organised in the Netherlands?

b. How is the transport system organised in rural areas in the Netherlands?

c. What are the challenges of the current transport system?

4. To identify and analyse travel behaviour of different groups of users

a. What are the differences in the travel behaviour of different groups of travellers?

b. How do different groups travellers experience transportation?

5. To determine multi-actor demands for using or implementing sustainable travel modes

a. What are the transportation requirements of multiple actors?

b. What determines the willingness to use sustainable transportation for multiple actors? 


\subsection{READING GUIDE}

The next chapters are organised in the following order. Chapter two addresses the concepts, models, and background of (sustainable) mobility, travel behaviour, rural areas, and the ongoing transition in mobility. This is summarised in a conceptual model for the study area. Chapter three addresses the methods used to conduct this research. Moreover, the study area for this research is described. In chapter four, the results are presented as results of each individual method. In chapter five, the sub questions per research objective are answered with respect to the result. In addition, the limitations, and its ethical implications of this research are addressed. Chapter six presents the final conclusions and recommendations for following research in the field of sustainable mobility. 


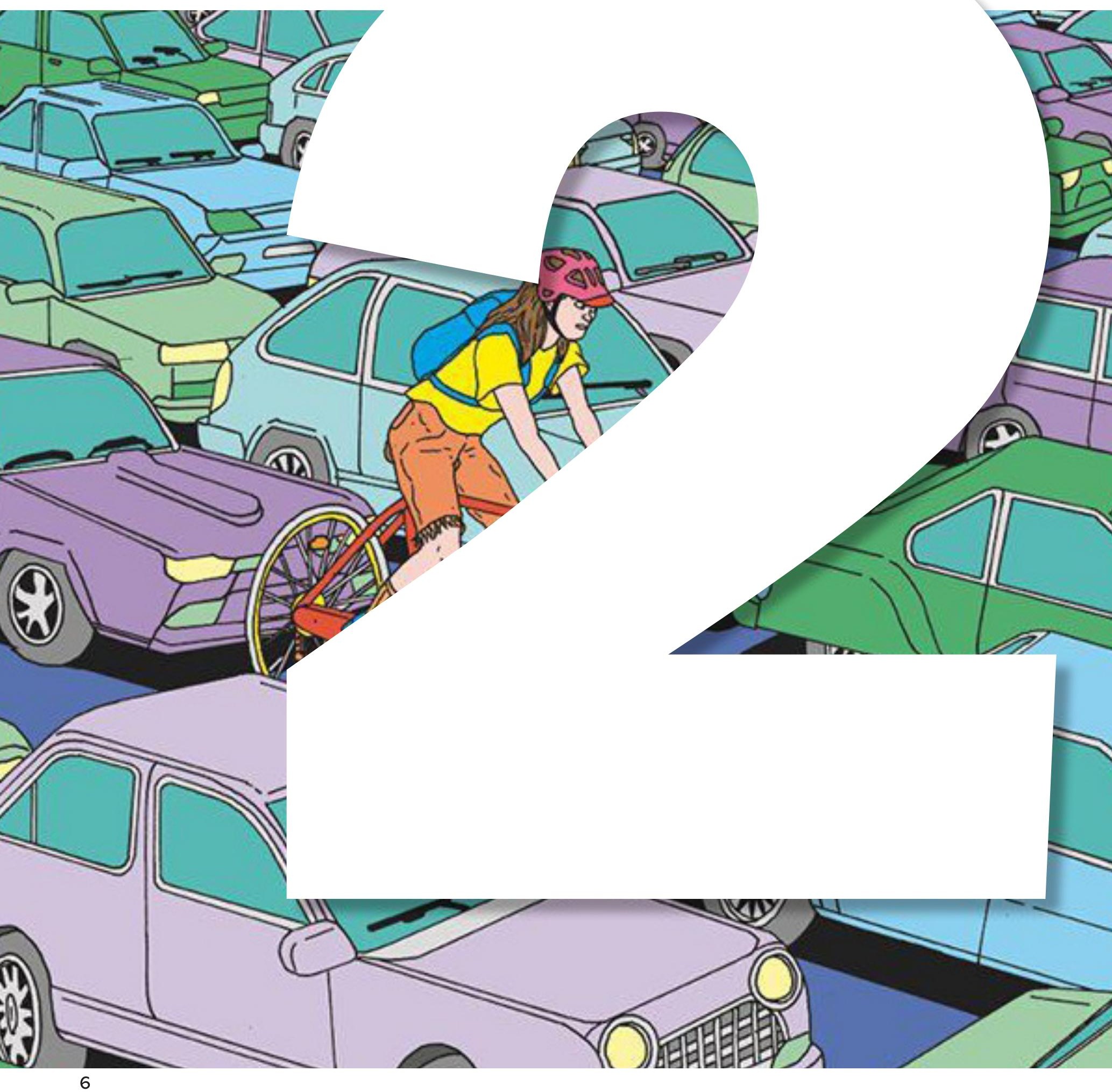




\section{THEORETICAL FRAMEWORK}

As sustainable mobility, its development and implementation have been marked as a wicked problem (Holden et al., 2020), the concepts related to sustainable mobility need to be elaborated. Many researchers focussed on this concept, mostly in urban settings. Therefore, this chapter elaborates on sustainable mobility, accessibility of rural areas, travel behaviour, multiactor developments and the overall transition towards sustainable transportation from a multiactor perspective.

\subsection{SUSTAINABLE MOBILITY}

Many studies focus on the emerged concept of transportation and sustainability. First, mobility is defined as the "ability to move from place to place" (Mitchell, 1995, p. 17), whereas accessibility is defined as the ease of reaching destinations, like jobs and services (Preston \& Rajé, 2007). As Ranković Plazinić \& Jović (2018) mentioned, mobility is not only realised to travel to facilities (e.g. shops); it is also related to the physical ability of someone to exercise or move for health benefits.

There are multiple definitions of sustainable mobility. Banister (2008) claims that sustainable mobility focuses on the environment, social problems, users' transport demand and accessibility instead of only focusing on mobility. Morency defines it as:

"[...] having an accepted understanding that mobility is the ability of people and goods to move or be transported and that this mobility is sustainable when it is created in a way that respects the safety and the environment, ensures the provision of life's material needs and guarantees fairness among individuals"
(Morency, 2013, para. 3). These two definitions of sustainable mobility are one of many. Nevertheless, there is consensus that economic development, environmental conservation and social development are part of sustainable mobility (Banister, 2008; Jeon \& Amekudzi, 2005; Morency, 2013; Tian, Tang, Che, $\& \mathrm{Wu}, 2020)$.

In this paragraph some of the principles for achieving sustainable mobility are listed. In the following paragraph these are elaborated. One of the basic principles of improving the sustainability of mobility is by emphasising the efficiency of transport systems and modal efficiency (Holden et al., 2020; Mulley \& Kronsell, 2018; Tian et al., 2020; Wong et al., 2018). Moreover, it is often understood as travelling by a zero-emission mode (Mulley \& Kronsell, 2018). When focussing on modal efficiency, smaller and flexible modes of transportation are emphasised. These modes emerge from digitalisation and collaborative use of transport modes. In an urban context, shared transport modes impact the sustainability of shared public transport modes (Le Vine \& Polak, 2015; Mulley \& Kronsell, 2018). Moreover, efficiency can be achieved by changing travel behaviour or travelling less (Holden et al., 2020). The effect of efficiency is confirmed in research conducted by Holden et al. (2020). This research presents three strategies to achieve sustainable mobility: efficiency, alteration, and reduction. First, the efficiency strategy shows that using technology (e.g., clean vehicles, trip applications) can improve environmental conduct and accessibility. With technological virtue, hindrances in the current transportation network can be reduced (Kamargianni, Matyas, Li, \& Schäfer, 2015).

Second, the alteration strategy focusses on modal 
shift and behaviour. As mentioned before, rural transport modes are dominated by cars. When the alteration strategy is followed, the rural modes also need to be replaced by more shared or collective modes. An example of this can be public transportation or shared (electrical) car use. In practice, this results in transportation being less dominated by cars, with more room for shared transportation (Brůhová Foltýnová et al., 2020; Holden et al., 2020; Le Vine \& Polak, 2015). More important within the alteration strategy, is the increase of accessibility by public transportation (which is further elaborated in chapter 2.2). Accessibility is affected by exogenous influences, like distribution of and access to activities, as individual factors like income, education, or mobility (Boisjoly \& El-Geneidy, 2017; Geurs \& Wee, 2004). Therefore, sustainable mobility must be realised without losing accessibility (Shaheen, Cohen, \& Zohdy, 2016). Therefore this strategy focuses on implementing collective and non-motorised transportation instead of individual motorised transportation (Holden et al., 2020; Mounce et al., 2020; Van Putten, 2020).

The third strategy presented by Holden et al. (2020) to achieve sustainable mobility is reduction. Within the first two strategies, emissions are yet reduced, but to maintain this, and motivate travellers even more to reduce their consumption and emission, a more integral reduction approach should be started. Therefore, the reduction strategy focusses on integral land use planning, with smaller travel distances for daily activities, shorter distances to sustainable transport modes, and an increase of distances or travel time for unsustainable transport. Also, a change in travel behaviour and preferences will positively affect the reduction of energy and emission. Another way in this strategy is by motivating stakeholders to telecommute (Holden et al., 2020).

\subsection{MOBILITY IN RURAL AREAS}

In essence, services in rural areas are more spread in geographic space compared to urban areas. The distances between villages, cities and their facilities are more extensive than in urban areas. Also, accessibility to transportation services is different compared to an urban environment. For example, rural areas are well accessible by road, but not by public transportation (Dickinson, Kingham, Copsey, \& Hougie, 2003). Public transportation services are dispersed over the area 8 and not available at each corner of the street. Most of the train stations are located in the outskirts of a village or between villages for rural areas. Therefore, essential services like shops, education or healthcare are distant from stations compared to a station located in the centre of all the services. Although services are not as close as urban located stations, a station (both bus and train) is a crucial transfer location for the area (Bureau Spoorbouwmeester, 2012).

It is challenging for both operators and governments to provide a public transportation network that serves all rural-oriented travellers due to its extensive spread service area. For public transportation in these polycentric rural areas, a subsidy is required to maintain a public transportation service (Piorr, Ravetz, \& Tosics, 2011). In urban areas, a subsidy is also required to maintain public transportation services, but the amount of subsidy needed is smaller than the subsidy needed in rural areas (Van Goevorden, Rietveld, Koelemeijer, \& Peeters, 2006).

Preston \& Rajé (2007) studied sustainable mobility by using a method to analyse rural exclusion in mobility. This method results in a matrix with the accessibility and mobility of that area, and the peoples' mobility, which can contribute to improving policies. This matrix results in a differentiated view on mobility policies where rural areas also are considered, and people shift their travel behaviour towards more sustainable travel modes. However, Preston \& Rajé (2007) did not include demographic changes (e.g. population decline, urbanisation) in their research, whereas these changes push local transportation systems to adapt their system (Milbourne \& Kitchen, 2014; Porru, Misso, Pani, \& Repetto, 2020). Furthermore, it is crucial to show the accessibility to local services and more regional or national services, because this can show the hindrances of sustainable transportation development (Bartle \& Chatterjee, 2019; Porru et al., 2020).

The demographic characteristics, and changes in demography, impact the socio-economic conditions of rural areas such as the Achterhoek (Porru et al., 2020). For example, these conditions affect the provision of local services such as schools, shops and medical services. Also, rurality affects the improvement and development of (sustainable) public transportation. With a population spread over a large area, public 
transportation demand is low and erratic. It results in difficulties for operators and governments regarding the provision of a recurrent and widespread public transportation service (Sitanyiová \& Misso, 2019). Although demand for public transport services might be lower than urban areas, particular groups (e.g. elderly, students, disabled), still depend on transport services in rural areas (Porru et al., 2020).

\subsection{TRAVEL BEHAVIOUR IN RURAL AREAS}

In general, the choice for a particular type of transportation is determined by the distribution of activities, individual factors like income, education level, and access to activities by using an existing transport infrastructure (Geurs \& Wee, 2004). In Figure 2, all factors affecting travel behaviour from a land-use and transport perspective are shown. On the one hand, they are competing; on the other hand, all factors form a chain affecting land use and transport (Wegener \& Fürst, 1999).

Multiple actors, such as governments (public) transport operators and travellers, affect the transportation system (Wegener \& Fürst, 1999). Governments (e.g. municipality, province, national) create policies for mobility and spatial development. These policies limit transportation in a certain way. For example, one cannot drive faster than $80 \mathrm{~km} / \mathrm{h}$ with a motor vehicle on a provincial road, or a policy limits the number of busses driving during peak hours. Transport operators facilitate travel modes for public, individual, and shared transportation.

Vice versa, transportation also affects travel behaviour. When someone is travelling between location $A$ and $B$, transportation availability on both locations and transportation accessibility plays a key role. For example, when location $B$ is a job location without a nearby bus stop, and someone has access to a car, the traveller will likely choose a car above travelling by bus (Bleijenberg, 2012).

Travel behaviour may be determined based on the factors presented in the NOA-model (see Figure 3) (Vlek, Jager, \& Steg, 1997). Each individual has a particular need (e.g. shopping), opportunities (e.g. the number of shops within $15 \mathrm{~km}$ ) and abilities (e.g. access to bike and car). From this, motivation is developed by the traveller (e.g. which shop to visit) and the feasibility of actions (e.g. it is raining, so car use is preferred). Altogether, this results in particular travel behaviour.

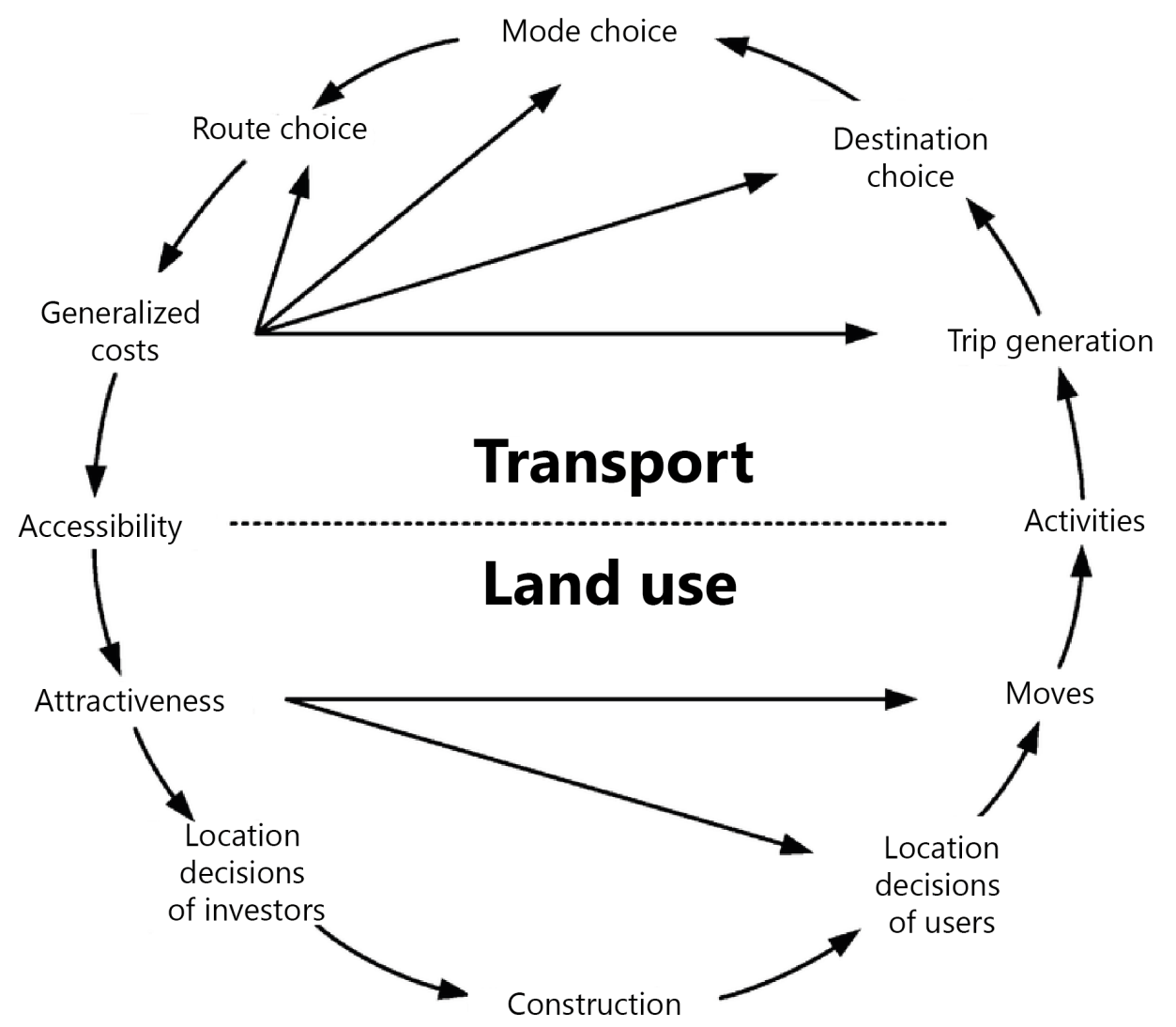

Figure 2. Transport and Land Use feedback cycle (adapted from Wegener \& Fürst (1999) 


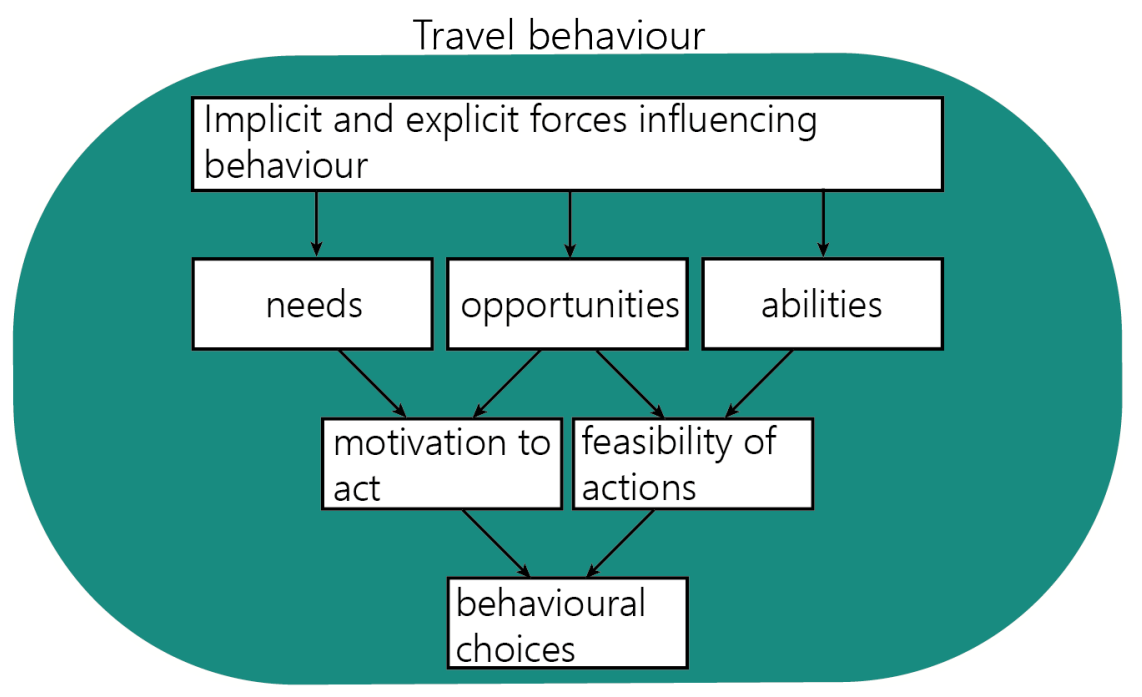

Figure 3. NOA-model. Adapted from Vlek et. al (1997)

\subsection{MOBILITY TRANSITION}

The transition towards sustainable transportation cannot be realised without large-scale changes in the current system (Farla, Alkemade, \& Suurs, 2010). As mentioned above, development of sustainable mobility is challenging due to (i) social practices and consumer behaviour, (ii) structure and organisation of the physical environments, and (iii) the variety of political lenses for reaching societal change needed to deal with climate change (Prillwitz \& Barr, 2011). The challenges with political lenses are mainly in communication, lobbying and the implementation of practices. These can be overcome by promoting partnerships between government actors, entrepreneurs, and business. Moreover, creating long-term goals and visions for sustainable mobility affect the transition towards sustainable transportation (Farla et al., 2010). However, with these partnerships, long-term societal goals and vision, an actual change of travel behaviour is not guaranteed (Barr \& Prillwitz, 2014).

As specified in the previous section (2.3), travel behaviour is determined by needs, opportunities and abilities (Vlek et al., 1997). However, it is hard to determine when someone is willing to change their travel behaviour towards sustainable mobility (Gironés \& Vrščaj, 2018). Public-private partnerships (governmentvs entrepreneurs, business)might influence travel behaviour by creating more opportunities for sustainable mobility (e.g. shared electrical cars, lower fares for zero-emission PT etcetera), but it is doubtful if this will influence each individuals' daily travel 10 patterns (Prillwitz \& Barr, 2011; Rafika, Rym, Souad, \& Youcef, 2016). The switch towards sustainable travel behaviour depends on the methods and target group used to encourage behavioural change (Gironés \& Vrščaj, 2018). When the target group and the different types of travel behaviour are identified, the specific needs, opportunities and abilities can be displayed for these travellers. For these travellers, specific incentives can be made, which will move them towards sustainable travel behaviour. Nevertheless, it will remain hard to find the right means which affects these travellers in their behaviour, since they want to travel fast and comfortable from origin to destination (Bartle \& Chatterjee, 2019; Prillwitz \& Barr, 2011)

Besides daily travel behaviour and the technical challenges of implementation of sustainable mobility, the presence of a multi-actor perspective on mobility results in an even more difficult case for implementation (Brůhová Foltýnová et al., 2020; Fagnant \& Kockelman, 2015). As mentioned above, governments, transport operators and travellers affect the transport system. Each actor has their perspective on how mobility should be like (Brůhová Foltýnová et al., 2020). For example, governments prefer to have sustainable transportation over unsustainable transportation, so that travellers' mobility is zero-emission (Bartle \& Chatterjee, 2019; Mulley \& Kronsell, 2018; Porru et al., 2020). Second, operators provide transport services, but these need to be cost-efficient and meet both government and traveller needs (Van Goevorden et al., 2006). Third, travellers want to travel fast and comfortably from origin to destination (Banister, 2008). Most travellers 
do not want to travel sustainable per se (Prillwitz \& Barr, 2011), as long as they reach their destination in time.

In practice, these perspectives need to be aligned to come to policies and practices which fit each actors' perspective (Holden et al., 2020; Scoones et al., 2015). Besides these differences in mobility perspective, there is also competition between public (e.g. bus, train) and individual transportation modes (e.g. car, bike, walking). This competition is affected by travel behaviour, opportunities and the users' demands for transportation (Barr \& Prillwitz, 2014).

Another development connected to the transition towards sustainable transportation is that of Mobilityas-a-Service (MaaS). This concept is all about demand responsive transportation and travellers needs when it comes to transport (Kamargianni et al., 2015). MaaS serves as an integral platform where travellers can book, reserve, or plan their trips easily from door to door, by offering an intermodal journey planner. With this application, all travel combination is shown for different modes like shared-car, shared-bike, carpooling, train, bus, taxi (Kamargianni et al., 2015; Nikitas, Kougias, Alyavina, \& Njoya Tchouamou, 2017). Besides showing the transport possibilities for the main travel between $A$ and $B$, also first and last mile transportation is included. This is the distance from a transport hub like a carpool location, train station or bus stop to the desired destination (Dinning \& Weisenberger, 2017). Moreover, the MaaS application includes a booking system and the possibility of paying for a single trip (Kamargianni et al., 2015).

With MaaS, social, economic and environmental benefits are possible (Nikitas et al., 2017). Lack of accessibility of opportunities can result in social exclusion and isolation. Economically, accessibility to job locations, services and shops can be improved with traveller-oriented applications like MaaS. MaaS is also labelled as environment-friendly because travellers are motivated to use (shared) public transportation instead of individual unsustainable transportation. However, in practice its' influence on travel behaviour is dependent of the set-up of the system. This will affect traffic congestion, air and noise pollution (Kamargianni et al., 2015; Lund, Kerttu, \& Koglin, 2017; Nikitas et al., 2017).

\subsection{CONCEPTUAL FRAMEWORK}

In the conceptual diagram (see Figure 4, next page), the different systems related to transportation in the Netherlands are described. As described by Milbourne \& Kitchen (2014), urban and rural areas are shaped by the pattern of movement, but even more by the "complex interplay between movement, fixity and place, as well as the everyday problematics of mobility" (p. 327).

A cyclical movement occurs between policies, travel behaviour, actors, and transportation. Each actor plays a role in the system. The policymaker works for the government and develops policies, whereas users develop an individual travel behaviour affected by these policies and their own needs, opportunities, and abilities. Operators of transportation services manage and organise the transportation system.

Governments and operators are both working on the transition towards sustainable transportation so that travellers' mobility will be sustainable. This development is affected by the environment, accessibility, transport demands, and social problems (Banister, 2008). As described before, rural areas and urban areas face challenges when sustainable transportation is developed and implemented. Spatial density is a significant influencer in this development (Dickinson et al., 2003). The spatial density of an area can be characterised by the distribution of build area (urban versus rural) and the number of opportunities for public transportation or access to transportation (Preston \& Rajé, 2007). When people are travelling, the purpose is most of the times for work, school, services like shops or for recreational purposes (Boisjoly \& ElGeneidy, 2017; Porru et al., 2020). This framework is used as a guideline to understand and explain the different concepts related to multi-actor development and implementation of sustainable mobility. In this research, not all the concepts of the conceptual framework are addressed. Only the coloured boxes are part of this research. 


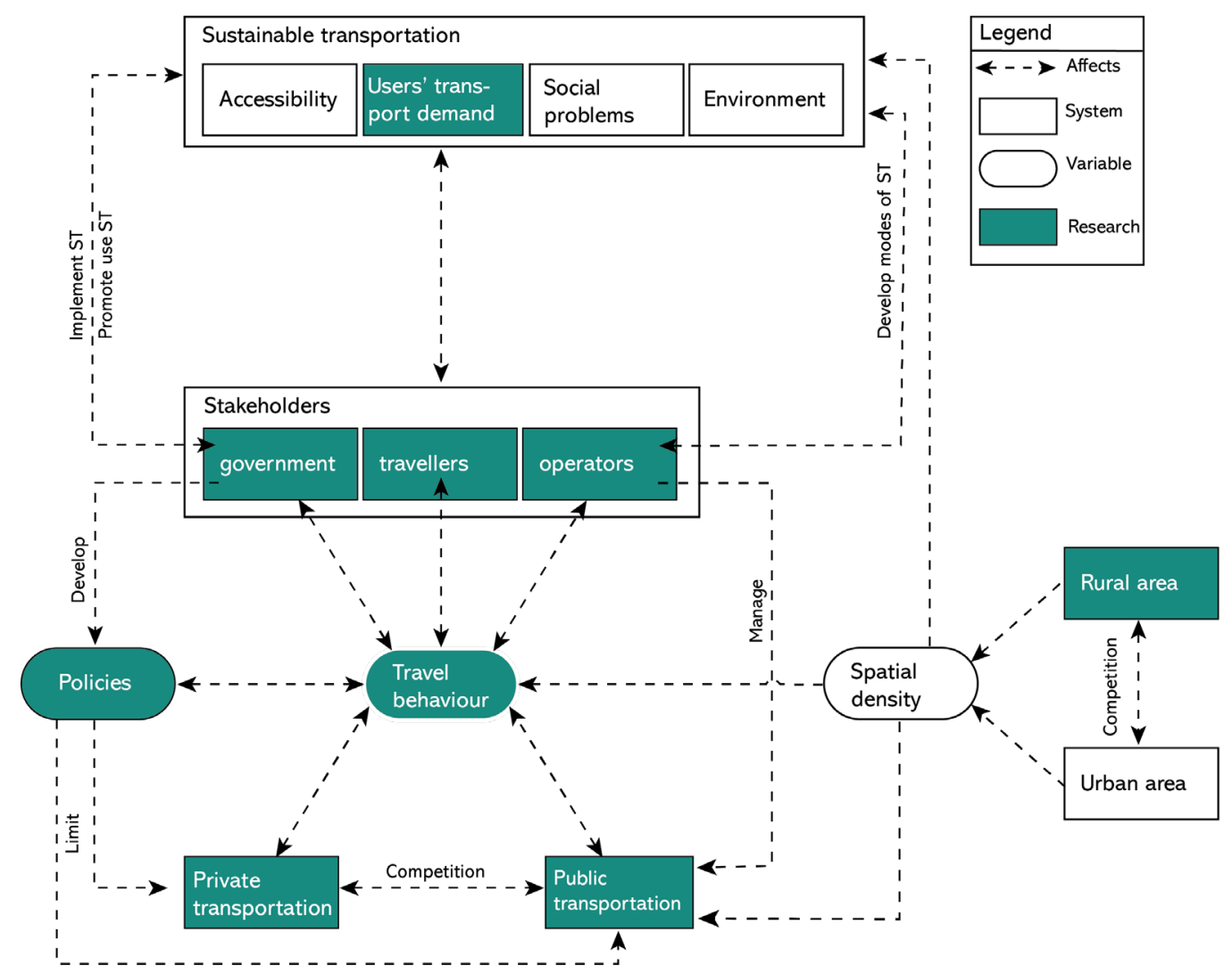

Figure 4. Conceptual framework

\subsection{CHAPTER SUMMARY}

Although there are multiple definitions of sustainable mobility, there is consensus that economic development, environmental conservation and social development are part of sustainable mobility (Banister, 2008; Jeon \& Amekudzi, 2005; Morency, 2013; Tian, Tang, Che, $\& \mathrm{Wu}, 2020$ ). Achievement of sustainability is done by the three strategies of efficiency, alteration and reduction.

In rural areas the distances between villages, cities and facilities, are in general larger when compared to urban areas. Also, accessibility to transportation services is different compared to an urban environment. It is challenging for both operators and governments to provide a public transportation network that serves all rural-oriented travellers due to its extensive spread service area, and relatively high costs (Van Goevorden, Rietveld, Koelemeijer, \& Peeters, 2006).

In general, the choice for a particular type of transportation is determined by the distribution of activities, individual factors like income, education level, and access to activities by using an existing transport infrastructure (Geurs \& Wee, 2004). Multiple 12 actors, such as governments (public) transport operators and travellers, affect the transportation system (Wegener \& Fürst, 1999). Governments (e.g. municipality, province, national) create policies for mobility and spatial development. Travel behaviour may be determined based on the factors presented in the NOA-model (Vlek, Jager, \& Steg, 1997).

The transition towards sustainable transportation cannot be realised without large-scale changes in the current system (Farla, Alkemade, \& Suurs, 2010). Concerning travel behaviour, it is hard to determine when someone is willing to change their travel behaviour towards sustainable mobility (Gironés \& Vrščaj, 2018). Public-private partnerships (government vs entrepreneurs, business) might influence travel behaviour but it is doubtful if this will influence each individuals' daily travel patterns (Prillwitz \& Barr, 2011; Rafika, Rym, Souad, \& Youcef, 2016). Besides daily travel behaviour and the technical challenges of implementation of sustainable mobility, the presence of a multi-actor perspective on mobility results in an even more difficult case for implementation (Brůhová Foltýnová et al., 2020; Fagnant \& Kockelman, 2015). 
In practice, these perspectives need to be aligned to come to policies and practices which fit each actors' perspective (Holden et al., 2020; Scoones et al., 2015). Besides these differences in mobility perspective, there is also competition between transportation modes (e.g. car, bike, walking). 



\section{METHODOLOGY}

This study is conducted in the Achterhoek, a rural area in the east of the Netherlands. Four methods are used in this research: literature and policy analysis, a survey to analyse the current thoughts of travellers in the Achterhoek, an analysis of transportation and mobility data in the Netherlands and the study area (ODiN/OViN), and in-depth interviews with actors from the study area.

\subsection{RESEARCH APPROACH}

The four methods used in this research are presented in Figure 5. These methods have been selected to conduct this research, because previous similar research proved that these methods are successful. For example, Prillwitz \& Barr (2011) showed that a comprehensive travel behaviour survey, including socio-demographic and economic characteristics of respondents, is useful in analysing travel behaviour and attitudes towards (sustainable) mobility. Moreover, Porru et al. (2020) showed that analysis of policies of governments and transport operators can help to understand the local concepts of mobility. The output of this mixed-methods approach presents a holistic view of the multi-actor perspectives. For each research sub objective, specific knowledge or information is necessary to answer the corresponding questions, ranging from scientific peer-reviewed articles to perspectives from multiple actors on sustainable mobility and transportation. In the research matrix in the Appendix, the methods are described for each research question. to identify the challenges and opportunities of the transition towards sustainable mobility in Dutch rural areas from a multi-actor perspective
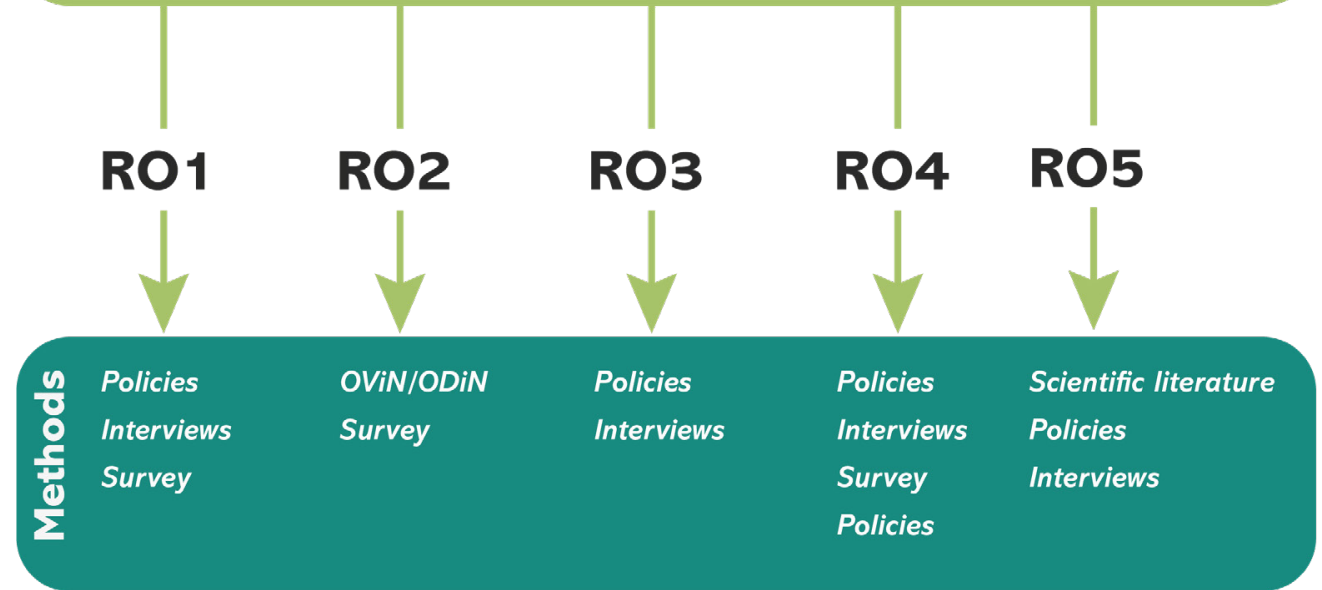

Figure 5. Methods per research objective (RO) 
The following primary and secondary data are necessary to conduct this research:

- Scientific peer-reviewed papers or books

- (International) governmental policies on multiple scales (municipality, regional, provincial, national)

- OViN/ODiN datasets (2010-2019) are used to analyse travel behaviour and the corresponding characteristics in both urban and rural areas. Characteristics are age, sex, household size, income, travel mode, travel purpose, location, and time (e.g. rush hours, weekdays, weekends)

- Survey; to analyse travel behaviour and characteristics of the rural study population

- Interview data which shows multi-actor perspectives on sustainable transportation, modal choice, current transport system, travel behaviour

- Spatial datasets show population density, population density per PC4 area, and transport infrastructure include road networks and public transport networks and stations. All this data is retrieved via the open database of CBS, Rijkswaterstaat and Province of Gelderland. For example, the data presented in maps is retrieved via these data sources.

\subsection{STUDY AREA}

The Netherlands is characterised by a diversity of urban, peri-urban and rural landscapes. As shown by Steenbekkers, Simon, Vermeij, \& Spreeuwers (2008), the Dutch government defines areas according to the number of addresses per square kilometre. One of the urban areas in the Netherlands is the Randstad. This area is characterised by a high density of people and services (e.g. shops, education, healthcare). Peri-urban areas are mostly located in the middle of the Netherlands and are characterised by a smaller population density and jobs (Steenbekkers et al., 2008). Rural areas of the Netherlands are characterised by even smaller amounts of jobs and people. Moreover, these areas are characterised by the guideline of having less than 1000 addresses per square kilometre. When areas have a density of $1000-8000$ addresses per postal code, it is characterised as (peri-)urban (see Map 1).

The Achterhoek is selected as the study area from these rural areas because it is located close to four (peri)urban areas: Foodvalley (Ede, Arnhem), Cleantech Regio (Apeldoorn, Deventer, Zutphen), Twente and 16
Map 1. Population density per squared kilometre
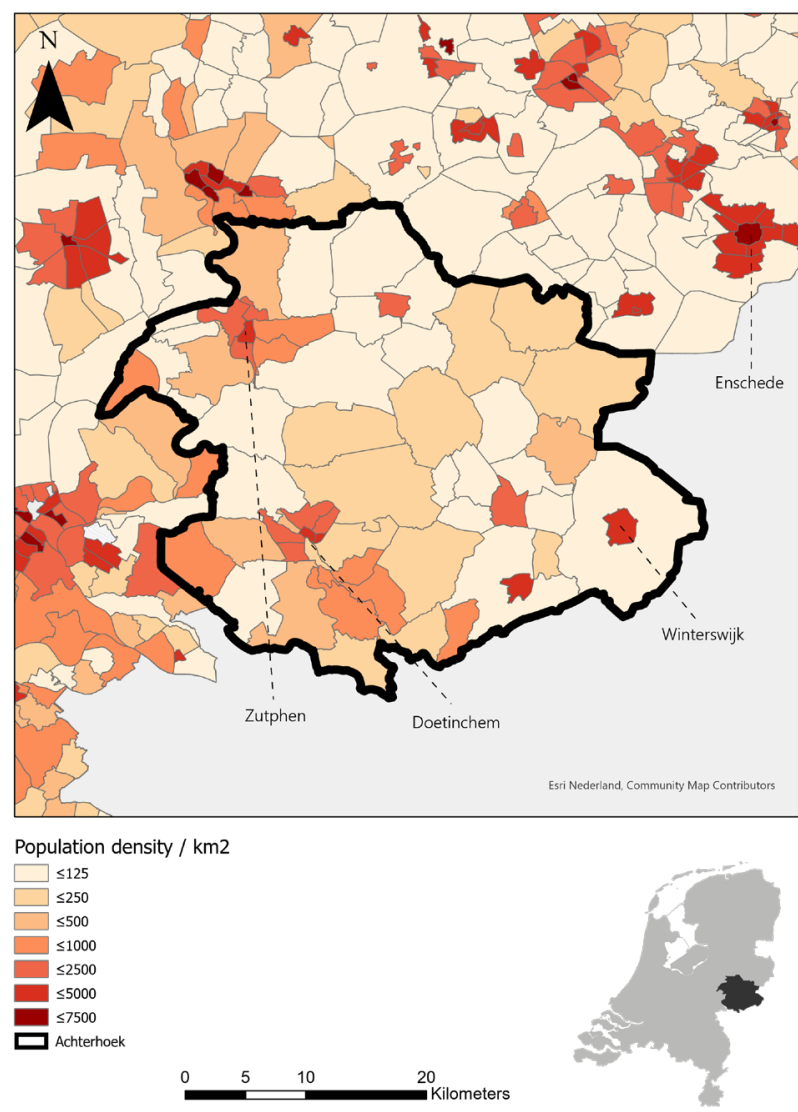

the Ruhr area across the German border.

The characteristics of the Achterhoek differ per municipality. In 2010 the urban density index showed that all the municipalities in the Achterhoek varied between "mediocre", "little", and "not urban" (CBS, 2015). Over the years, this has not changed; only Zutphen has grown into an urban area in 2019, as visible in Table 1. The population of each municipality ranges between 20.000 and 50.000 people. Only the municipality of Doetinchem has more inhabitants, nearly 60.000 (CBS, 2020d).

Table 1. Urban density index (CBS, 2020d)

\begin{tabular}{l|c|c|c} 
URBAN DENSITY INDEX & & \\
MUNICIPALITY & URBAN & & \\
\hline Aalten & & & \\
\hline Brummen & & & \\
\hline Doetinchem & & & \\
\hline Lochem & & & \\
\hline Winterswijk & & & \\
\hline Zutphen & & & \\
\hline Oude IJsselstreek & & & \\
\hline Oost Gelre & & & \\
\hline Berkelland & & & \\
\hline Bronckhorst & & & \\
\hline Montferland & & &
\end{tabular}


Car use in this area is dominant compared to travelled kilometres per public transport (CBS, 2018). The Achterhoek is located in the east of the Netherlands with $1476 \mathrm{~km}$ (see Map 1). In July 2020, the number of inhabitants is 401.477 inhabitants, with 3357 persons per PC4 area (CBS, 2020b). Within the Achterhoek, there is a variety of small cities and villages. Although the total population of the Netherlands will increase during the next 30 years, the population in the Achterhoek will be decreasing (CBS, 2019b). According to 8RHK, there are multiple challenges for the Achterhoek:

"Up to 2040, a population shrinkage of $11 \%$ is expected, and $32 \%$ will be older than 65 in 2035. Related to this are the declining labour force $(-12 \%$ up to 2030) and an expected smaller number of students in high school (-30\% in 2025) (8RHK, 2019). Moreover, the current amount of houses is not meeting future demands, and before 2030, approximately 115.000 houses need to be more sustainable". (translated from 8RHK, 2019).

The study area has one highway, the A18. All other roads are provincial or municipal roads. Carpool locations are mostly located along the A18 and close to Zutphen. There is a large network of cycling paths in the Achterhoek. The use intensity is visible in Map 3. Public transportation is arranged according to the concession managemental code. This code defines particular areas in which an operator can operate public transportation for a certain period. There is one train station in the study area connected to NS's leading train network (Zutphen) (see Map 2 and Map 5). Besides Zutphen, the NS train stations of Deventer, Dieren and Arnhem are also near the Achterhoek. The main train stations of Zutphen and Arnhem connect the NS railways network with Arriva and Blauwnet Keolis, which both operate (a part of) the local train network in the Achterhoek. Trains are operated between Arnhem - Winterswijk, Zutphen - Apeldoorn, Zutphen - Winterswijk and Zutphen Hengelo (province of Overijssel). All the buses in the Achterhoek are operated by Breng and Arriva (see Map 4). Blauwnet Keolis and Breng only facilitate small parts in the northern and western part of the Achterhoek. Arriva is the bus operator for the largest area of the Achterhoek. ZOOV organises transportation for the target audience (e.g. elderly).
Map 2. Distance to nearest (Dutch) transfer station (intercity stations, in kilometres)

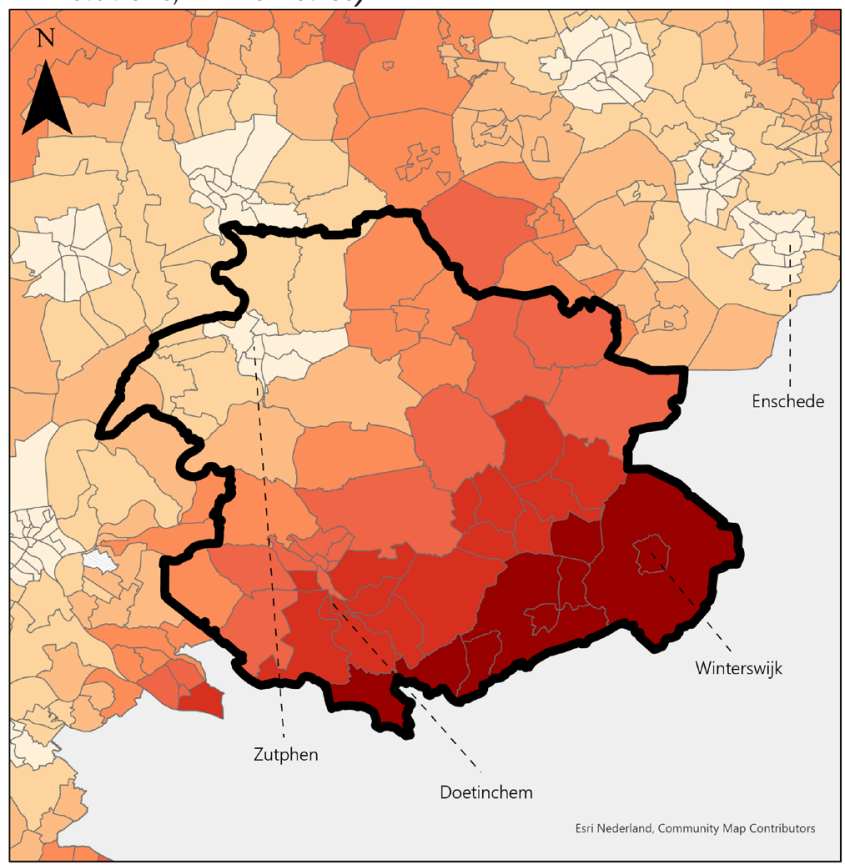

Distance to intercitystation $(\mathrm{km})$

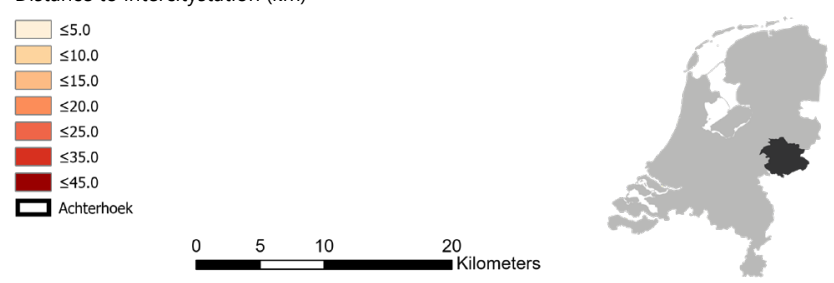

Map 3. Use intensity of bicycle network

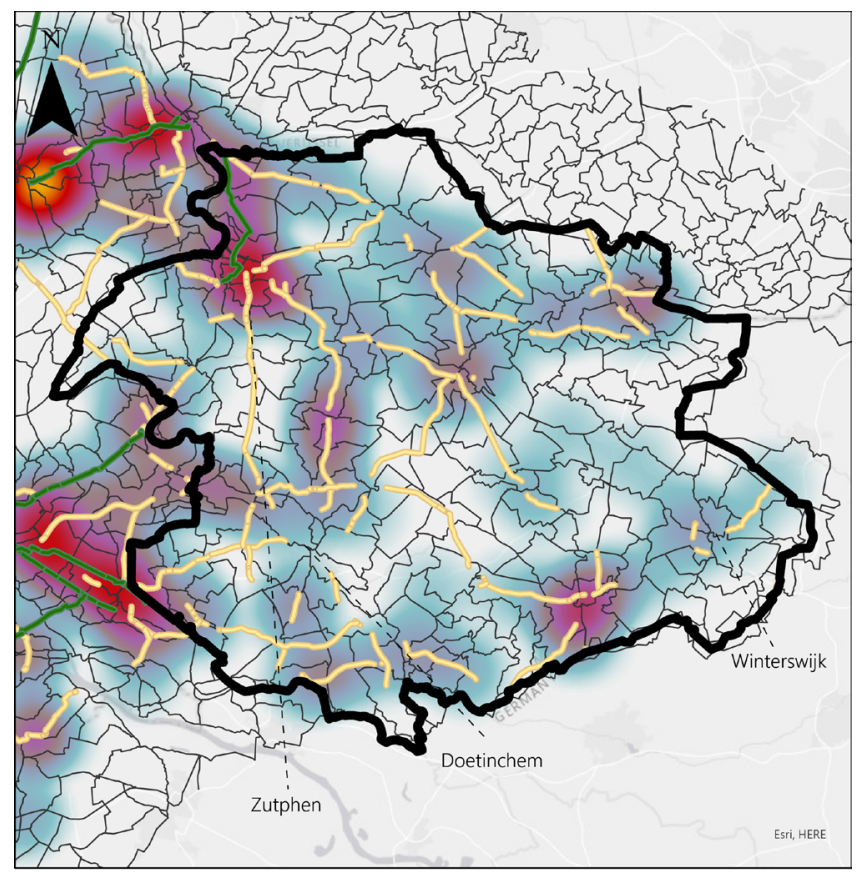

Cycling intensity main bicycle network

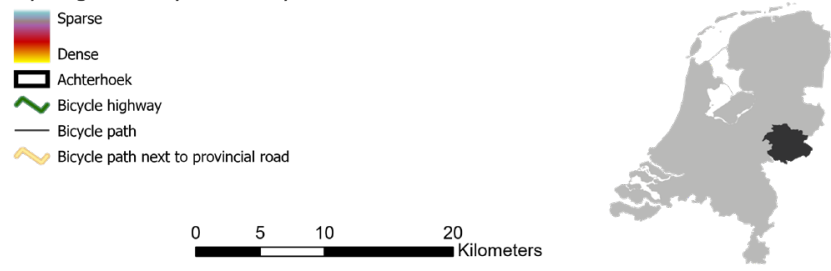


Map 4. Buslines and busstop locations in the Achterhoek

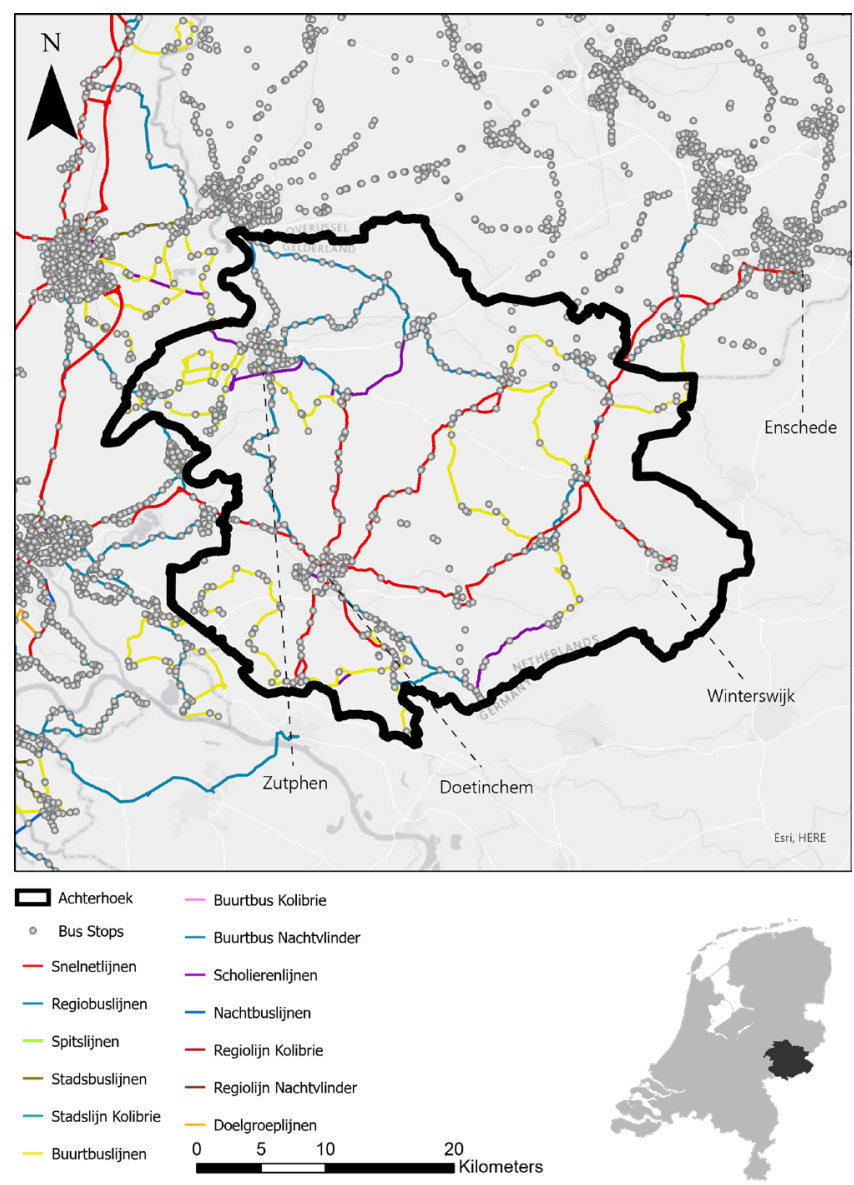

Map 5. Distance to (local) train station in kilometres
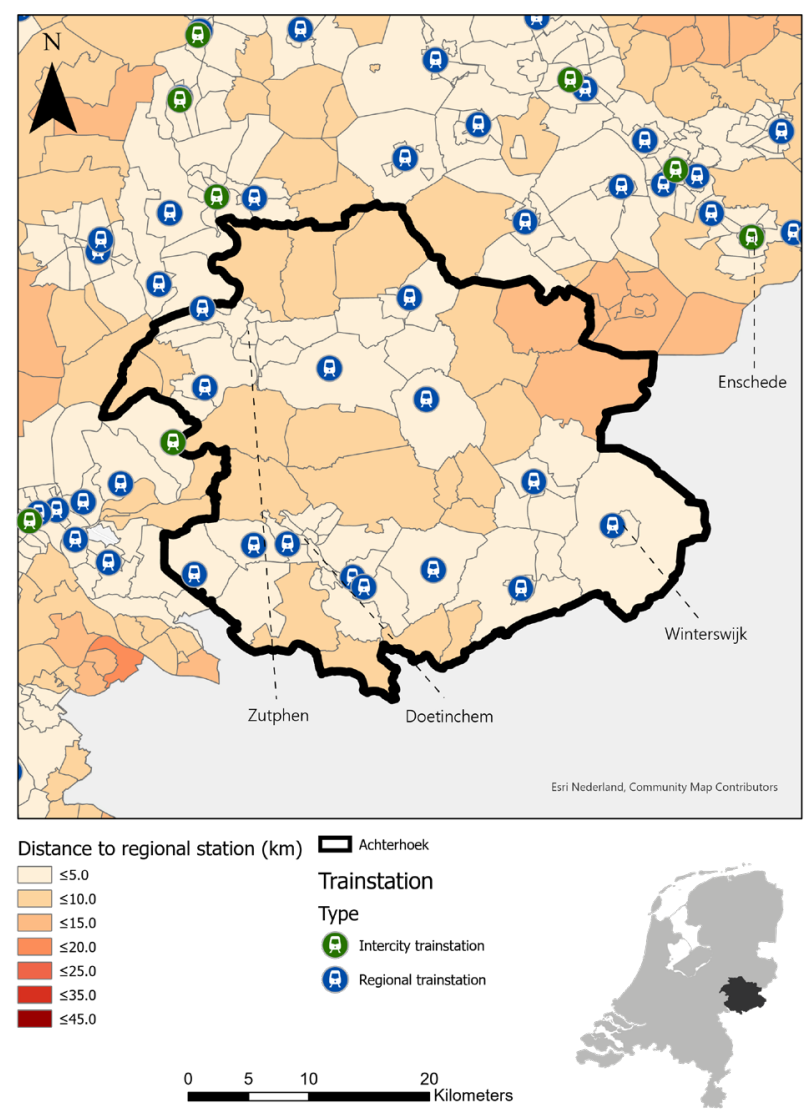

\subsection{LITERATURE AND POLICY ANALYSIS}

For literature research, literature such as peerreviewed papers, books, newspaper articles have been used. These are collected via (online) scientific libraries, like Elsevier, Scopus, and LexisNexis. Policies have been analysed to answer the research questions and analyse what has been done in the study area and the Netherlands regarding the development and implementation of sustainable transportation. Governmental policies from the national government, the province of Gelderland and 8RHK have been used for this analysis. These are collected via governmental websites. Policies or mobility plans from transport operators are collected via their websites.

Multiple articles have been analysed. The following keyword groups are used for selecting literature:

- Sustainable mobility

- Sustainable transportation

- Rural areas

- Multi-actor

- Implementation

- Development

Per group, a specification of keywords has been made to find related articles. The asterisk in the keywordgroups makes it possible only to use the base of a word. This base comes back in multiple derivations of that word. For example, Implement* results in words like implement, implementation, implemented.

An example of a keyword group is given below:

\begin{tabular}{|l|}
\hline Sustainable Transportation \\
\hline Sustainable transport* \\
\hline Sustainab* \\
\hline Transport* \\
\hline Mobilit* \\
\hline
\end{tabular}

\subsection{SURVEY}

A survey is conducted to analyse the different traveller groups. Preferred respondents for this survey are people living in the Achterhoek.

The survey started with a general question about the travel modes used. The chosen travel modes were selected, and only these could be chosen for the 
following questions about travel modes for certain distances and travel motives. The survey is used to identify the different users, their characteristics, such as age, occupation, education, daily travels (distance, mode). Next, the respondents are asked questions about sustainable transportation, modal choice, and travel behaviour for multiple distances. These distances have been chosen according to the range of daily travel behaviour. First, it is assumed that shops and education are within 5 kilometres from the respondents' house. Second, travel behaviour with distances between 5 and 15 kilometres are researched. Finally, trips longer than 20 kilometres are researched. This last distance is chosen because most travels being longer than 20 kilometres will have a destination outside the study area. For multi-modal trips, respondents needed to choose the transport mode, which bridges the longest distance in their trip. For example, when you travel to work by bike and train, the distances travelled by train are probably longer. So, the first and last miles are not included in these responses. All the specific survey questions are found in the Appendix.

Since the study area is in the Netherlands, and probably each respondent is a native Dutch speaker, the survey is in Dutch. Amongst all participants, three rewards of 50 euro are given for the shop bol.com. An award might affect people's willingness to filling in the survey.

\subsection{SAMPLING STRATEGY}

For this survey, a mixed sampling strategy has been chosen. First of all, snowball sampling has been used by sending the survey to friends, colleagues and others and asking them to forward it to people they know. A radio station in the study area has been contacted. The survey has been promoted by having a short interview on live radio about this research, and listeners were asked to fill in the survey at the radio station's website. The survey link is sent to (semi-) governments like 8RHK, the Province of Gelderland, municipalities, public transport operators Arriva and ZOOV, both operating in the study area. All the villages and cities in the study area are contacted (via Dorpsraden) to participate in the survey and forward it to their members.

Second, non-random sampling has been used. The survey link was uploaded to social media (e.g.,
Instagram). A promoted campaign has been used on Facebook and Instagram. A message has been promoted on these platforms within the preferred sample. The sample consisted of people between the age of 18 to 65 . Younger people are excluded from this sample because they cannot be part of a campaign's target population according to social media guidelines. Moreover, the campaign's target were people living in a circle of $\mathbf{2 0}$ kilometres around Bronckhorst, Lochem, Lichtenvoorde, Doetinchem, Hengelo (Gld.) and Ruurlo.

The company Moventem, where I am currently employed as a research intern, contributed to finding respondents in the Achterhoek. They contacted a panel in the study area to participate in the survey.

\subsection{IN-DEPTH INTERVIEWS}

Six in-depth interviews are held with one or two representatives of each actor, so the multiple actors' perspectives can be determined. These interviews are organised with (semi-)governments (e.g., municipality, province, or national government) and transportation operators operating in the Achterhoek. Specifically, the following actors are interviewed: 8RHK, Municipality of Bronckhorst, Province of Gelderland, Arriva, ZOOV, and a business representative participating at one of the "theme tables" (thema tafels) of 8RHK.

The users of transportation are contacted in three ways. First, in the survey, a question is posted if respondents would like to participate in an (online) interview. Second, Moventem (internship company) has many contacts with governments (provinces, municipalities) and arranged links with potential interviewees. Third, multiple actors are contacted by actively contacting them by email.

The interviews are conducted in Dutch since that is the native language of this study area's stakeholders. These interviews are transcribed in Dutch. For coding all the interviews, the researcher started with open coding. Within this process, all data is categorised, broken down, compared and analysed (Bryman, 2012). For example, an answer to a particular question is answered by all interviewees, and each part of this 
answer is categorised on specific topics. After this step, each code is again categorised or updated with specific codes (if necessary) to specify the answers per category. Relations between the text parts are made, and these are analysed. This iterative process is repeated until no extra categories or specific codes within a group can be given. The coding process is done in ATLAS.ti. The coding scheme can be found in the Appendix.

\subsection{ODIN/OVIN DATASETS}

An analysis of Onderzoek Verplaatsingen in Nederland (OViN) was required to analyse multiple travel groups and their behaviour over the past years. This research on mobility and transportation in the Netherlands shows the travel behaviour of the Dutch population. This research's output is specified for different ages, education levels, municipalities, transportation modes, travel motives, etcetera. The years 2010 to 2017 are studied in OViN research. The 2018 and 2019 datasets are retrieved from ODiN research. This research is similar to OViN but used other methods to retrieve the respondents' information and used additional variables to research mobility in the Netherlands.

Moreover, per trip, the travellers' characteristics are determined (e.g. education, occupation, the living area). The output of the data analysis of the OViN/ ODiN data is used to support the survey outcomes about the sample group as specified earlier. With both OViN/ODiN data and an additional survey, it is more likely that the stakeholder analysis presents the trends and a current view on the different groups of users and their travel behaviour.

The collection of relevant data is conducted using SPSS. The following selection criteria are used to retrieve relevant data for the Achterhoek:

- Each respondent is unique $(\mathrm{OP}=1)$

- The respondent lives in the Achterhoek area $($ COROP $=14)$

- The age of the respondent is above 16. (Leeftijd $>=16)$

For the comparison with the Randstad area, the following selection is made:

- Each respondent is unique $(\mathrm{OP}=1)$
- The respondent lives in the Randstad area (Corop $=17,19,20,21,23,25,26,27,29)$

- The age of the respondent is above 16 (Leeftijd $>=16)$.

In Table 2, the sample sizes for the Achterhoek are visible. Crosstabs are made for each year, summarising the following information about respondents characteristics (age, education, occupation), frequency of travel modes used, vehicle ownership, travel mode per distance class, travel mode per trip duration, travel motives per distance class, travel motives per trip duration, and the main transport types used.

Table 2. Sample sizes Achterhoek per OViN and ODiN dataset

\begin{tabular}{|l|l|}
\hline Year & N in Achterhoek \\
\hline 2010 & 2508 \\
\hline 2011 & 2059 \\
\hline 2012 & 2063 \\
\hline 2013 & 1986 \\
\hline 2014 & 2051 \\
\hline 2015 & 2269 \\
\hline 2016 & 2179 \\
\hline 2017 & 2122 \\
\hline 2018 & 4134 \\
\hline 2019 & 3433 \\
\hline
\end{tabular}




\subsection{CHAPTER SUMMARY}

This study is conducted in the Achterhoek, a rural area in the east of the Netherlands. Four methods are used in this research: literature and policy analysis, a survey to analyse the current thoughts of travellers in the Achterhoek, an analysis of transportation and mobility data in the Netherlands and the study area (ODiN/OViN), and in-depth interviews with actors from the study area. The figure below gives an overview of the methodological research phases.

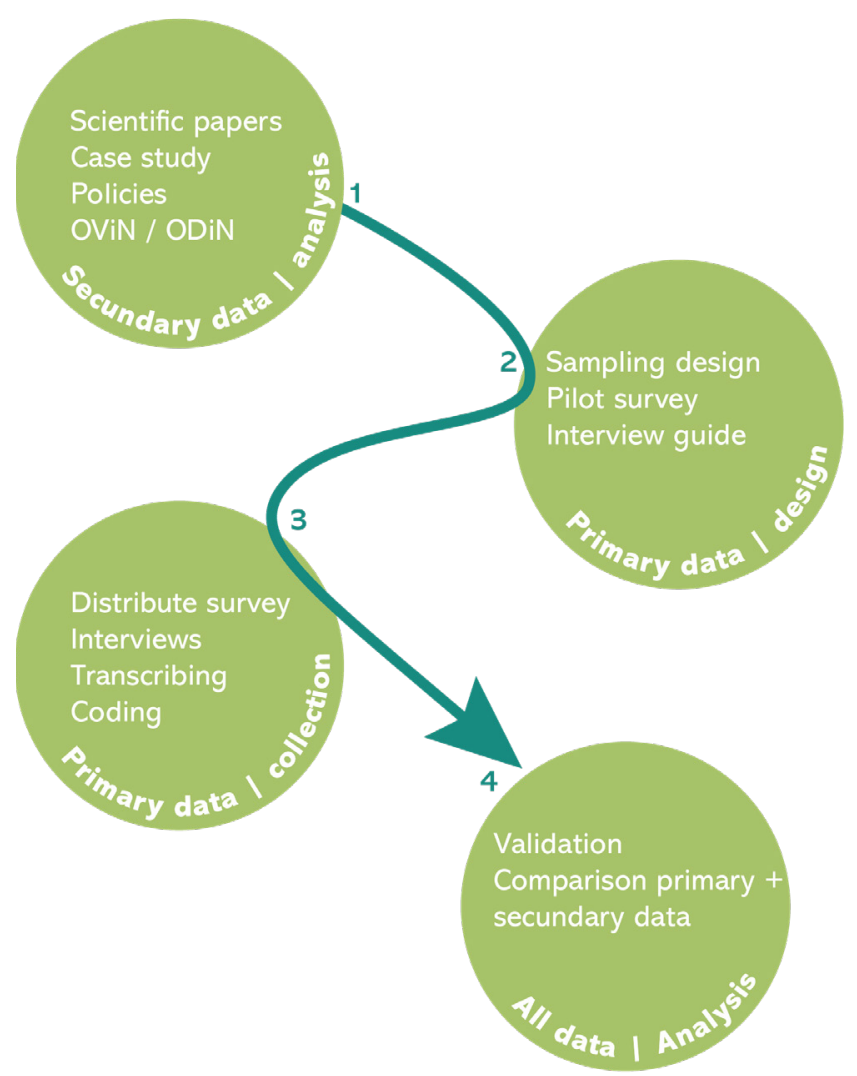

Figure 6. Methodological research phases 


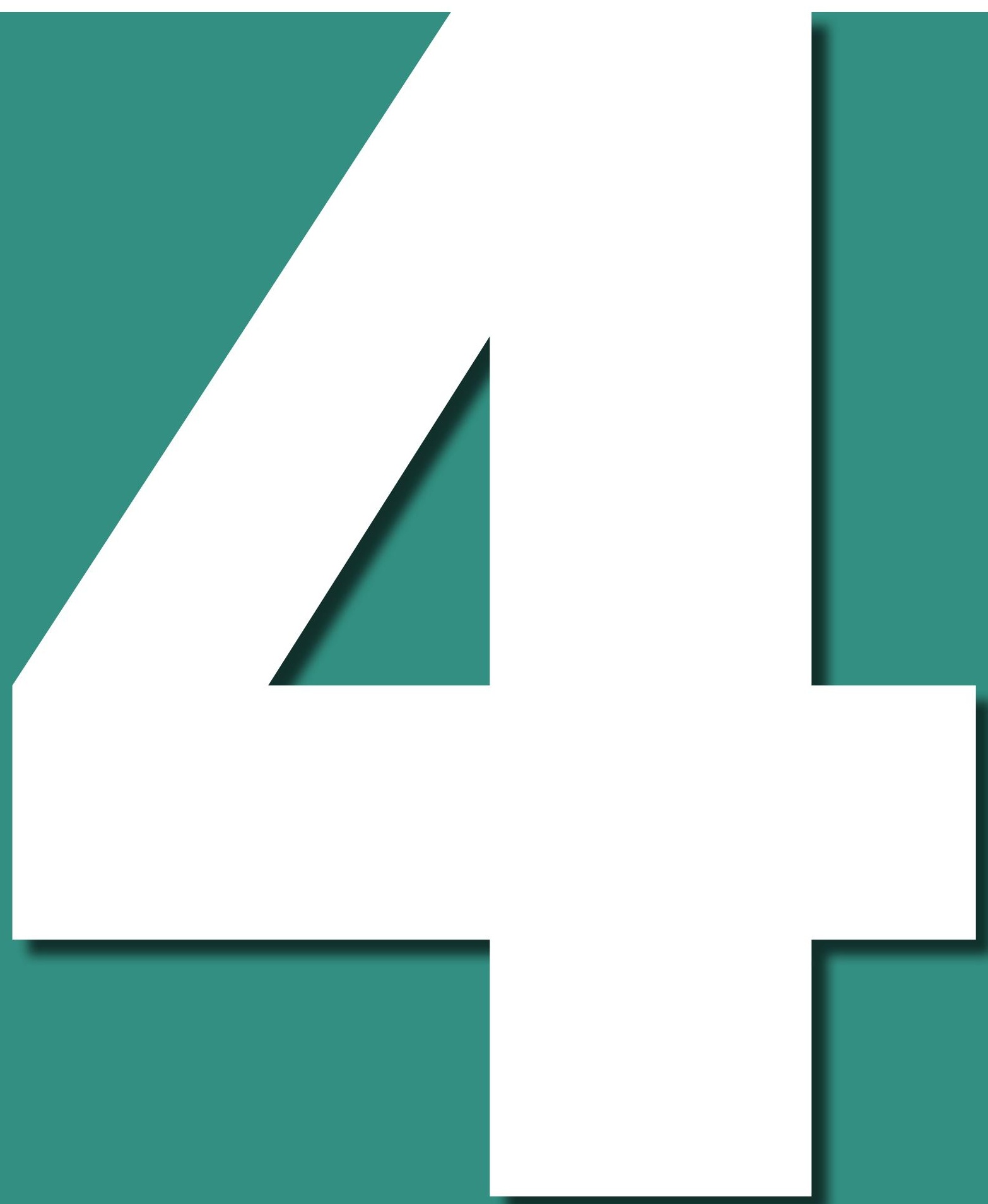




\section{RESULTS}

In this chapter, the results of the different research phases are presented. First of all, a comparison is presented between travel behaviour in the Randstad and the Achterhoek. Second, the trends of travel behaviour and car use over the past years are presented. Third, a presentation of the analysis of travel behaviour using OViN/ODiN data and the survey output ( $N=399)$. Fourth, the understanding of sustainable mobility from a multi-actor perspective is presented with the output of the interviews. That paragraph focusses on policies within the Netherlands and the study area. Lastly, the requirements for sustainable transportation and the willingness to use and implement is presented.

\subsection{TRAVEL BEHAVIOUR}

\subsubsection{Achterhoek versus Randstad}

A comparison between the Achterhoek and Randstad was done based on ODiN 2019 (CBS, 2020d). The Randstad is entirely different from the Achterhoek through population size and distribution, accessibility of services like shops, and available public transport services. The urban area is designed differently from rural areas, so cyclability and walkability are better than in rural areas.

In Figure 7 and Figure 8 (next page), it is clearly visible that travel modes used per distance class differ a lot. For the Randstad, use of public transportation, such as bus or train is higher compared to the Achterhoek. Especially for short distances up to 10 kilometres, there the usage numbers differ a lot for busses and trains. On medium range distances (10 to 40 kilometres), bus and train services are used only slightly more in the Randstad compared to Achterhoek. On long distances the use of bus and train as travel mode is similar. 
For car use, the Achterhoek has much higher usage than the Randstad. Only for short distances, similar use occurs. One explanation for lower car usage in the Randstad is that there is higher availability of other transport modes. So, there might be less necessity to travel by car. As mentioned above, the use of bus, tram and metro is much higher in the Randstad. This has also to do with the density of the network.

Besides differences, there are also similarities in usage of transport modes per distance. The use of short distance transport modes, such as walking and cycling is quite similar for all distances.

When focussing on the frequency of car use in both areas, it is interesting to see that in the Achterhoek, the percentage of people who (almost) never use a car is much lower compared to the Randstad (see Table 3). Of course, people up to the age of 18 are not permitted to drive by themselves.
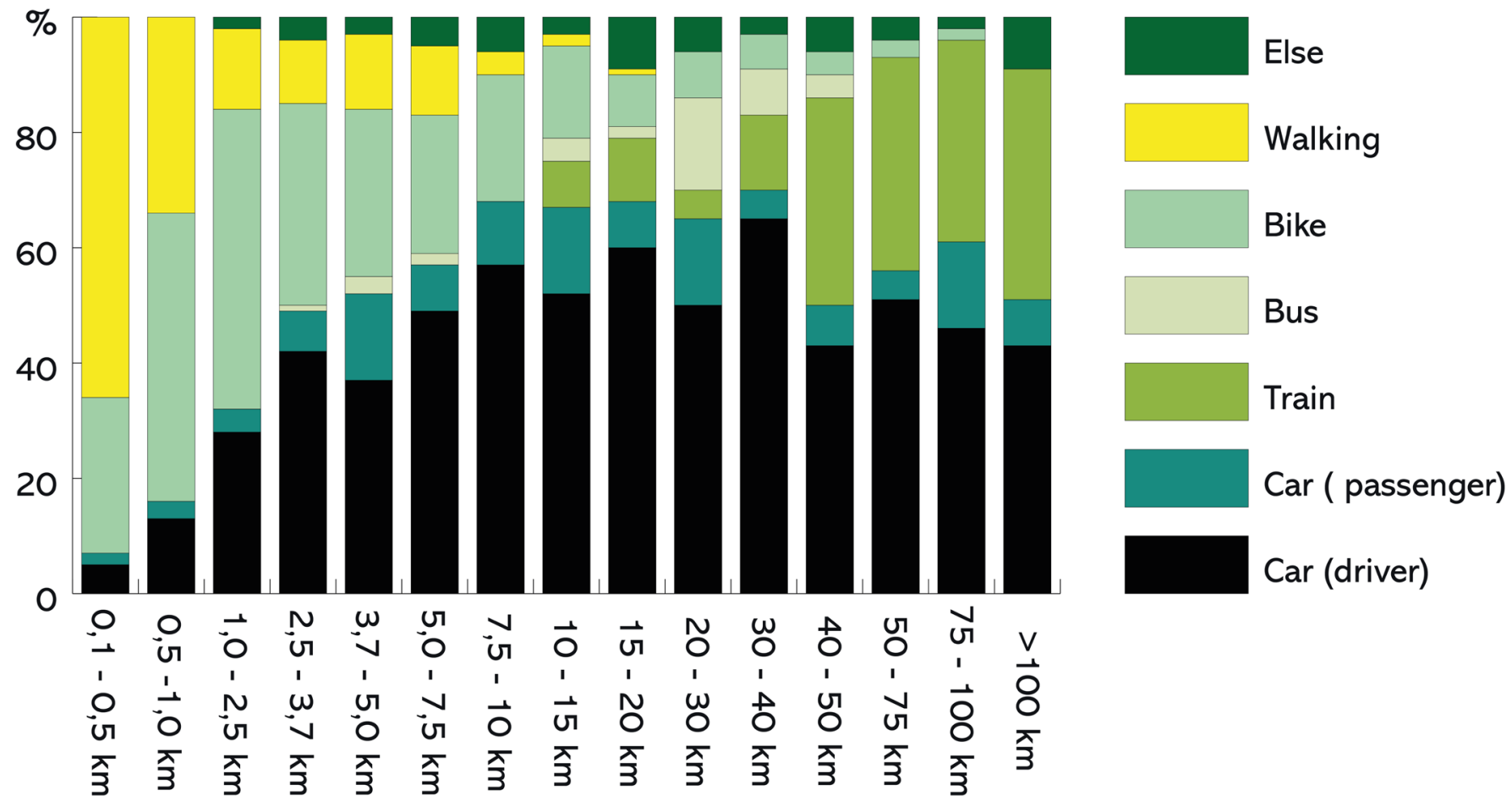

Figure 7. Transport modes per distance class used in the Achterhoek
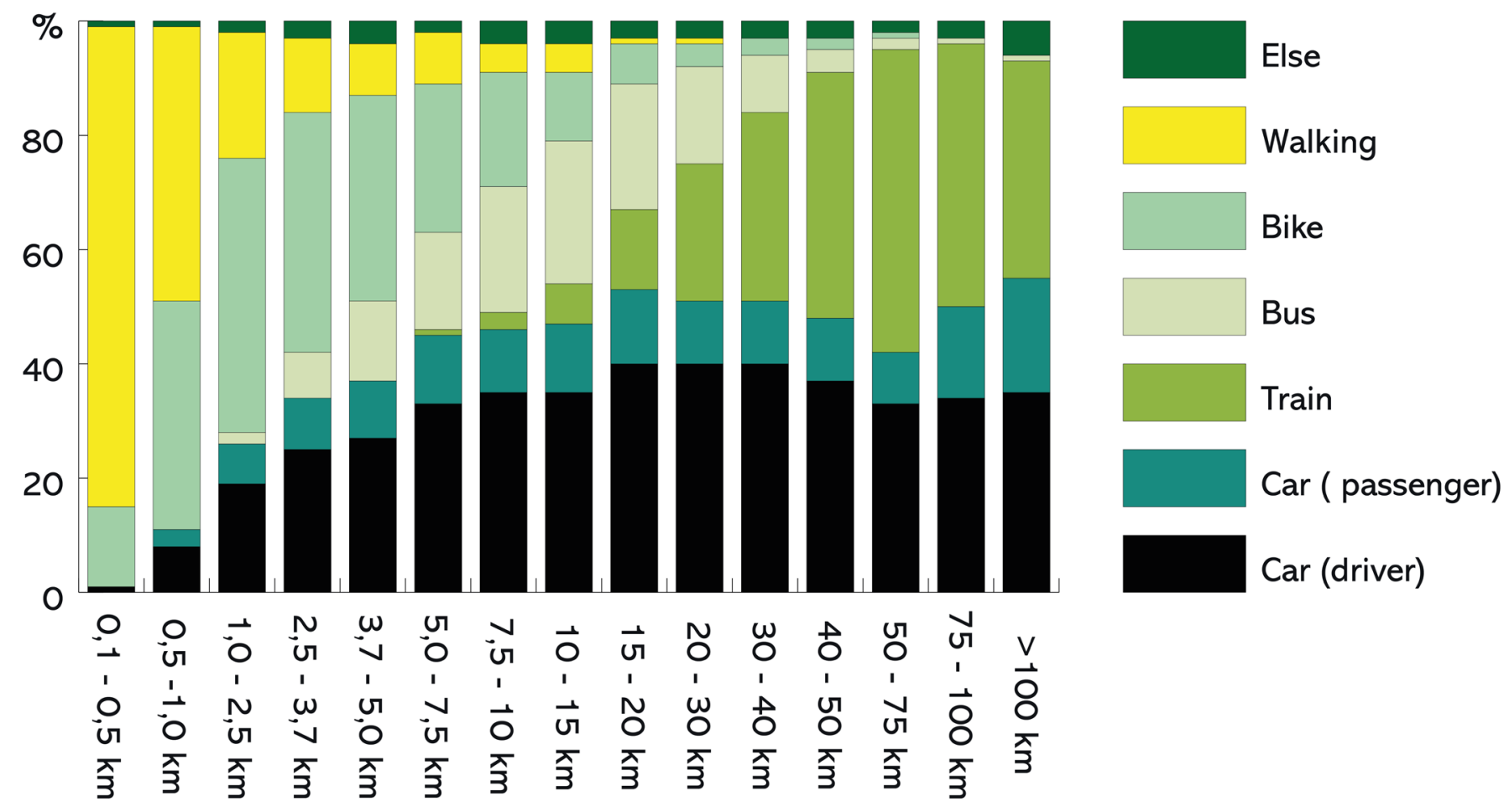

Figure 8. Transport modes per distance class used in the Randstad 
Table 3. Frequency of car use in Randstad and Achterhoek (CBS, 2019a)

\begin{tabular}{|l|c|c|c|c|}
\hline \multirow{2}{*}{} & \multicolumn{2}{c|}{ Randstad } & \multicolumn{2}{c|}{ Achterhoek } \\
& \# & $\%$ & $\#$ & $\%$ \\
\hline Daily & 22034 & 27,5 & 1547 & 45,1 \\
\hline Few times a week & 18828 & 23 & 926 & 27 \\
\hline Few times a month & 10167 & 13 & 289 & 8 \\
\hline Few times a year & 4640 & 6 & 66 & 2 \\
\hline (Almost) never & 14922 & 19 & 344 & 10 \\
\hline NA & 9651 & 12 & 261 & 8 \\
\hline Total & 80242 & 100 & 3433 & 100 \\
\hline
\end{tabular}

\subsubsection{Trends between 2010 and 2019}

In the Achterhoek, some interesting trends have occurred over the years, as visible in the next figures. First, between 2010 and 2019, the trend shows a slight increase in the number of cars per household. On the contrary, the number of households having one car decreased (see Table 4).

Second, between 2010 and 201, the trend shows a slight increase in the number of households having two or more cars. On the contrary, the number of households having one car decreased (see Table 4).

The overall use of different transport modes changed over the years. Travelling by train slightly decreased and travelling by bus remained similar (see Table 5). The number of travellers going by car as a driver slightly increased and the number of people travelling as passenger remained similar over the years. Cycling has become more popular (see Table 5). There is no difference between using a standard e-bike or speed pedelec in the OViN data. Walking as transport mode has decreased over the years.

Table 4. Number of cars per household 2010-2019, for the Achterhoek

\begin{tabular}{|c|c|c|c|c|c|c|c|c|c|c|}
\hline \multirow{2}{*}{$\begin{array}{l}\text { OViN } 2010 \text { - ODiN } \\
2019, \text { Achterhoek } \\
\% \text { household with } \\
\text { car(s) }\end{array}$} & \multicolumn{10}{|c|}{ \% Cars owned by household } \\
\hline & 웅 & ర్ & $\stackrel{N}{\sim}$ & $\frac{m}{\stackrel{m}{N}}$ & 广 & 뭉 & $\stackrel{\bullet}{\circ}$ & 숭 & $\stackrel{\infty}{\stackrel{\infty}{N}}$ & 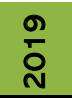 \\
\hline 0 & 7 & 5 & 6 & 8 & 9 & 9 & 8 & 8 & 7 & 7 \\
\hline 1 & 54 & 51 & 56 & 53 & 52 & 50 & 54 & 51 & 47 & 47 \\
\hline 2 & 31 & 34 & 31 & 31 & 32 & 35 & 33 & 33 & 36 & 35 \\
\hline 3 cars or more & 9 & 9 & 7 & 8 & 7 & 6 & 6 & 8 & 10 & 11 \\
\hline Total & 100 & 100 & 100 & 100 & 100 & 100 & 100 & 100 & 100 & 100 \\
\hline
\end{tabular}

Table 5. Use of transport modes between 2010 and 2019 in the Achterhoek

OViN 2010 - ODiN

2019, Achterhoek

Transport Modes (\%)

\begin{tabular}{|c|c|c|c|c|c|c|c|c|}
\hline Transport Modes & 웅 & হั) & $\stackrel{N}{\stackrel{N}{N}}$ & $\frac{m}{\delta}$ & ষ্ণ & 뭉 & $\frac{0}{\mathrm{~N}}$ & $\frac{N}{i}$ \\
\hline Car as driver & 43 & 43 & 45 & 43 & 44 & 44 & 43 & 44 \\
\hline Car as passenger & 11 & 11 & 7 & 11 & 8 & 9 & 10 & 11 \\
\hline Train & 4 & 3 & 2 & 3 & 3 & 2 & 2 & 2 \\
\hline Bus/tram/metro & 1 & 1 & 1 & 1 & 1 & 2 & 1 & 1 \\
\hline Moped/Scooter* & 1 & 1 & 1 & 1 & 1 & 0 & 1 & 0 \\
\hline Bike and E-bike & 26 & 3 & 32 & 29 & 133 & 28 & 32 & 3 \\
\hline Walking & 14 & 9 & 10 & 12 & 8 & 12 & 11 & 10 \\
\hline Else & 2 & 2 & 2 & 1 & 2 & 3 & 1 & 2 \\
\hline Total & 100 & 100 & 100 & 100 & 100 & 100 & 100 & 100 \\
\hline
\end{tabular}




\subsubsection{Sample characteristics}

The respondents' characteristics and distribution over age groups differ between the survey output and the used ODiN dataset of 2019.

The survey has been filled out by 429 respondents, where 399 outputs were included in the final output and analysis. In Map 6, the dispersion of respondents over the study area is visible. The filter, correction and coding rules of the survey output are found in the Appendix. The ODiN dataset of the Achterhoek has 3433 useful entries.

The respondents of the ODiN sample are distributed according to the actual age distribution of the Achterhoek. The survey output is not distributed corresponding to the actual age distribution. Only the ages 25-29 and 55-59 of the sample population are represented equally (see Table 6). So, the survey output can only be used to make conclusions for the population as a whole.

As visible in Table 6, most of the respondents in both samples finished middle education (HAVO, VWO or $\mathrm{MBO}$ ) and higher education (HBO, WO). Just a small group finished (only) lower education (VMBO, MAVO, LTS or huishoudschool).

Moreover, Table 6 shows that most of the respondents of the survey (46\%) are employed (loondienst). For the ODiN sample, occupation of the respondents varied between working 12-30 hours/week (18\%), working $>30$ hours/week (36\%), own household (3\%), student $(15 \%)$, unemployed $(2 \%)$, incapacitated $(2 \%)$, retired (19\%), other $(5 \%)$. From the respondents working $>30$ hours per week, $58 \%$ owned a car. $11.5 \%$ of these respondents owned two cars. For all movements

Table 6. Characteristics of sample population of survey and ODiN

\begin{tabular}{|c|c|c|c|}
\hline Variables & Classes & Survey $N=399$ (\%) & ODiN $2019 \mathrm{~N}=3433(\%)$ \\
\hline \multirow[t]{2}{*}{ Gender } & Men & 49,1 & 49,3 \\
\hline & Women & 50,9 & 50,7 \\
\hline \multirow[t]{15}{*}{ Age } & $15-17$ & 0,5 & 5,2 \\
\hline & $18-19$ & 2,0 & 4,1 \\
\hline & $20-24$ & 4,3 & 4,7 \\
\hline & $25-29$ & 5,8 & 5,9 \\
\hline & $30-34$ & 4,8 & 6,1 \\
\hline & $35-39$ & 4,0 & 6,6 \\
\hline & $40-44$ & 7,3 & 6,4 \\
\hline & $45-49$ & 7,0 & 10,1 \\
\hline & $50-54$ & 6,5 & 10,6 \\
\hline & $55-59$ & 10,3 & 8,1 \\
\hline & $60-64$ & 14,3 & 7,2 \\
\hline & $65-69$ & 12,6 & 7,6 \\
\hline & $70-74$ & 11,8 & 4,1 \\
\hline & $75-79$ & 7,5 & 4,4 \\
\hline & $>80$ & 1,8 & 4,3 \\
\hline \multirow[t]{5}{*}{ Education } & Primary education & 1,8 & 4,1 \\
\hline & Lower education & 12,5 & 16,9 \\
\hline & Middle education & 43,6 & 37,8 \\
\hline & Higher education & 42,1 & 34,1 \\
\hline & Else & 0,0 & 5,5 \\
\hline \multirow[t]{7}{*}{ Occupation } & Student & 6,3 & 15,3 \\
\hline & Paid employment & 46,1 & 54,5 \\
\hline & Self-employed & 4,5 & n.a. \\
\hline & Unemployed & 6,3 & 1,7 \\
\hline & Incapacitated & 6,0 & 2,0 \\
\hline & Retired & 29,8 & 18,8 \\
\hline & Else & 1,0 & 7,7 \\
\hline \multirow[t]{4}{*}{ Cars } & no cars & 14,3 & 6,6 \\
\hline & 1 car & 53,1 & 46,8 \\
\hline & 2 cars & 29,3 & 35,4 \\
\hline & 3 or more cars & 3,3 & 11,2 \\
\hline
\end{tabular}


in the Achterhoek is the car, the dominant transport mode, as visible in Table 7 (page 30) (CBS, 2020d). In the survey population, $76 \%$ of all respondents own a car, and 5\% leases a car. Moreover, the respondents are asked how many cars there are within their household. These numbers differ a bit with the numbers which are seen in the results of ODiN (Table 6).

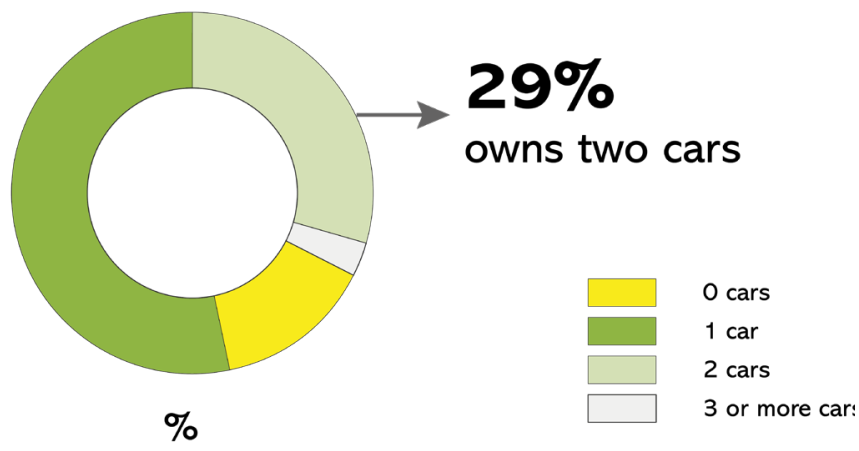

Figure 9. Car ownership

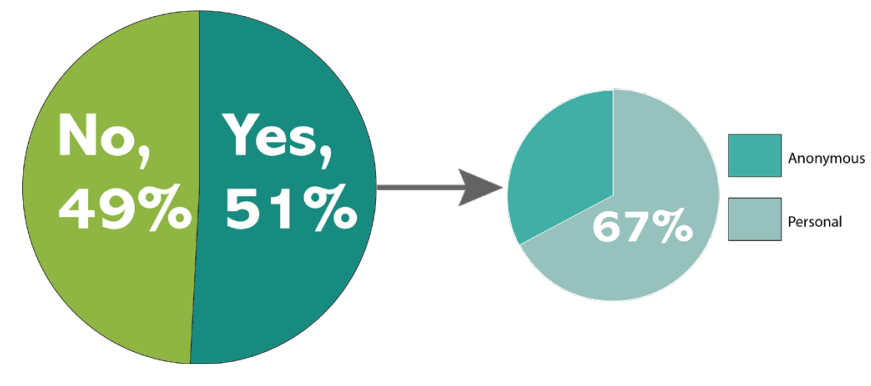

Figure 10. Do you have an OV - card?

N 30 N Map 6. Number of respondents per PC4 area
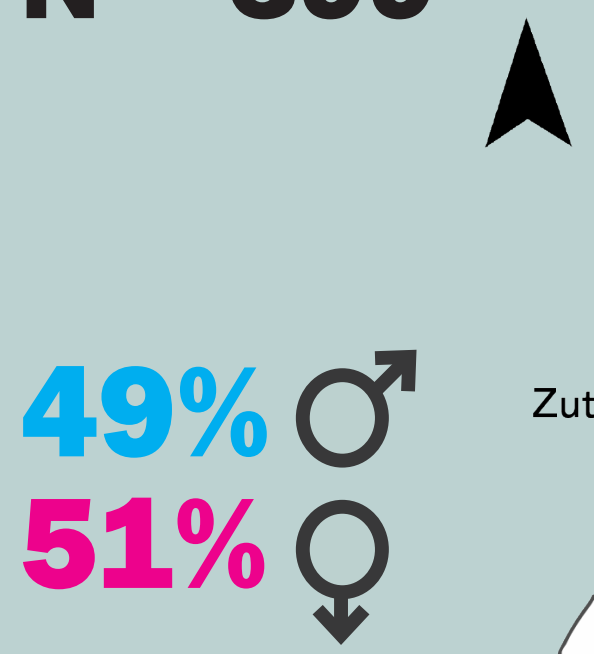

youngest $=16$ average $=54$ oldest $=\mathbf{8 7}$
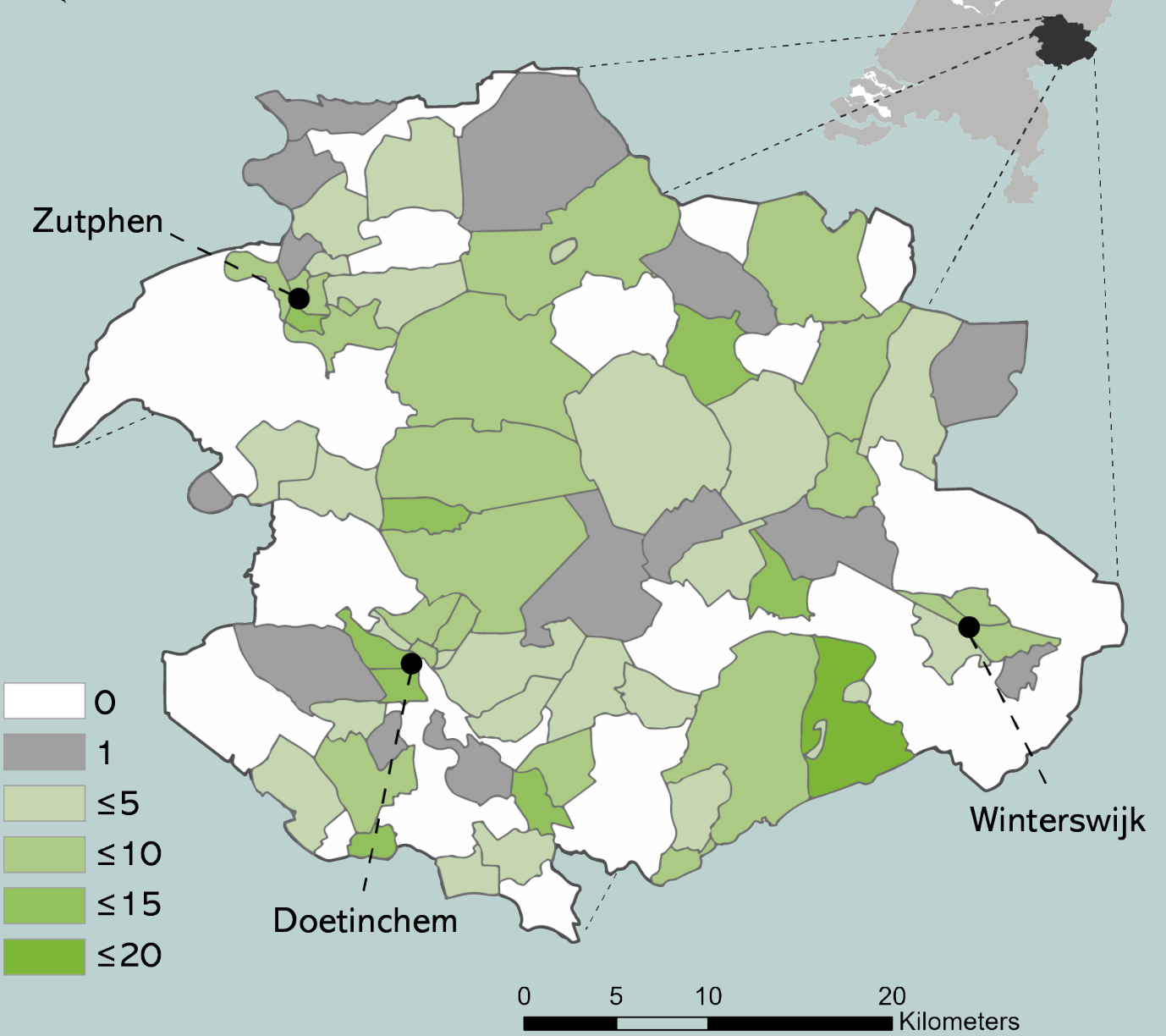


\subsubsection{Travel motives}

Per travel motive, multiple travel modes are used, as visible in Table 7. For the ODiN sample, the car is used the most for each motive, except for travelling for education or recreational purpose. Likely, the car is not that dominant for travels from and to education, because most of the respondents travelling for education will be young and might not all have their car. Moreover, when travelling for education, respondents will probably be young and have an OV-card with a student rate to travel for free or with a discount on public transportation. Travelling by bus in mostly used for education or services. People are travelling by train mostly from and to work, business and education. Cycling is a common travel mode for all travel motives, except business. This is similar for walking.

This is similar for the survey, where the most used travel modes per motive and distance are identified, as displayed in Table 8, Table 9 and Table 10. In general, the car is dominant for multiple travel motives and multiple distances. . The bus is not often used by the respondents for multiple travel motives. The bus is mostly used for trips to education. The train is used more, compared to travelling by bus. Most of the respondents travel by train for education, business or from and to work. Cycling (including e-bike and speed pedelec) is a popular transport modes up to 15 kilometres, for all travel motives (see Table 9). For longer distances, cycling is only used often for recreational purposes. Walking is only measured for trips up to 5 kilometres. It is a popular transport mode for all motives except, from and to work, business and education. This is likely, because job locations, and schools might be located further away than 5 kilometres.

\subsubsection{Most used travel modes}

In Figure 11, the most used transport modes are displayed per distance. For example, for mode car (owner) the three bars represent the number of respondents who use the car most for the three distances. Empty bars mean that a particular transport mode is not chosen as most used transport mode for that distance.

For travels up to 5 kilometres, the most used transport mode is a bike (see Figure 11), because it is healthy $(28 \%)$, easy (23\%) and cheap (19\%) (see Figure 13). The second most used transport mode for $5 \mathrm{~km}$ is the car. The respondents $(\mathrm{N}=100)$ motivate their choice by responding that it is easy (52\%) and fast (32\%). $20 \%$ of the respondents use an e-bike the most for travels up to 5 kilometres. The motivation of these

Table 7. Travel motives per transport mode for ODiN 2019 Achterhoek

\begin{tabular}{l|c|c|c|c|c|c|c|}
$\begin{array}{l}\text { ODiN 2019, Achterhoek } \\
\text { Motive }\end{array}$ & \multicolumn{7}{c}{ Transport modes (\%) } \\
\hline From and to work & 55 & 11 & 2 & 23 & 2 & 5 & 100 \\
\hline Business & 78 & 10 & & 6 & & 5 & 100 \\
\hline Education & 9 & 25 & 16 & 39 & 2 & 2 & 100 \\
\hline Services & 36 & & 4 & 32 & 6 & & 100 \\
\hline Shopping & 47 & 1 & 1 & 32 & 10 & 0 & 100 \\
\hline Bringing / picking up kids & 61 & & & 20 & 12 & 1 & 100 \\
\hline Social & 45 & 6 & & 24 & 9 & 2 & 100 \\
\hline Recreational & 35 & 3 & & 38 & 12 & 2 & 100 \\
\hline
\end{tabular}


Table 8. Travel motives per transport mode for travels up to 5 kilometres (survey output)

Survey $(\%)$

Transport modes (\%)

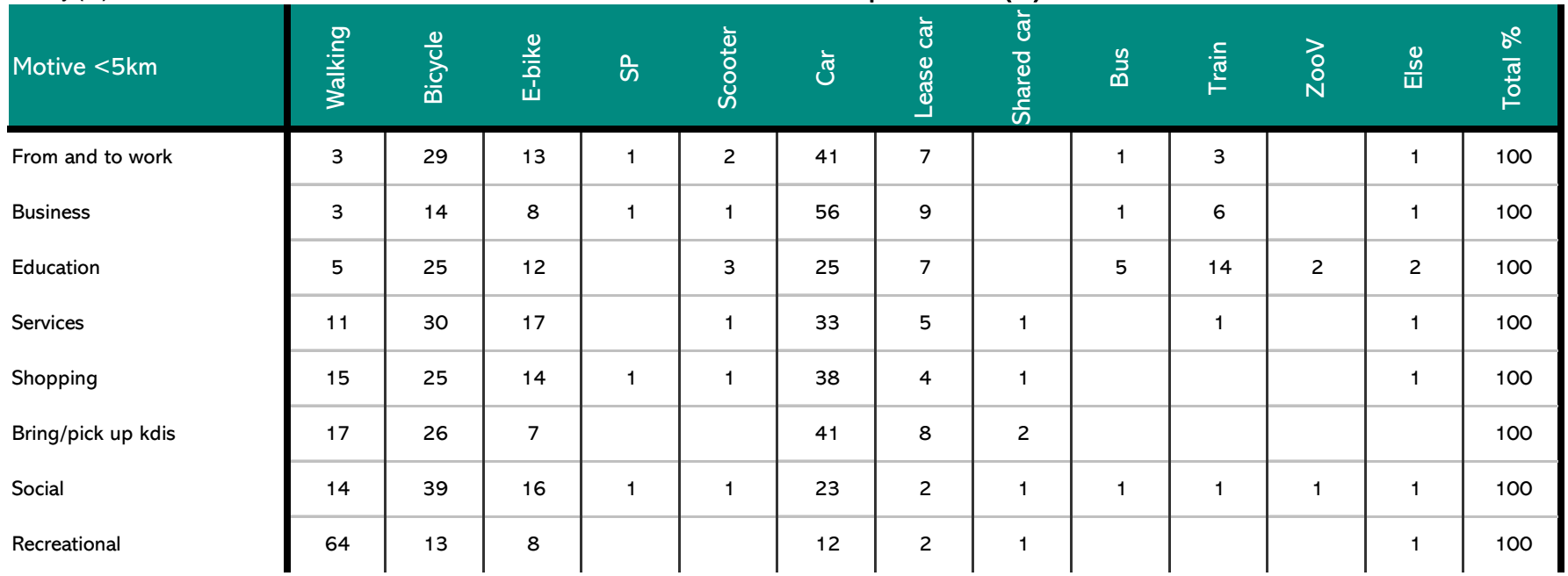

$S P=$ speed pedelec

Table 9. Travel motives per transport mode for travels between 5 and 15 kilometres (survey output)

Survey (\%)

Transport modes (\%)

\begin{tabular}{|c|c|c|c|c|c|c|c|c|c|c|c|c|}
\hline Motive $5-15 \mathrm{~km}$ & $\frac{\frac{d}{U}}{\frac{J}{0}}$ & $\begin{array}{l}\frac{0}{\frac{0}{0}} \\
\frac{1}{1}\end{array}$ & के & $\begin{array}{l}\frac{1}{d} \\
\text { ○े } \\
\text { ठ } \\
\text { ஸे }\end{array}$ & ठె & 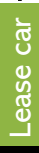 & $\begin{array}{l}\frac{1}{8} \\
\frac{8}{0} \\
\frac{d}{d} \\
\frac{d}{4}\end{array}$ & $\stackrel{n}{\vec{c}}$ & $\frac{\text { 들 }}{\text { 든 }}$ & $\begin{array}{l}\text { Oे } \\
\text { O }\end{array}$ & 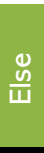 & $\frac{\stackrel{0}{0}}{\frac{\pi}{0}}$ \\
\hline From and to work & 13 & 10 & 1 & 2 & 58 & 7 & 1 & 2 & 6 & & & 100 \\
\hline Business & 3 & 8 & 1 & 1 & 68 & 9 & 1 & 2 & 6 & & & 100 \\
\hline Education & 13 & 11 & 2 & 3 & 34 & 8 & 2 & 7 & 16 & 2 & 2 & 100 \\
\hline Services & 18 & 15 & 1 & & 55 & 7 & 1 & 2 & 2 & & & 100 \\
\hline Shopping & 16 & 13 & 1 & 1 & 59 & 6 & 1 & 1 & 1 & 1 & & 100 \\
\hline Bring/pick up kdis & 15 & 7 & 1 & & 64 & 9 & 2 & & & & 1 & 100 \\
\hline Social & 26 & 17 & 1 & 1 & 44 & 5 & 1 & 2 & 3 & & 1 & 100 \\
\hline Recreational & 37 & 18 & & 2 & 34 & 5 & 2 & & 1 & & & 100 \\
\hline
\end{tabular}

Table 10.

Travel motives per transport mode for travels longer than 20 kilometres (survey output)

Survey (\%)

Transport modes (\%)

\begin{tabular}{|c|c|c|c|c|c|c|c|c|c|c|c|c|}
\hline Motive $>20 \mathrm{~km}$ & $\frac{\frac{0}{U}}{\frac{\widehat{U}}{0}}$ & 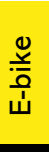 & nे & $\begin{array}{l}\text { ঠे } \\
\text { ثั० } \\
\text { ठ } \\
\text { ஸे }\end{array}$ & ঠ் & 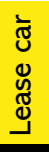 & 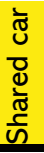 & $\stackrel{n}{D}$ & . & $\begin{array}{l}> \\
\text { O } \\
\text { N }\end{array}$ & $\frac{\triangleq}{\mathscr{W}}$ & $\frac{50}{\frac{5}{0}}$ \\
\hline From and to work & 2 & 4 & 1 & 1 & 67 & 11 & & 1 & 13 & & 1 & 100 \\
\hline Business & 1 & 1 & 1 & & 68 & 13 & 1 & 1 & 14 & & 1 & 100 \\
\hline Services & 2 & 4 & & 2 & 73 & 8 & 1 & 1 & 8 & 1 & 1 & 100 \\
\hline Shopping & 2 & 5 & & 1 & 74 & 8 & 1 & 2 & 6 & & 1 & 100 \\
\hline Bring/pick up kdis & 6 & 6 & & 1 & 75 & 6 & & 1 & 4 & & 1 & 100 \\
\hline Social & 7 & 6 & & 1 & 64 & 7 & 1 & 2 & 11 & 1 & 1 & 100 \\
\hline Recreational & 14 & 12 & & 1 & 56 & 7 & 1 & 1 & 5 & 1 & 2 & 100 \\
\hline
\end{tabular}

Recreational 
respondents $(\mathrm{N}=78)$ is that it is healthy (29\%), easy (24\%) and better for the environment (18\%). Walking is the most used transport mode up to 5 kilometres for $10 \%$ per cent of the respondents. These respondents $(\mathrm{N}=39)$ use this transport mode the most since it is healthy (42\%), easy (28\%) and cheap (17\%).

The most used transport modes for distances between 5 and 15 kilometres are car (56\%), bicycle (12\%) and e-bike (12\%) (see Figure 11). The motivation they give for using a car $(\mathrm{N}=222)$ the most is because it is easy (46\%), fast (42\%) and because they can travel together (6\%) (see Figure 13). The bicycle $(\mathrm{N}=48)$ is most used because it is healthy (28\%), it is better for the environment (22\%) and cheap (20\%). For the e-bike $(\mathrm{N}=48)$, the respondents say that it is healthy
(28\%), easy (24\%) and cheap (17\%).

For travels longer than 20 kilometres, respondents answered that they travel mostly by car (68\%), train (11\%) and lease car (7\%) (see Figure 11). Also, $7 \%$ of the respondents answered that they never travel distances longer than 20 kilometres. They motivate to use these transport modes the most are for a car $(N=271)$ that it is easy $(42 \%)$ and fast $(41 \%)$ (see Figure 13). For respondents travelling by train $(\mathrm{N}=42)$, the ease of travelling (28\%) and fastness (22\%) are reasons for choosing this transport mode the most for travels longer than 20 kilometres. The lease car $(\mathrm{N}=29)$ is used the most because it is easy $(41 \%)$, fast (35\% and cheap (18\%).

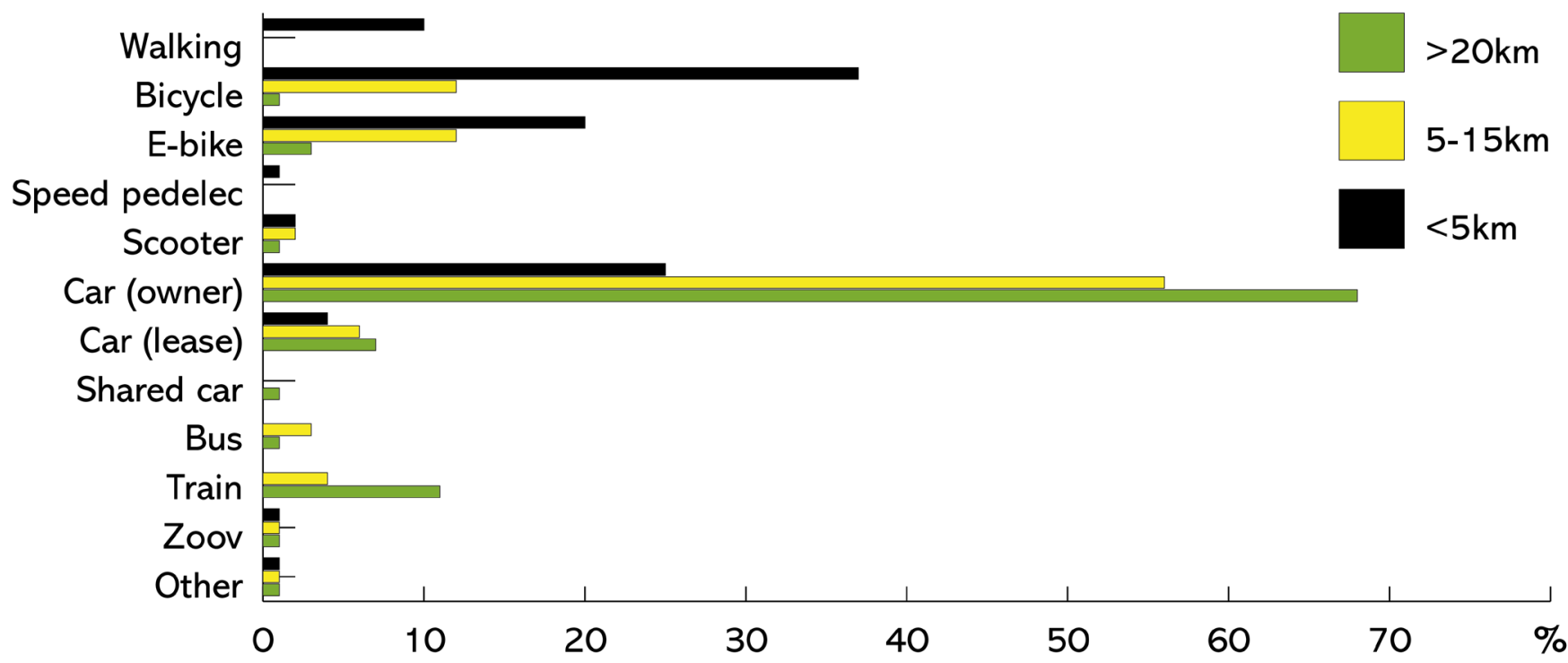

Figure 11. Most used transport modes per distance class (survey output)

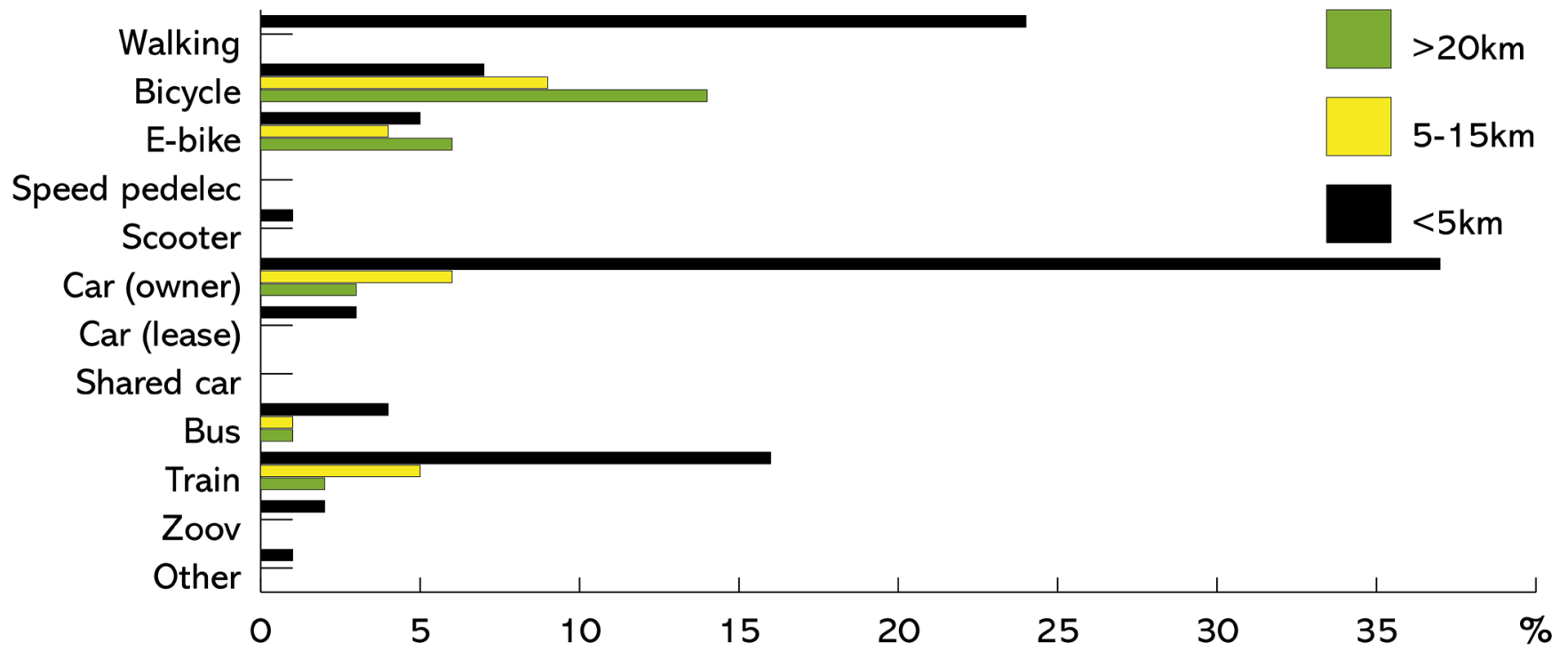

Figure 12. Least used transport modes per distance class (survey output) 

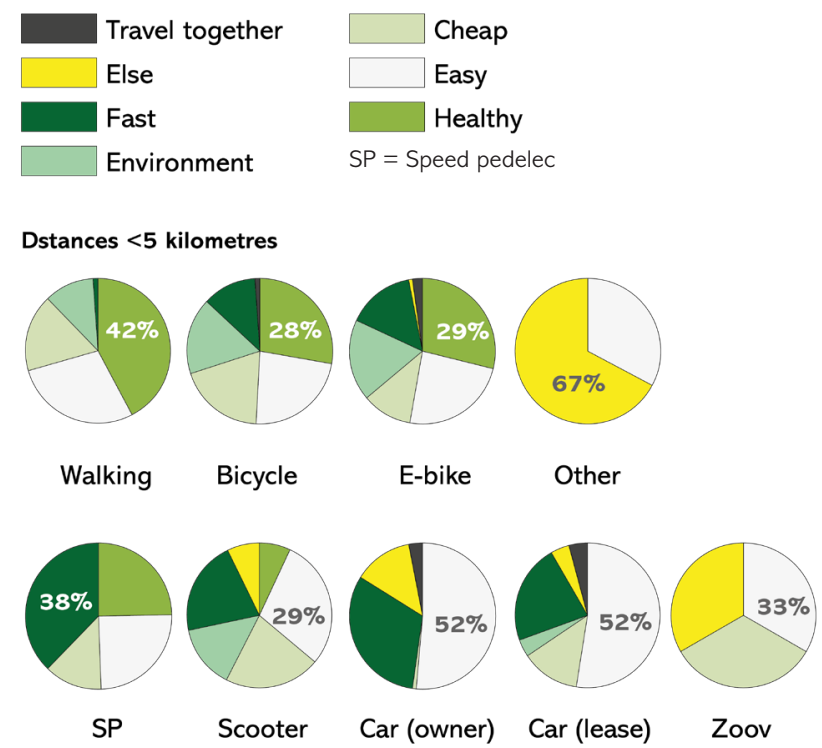

Distances between 5 - 15 kilometres
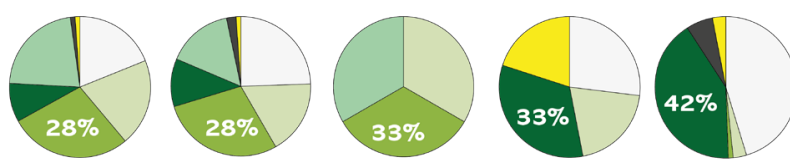

Bicycle

E-bike

Speed pedelec

Scooter

Car (owner)
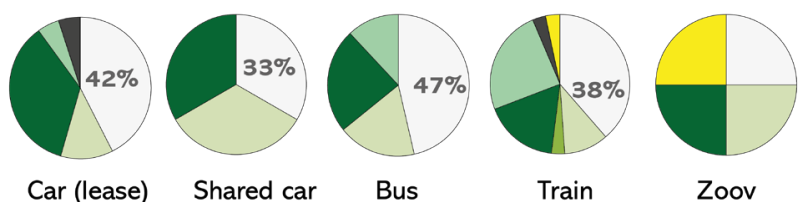

Zoov

Distances $>20$ kilometres
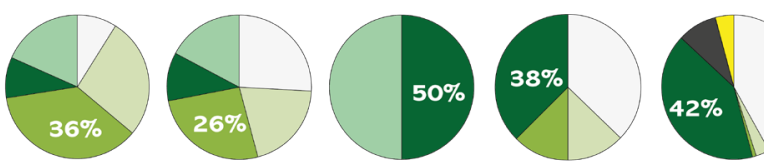

Bicycle

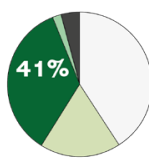

Car (lease)
E-bike

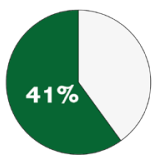

Shared car
Speed pedelec

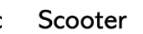

Car (owner)
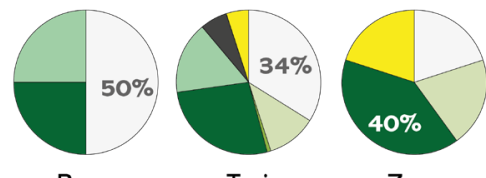

\subsubsection{Least used travel modes}

Besides the most used transport modes, the survey also presents information about the least used transport modes. For travels up to 5 kilometres, $37 \%$ answered that they use their car the least for travels for this distance (see Figure 12). The explanation for using the car the least $(\mathrm{N}=145)$ is because it is unhealthy (29\%), expensive (28\%), and bad for the environment (27\%) (see Figure 14).

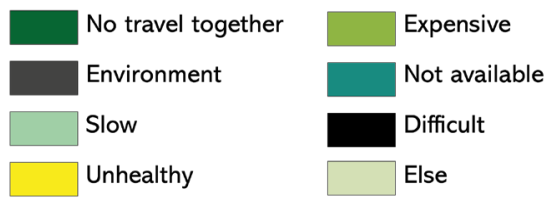

Dstances $<5$ kilometres
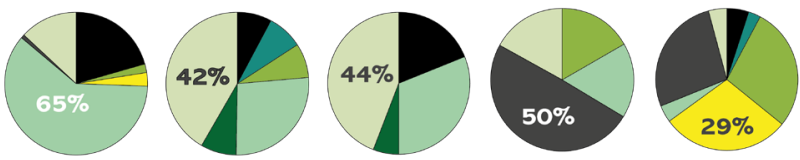

Walking

Bicycle

E-bike

Scooter Car (owner)
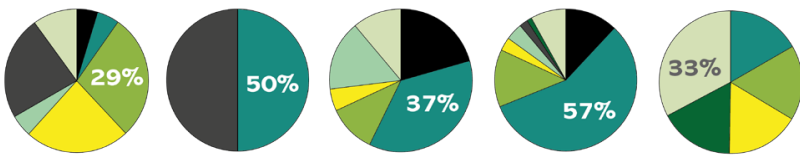

Car (lease)

Shared car

Bus

Train

Zoov

Distances between 5 - 15 kilometres
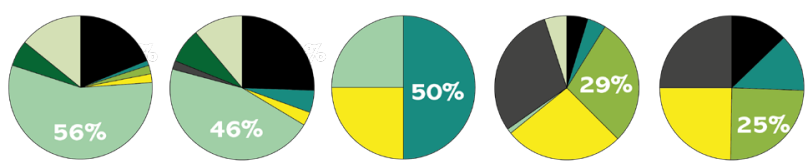

Bicycle

E-bike

Scooter

Car (owner)

Car (lease)
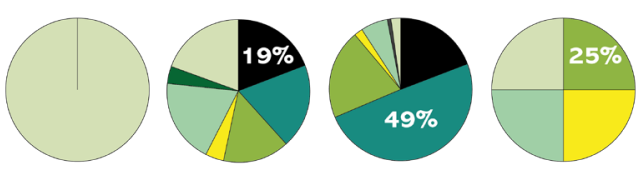

Shared car

Bus

Train

Zoov

Distances $>20$ kilometres
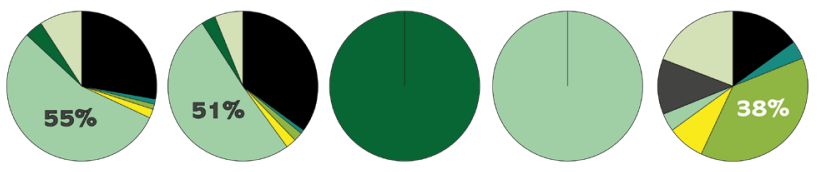

Bicycle

E-bike Speed pedelec Scooter

Car (owner)
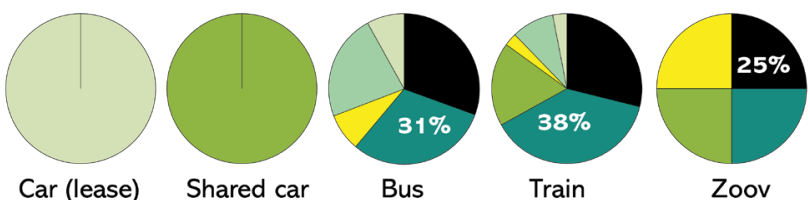

Car (lease)

Shared car

Another contrast is the number of respondents (24\%) who answered that walking is the least used transport mode for travels up to 5 kilometres. They $(\mathrm{N}=96)$ do not walk because it is slow $(61 \%)$ or difficult $(21 \%)$ (e.g., they have to carry groceries or cannot walk well).

The least used transport modes for distances between 5 and 15 kilometres are bicycle (34\%), car (22\%) and train $(18 \%)$ (see Figure 12). The bicycle $(\mathrm{N}=130)$ is used the least because it is slow (56\%) and difficult 
(19\%) (e.g. people travel with luggage or with children) (see Figure 14). The respondents use the car $(\mathrm{N}=85)$ the least because it is not well for the environment $(30 \%)$, expensive $(29 \%)$ and not healthy $(27 \%)$. For respondents choosing the train $(\mathrm{N}=70)$ for the least used mode, they explain that it is not available (49\%), expensive $(20 \%)$ or difficult (19\%). It could mean that respondents do not live close to a train station or that they do not travel much by train for distances between 5 and 15 kilometres.

The least transport modes for travels longer than 20 kilometres are bicycle (53\%), e-bike (22\%) and car (13\%) (see Figure 12). The respondent choosing the bicycle $(\mathrm{N}=198)$ as the least used transport mode responds that it is slow (55\%) and difficult (28\%). For respondents choosing the e-bike $(\mathrm{N}=81)$ argue that it is slow (51\%) and difficult (35\%) (see Figure 14). Respondents who use the car the least $(\mathrm{N}=47)$ think it is expensive (38\%), difficult (15\%) or bad for the environment (12\%).

\subsubsection{Use of public transportation}

As already mentioned in the results, public transport is not used often as a transport mode. When analysing public transportation use in-depth, the survey results show that $63 \%$ of all respondents argue that their daily activities are not accessible by bus. Moreover, the survey result show that $69 \%$ of the respondents argue that their daily activities are not accessible by train. Multiple reasons might cause it, e.g., public transport is not within reach of the daily activities or daily activities all take place within a small area were travelling by public transportation is not necessary or preferred. The output also shows that young people up to 25 years old and elderly older than 65 travel more by public transportation than people between 25 and 65.

Of all respondents, $53 \%$ never uses public transportation (see Figure 15). Only $12 \%$ travels each week by public transportation, and $22 \%$ of the respondents travel each month. When the respondents are asked how satisfied they are with public transportation, $38 \%$ is satisfied, and $38 \%$ is unsatisfied. In general, $19 \%$ of all respondents would like to travel more by public transportation. If public transportation has a more extensive offer (e.g. network density, more frequent), $37 \%$ argues that they are willing to travel more by public transportation. When 32 public transportation costs are lower, even $47 \%$ is willing to travel more by public transportation.

The current situation with COVID-19 results in $42 \%$ of the respondents using a car more often than public transportation.

\section{$60 \%$ says a car is indispensable}

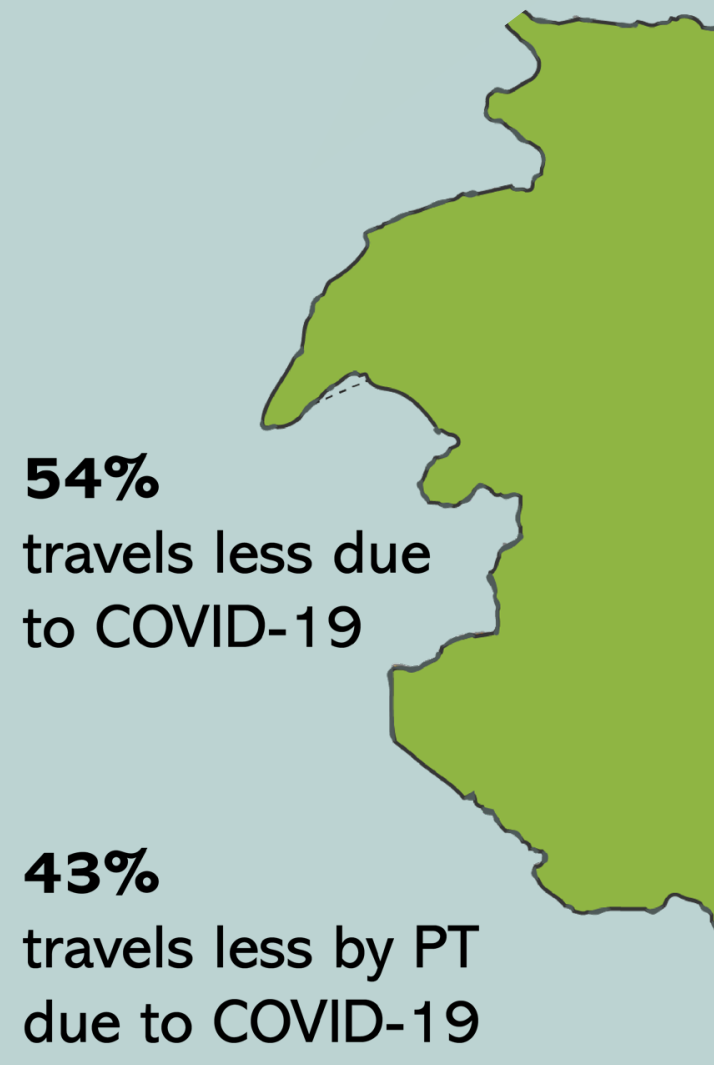




\subsection{SUSTAINABLE MOBILITY FROM A MULTI-ACTOR PERSPECTIVE}

Policies of multiple actors operating in the Achterhoek are analysed to identify the different perspectives regarding sustainable mobility and transportation in the Achterhoek. These actors (governments, transport operators and entrepreneurs) have been interviewed to get an indepth impression of how they deal with sustainable mobility development and implementation. Specifically, six in-depth interviews are done with representatives of the Province of Gelderland, a member of the Achterhoek Board, a member of the theme table Accessibility and Mobility of 8RHK, an entrepreneur active within 8RHK, ZOOV and Arriva. The policies of multiple actors regarding sustainable mobility are also discussed in the following paragraphs

\subsubsection{National government}

On a national level, the government has created aims at integrated development of the living environment. Part of this is the transportation and the way people travel from origin to destination. Multimodality will play an essential role in the future (Ministerie van Infrastructuur en Waterstaat, 2021). The future transportation system and how people will travel is predicted in multiple plans. One of these plans focusses on the future role of the car in 2040. The national government expects that the car will become as dominant in our transportation system as it is now because other modalities do not have the same comfort and travel possibilities (Ministerie van Infrastructuur en Waterstaat, 2021).

Nevertheless, cars need to be sustainable due to the necessity of sustainable and zero-emission transportation. To ensure that the mobility system fits the future demand and situation, the government aims to maintain room for cars to insure the car will remain a dominant transport mode (Ministerie van Infrastructuur en Waterstaat, 2021). Within this development, traffic safety, liveability, and efficient space use are important (Ministerie van Infrastructuur en Waterstaat, 2021). Although the prediction is that car use will become as dominant as it is right now, the government want to motivate people to reduce car use if possible, e.g. by working from home or by travelling outside peak hours. For multi-modality, the government wants to 34 connect all transport systems better (private vs public vs goods) to make a transfer between these systems more comfortable. This is also emphasized in the goals for public transportation in 2040 (Ministerie van Infrastructuur en Waterstaat, 2019):

- In urban areas, bike and public transportation are the primary transport mode;

- All public transportation is zero-emission and circular;

- Public transportation is without thresholds for all travels from door to door;

- The Netherlands needs to be the frontrunner when it comes to innovation and renewal of public transportation;

- Public transportation needs to be safer and with less hindrance for its environment;

\subsubsection{Province of Gelderland}

The province of Gelderland has developed an environmental plan (omgevingsvisie) for the whole province. This environmental plan integrates all environmental topics: housing, living environment, energy transition, circular economy, climate adaptation, biodiversity, and mobility. The core of this environmental plan is to connect, change, and green the living environment (verbinden, veranderen, vergroenen). One part of this is a mobility plan (Visie Voor een bereikbaar Gelderland) with goals for 2030. This plan's general goal is to give each inhabitant access to mobility for commuting or recreational purposes (Provincie Gelderland, 2020).

The province's strategy focuses on the most critical challenges regarding mobility and accessibility, i.e., the province main focus point is that of urban networks. They want to combine improvements into infrastructure (e.g., charging locations for electric vehicles) and efficient and smart transportation use. Stimulating smart and sustainable travel behaviour is an essential strategy to keep the province accessible with sustainable transportation.

The province uses multiple stepping stones to stimulate sustainable travel behaviour (Provincie Gelderland, 2020). First of all, they want to develop hubs (mobiliteitshubs) at the edges of urban areas so that both goods and people can change quickly on 
these transfer locations. These hubs are also used to secure the area's fine-meshed accessibility (fijnmazige bereikbaarheid) (Provincie Gelderland, 2020). Second, these transfers need to be as smooth as possible, so transfer times are short, and hinterland and centres connect well when multiple transfer modes are used (personal communication, see Interview Transcript E). Third, for short distances, the provinces aim at bike use, and for longer distances, the use of high-quality public transportation ( $\mathrm{HOV}$ ).

As mentioned above, the mobility plan is part of an integrated environmental plan for the whole region. Therefore, collaboration with other actors is essential in realizing their future goals (Provincie Gelderland, 2020). In the following paragraphs, more will be explained about how actors are working together and how they will do this in the future.

\subsubsection{RHK}

This organisation is a partnership between governments, societal organisations, and entrepreneurs. Since 2018, they are united in 8RHK [acht-er-hoek] and focus on multiple relevant themes for the Achterhoek. Within $8 \mathrm{RHK}$, there are 250 ambassadors from the region. These ambassadors are divided amongst six "theme tables", the Achterhoek board, Achterhoek regional daily board, the Achterhoek council (Achterhoek Raad), entrepreneurs, organisations in healthcare, real estate and education (see Figure 15) (8RHK, 2019). As mentioned in the $8 \mathrm{RHK}$, perspectives are represented from entrepreneurs, societal organisations and governments (Ondernemers, Maatschappelijke Organisaties, Overheid $=30$ ) (personal communication, see Interview Transcripts A).

The general vision for the region is (8RHK, 2019):

"The Achterhoek is a unique area with a large potential for development. Strong values are the beautiful living and working environment, the thriving and innovative economy and a culture of cooperation and trust. The potential we see in the strengthening and broadening of the Achterhoek as an open innovation system, space for experimentation, and increasing the living environment's quality such as the houses, the countryside, and accessibility. Space for innovation, growing in quality!"
The "theme tables" unite experts from the different organisations to work on the themes: work smart \& innovation, mobility \& accessibility, living and real estate, circular economy \& energy transition, education $\&$ job market, the healthiest region. Together they strive for a more vital region and innovative development (8RHK Ambassadeurs, n.d.). In the plans for 2030, 8RHK wants to be accessible so economic growth, liveability and tourism can increase.

Within the "theme table" of Mobility \& Accessibility, the main goal is to achieve:

- Energy from sustainable and renewable sources;

- Affordable and trustworthy transportation for all who would like to move in and around the Achterhoek;

- Travellers can easily plan their travels with their phone and internet;

- There are no obstructions to travels between the Netherlands and Germany for both travellers and operators.

Sustainable transportation goals show a focus on investment in carbon-neutral travelling. The development of a safe and dense cycling network is critical to reaching carbon neutral travels. The rise of e-bikes is critical for the stimulation and facilitation of alternative clean transport modes.

$8 \mathrm{RHK}$ aims to update the current regional and local infrastructure (personal communication, see Interview Transcripts A) and other actors. They will do this by improving the road network, so it manages the travel flow perfectly. For example, faster connections from regional roads (N18) to highways (A12/A18) should be made. Also, improved connections between public transportation and the bicycle network are made. So-called mobility hubs (mobiliteitshubs) will play a role in connecting these two networks (personal communication, see Interview Transcripts E). With investments into public transportation, faster connections and improved transfer possibilities are developed.

Besides this sustainable focused strategy, 8RHK wants to create smart and affordable transportation. One means, is that of participation in the first MaaS-pilot (Netmobiel) in a rural area. Another important goal is to innovate solutions to make the transport of goods more efficient and sustainable. 


\section{Samenwerken in de Achterhoek}

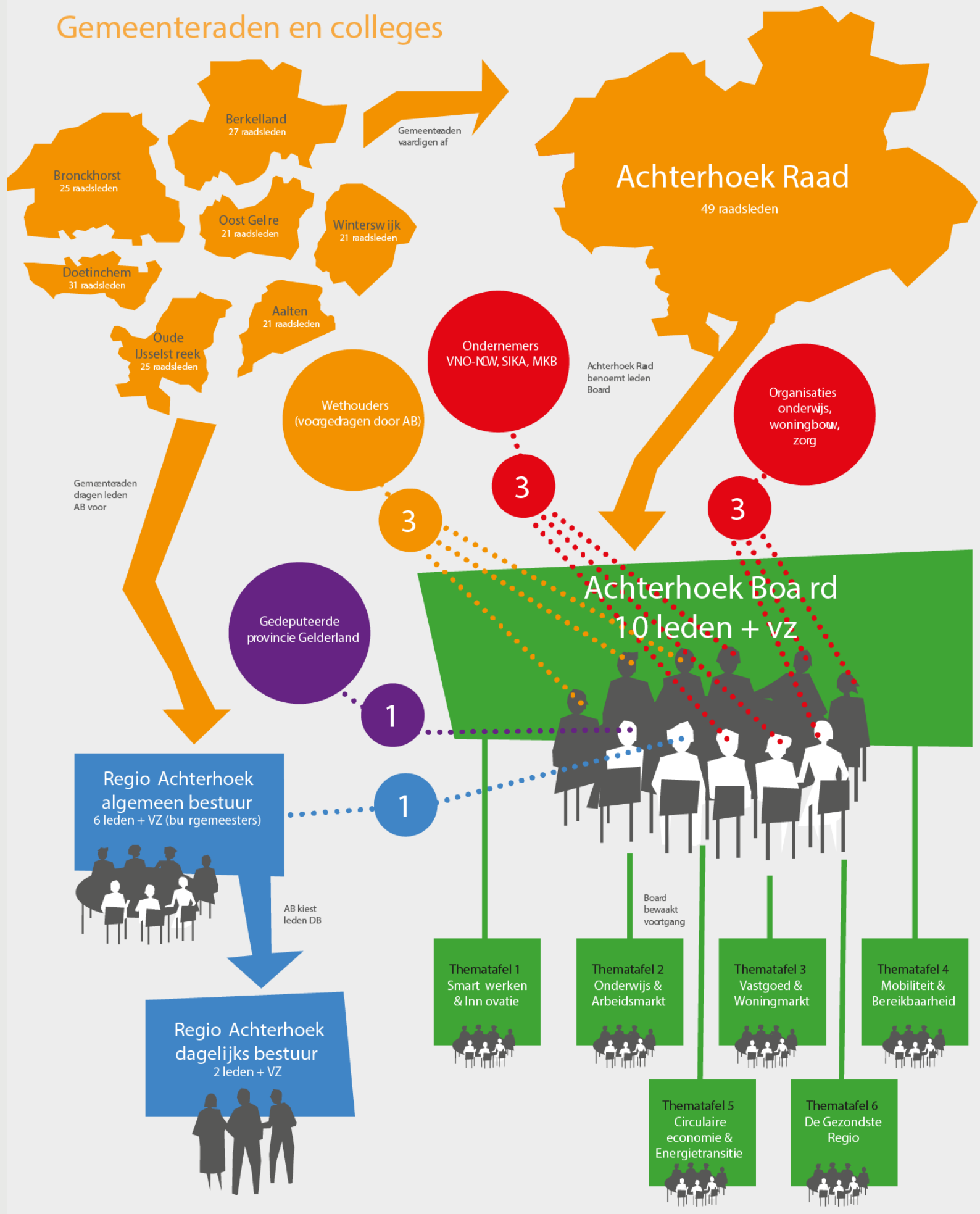

Figure 15. Collaborations within the 8RHK (8RHK, 2019) 


\subsubsection{Arriva}

Arriva is the major public transport operator for trains and busses in the Achterhoek. For 2021, Arriva aims at faster connections from the region to Randstad, Arnhem, Nijmegen, Brabant and Enschede by investing in high-quality public transportation (HOV) (Arriva, 2021). The train lines in the Achterhoek are the basis for all public transportation; all busses driving in this region are connected to the train stations (this is the so-called feeder model or visgraatmode). With improvement (e.g. higher frequency, improved connections), they hope to create a more attractive network (Arriva, 2021) (personal communication, see Interview Transcripts B). Second, the connection between small and extensive bus services will be improved so that the overall network will ameliorate for the traveller. For example, they want to connect local bus lines (streeklijn) to schools' timetables in the region, so that travellers do not need to wait long. It is also addressed in the third goal for 2021: they want to improve transfers' quality and reliability. Fourth, Arriva aims at preserving the current accessibility of small villages and the back of beyond. They do this by actively collaborating with ZOOV, another transport operator in the Achterhoek, focusing on target group transportation (doelgroepenvervoer).

Besides these short-term goals for mobility in the Achterhoek, they also aim to make transportation sustainable since they also have to stick to the governments' zero-emission demands. From 2025 onwards, they want to operate zero-emission. Therefore, they invest in electrical and hydrogen busses (Arriva, 2020) (personal communication, see Interview Transcripts B). Moreover, they use alternative fuels, which reduce carbon emission compared to standard fuels. For charging of the electrical busses, they will use only green electricity (Arriva, 2020).

\subsubsection{ZOOV}

ZOOV (also known as regio taxi) is the transport operator which facilitates transport for target groups such as the elderly, disabled people or students going to special needs education. People who have an "indication" can travel for low fares with ZOOV (Wmo-vervoer) because they have particular transport demands. This indication is awarded by the municipality and is dependent on the health and state of someone. 37
When someone does not indicate they can still travel with ZOOV, they pay the regular fares for public transportation in the Achterhoek. ZOOV does not drive according to a timetable but offers demand-responsive transportation: the traveller books a trip with them, and ZOOV picks them up around a specific time.

ZOOV transports travellers in small busses in the region. For these types of busses, there are not yet suitable electrical alternatives. Therefore, ZOOV will not directly invest in new busses because they want to wait for the market to develop an electrical bus for this transport use.

At the moment, ZOOV is also part of the MaaS-pilot of the Achterhoek. This pilot, called Netmobiel, aims to organise all transportation within one platform so that a traveller can book and plan each part of their trip in one system. For example, when travelling by train, they can pay for this trip via this platform and reserve and pay for a bike to travel the last mile of their trip.

\subsubsection{Triple O-structure}

In the Achterhoek region, representatives of entrepreneurs, societal organisations, municipalities and province are actively working together (see also chapter 8RHK). This triple O-structure is meant as a bottom-up working practice to ensure that initiatives from each actor and all their perspectives are taken into account (personal communication, see Interview Transcripts A). In the interviews, all representatives spoke that they do not believe in a top-down approach for rural areas when implementing sustainable mobility. To realise sustainable mobility, they have multiple approaches.

First of all, mobility brokers (mobiliteitsmakelaars) are working in the Achterhoek. These mobility brokers visit companies to discuss their mobility plan (e.g. how are employees travelling to work or business appointments?). They play an essential role in promoting sustainable mobility. For example, they suggest that companies invest in shared electrical cars instead of lease cars for each employee. These shared cars can be used during the week for trips from and to work or business appointments. During the evenings or weekends, these cars are available as a shared car. With this solution, the employer saves money because the cars are only used during a week. 
Governments such as municipalities are also interested in these developments of shared mobility because they do not need to invest large amounts of subsidy in mobility services that might not be used. The cooperated implementation of shared cars (or bikes/ scooters) guarantees that the services are used. The transport operator also benefits from this cooperative approach because they arrange the shared cars and guarantee the involved employer that the car will be used a large part of the week. Together, i.e., the employer, municipality, and transport operator, they organise a bottom-up mobility service where they all invest or subsidise a part of the investment needed to implement the facility. With this bottom-up approach, the availability and use of the shared car by employees, all actors expect local inhabitants to start using the shared cars. Before the use of a bottom-up approach, governments invested in mobility from a top-down approach. In the beginning, this worked out well, but after the subsidy stopped, the situations returned to the original state (personal communication, see Interview Transcript A). Another example is that of shared cars in local communities. A local energy cooperation partly run by inhabitants asked for shared cars in their municipality. This cooperation invested, together with the car dealer and the municipality. As part of the energy cooperation, the launching customers will start using shared cars, and hopefully, this will be further explored by other inhabitants.

Second, with the triple O-structure, change in the current transport network might be easier realised (personal communication, see Interview Transcript E). For example, when a company wants to be accessible by bus, a cooperative, bottom-up working way is possible. All actors involved are already working together on several topics with the triple O-structure. It also corresponds with the present (semi-) governments' aim: determine the community's transportation demands.

So, the triple O-structure is all about sharing facilities, sharing costs and risks to enable bottomup facilities for inhabitants, societal organisations, entrepreneurs, and the governments, i.e., everyone being in the Achterhoek. This working practice enables customization for the development and implementation of sustainable mobility in this region. Although the triple O-structure aims to work bottomup, this is not always experienced by all actors in practice. The working practice is still policy-oriented, and governments still influence the whole process (personal communication, see Interview Transcript B, F). Moreover, with all actors having different individual aims, it is still hard to unite these aims in practice. For example, leisure entrepreneurs want to rent out bikes for people in the region; a transport operator wants to travel with full busses. The company facilitating the bikes wants to have the bikes used as much as possible. Together, they can achieve this by locating the bikes at a bus stop or carpool. Tourists will enter the region and enjoy the region by bike (personal communication, see Interview Transcripts D).

\subsubsection{Sustainable travel behaviour}

With triple $\mathrm{O}$, as a bottom-up structure, they strive for determining the mobility demands of everyone. Thoughts and opinions of inhabitants of the Achterhoek are determined in a panel (Achterhoek Panel) and measured regularly. In practice, when interviewees are asked how to include the local inhabitant and their travel behaviour in the transition towards sustainable mobility, none of the interviewees directly has a solution. Each interviewee says that it is hard to get all travellers out of their car because everyone in Achterhoek depends on their car. Moreover, some interviewees doubt the effects of current policies aiming for sustainable travel behaviour. With many busses, shared vehicles, and advertisement for sustainable mobility, use of those sustainable services is not yet guaranteed. Travellers want to go fast, easy, and comfortably to their destinations. When a car is available in front of their house, they will probably take the car (personal communication, see Interview Transcripts B). For travellers, the use and availability of extra transport modes (e.g. shared vehicles) only mean that there is one more change between transport modes. So, travelling becomes more complex than travelling by an owner car (personal communication, see Interview Transcripts B, C, F).

All in all, most of the interviewees say that it is hard to determine what travellers want. Some interviewees even say that the traveller does not exist (personal communication, see Interview Transcripts A, B). Each traveller has individual needs and demands, which differ per person. Probably travellers want to have the opportunity to travel wherever they want to travel 
(personal communication, see Interview Transcripts A, B). Some interviewees argue that you should not ask what the traveller wants but should focus on what might fit the traveller's requirements.

Therefore, most of the interviewees are happy with the development of Netmobiel, a MaaS-application that is currently launched in Achterhoek. Travellers can book and plan their trips easily from door-to-door. Some interviewees doubt the direct effect of MaaS on travel behaviour. However, in 10 to 15 years, they assume that the "new traveller" is created and might see the benefits of (shared) public transportation over individual car use. For successful implementation of this part of mobility, the actors should also take the lead themselves: travel by (shared) public transportation, bicycle or e-scooter and leave the unsustainable car (personal communication, see Interview Transcripts C, D).

As mentioned in the province of Gelderland, the province aims to develop mobility hubs (mobiliteitshubs). These hubs are meant as transfer location between urban and rural locations. Multiple transport modes need to be available at these hubs, such as bus, shared car, shared bikes, or scooters. Also, there should be room for taxi services like ZOOV. Although these mobility hubs will serve public transportation travellers, some interviewees are sceptical how much it affects people's will to change their mobility patterns (personal communication, see Interview Transcripts B, C, F). The public transport travellers will benefit from better services on these locations and improved transfers, but it will not directly lead to more sustainable mobility for every traveller. So, the locations of these mobility hubs should be chosen very carefully. Data-driven practices can do this: analysis of travel data, and based on that, data locations can be chosen (personal communication, see Interview Transcripts E).

Besides focussing transportation, another focus point should be transportation efficiency, according to an interviewee (personal communication, see Interview Transcripts C). When people are travelling by themselves in a diesel-fuelled car, it will not be sustainable. If they travel with more people together in the same diesel car, they still emit, but only one car. These shared rides should also be part of the transition towards sustainable mobility (personal communication, see Interview Transcripts C).

\subsection{DEMANDS AND WILLINGNESS}

\subsubsection{Bureaucratic system}

The analysed policies and interviews aim for a particular demand for customization of the transition towards sustainable mobility. In urban areas, where many people travel by public transportation in a dense transportation network, it is easier to implement sustainable transportation and demand sustainable travel behaviour from inhabitants compared to rural areas (personal communication, see Interview Transcripts B. E). According to some interviewees, a systemic approach in organizing sustainable transportation is used in urban areas (e.g. city of Arnhem) (personal communication, see Interview Transcripts C, F). In rural areas, as the Achterhoek, travel demands are less generic and differ more. Moreover, fewer people are travelling in a sparse transportation network compared to urban areas. Therefore, multiple actors aim for a customized approach in the transition towards sustainable mobility.

However, some interviewees address that there is no room for customized sustainable mobility implementation because higher governments (province, national government) aim for the same transport opportunities and systems everywhere in the Netherlands. It can result in friction between local governments and regional or national governments (personal communication, see Interview Transcripts B, D, F).

Some interviewees address the bureaucracy of the system. They claim that the development of local and regional policies remains in discussing and talking about the future, discussing policy measures. Therefore, everything remains very abstract. In practice, initiatives do not always become as planned for in the policy or mobility plan. The interviewees say that this could be overcome when each actor shows firmness and audacity to change the system and transition towards sustainability. Moreover, some interviewees claim that there is only a focus on new technological solutions and innovations. Current solutions, which still have a preferred performance, are moved off the table because some policymakers are only open to new technologies (personal communication, see Interview Transcripts B, C, F). 


\subsubsection{Infrastructure}

As mentioned by the interviewees, the current bus network is very scarce. It will not change in the future, because it is more important to have a scarce network of high quality and many busses than driving through the whole region with only air [no passengers] in the bus (personal communication, see Interview Transcripts F). What will change in the future is the type of busses driving in the region and the rest of the Netherlands. Instead of current gas or diesel-fuelled busses, electric and hydrogen busses will transport passenger in the future (personal communication, see Interview Transcripts B-F). It is according to the current transport operator's policy in the Achterhoek (Arriva, 2020). In 2025 they want to be carbon neutral as an organisation and transport operator. It means that all their busses and trains will be zeroemission. Changing to zero-emission vehicles is not without challenges.

Currently, there are no zero-emission busses equipped for long distances. For short distances, where small busses ( $<9$ persons) are used, there is also no zeroemission bus available yet. These are challenges that also count for target group transportation, like ZOOV (Arriva, 2020) (personal communication, see Interview Transcripts F).

The transition to zero-emission vehicles also means that the infrastructure needs to be updated. Charging infrastructure needs to be placed on bus stations in the operating area. Moreover, charging takes more time than fuelling fuelled busses. Therefore, more busses are needed to operate, because the busses cannot be used as time efficient as the old-fashioned busses. All in all, the transition towards sustainable transportation will result in higher costs for both operators and governments on short term. On a longer term, the costs will be lower, because there are lower costs for fuel and maintenance (personal communication, see Interview Transcripts B, E).

\subsubsection{Willingness to use sustainable mobiltiy}

All interviewees are asked about personal travel behaviour and how this might be changing in the coming ten years. Some respondents admitted that they are fond of car use over public transportation services. They want to drive electric, but shared 40 public transportation is not something they currently favour themselves. An interviewee also supported that the transport operator employees can travel for free by public transportation in the operating area. Although these employees know the timetable of all busses and trains in the region by heart, something holds them back from travelling by (sustainable) public transportation (personal communication, see Interview Transcripts B). To know when a traveller is willing to use sustainable public transportation or sustainable private transportation (e.g. electric car), the different travel groups and their demands need to be determined (personal communication, see Interview Transcripts C, F). It will also improve MaaS because this demand responsive transport initiative can better fit the travel groups' demands when these demands are precise. However, this is challenging because travel behaviour differs (personal communication, see Interview Transcripts C, E, F).

Another remark given by one of the interviewees addressed the need for accessibility of sustainable transportation opportunities close to job locations. Employers should emphasize using sustainable public transportation over unsustainable private transportation. The employer could discuss the possibility of revising the bus network to stop close by the job location (personal communication, see Interview Transcripts C, D). Vice versa, spatial development around train stations and the placement of houses and job locations close to public transport hubs (e.g. train stations, bus station) could affect the willingness of using sustainable transport modes because travellers might not feel a distance-threshold to use public transportation (personal communication, see Interview Transcripts C, D). However, other interviewees are not keen on these solutions to move people towards sustainable transportation. Spatial development, including building houses and facilitating job locations, need to be everywhere. The interviewees assume that the people living close by public transportation, who possibly use these services more often, will not be the tipping point in this whole transition (personal communication, see Interview Transcripts B,C, F).

The interviewees argue that private transportation should be of equal value as public transportation; it should be as comfortable, flexible, and affordable as private transportation. As this is not often the case, 
travellers' incentives, or motives for using public transportation are not easily changed (personal communication, see Interview Transcripts A-F).

Another significant influence of using sustainable transport modes is that of the availability of charging infrastructure. As mentioned in the previous paragraphs, it is challenging for public transportation to organise this, because it involves a lot of other actors such as energy societies and governments. For private transportation, however, are these facilities yet well-equipped and available in the study area. Nevertheless, interviewees argue that people living in the Achterhoek assume that there are not many charging locations and that travelling by electric cars is not attractive (personal communication, see Interview Transcript $E$. This is also confirmed in the survey results as mentioned in the previous paragraphs.

\subsection{CHAPTER SUMMARY}

The Randstad and Achterhoek have many differences in terms of travel behaviour of its population. In general use of public transportation is higher in the Randstad, and car use is higher in the Achterhoek. The OViN data between 2010 and 2017 showed that there is a an increasing amount of cars per households, that travelling by car slightly increased, and travelling by public transportation slightly decreased. Car use is dominant for all travel motives, except for education and recreation. The most used transport modes is the bike for travels $<5 \mathrm{~km}$. For longer distances, the car is the most used mode. The least used transport mode for travels up to $5 \mathrm{~km}$ is the car. The bicycle is the least used mode for longer distances.

Policies of governments and transport operators show a focus on sustainable transportation. All actors aim at working together via a bottom-up triple o-structure. With this strategy they aim at including all actors in the implementation of (sustainable) mobility. Nevertheless, the actors find it challenging to include the demands of travellers and include them in the process. 


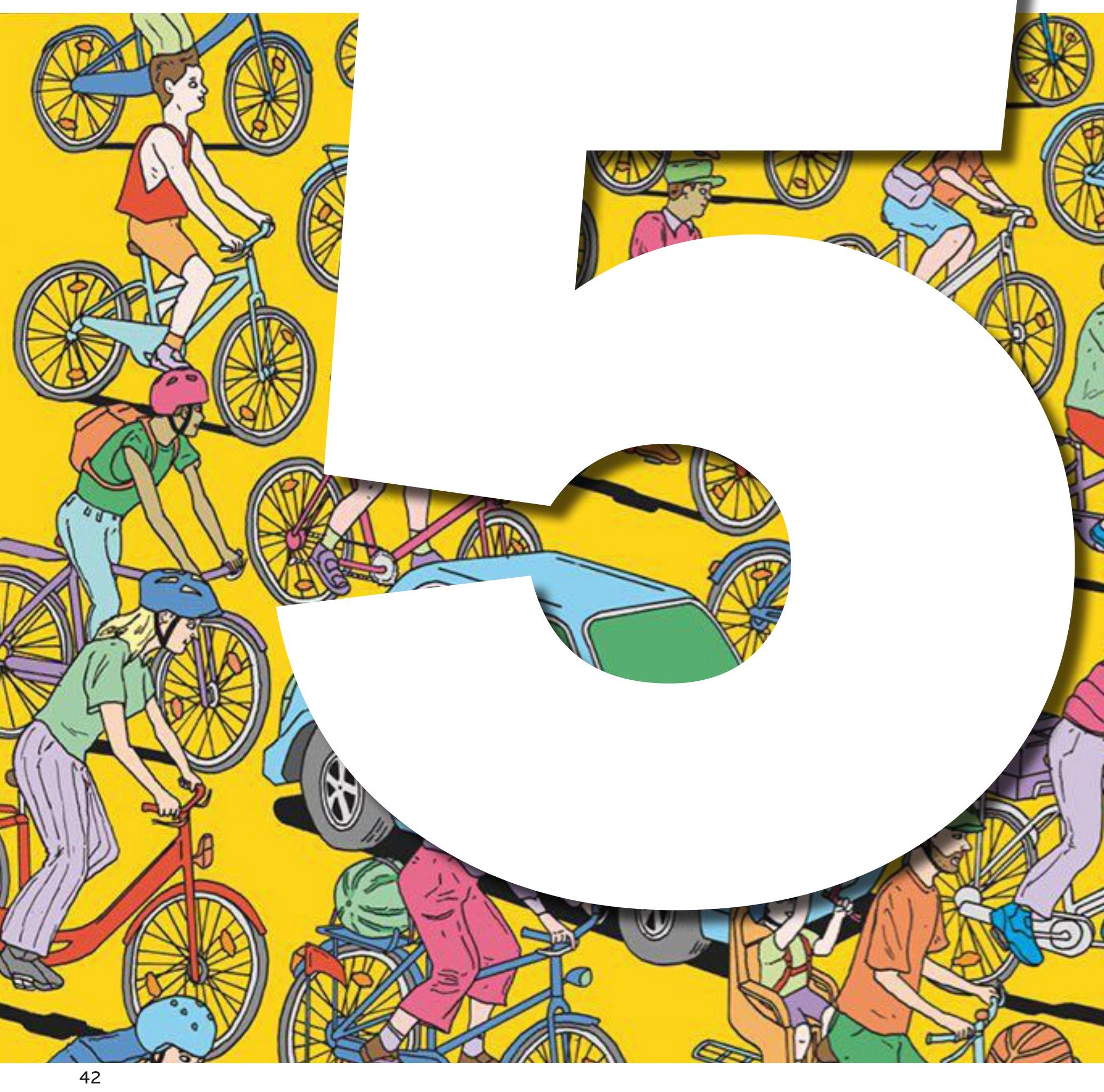




\section{DISCUSSION}

In this chapter, the research results are evaluated in relation to the research objectives. First of all, the corresponding questions per research objective are answered. Second, the methodology and results of the study, including its validity and reliability, are discussed. Third, the limitations of this research are addressed. Fourth, there is a discussion of the practical considerations of the research. After that, the ethical implications are dealt with.

\subsection{DISCUSSION OF RESULTS}

\subsubsection{Concepts of Sustainable Mobility}

In this research, sustainable mobility has been researched from the perspective of multiple actors. Since the actors have different roles and responsibilities, the definition and methods to achieve sustainable mobility differ. Compared to previous research, the results are pretty similar: all actors are aware of the current, most of the times unsustainable mobility system represented by high private car usage, and all aim for boosting the use of more sustainable transport modes, such as public transport, walking and cycling (Banister, 2005; Berger, Feindt, Holden, \& Rubik, 2014; Black, 2010; Castillo \& Pitfield, 2010). Moreover, not all actors directly aim for sustainable mobility (Berger et al., 2014). For example, transport operators only need to facilitate travellers' transportation, but the operator does not aim for sustainable mobility. They only need to deliver sustainable, zero-emission public transportation as government policy requires. So, transport operators only focus on the sustainable transportation of the traveller, meaning that the sustainable travel behaviour of the traveller is not directly important for operators. On the other hand, governments, do aim for sustainable mobility, but do not exactly know how they can realise this besides implementing sustainable transportation. They define sustainable mobility as travelling without emitting, so in practice people need to travel by "close to" zeroemission modes such as bicycle, electric car, or public transportation.

\subsubsection{Concepts of Modal Choice}

As mentioned in section 2.3, the modal choice is determined by the location of activities (e.g. working, shopping), individual factors like income, education level, and access to activities using an existing transport infrastructure (Geurs \& Wee, 2004). As shown in the Land Use Feedback Cycle by Wegener \& Fürst, (1999), travel behaviour is also affected by a combination of land use and transport factors (see Figure 2.1). These factors serve as implicit and explicit forces influencing travel behaviour. Together they define the needs, opportunities, and abilities for travelling. The combination of these result in motivation to travel to a particular location and feasibility of these actions. Altogether, this results in behavioural choices (see Figure 2.2).

When comparing urban and rural areas, the needs, opportunities, and abilities defining travel behaviour differ. It is hard for rural areas like the Achterhoek to get travellers out of their private cars. This is also demonstrated in the survey where a majority said that their day-to-day activities (i.e. work/school, shopping) are not accessible by public transportation. Moreover, most travellers do not like to travel by public transportation because it is slow, difficult, expensive, and not always reachable within preferred walking or cycling distance. When public transportation would be cheaper and has a denser network, including higher frequency, it was found that respectively $47 \%$ and $37 \%$ of the respondents would be willing to travel more with these transport services. Therefore, if governments and public transport operators grant 
these travellers' requirements, the number of people travelling by public transportation might increase.

On the other hand, travelling by car is experienced as easy, cheap, and fast for most of the respondents in Achterhoek. For trips with multiple travel purposes, there is also a preference for travelling by car and not by public transportation. Concerning sustainability, most of the respondents do not want to change to an electric car, even if electric cars have a good action radius and sufficient charging locations. Also, when it comes to shared cars, it was found that a majority of the people (47\%) in the Achterhoek are not yet willing to use them. This might change when the government starts policies that focus on (higher) subsidies for driving electric vehicles. Since the regional and provincial government are improving the cycling network, an increase in the use of e-bikes is likely, especially since people in the Achterhoek are willing to travel more by bike instead of travelling by car. The need for these approaches for stimulating sustainable travel behaviour is emphasized by Hamidi \& Zhao (2020). Specifically, they conclude that policymakers and spatial planners should follow a holistic approach for designing policies to stimulate travellers to change towards sustainable travel behaviour. Moreover, Ahmed, Adnan, Janssens, \& Wets (2020) address that a more personalized travel planning approach for policies can effectively promote sustainable travel behaviour.

\subsubsection{Differences in Travel Behaviour of}

\section{different travellers}

As found in the data analysis of OViN/ODiN, the survey and the conducted interviews, there are differences in travel behaviour. In general, car use is the dominant travel mode used by most travellers. For public transportation, three groups of travellers can be identified. Travellers between 25 and 65 who do not use public transportation often and those who use public transportation regularly pertain to the young age group $(<25)$ and elderly $(65+)$.

According to the survey results, travellers between 25 and 65 do not use public transportation often. Car use

${ }^{4} 25 \%$ would be willing to use an electric car and $27 \%$ of the respondents voted in this age group is high, and most of the respondents argue that a car is indispensable in the Achterhoek. This is confirmed by the findings in OViN/ODiN and the interviews. People want to change their transport modes to sustainable modes such as cycling, walking, or travelling by bus, but only for short distances. However, only travelling by public transportation instead of travelling by car is not a remedy. Shared cars as transport mode are also not a travel mode favoured by many. As mentioned in the previous section, some respondents said that they would be willing to travel more by PT under different circumstances (costs, network frequency). Nevertheless, inhabitants of the Achterhoek do not all have this attitude towards travelling by public transportation, since $53 \%$ does not travel by public transportation at all, and $69 \%$ will not be travelling more by public transportation in the future.

With this research, the area's spatial structure in relation to travel behaviour has not been researched. By comparing the postal codes with travel behaviour, patterns could have been identified, as done by Bleijenberg (2012). In that research, it was found that people living close to public transportation stations (bus or train) have other travel behaviour than people living in the area's outskirts. This is also emphasized by Christiansen, Engebretsen, Fearnley, \& Usterud Hanssen (2017), who say that travel mode choice and the spatial organisation of an area affect each other. For example, limited parking spaces at home and at destinations could result in travellers using a car less (Christiansen et al., 2017). Moreover, the composition of households and lifecycle stages (e.g., student, young professional, parent, retired) could have been interesting to compare with the results, as emphasized by Delbosc et al. (2019) and Chatterjee \& Scheiner (2015). A focus on travel behaviour per life cycle stage will result in a better understanding of travel behaviour, and therefore policymaking can be improved with a life-cycle oriented approach (Zhang \& Van Acker, 2017).

In the survey, the respondents are asked about sustainability and the effects of their travel behaviour on the environment. A more specific result could have been achieved if a distinction had been made between non-environmentally aware travel behaviour and environmentally aware travel behaviour. The focus on these two "clusters" in travel behaviour can 
help improve understanding of travel behaviour, as emphasized in the research of Prillwitz \& Barr (2011). This has not been included in this study because too little information was retrieved in the survey about what sustainability means for each respondent.

\subsection{4 (Governmental) Policies on Transportation and Sustainability in Rural Areas}

Overall, each government (national, provincial, regional, and municipal) aims at sustainable mobility with zero-emission (public) transportation. Moreover, with the use of mobility hubs, improvements in the bicycle network, and smart mobility, they aim to develop and implement sustainable mobility. With the triple-O structured collaboration, costs and risks are shared for all participating actors such as transport operators, entrepreneurs, and governments. From the interviews and policies, it can be concluded that this structure enables bottom-up practices and results in collaborations between actors to develop and implement sustainable transportation opportunities. Research confirms that bottom-up structure and joint working contribute to sustainable mobility transition (Bartle \& Chatterjee, 2019; Berger et al., 2014).

However, there are various hindrances to the implementation of sustainable mobility. First of all, governments and transport operators do not know what should be done to motivate people to change to sustainable travel behaviour. Second, governments are currently focussing a lot on sustainable public transportation. However, from the survey output, it is found that people are not satisfied with public transportation as it is in its current state. Therefore, the attitude towards public transportation needs to be ameliorated; else it might reduce travels by public transportation in the future (McCormick et al., 2013). From a sustainable point of view, most of the people living in the Achterhoek are, in principle, not concerned about the effects of their travel behaviour on the environment, as was found in the survey. As mentioned in the interviews, travellers will possibly only use public transportation when it offers the exact characteristics of private transportation, such as travelling by car, which is also confirmed by a research of Pucher \& Renne (2005), Knutsson (2010) and Bleijenberg (2012).
Moreover, projects and policies driven by government and business, aiming for sustainable mobility, do not change much to travel culture (Berger et al., 2014) because traveller groups have different needs. Therefore a policy fitting all traveller groups will be difficult to realise (Julsrud, 2014). With the current policies focusing a lot on sustainable public transportation, only public transport travellers will be affected, instead of moving to sustainable mobility for all travellers.

\subsubsection{Multi-actor demands for using or implementing sustainable travel modes}

When it comes to implementing sustainable transportation, a clear distinction is visible between policies and practice. Currently, all governments and transport operators are working towards sustainable transportation by investments into new technologies (e.g., zero-emission, electric buses, shared vehicles, efficient use) and plans (e.g., mobility plans) theoretically result in sustainable mobility. These plans aim to achieve sustainable mobility, but there are requirements and hindrances for implementation in practice. As demonstrated by the results, customized public transportation is necessary to work towards sustainable mobility in the Achterhoek. However, with different demands of government and operators, a customized approach is not always possible. This also related to the fact that government policies remain very abstract, and it is unclear how policy goals can be achieved. To overcome this, firmness and audacity are necessary. As presented in the results, not all interviewees are willing to use the sustainable transportation opportunities they initiate themselves as governments or transport operators. As long as the initiators themselves are unwilling to use a particular transport mode, it is doubtful that the public would be willing to start using these sustainable transport modes.

Besides these considerations, transport operators demand new infrastructure for charging locations for electric busses. This infrastructure and the price of new vehicles is higher than the costs of old-fashioned transportation. So, both operators and governments' 
investments are necessary to cover the higher costs of sustainable transportation with the current bus fleet's electrification.

Regarding the cooperative triple O-structure, it was found that all interviewees demand a way of working together in a bottom-up structure to realise sustainable mobility in the future. This is also emphasized by confirming that transition management actors should consider the possibilities to work together with other actors to facilitate sustainable mobility. However, the demands of multiple traveller groups are not always considered. With a differing transport demand and mobility for each group, it will be challenging to facilitate sustainable mobility for all (Banister, 2005; Farla et al., 2010; Soder \& Peer, 2017). Therefore, actors should consider targeting individual travellers directly because other studies show that multi-actor driven mobility measures are not efficient (Soder \& Peer, 2017).

Summarizing, this research shows differences in all the involved actors' expectations and behaviour. With a cooperative structure, actors aim at realising sustainable mobility. However, current policies focus on the provision of sustainable transportation instead of focusing on sustainable mobility, without a complete understanding of the needs, opportunities, and abilities of the travellers and the actors' goals. This is an important finding in understanding the challenges regarding developing and implementing sustainable mobility in rural areas. Therefore, for establishing sustainable mobility, an approach that emphasized changing travel behaviour for specific traveller groups would be more successful (Ahmed et al., 2020; Hamidi \& Zhao, 2020; Zhang \& Van Acker, 2017).

\subsection{RESEARCH CONSIDERATIONS}

In the following section, the research considerations, methods and execution are discussed. First, issues within the survey design, sampling method and representativity of the research are addressed. Second, the use of different methods for data collection is discussed.

\subsubsection{Survey Design}

For the survey design, the OViN and ODiN surveys are used as a guideline. First of all, these surveys are of high quality and are targeted to measure travel behaviour and mobility in the Netherlands. Secondly, using the same parameters and similar questions as OViN/ODiN, the output could be compared easily with the OViN and ODiN output.

For the survey, snowball sampling was one of the sampling methods used. Snowball sampling is beneficial when little is known about the study population. However, it also has some disadvantages because respondents might belong to a particular group, and therefore the study can be biased (Kumar, 2011). To overcome this, the survey has also been distributed via other platforms (see chapter Methodology). To guarantee internal consistency, the results' output has been split into two parts before the results were analysed. By doing this, answers to questions were comparable and it is made sure that the questions are all understood the same way (Kumar, 2011).

Another issue is that of the distribution of the survey in a panel. Participants of this panel are already willing to fill in surveys, and they can earn points with filling in these surveys. Therefore, the survey answers might not always represent the true voice of all the people in the Achterhoek, since part of the respondents only wanted to earn points.

The survey output did result in a representative sample population $(\mathrm{N}=399)$ for the Achterhoek as a whole. However, for specific age groups, the results are not representative. If the results would all have been weighted, a better result could have been presented for the different age groups or other characteristics. Luckily, the OViN/ODiN outputs are representative for all characteristics of the area (e.g., age, education, occupation). 


\subsubsection{Data Collection}

This research was conducted by analysing governments and transport operators' policies, analysing OViN and ODiN datasets with travel data, conducting a survey, and conducting in-depth interviews with 1 or 2 representatives per actor. These methods have been chosen since they address the study goal's concepts from both a quantitative and qualitative approach.

The interviews were held with (semi-) governments, public transport operators, and business. The public, so the true users of mobility in the study area, are only included via the survey and other relevant data provided by ODiN/OViN. Although the survey respondents have answered a large variety of questions related to (sustainable) mobility, it would have been good also to include this group in the interviews. They have not participated in the interviews because only a small group could be interviewed. This group would not represent the sample population and therefore result in bias. Nevertheless, focus groups could have been used to overcome this issue.

Another concern related to data collection is that the theoretical part of the research (e.g., analysis of scientific papers), and the survey focussed on sustainable mobility. The interviews were intended to focus on sustainable mobility, but all interviewees did actually focus on sustainable transportation. They have been asked about sustainable mobility, but the respondents did not know how to involve change in travel behaviour in their work or not part of their jobs. This could have been overcome by selecting the interviewees better and ask them specifically if they also focus on mobility instead of only focussing on transportation. Nevertheless, it also shows an incongruence between practices and science. In science, a wide variety of research has been done into sustainable mobility, as mentioned in chapter 2. In practice, the results show that the focus is not on mobility, and the travellers, but on transportation. Therefore, the triangulation of data (scientific) literature, survey (OViN/ODiN, survey), and interviews is challenging because the interviews did not result in a complete view of mobility.

Another issue with data collection is the selection by COROP areas. The COROP region 14 , as used for the selection for the Achterhoek consists of the municipalities Lochem, Zutphen, Berkelland,
Oost Gelre, Winterswijk, Aalten, Oude IJsselstreek, Doetinchem, Bronckhorst and Brummen (see Appendix). However, in this research the municipality of Brummen is not included in the study area. Moreover, the organization 8RHK and its policies only focus on the municipalities of Bronckhorst, Berkelland, Oost Gelre, Winterswijk, Aalten, Oude IJsselstreek and Doetinchem. The municipalities of Lochem, Zutphen and Montferland are not included in their policies. These three municipalities excluded from the $8 \mathrm{RHK}$ policies were not interviewed, so development and implementation goals considering sustainable mobility might differ for these municipalities.

\subsubsection{Summary of limitations}

Overall, the used methods and results are generalisable for the study area, but this does not imply that the findings represent other rural areas. Moreover, for this study, interviewees from this study area where used. In other rural areas, working practices and policies might be different.

\subsection{ETHICAL CONSIDERATION, RISKS AND CONTINGENCIES}

In this thesis personal data of respondents (both survey and interviews) is gathered. All respondents (both survey and interview) are asked before they started their participation if they agreed with processing their answers for this research. All data is anonymised, and responses are presented in that way that it cannot lead to an individual respondent.

The data collection for the survey lasted for four weeks. When respondents filled in the survey, their data was safely stored in the survey program, and an offline backup is frequently made and stored on the researchers' laptop. After the data collection was complete, all data is deleted from the survey program.

The data collection for the interview is done by recording the interview and making notes. Before the interview, each interviewee is asked to fill in a consent form (see appendix). Moreover, the information of the consent form has been repeated before the start of the interview. After conducting the interview, the MP4 file of the interview is uploaded to Amberscript. Names of the interviewee or from other persons spoken about in the interview are anonymised. The 
rest of the interviewees' answers are also anonymised, so the things said, cannot lead to some-one specific. A potential risk is that the context needs specific details about the person (e.g. the stakeholder is a bus operator, and from that perspective, something is said). Therefore, before the analysis of the interview will be presented (e.g. to supervisors, or in the final thesis), the interviewees received the transcribed interview and the analysis. So, if they did not agree with something said, they were able to give remarks or withdraw their interview. For analysis of the interview output, Atlas.ti is used. This program fully complies with the GDPR. After the analysis, the data was deleted from Atlas.ti and stored on the researchers' laptop and drive of the University of Twente.

The participants of the survey were reached via (professional) social media (sponsored post on Instagram, social network, Linkedln), by sending the survey link to governments and request local media (e.g. websites, newspaper (de Gelderlander), radio stations) to put the link on their website. Also, a panel with participants of the Achterhoek was used. To make sure to find enough respondents, a reward was given to three respondents. The reward con-sisted of a cheque of $€ 50$ for bol.com.

All files were stored on OneDrive from the University of Twente. Besides that, all GIS data were stored on the researcher's laptop. All data ranging from policies, papers, survey- and interview data are also stored on this OneDrive. Each week, a backup was made of this data and sent from and to my university email address. Moreover, the same data is backed up on an external drive each week.

After the research is conducted, the data will not be made publicly. If necessary, the anonymised data could be shared, but only on request and with the permission of the respondents. This is also stated on the consent form (see attachment) which respondents filled in before participating in this research. Interview data (transcribed files) could also be shared in the future, but only on request and after permission of the interviewee. 



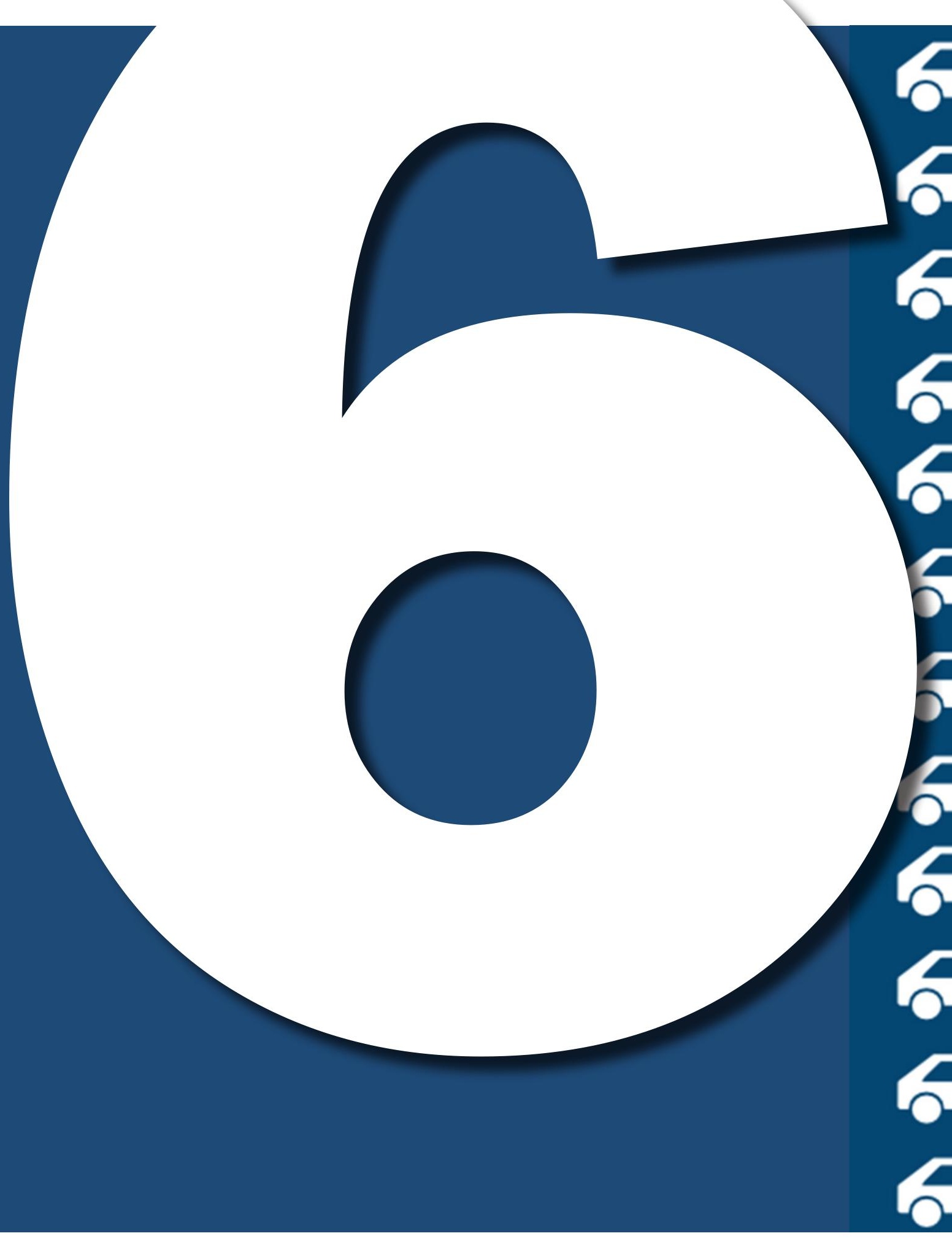




\section{CONCLUSION}

\subsection{CONCLUSIONS}

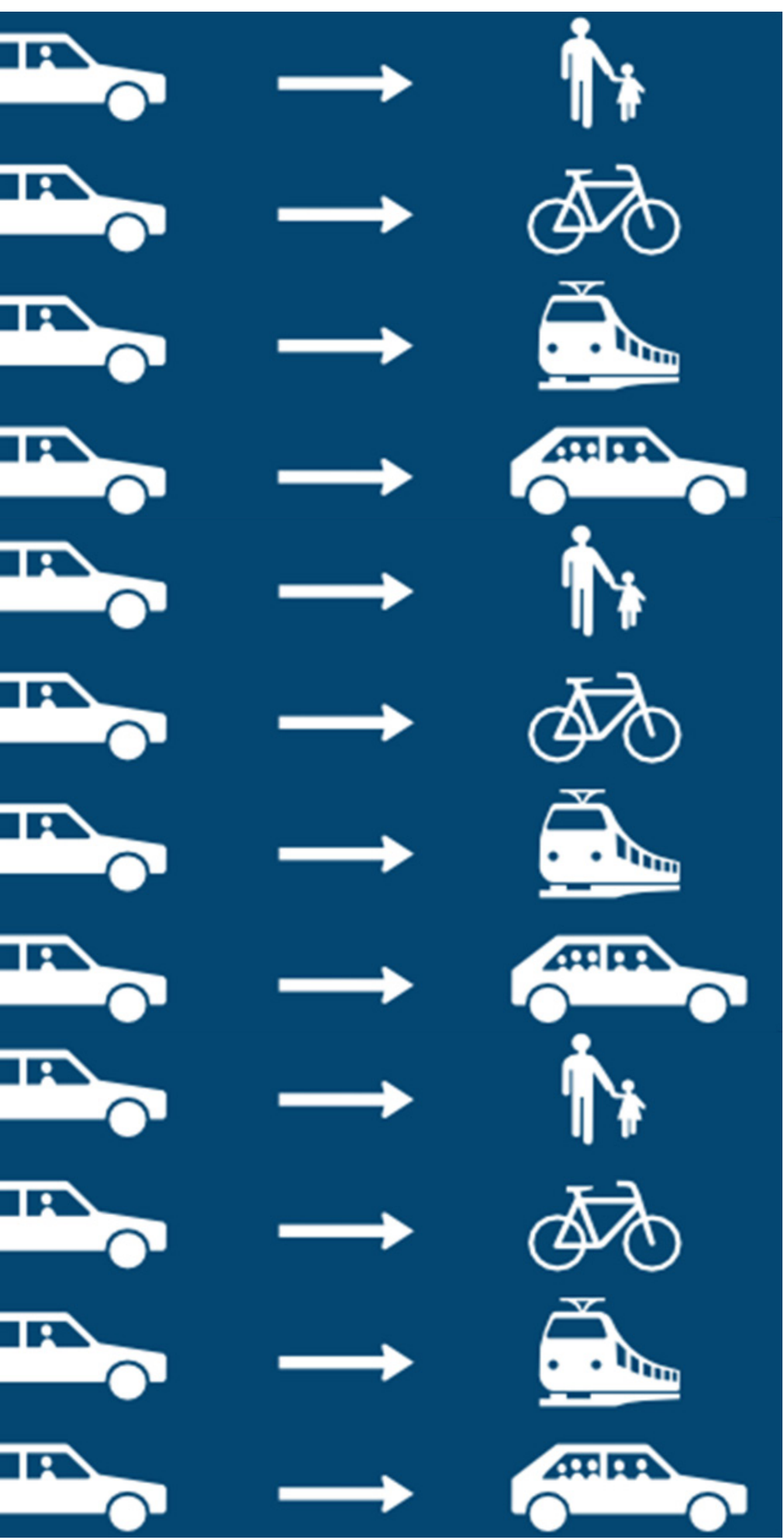

This research aimed at identifying challenges and opportunities of the transition towards sustainable mobility in Dutch rural areas from a multi-actor perspective. As showed in the conceptual framework in chapter two, the perspectives of (semi-) governments, transport operators, and travellers have been included in the research. Per actor, there are multiple challenges and opportunities determined.

For governments, the challenges for implementation and development of sustainable mobility are most within the change of travel behaviour of the travellers. Current policies focus on cycling, public transportation and shared EVs, but policies do not really focus on changing dominant car use and how travellers can be motivated to use (other) sustainable transport modes. Moreover, the current bottom-up working practices with other actors (entrepreneurs, societal organisations, and business) should also consider the inhabitants themselves, so an even more bottom-up structure can be realised, and policies and practices will fit the demand all actors better. So, the opportunities for governments in rural areas are to include the needs, opportunities, and abilities (NOA) of travellers in their region in future policies.

For transport operators, the current road towards sustainable mobility mainly focusses on development and implementation of sustainable transport. For them, the challenges are in realising a sustainable public transportation network (including infrastructure), together with governments, which facilitates all potential travellers and travel demands when travelling from and to rural areas. For the Achterhoek a specific challenge is to collaborate with other actors for bottom-up transport facilities such as shared vehicles and creating other routes to facilitate 
employers. The opportunities are in a collaborative development of sustainable public transportation which implies in higher benefits for the travellers.

For travellers, it can be concluded that the biggest challenge is within the use of sustainable private transportation. Young $(<25)$ and elderly $(>65)$ are already using sustainable public transportation, but the age group in between (25-65) are dominant car users, and it will take effort to move them towards sustainable mobility.

From this research it can be concluded that the current travel behaviour of the people in the Achterhoek is not very sustainable. Dominant car use, little use of public transportation and indispensability of cars according to respondents will be a challenge for governments and operators when it comes to implementation of sustainable mobility. Travellers do not play a big role in most of the policies of governments and transport operators. However, as mobility is all about someone's ability to travel from origin to destination with a certain travel mode, the travellers should also have a place in the whole transition towards sustainable mobility. Therefore, the biggest challenge is to change the travellers travel behaviour into sustainable travel behaviour.

\subsection{RECOMMENDATIONS FOR FUTURE RESEARCH}

This study focussed on sustainable mobility in rural areas, like the Achterhoek. The data and information used in this study is very specific for this study area in the Netherlands. Therefore, it is recommended to repeat this (or a similar) study for other peri-urban and rural areas. Especially the implementation of policies regarding sustainable mobility need consideration as this research showed that policymakers do not know how to realise sustainable mobility. In addition, the role of mobility and transportation within the overall environmental policies and management of governments might be an important area for future research.

As mentioned in the discussion, Bleijenberg (2012) advised to research the spatial structure regarding travel behaviour, because the spatial structure could affect the choice for sustainable mobility. Moreover, a wider spatial-focussed research considering sustainable mobility could be interesting. Another recommendation is to include social characteristics, life cycle stages and household types in similar research, and for the development of policies.

As a spatial planner, I have learned that working together with many disciplines, stakeholders and spatial structures is hard, but also necessary to come to a successful implementation of spatial design and its utilities. Therefore, I would like to emphasize the need for a holistic view on implementing sustainable mobility. Implementation might be easier when it is already included in the spatial development plan for new housing, work locations and recreation, and when it plays a key role within the spatial development. 


\section{REFERENCES}

8RHK. (2019). Achterhoek Visie 2030. Retrieved from https://8rhk.nl/wp-content/uploads/2019/06/8rhkvisie-2030_brochure.pdf

8RHK Ambassadeurs. (n.d.). 8RHK. Retrieved November 25, 2020, from https://8rhk.nl/

Ahmed, S., Adnan, M., Janssens, D., \& Wets, G. (2020). A personalized mobility based intervention to promote pro-environmental travel behavior. Sustainable Cities and Society, 62, 102397. https://doi. org/10.1016/j.scs.2020.102397

Arriva. (2020). CO2-beleid. Retrieved February 16, 2021, from https://www.arriva.nl/meer-arriva/onzeambities/klimaat-ambities/route-duurzaamheid.htm

Arriva. (2021). Arriva Rivierenland Vervoerplan 2020-2021 Arriva Rivierenland. Retrieved from https://www. rocovgelderland.nl/download/adviezen/310

Banister, D. (2005). Unsustainable transport: City transport in the new century. In Unsustainable Transport:

City Transport in the New Century. https://doi.org/10.4324/9780203003886

Banister, D. (2008). The sustainable mobility paradigm. 15, 73-80. https://doi.org/10.1016/j. tranpol.2007.10.005

Barr, S., \& Prillwitz, J. (2014). A Smarter Choice? Exploring the Behaviour Change Agenda for

Environmentally Sustainable Mobility. Environment and Planning C: Government and Policy, 32(1), 1-19. https://doi.org/10.1068/c1201

Bartle, C., \& Chatterjee, K. (2019). Employer perceptions of the business benefits of sustainable transport: A case study of peri-urban employment areas in South West England. Transportation Research Part A: Policy and Practice, 126, 297-313. https://doi.org/10.1016/j.tra.2019.04.012

Bastiaansen, J., Donkers, H., \& Martens, K. (2013). Vervoersarmoede door sociale uitsluiting. Geografie, 6-10.

Berger, G., Feindt, P. H., Holden, E., \& Rubik, F. (2014, July 1). Sustainable Mobility-Challenges for a Complex Transition. Journal of Environmental Policy and Planning, Vol. 16, pp. 303-320. https://doi.org/10. 1080/1523908X.2014.954077

Black, W. R. (2010). Sustainable Transportation: Problems and Solutions. Retrieved from https:// books.google.nl/books?id=ijc9SlvmZDUC\&printsec=frontcover\&hl=nl\&source=gbs_ge_

summary_r\&cad $=0 \# v=$ onepage $\& q \& f=f a l s e$

Bleijenberg, A. (2012). The Attractiveness of Car Use. In Cars and Carbon (pp. 19-42). https://doi. org/10.1007/978-94-007-2123-4

Boisjoly, G., \& El-Geneidy, A. M. (2017). The insider: A planners' perspective on accessibility. Journal of Transport Geography, 64(July), 33-43. https://doi.org/10.1016/j.jtrangeo.2017.08.006

Brůhová Foltýnová, H., Vejchodská, E., Rybová, K., \& Květoň, V. (2020). Sustainable urban mobility: One definition, different stakeholders' opinions. Transportation Research Part D: Transport and Environment, 87, 102465. https://doi.org/10.1016/j.trd.2020.102465

Brussel, M. (2020). Transport Equity and Assessibility. Retrieved from https://canvas.utwente.nl/ courses/5258/files/1580028/download?wrap $=1$

Bryman, A. (2012). Social research methods (4th ed.). Retrieved from https://www.google. $\mathrm{com} / \mathrm{url}$ ?sa $=\mathrm{t} \& \mathrm{rct}=\mathrm{j} \& \mathrm{q}=\& \mathrm{esrc}=\mathrm{s} \&$ source $=$ web\&cd $=\& \mathrm{cad}=\mathrm{rja} \& u a c t=8 \& \mathrm{ved}=2 \mathrm{ahUKEwjf}$ h50nmsvuAhXS3KQKHSo8AFEQFjABegQIAhAC\&url=https\%3A\%2F\%2Fwww.researchgate.

net\%2Fprofile\%2FYousef_Shahwan4\%2Fpost\%2FWhat_is_the_best_and_the_most_recent_book_in_medica Bureau Spoorbouwmeester. (2012). Het Stationsconcept. Retrieved from https://www.spoorbeeld.nl/beleid/ station\#node-95-0

Castillo, H., \& Pitfield, D. E. (2010). ELASTIC - A methodological framework for identifying and selecting sustainable transport indicators. Transportation Research Part D: Transport and Environment, 15(4), 179-188. https://doi.org/10.1016/j.trd.2009.09.002

CBS / Rijkswaterstaat (RWS) (2014a): Onderzoek Verplaatsingen in Nederland 2010 - OViN 2010 versie 2.0.

DANS. https://doi-org.ezproxy2.utwente.nl/10.17026/dans-zhs-ghwg

CBS / Rijkswaterstaat (RWS) (2014b): Onderzoek Verplaatsingen in Nederland 2011 - OViN 2011 versie 2.0.

DANS. https://doi-org.ezproxy2.utwente.nl/10.17026/dans-xv2-hapb

CBS / Rijkswaterstaat (RWS) (2014c): Onderzoek Verplaatsingen in Nederland 2012 - OViN 2012 versie 2.0.

DANS. https://doi-org.ezproxy2.utwente.nl/10.17026/dans-2bs-q7u2

CBS / Rijkswaterstaat (RWS) (2014d): Onderzoek Verplaatsingen in Nederland 2013 - OViN 2013. DANS. https:// 
doi-org.ezproxy2.utwente.nl/10.17026/dans-x9h-dsdg

CBS. (2015a). Onderzoek Verplaatsingen in Nederland 2010. 39. Retrieved from https://easy.dans.knaw.nl/ui/ datasets/id/easy-dataset:61643

CBS; Rijkswaterstaat (RWS) (2015b): Onderzoek Verplaatsingen in Nederland 2014 - OViN 2014. DANS. https:// doi-org.ezproxy2.utwente.nl/10.17026/dans-x95-5p7y

CBS; Rijkswaterstaat (RWS) (2017a): Onderzoek Verplaatsingen in Nederland 2015 - OViN 2015 versie 2.0.

DANS. https://doi-org.ezproxy2.utwente.nl/10.17026/dans-z2v-c39p

CBS; Rijkswaterstaat (RWS) (2017b): Onderzoek Verplaatsingen in Nederland 2016 - OViN 2016. DANS. https:// doi-org.ezproxy2.utwente.nl/10.17026/dans-293-wvf7

CBS; Rijkswaterstaat (RWS) (2017c): Onderzoek Verplaatsingen in Nederland 2017 - OViN 2017. DANS. https:// doi-org.ezproxy2.utwente.nl/10.17026/dans-xxt-9d28

CBS. (2018a, July 2). StatLine - Personenmobiliteit; persoonskenmerken en vervoerwijzen, regio, 2010-2017.

Retrieved September 14, 2020, from https://opendata-cbs-nl.ezproxy2.utwente.nl/\#/CBS/nl/dataset/83499NED/ table

CBS; Rijkswaterstaat (RWS) (2018b): Onderzoek Onderweg in Nederland - ODiN 2018. DANS. https://doi-org. ezproxy2.utwente.nl/10.17026/dans-xn4-q9ks

CBS. (2019a). Huishoudens naar inkomen en autobezit per PC5-gebied. Retrieved June 1, 2020, from https:// www.cbs.nl/nl-nl/maatwerk/2019/23/huishoudens-naar-inkomen-en-autobezit-per-pc5-gebied

CBS. (2019b, September 10). StatLine - Regionale prognose 2020-2050; bevolkingsontwikkeling, regio-indeling 2018. Retrieved September 16, 2020, from https://opendata-cbs-nl.ezproxy2.utwente.nl/statline/\#/CBS/nl/ dataset/84528NED/table?ts $=1600263573073$

CBS. (2020a). Afstand tot treinstation, autobezit per wijk. Retrieved June 1, 2020, from https://www.cbs.nl/nl-nl/ maatschappij/verkeer-en-vervoer/ov-monitor/hoe-bereikbaar-is-het-ov/afstand-tot-treinstation-autobezit-per-wijk CBS. (2020b). Regionale kerncijfers Nederland. Retrieved May 15, 2020, from Statline website: https:// www.google.com/url?q=https://opendata.cbs.nl/statline/\%23/CBS/nl/dataset/70072ned/table?ts\%3D1 589546072824\&sa=D\&ust=1589960917980000\&usg=AFQjCNHrOLRkiOLGLlaxPOCXwJMq7kVzCg CBS. (2020c). StatLine - Bevolkingsontwikkeling; regio per maand. Retrieved September 16, 2020, from Statl website: https://opendata-cbs-nl.ezproxy2.utwente.nl/statline/\#/CBS/nl/dataset/37230ned/table?fromstatweb CBS; Rijkswaterstaat (RWS-WVL) (2020d): ODiN 2019. DANS. https://doi-org.ezproxy2.utwente.nl/10.17026/ dans-xpv-mwpg

Chatterjee, K., \& Scheiner, J. (2015). Understanding changing travel behaviour over the life course: Contributions from biographical research. 14th International Conference on Travel Behaviour Research, 1-36. Retrieved from https://uwe-repository.worktribe.com/OutputFile/831138

Christiansen, P., Engebretsen, O., Fearnley, N., \& Usterud Hanssen, J. (2017). Parking facilities and the built environment: Impacts on travel behaviour. Transportation Research Part A: Policy and Practice, 95, 198-206. https://doi.org/https://doi-org.ezproxy2.utwente.nl/10.1016/j.tra.2016.10.025

Delbosc, A., McDonald, N., Stokes, G., Lucas, K., Circella, G., \& Lee, Y. (2019). Millennials in cities: Comparing travel behaviour trends across six case study regions. Cities, 90, 1-14. https://doi.org/10.1016/j.

cities.2019.01.023

Dickinson, J., Kingham, S., Copsey, S., \& Hougie, D. (2003). Employer travel plans, cycling and gender: will travel plan measures improve the outlook for cycling to work in the UK? Transport Research Part D: Transport and Environment, 8(1), 53-67. https://doi.org/https://doi.org/10.1016/S1361-9209(02)00018-4

Dinning, M., \& Weisenberger, T. (2017). Multimodal Transportation Payments Covergence - Key to Mobility. In G. Meyer \& S. Shaheen (Eds.), Disrupting Mobility (pp. 121-133). https://doi.org/10.1007/978-3-319-51602-8_8 Docherty, I., Marsden, G., \& Anable, J. (2018). The governance of smart mobility. Transportation Research Part A: Policy and Practice, 115, 114-125. https://doi.org/10.1016/j.tra.2017.09.012

Fagnant, D. J., \& Kockelman, K. (2015). Preparing a nation for autonomous vehicles: Opportunities, barriers and policy recommendations. Transportation Research Part A: Policy and Practice, 77, 167-181. https://doi. org/10.1016/j.tra.2015.04.003

Farla, J., Alkemade, F., \& Suurs, R. A. A. (2010). Analysis of barriers in the transition toward sustainable mobility 
in the Netherlands. Technological Forecasting and Social Change, 77(8), 1260-1269. https://doi.org/10.1016/j. techfore.2010.03.014

Geurs, K. T., \& Wee, B. Van. (2004). Accessibility evaluation of land-use and transport strategies : review and research directions. 12, 127-140. https://doi.org/10.1016/j.jtrangeo.2003.10.005

Gironés, E. S., \& Vrščaj, D. (2018). Who Benefits from Smart Mobility Policies? The Social Construction of Winners and Losers in the Connected Bikes Projects in the Netherlands. In Governance of the Smart Mobility Transition (pp. 85-101). https://doi.org/10.1108/978-1-78754-317-120181006

Hamidi, Z., \& Zhao, C. (2020). Shaping sustainable travel behaviour: Attitude, skills, and access all matter. Transportation Research Part D: Transport and Environment, 88, 102566. https://doi.org/10.1016/j. $\operatorname{trd} .2020 .102566$

Hidding, M. (2006). Planning voor Stad en Land. Bussum: Coutinho.

Hofs, Y. (2019, October 18). Bij ons in de Achterhoek loopt het openbaar vervoer vast in de bereikbaarheid - Trikker. Retrieved September 10, 2020, from https://trikker.nl/bij-ons-in-de-achterhoek-loopt-het-openbaarvervoer-vast-in-de-bereikbaarheid/?unapproved=3372\&moderation-hash=bcdefc7892bd5e143d0d9c85f085aO 10\#comment-3372

Holden, E., Banister, D., Gössling, S., Gilpin, G., \& Linnerud, K. (2020, July 1). Grand Narratives for sustainable mobility: A conceptual review. Energy Research and Social Science, Vol. 65, p. 101454. https://doi. org/10.1016/j.erss.2020.101454 Jeon, C. M., \& Amekudzi, A. (2005). Addressing Sustainability in Transportation Systems: Definitions, Indicators, and Metrics. Journal of Infrastructure Systems, 11(1), 31-50. https://doi.org/10.1061/(ASCE)10760342(2005)11:1(31)

Julsrud, T. E. (2014). Activity-Based Patterns of Everyday Mobility: The Potential for Long-Term Behaviour Change Across Five Groups of Travellers. Journal of Environmental Policy \& Planning, 16(3), 401-417. https://doi.org/10 $.1080 / 1523908 X .2013 .837380$

Kamargianni, M., Matyas, M., Li, W., \& Schäfer, A. (2015). Feasability study for "Mobility as a Service" concept in London. Retrieved from https://www-researchgate-net.ezproxy2.utwente.nl/profile/Maria Kamargianni/publication/279957542_Feasibility_Study_for_Mobility_as_a_Service_concept_in_London/ links/559fc6dc08aeOeObf613fd34/Feasibility-Study-for-Mobility-as-a-Service-concept-in-London.pdf Knutsson, T. B. (2010). Urban Mobility in the 21 st Century. Blekinge Tekniska Högskola.

Kritiek op busvervoer in Achterhoek door Arriva. (2012, November 20). Twentsche Courant Tubantia. Retrieved from https://advance-lexis-com.ezproxy2.utwente.nl/document/?pdmfid=1516831\&crid=b49f5b7a-c1c5-433399cc-7a64f55658c6\&pddocfullpath=\%2Fshared\%2Fdocument\%2Fnews\%2Furn\%3Acontentltem\%3A573FM7M1-DYRY-N3PK-00000-00\&pdcontentcomponentid=258884\&pdteaserkey=sr 1 \&pdita Kumar, R. (2011). Research Methodology (Third). Cornwall: SAGE Publications.

Le Vine, S., \& Polak, J. (2015, May 1). Introduction to special issue: new directions in shared-mobility research. Transportation, Vol. 42, pp. 407-411. https://doi.org/10.1007/s11116-015-9603-4

Liu, X., Yu, J., Trisha, S., \& Beimborn, E. (2020). Exploring the feasibility of mobility as a service in small urban and rural communities: Lessons from a case study. Journal of Urban Planning and Development, 146(3). https:// doi.org/10.1061/(ASCE)UP.1943-5444.0000600

Lund, E., Kerttu, J., \& Koglin, T. (2017). Drivers and Barriers for Integrated Mobility Services. Retrieved from http://www.k2centrum.se/sites/default/files/drivers_and_barriers_for_integrated_mobility_services_k2_working_ paper_2017_3.pdf

Marshall, S. (2001). The challenge of sustainable transport. In A. Laynard, S. Davoudi, \& S. Batty (Eds.), Planning for a Sustainable Future (first). Retrieved from https://books.google.nl/books?hl=nl\&lr=\&id=qrbyfm82yuMC\&oi $=$ fnd\&pg $=P A 131 \& d q=$ the+challenge+of+sustainable+transport\&ots=AJRqkICgeY\&sig= Q7dOh9tzQcl92M U7QdboF9ENANQ\&redir_esc $=y \# v=$ onepage $\& q=$ the challenge of sustainable transport\&f=false Martens, K. (2017). Transport Justice Designing Fair Transportation Systems (First). New York: Routledge. McCormick, K., Anderberg, S., Coenen, L., \& Neij, L. (2013). Advancing sustainable urban transformation. Journal of Cleaner Production, 50, 1-11. https://doi.org/10.1016/j.jclepro.2013.01.003

Milbourne, P., \& Kitchen, L. (2014). Rural mobilities: Connecting movement and fixity in rural places. Journal of 
Rural Studies, 34, 326-336. https://doi.org/10.1016/j.jurstud.2014.01.004

Ministerie van Infrastructuur en Waterstaat. (2019). Een grote en urgente opgave | Contouren Toekomstbeeld OV 2040 | Specials. Retrieved February 17, 2021, from https://magazines.rijksoverheid.nl/ienw/ienwspecials/2019/07/een-grote-en-urgente-opgave

Ministerie van Infrastructuur en Waterstaat. (2021). Toekomstperspectief Automobiliteit 2040. Retrieved from https://www.rijksoverheid.nl/onderwerpen/mobiliteit-nu-en-in-de-toekomst/documenten/rapporten/2021/01/14/ bijlage-1-toekomstperspectief-automobiliteit-ienw

Mitchell, C. (1995). Definitions of accessibility. Cranfield Institute of Technology. Retrieved from https://trid-trborg.ezproxy2.utwente.nl/view/716768

Morency, C. (2013, February 11). Sustainable Mobility: definitions, concepts and indicators | Mobile Lives Forum. Retrieved June 14, 2020, from Mobile Lives Forum website: https://en.forumviesmobiles.org/video/2013/02/12/ sustainable-mobility-definitions-concepts-and-indicators-622

Mounce, R., Beecroft, M., \& Nelson, J. D. (2020). On the role of frameworks and smart mobility in addressing the rural mobility problem. Research in Transportation Economics. https://doi.org/10.1016/j.retrec.2020.100956 Mulley, C., \& Kronsell, A. (2018). The "uberisation " of public transport and mobility as a service ( MaaS ): Implications for future mainstream public transport. Research in Transportation Economics, (xxxx), O-1. https:// doi.org/10.1016/j.retrec.2018.08.007

Nikitas, A., Kougias, I., Alyavina, E., \& Njoya Tchouamou, E. (2017). How Can Autonomous and Connected Vehicles, Electromobility, BRT, Hyperloop, Shared Use Mobility and Mobility-As-A-Service Shape Transport Futures for the Context of Smart Cities? Urban Science, 1(36), 1-21. https://doi.org/10.3390/urbansci 1040036 Pereira, R. H. M., Schwanen, T., \& Banister, D. (2017). Distributive justice and equity in transportation. Transport Reviews, 37(2), 170-191. https://doi.org/10.1080/01441647.2016.1257660

Piorr, A., Ravetz, J., \& Tosics, I. (2011). Peri-urbanisation in Europe (A. Piorr, Ed.). Retrieved from http://www. openspace.eca.ed.ac.uk/wp-content/uploads/2015/12/Peri_Urbanisation_in_Europe_printversion.pdf Porru, S., Misso, F. E., Pani, F. E., \& Repetto, C. (2020). Smart mobility and public transport: Opportunities and challenges in rural and urban areas. Journal of Traffic and Transportation Engineering (English Edition), 7(1), 88-97. https://doi.org/10.1016/j.jtte.2019.10.002

Preston, J., \& Rajé, F. (2007). Accessibility, mobility and transport-related social exclusion. Journal of Transport Geography, 15(3), 151-160. https://doi.org/10.1016/j.jtrangeo.2006.05.002

Prillwitz, J., \& Barr, S. (2011). Moving towards sustainability ? Mobility styles , attitudes and individual travel behaviour. Journal of Transport Geography, 19(6), 1590-1600. https://doi.org/10.1016/j.jtrangeo.2011.06.011 Provincie Gelderland. (2020). Visie voor een bereikbaar Gelderland. Retrieved from https://www.gelderland.nl/ mobiliteitsvisie

Pucher, J., \& Renne, J. L. (2005). Rural mobility and mode choice: Evidence from the 2001 National Household Travel Survey. Transportation, 32(2), 165-186. https://doi.org/10.1007/s11116-004-5508-3

Rafika, K., Rym, K., Souad, S. B., \& Youcef, L. (2016). A Public Actor Awareness for Sustainable Development. Procedia - Social and Behavioral Sciences, 216(October 2015), 151-162. https://doi.org/10.1016/j.

sbspro.2015.12.022

Salonen, M., Broberg, A., Kyttä, M., \& Toivonen, T. (2014). Do suburban residents prefer the fastest or low-carbon travel modes? Combining public participation GIS and multimodal travel time analysis for daily mobility research. Applied Geography, 53, 438-448. https://doi.org/10.1016/j.apgeog.2014.06.028

Schiller, P. L., \& Kenworthy, J. R. (2017). An Introduction to Sustainable Transportation (2nd ed.). Retrieved from https://www-taylorfrancis-com.ezproxy2.utwente.nl/books/introduction-sustainable-transportation-prestonschiller-jeffrey-kenworthy/10.4324/9781315644486

Scoones, l., Leach, M., \& Newell, P. (2015). The Politics of Green Transformations (First; I. Scoones, M. Leach, \& P. Newell, Eds.). Abingdon: Routledge.

Shaheen, S., Cohen, A., \& Zohdy, I. (2016). Shared Mobility: Current Practices and Guiding Principles. In U.S. Department of Transportation.

Shergold, I., \& Parkhurst, G. (2010). Operationalising "sustainable mobility": the case of transport policy for older citizens in rural areas. Journal of Transport Geography, 18, 336-339. https://doi.org/10.1016/j. 
jtrangeo.2009.08.002

Sitanyiová, D., \& Misso, F. E. (2019). RUMOBIL - Feasibility of New Public Transport Services in European

Rural Areas. IOP Conference Series: Materials Science and Engineering, 1-11. https://doi.org/10.1088/1757899X/661/1/01214

Soder, M., \& Peer, S. (2017). The potential role of employers in promoting sustainable mobility in rural areas: Evidence from Eastern Austria*. Https://Doi-Org.Ezproxy2.Utwente.NI/10.1080/15568318.2017.1402974. https://doi.org/10.1080/15568318.2017.1402974

Staat van het OV - CROW. (2018). Retrieved September 7, 2020, from CROW website: https://www.crow.nl/staatvan-het-ov/jaargangen/2018/reizigers/instappers/2018

Steenbekkers, A., Simon, C., Vermeij, L., \& Spreeuwers, W.-J. (2008). Het platteland van alle Nederlanders.

Retrieved from http://docplayer.nl/16292351-Het-platteland-van-alle-nederlanders.html

Taylor, B. D., \& Kalauskas, R. (2010). Addressing Equity in Political Debates over Road Pricing: Lessons from

Recent Projects. Transportation Research Record: Journal of the Transportation Research Board, (2187), 44-52. https://doi.org/https://doi-org.ezproxy2.utwente.nl/10.3141\%2F2187-07

Tian, N., Tang, S., Che, A., \& Wu, P. (2020). Measuring regional transport sustainability using super-efficiency SBM-DEA with weighting preference. Journal of Cleaner Production, 242, 118474. https://doi.org/10.1016/j. jclepro.2019.118474

Van Goevorden, C., Rietveld, P., Koelemeijer, J., \& Peeters, P. (2006). Subsidies in public transport. European Transport, 32, 5-25. Retrieved from https://www.openstarts.units.it/bitstream/10077/5892/1/vanGoeverden_et_ al_ET32.pdf

Van Putten, B. (2020). Geen eigen auto of fiets meer - en toch altijd vervoer; Vervoer Van step tot streekbus: de vervoersapp van de toekomst kiest uit álle opties de beste rit Carrière \& geld. NRC, p. Economie 8-9. Retrieved from https://advance-lexis-com.ezproxy2.utwente.nl/document/?pdmfid=1516831\&crid=2b329382-5f51-450f9e39-4ac7b509ea9d\&pddocfullpath=\%2Fshared\%2Fdocument\%2Fnews\%2Furn\%3Acontentltem\%3A5Y4GHOF1-JC5G-14CT-00000-00\&pdcontentcomponentid=300171\&pdteaserkey=srO\&pdita

Vlek, C., Jager, W., \& Steg, L. (1997). Modellen en strategieën voor gedragsverandering ter beheersing van collectieve risico's. Nederlands Tijdschrift Voor de Psychologie, 52, 174-191.

VNG. (n.d.). Factsheet Mobiliteit | VNG. Retrieved from https://vng.nl/artikelen/factsheet-mobiliteit

VNG. (2019). Regionale Mobiliteitsprogramma's Regionale Mobiliteitsprogramma 's. (november), 1-37.

Retrieved from https://vng.nl/sites/default/files/2020-01/handreiking-1.0-regionale-mobiliteitsprogrammas.pdf $\% \mathrm{OA}$

Wegener, M., \& Fürst, F. (1999). Land-Use Transport Interaction : State of the Art. SSRN Electronic Journal, (October). https://doi.org/10.2139/ssrn.1434678

Wong, Y. Z., Hensher, D. A., \& Mulley, C. (2018). Emerging transport technologies and the modal efficiency framework: A case for mobility as a service (MaaS). Retrieved from https://ses.library.usyd.edu.au/ handle/2123/19100

Zhang, J., \& Van Acker, V. (2017, October 1). Life-oriented travel behavior research: An overview. Transportation Research Part A: Policy and Practice, Vol. 104, pp. 167-178. https://doi.org/10.1016/j.tra.2017.06.004 
Images

p2 https://wdcinsights.wordpress.com/2020/03/05/submission-to-the-review-of-sustainable-mobility-policy/

p9 https://media.itsnicethat.com/images/5cc6ca3f7fa44c8e69000016.format-webp.width1440_64xYPaabjSfLfYCd.webp

p44 https://media.itsnicethat.com/images/5cc6ca797fa44c1298002223.format-webp.width1440_8RIkcuHk6ip7dRXE.webp

p52 https://www.mdbs.nl/media/36395/duurzame_moniliteit_logo_thumb_800.jpg 


\section{APPENDIX}

A. Research Matrix 63

B. COROP Regions 66

C. Informed Consent 68

D. Survey Questions 69

E. Filter, correction and coding rules 75

F. Interview topic list 76

G. Motives per transport mode and distance 78

H. Code report 80 


\section{A. RESEARCH MATRIX}

\begin{tabular}{|c|c|c|c|c|}
\hline 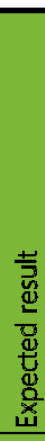 & 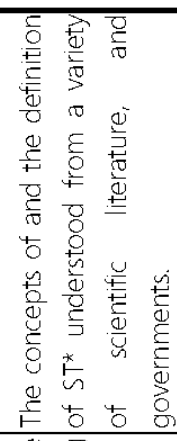 & 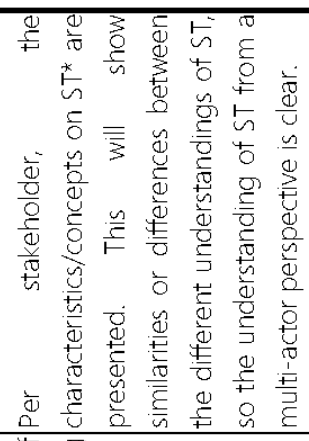 & 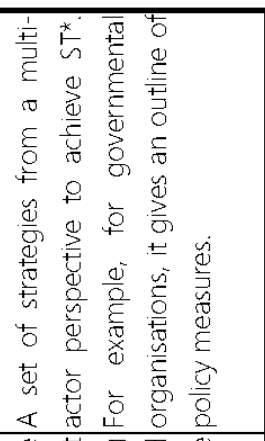 & 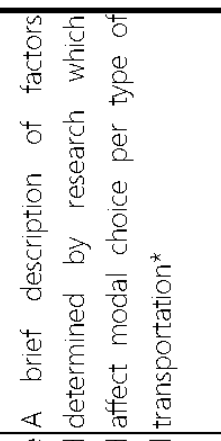 \\
\hline 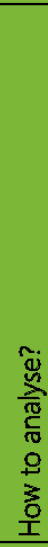 & 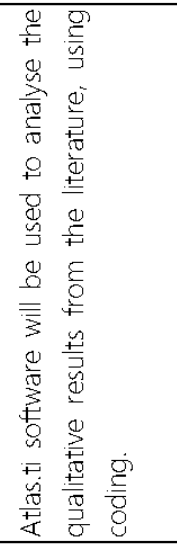 & 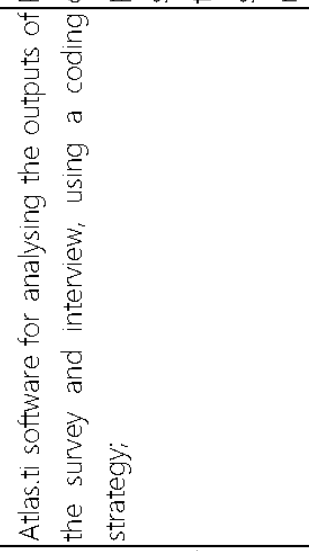 & 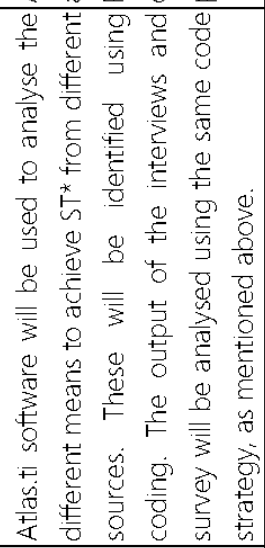 & 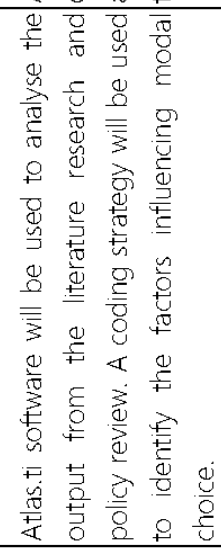 \\
\hline 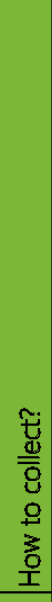 & 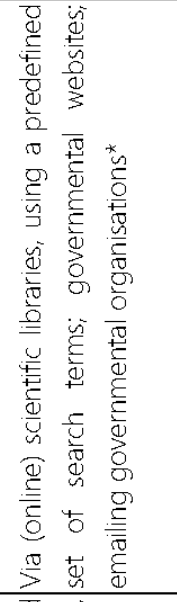 & 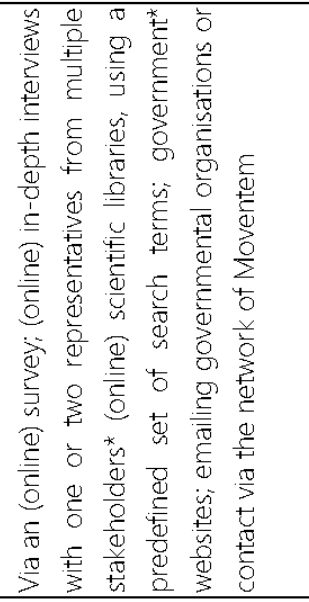 & 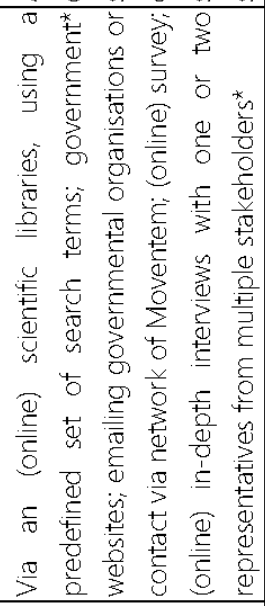 & 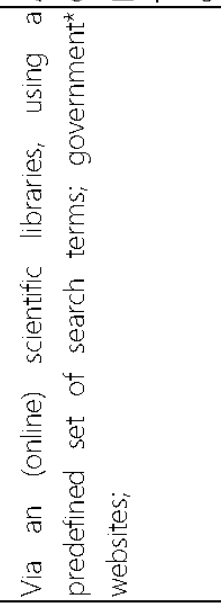 \\
\hline 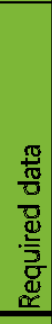 & 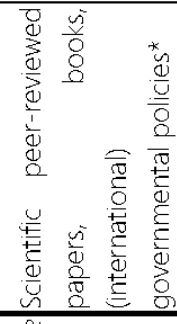 & 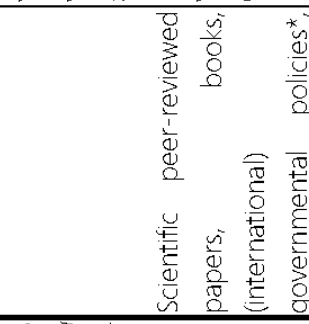 & 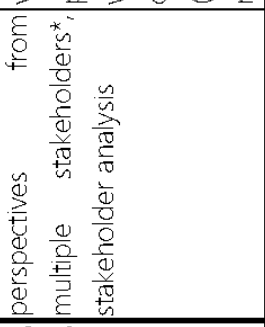 & 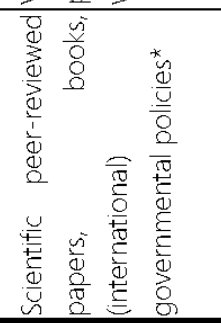 \\
\hline$\underset{\mathbb{X}}{\mathbb{X}}$ & 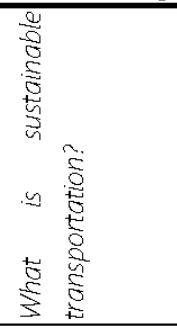 & 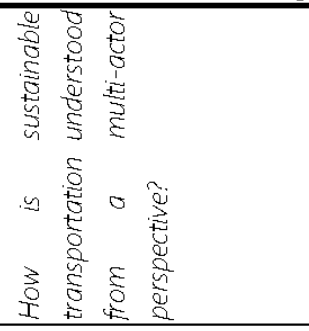 & 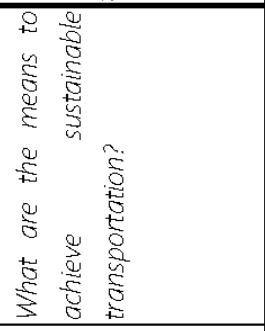 & 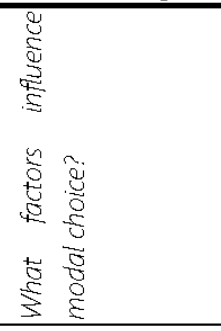 \\
\hline $\begin{array}{l}\text { : } \\
\text { : } \\
0\end{array}$ & \multicolumn{3}{|c|}{ uoleł } & 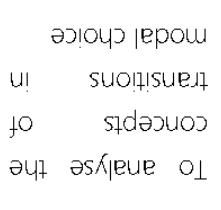 \\
\hline
\end{tabular}




\begin{tabular}{|c|c|c|c|c|c|}
\hline & 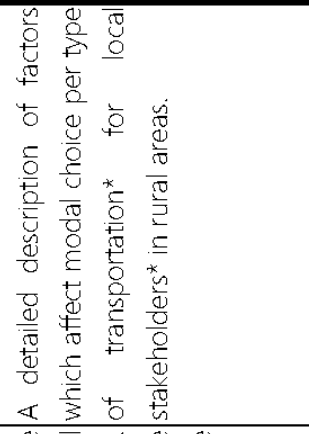 & 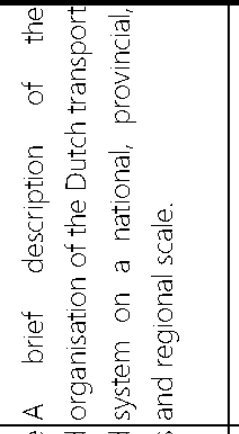 & 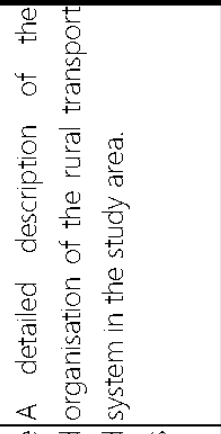 & 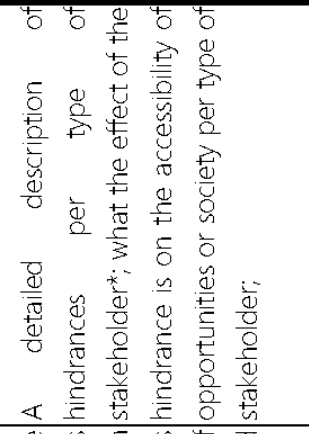 & 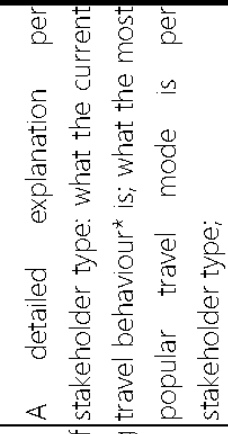 \\
\hline & 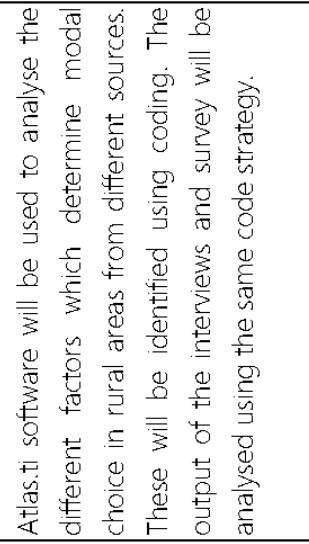 & 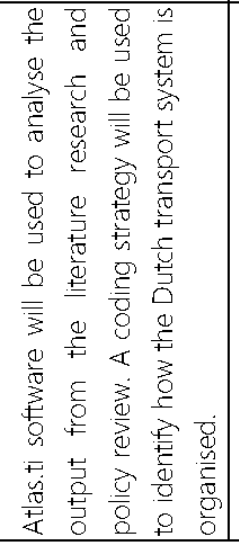 & 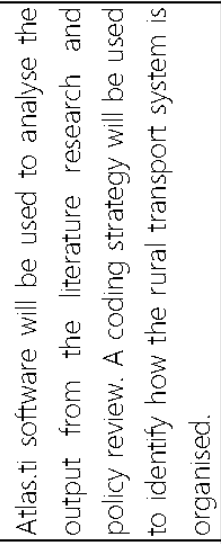 & 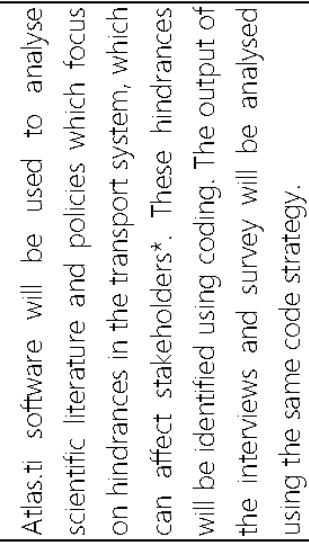 & 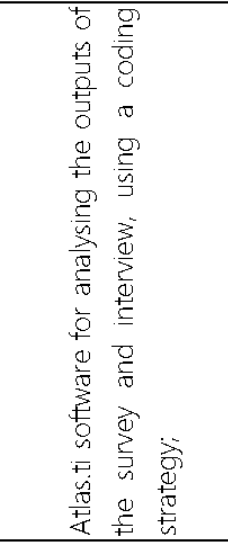 \\
\hline & 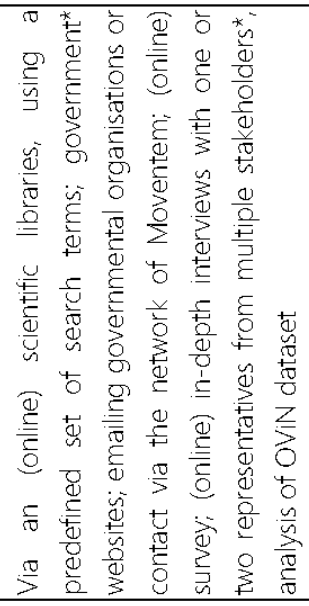 & 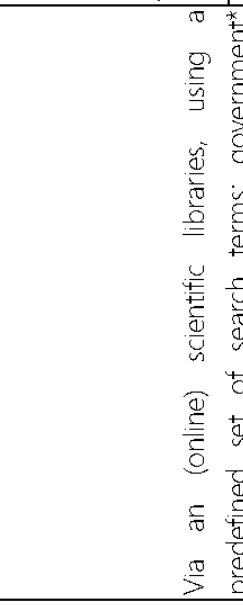 & 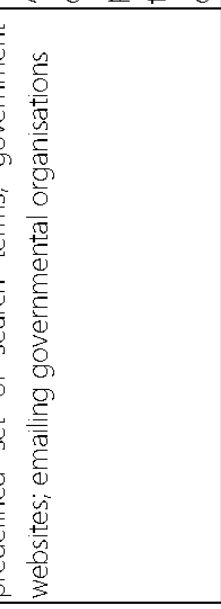 & 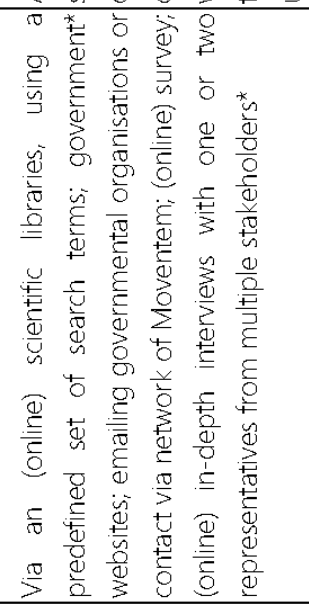 & 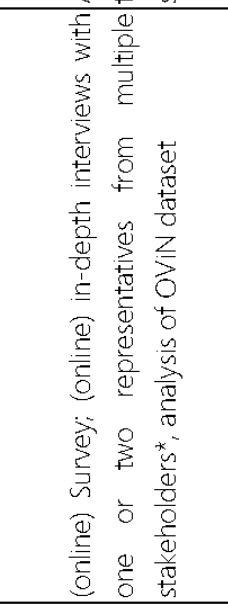 \\
\hline & 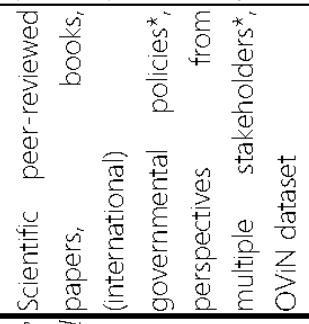 & & 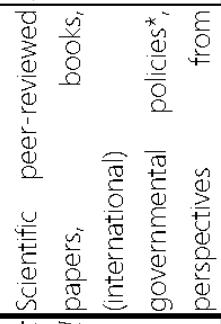 & 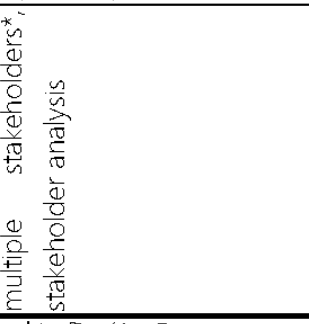 & 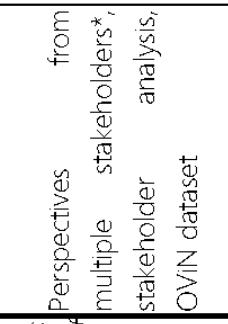 \\
\hline$\underline{\underline{x}}$ & 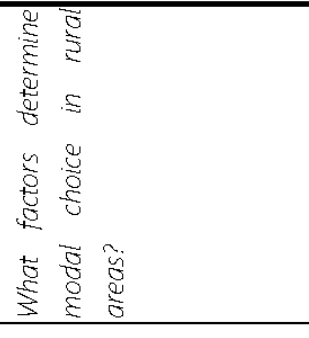 & 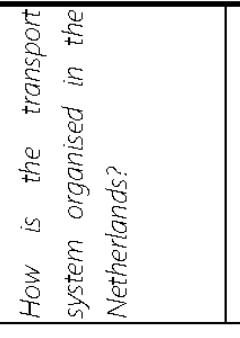 & 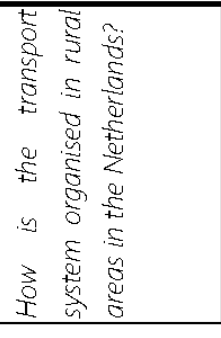 & 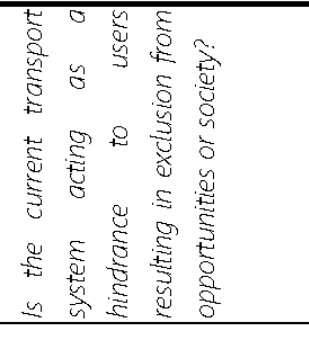 & 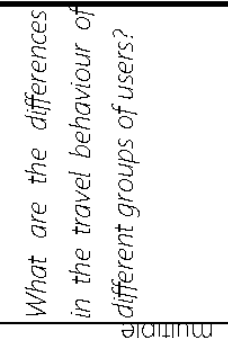 \\
\hline & & \multicolumn{3}{|c|}{ 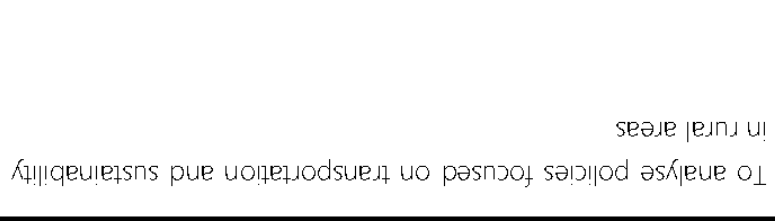 } & 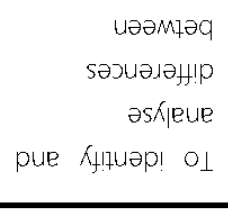 \\
\hline
\end{tabular}




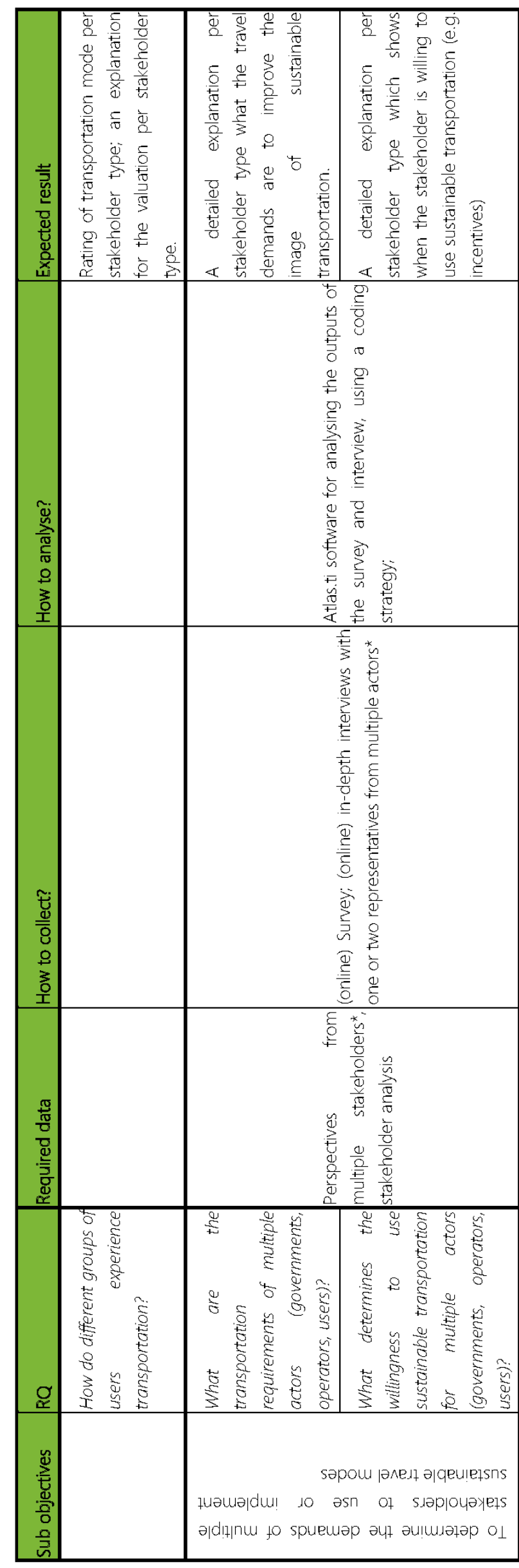

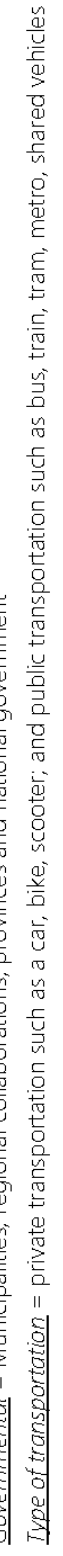


B. COROP REGIONS

Code ODiN $2019 \quad$ C o d e label ODiN 2019

1 Oost-Groningen

2 Delfzijl en omgeving

3 Overig Groningen

$4 \quad$ Noord-Friesland

5 Zuidwest-Friesland

6 Zuidoost-Friesland

7 Noord-Drenthe

8 Zuidoost-Drenthe

9 Zuidwest-Drenthe

10 Noord-Overijssel

11 Zuidwest-Overijssel

12 Twente

13 Veluwe

14 Achterhoek

15 Arnhem/Nijmegen

16 Zuidwest-Gelderland

17 Utrecht

18 Kop van Noord-Holland

19 Alkmaar en omgeving

20 IJmond

21 Agglomeratie Haarlem

22 Zaanstreek

23 Groot-Amsterdam

24 Het Gooi en Vechtstreek

25 Agglomeratie Leiden en

Bollenstreek

26 A g g lom eratie

's-Gravenhage

27 Delft en Westland

28 Oost-Zuid-Holland

29 Groot-Rijnmond

30 Zuidoost-Zuid-Holland

31 Zeeuwsch-Vlaanderen

32 Overig Zeeland

33 West-Noord-Brabant

34 Midden-Noord-Brabant

35 Noordoost-Noord-

Brabant

36 Zuidoost-Noord-Brabant

37 Noord-Limburg

38 Midden-Limburg

39 Zuid-Limburg

40 Flevoland 


\section{Indeling van Nederland in 40 copop-gebieden}

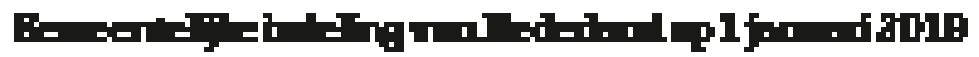
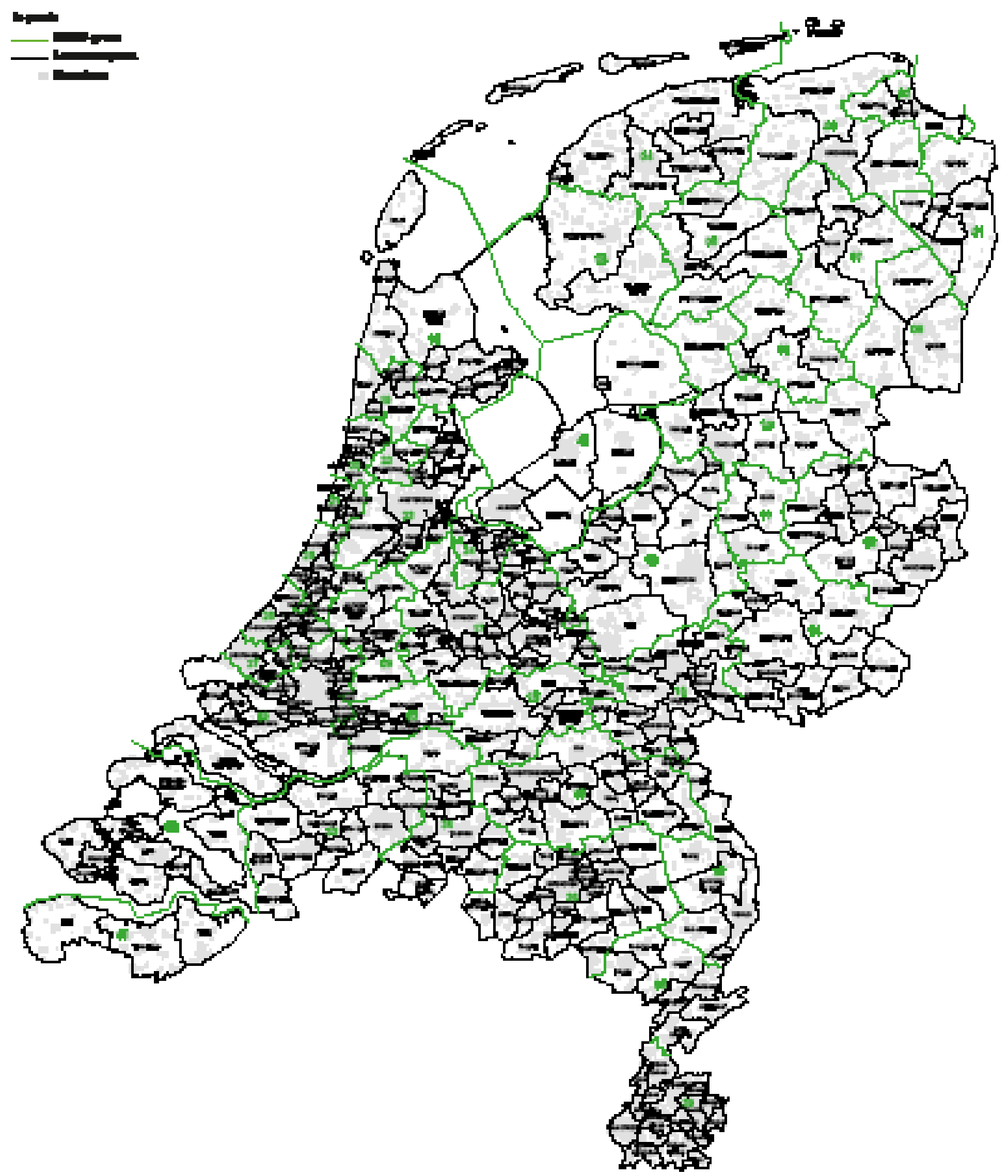


\title{
C. INFORMED CONSENT
}

\section{Consent Form for "Multi-actor challenges for development and implementation of sustainable mobility in rural areas in the Netherlands" YOU WILL BE GIVEN A COPY OF THIS INFORMED CONSENT FORM}

\begin{abstract}
Study Information
In this research "Multi-actor challenges for development and implementation of sustainable mobility in rural areas in the Netherlands" will be studied to identify the challenges for transportation users, public transport operators and governments (e.g. municipality, provinces) considering sustainable mobility. The answers given by respondents will be used to answer the research questions. The research will handle all data with care and according to the privacy law. The respondent can withdraw from this study at any moment.

Personal information will be collected, which are the postal code (e.g. 7000) where the respondent lives, the age of the respondent, occupation (e.g. student, working parttime / fulltime, retired) and the highest level of education. All this information will be anonymized and will not lead to a unique person. The data will be processed and saved during the research and will be deleted when the research is finished. During the research, only the researcher has access to the data. If you have any questions regarding this research you can contact s.w.m.wierenga@student.utwente.nl (researcher), m.j.g.brussel@utwente.nl (supervisor) or the ITC Ethics Committee ec-itc@utwente.nl
\end{abstract}

Please tick the appropriate boxes

Taking part in the study

I have read and understood the study information above, or it has been read to me. I have been able to ask questions (if applicable) about the study and my questions have been answered to my satisfaction.

I consent voluntarily to be a participant in this study and understand that I can refuse to answer questions and I can withdraw from the study at any time, without having to give a reason.

I understand that taking part in the study involves an audio-recorded interview. The recording will be transcribed as text and will be shared with the interviewee for approval. Both the recording and the transcribed text will not be shared outside the research team (researcher and supervisors). The recording and transcribed text will be deleted after the research is finished.

Use of the information in the study

I understand that information I provide will be used in the results of the research.

I understand that personal information collected about me that can identify me, such as my name or occupation, will not be shared beyond the study team.

I agree that my information can be quoted in research outputs. The researcher will first ask permission to write the specific quotes.

Consent to be Audio/video Recorded

I agree to be audio/video recorded.

\section{Signatures}

Name of participant

$\overline{\text { Signature }} \overline{\text { Date }}$




\section{SURVEY QUESTIONS}

\section{SURVEY QUESTIONS}

[Start scherm ]

Bedankt dat je de enquête wilt invullen. Met het invullen draagt $u$ bij aan mijn afstudeeronderzoek naar de kansen voor mobiliteit in het landelijk gebied in Nederland. Onder alle respondenten wordt $3 x$ een cadeaubon van $€ 50$ van Bol.com verloot. Aan het eind van deze enquête kunt $u$ hiervoor uw contactgegevens achterlaten. Het invullen van deze enquête duurt 10 tot 15 minuten.

De antwoorden van respondenten worden alleen gebruikt voor dit onderzoek. Het onderzoek is goedgekeurd door de Universiteit Twente/ITC. Er zal zorgvuldig worden omgaan met alle gegevens en de privacywet zal worden nageleefd. De respondent kan zich op elk moment terugtrekken uit dit onderzoek. Deelname aan dit onderzoek is anoniem en leidt niet tot een uniek persoon. De gegevens worden tijdens het onderzoek verwerkt en veilig bewaard. Tijdens het onderzoek heeft alleen de onderzoeker toegang tot deze data. Voor vragen over dit onderzoek kunt $u$ contact opnemen met s.w.m.wierenga@student.utwente.nl (onderzoeker),m.j.g.brussel@utwente.nl (supervisor) of de Ethische Commissie van Universiteit Twente/ITC ec-itc@utwente.nl

[Eind startscherm]

1. Welke vervoersmiddelen gebruikt u? [Meerdere antwoorden mogelijk]

- Lopend

- Fiets (niet-elektrisch)

- Elektrische fiets tot $25 \mathrm{~km} / \mathrm{uur}$

- Speed pedelec tot $45 \mathrm{~km} / \mathrm{uur}$

- Scooter/brommer

- Deelauto

- Auto (eigendom)

- Auto (lease)

- Bus

- Trein

- Regio taxi/ Zoov

- Overig

\section{Vragen over uw reisgedrag tot $5 \mathrm{~km}$ vóór Corona}

2. Welk vervoermiddel gebruikt $\mathrm{u}$ het meest voor deze reizen tot $5 \mathrm{~km}$ ? * Als u meerdere vervoersmiddelen gebruikt tijdens dezelfde reis (bijvoorbeeld fiets + trein), kies dan het vervoersmiddel waar u de meeste kilometers mee reist.

- Dropdown vervoersmiddelen

- Ik maak geen reizen tot $5 \mathrm{~km} \rightarrow$ door naar vraag 7

3. U gebruikt [insert antwooord 2] het meest als vervoermiddel voor reizen tot $5 \mathrm{~km}$. Wat is de reden dat $\mathrm{u}$ dit vervoermiddel het meest gebruikt? * [meerdere antwoorden mogelijk]

- Makkelijk

- Goedkoop 
- Gezond

- Snel

- Beter voor het milieu

- Samen reizen

- Anders, namelijk......

4. Zou $u$ deze reizen ook met een ander vervoermiddel kunnen doen (bijvoorbeeld op de fiets, lopend of met het openbaar vervoer)? *

- Ja, namelijk met... [open antwoord]

- Nee, omdat... [open antwoord]

5. Welk vervoermiddel gebruikt $\mathrm{u}$ het minst voor deze reizen tot $5 \mathrm{~km}$ ? * [ 1 antwoord mogelijk] [Dropdown met selecties vraag 1]

6. Wat is de reden dat $u$ dit vervoermiddel het minst gebruikt voor reizen tot $5 \mathrm{~km}$ ? * [meerdere antwoorden mogelijk]

- Moeilijk

- Niet beschikbaar

- Duur

- Ongezond

- Langzaam

- Slecht voor het milieu

- Ik kan niet samen reizen

- Anders, namelijk......

7. Kunt $u$ aangeven welk vervoermiddel $u$ het meest gebruikt per reismotief voor reizen tot $5 \mathrm{~km}$ ? [1 optie per reismotief] dropdown selectie

Als $u$ een reismotief niet heeft, klik dan op Niet van toepassing.

- Van en naar werk

[dropdown vervoersmiddelen] nvt

- Zakelijk / beroepsmatig

[dropdown vervoersmiddelen] nvt

- Onderwijs volgen

[dropdown vervoersmiddelen]

nvt

- Diensten / Persoonlijk

[dropdown vervoersmiddelen]

nvt

- Winkelen / Boodschappen doen

[dropdown vervoersmiddelen]

nvt

- Halen / brengen kinderen

[dropdown vervoersmiddelen]

nvt

- Sociaal/creatief

[dropdown vervoersmiddelen]

nvt

- Wandelen / toeren

[dropdown vervoersmiddelen]

nvt

\section{Vragen over uw reisgedrag tussen de $5 \mathrm{~km}$ en 15 km vóór Corona}

8. Welk vervoermiddel gebruikt $u$ het meest voor deze reizen tussen de $5 \mathrm{~km}$ en $15 \mathrm{~km}$ ? *

Als u meerdere vervoersmiddelen gebruikt tijdens dezelfde reis, kies dan het vervoersmiddel waar u de meeste kilometers mee reist.

- Dropdown vervoersmiddelen

- Ik maak geen reizen tussen de $5 \mathrm{~km}$ en $15 \mathrm{~km} \rightarrow$ door naar vraag 13

9. U gebruikt [insert antwoord 8] het meest als vervoermiddel voor reizen tussen de 5 en $15 \mathrm{~km}$. Wat is de reden dat $u$ dit vervoermiddel het meest gebruikt? * [meerdere antwoorden mogelijk]

- Makkelijk 
- Goedkoop

- Gezond

- Snel

- Beter voor het milieu

- Samen reizen

- Anders, namelijk.....

10. Zou u deze reizen ook met een ander vervoermiddel kunnen doen (bijvoorbeeld op de fiets, lopend of met het openbaar vervoer)? *

- Ja, namelijk met... [open antwoord]

- Nee, omdat... [open antwoord]

11. Welk vervoermiddel gebruikt $u$ het minst voor deze reizen tussen de $5 \mathrm{~km}$ en $15 \mathrm{~km}$ ? * [1 antwoord mogelijk]

[Dropdown met selecties vraag 1] - optie wandelen

12. Wat is de reden dat $u$ dit vervoermiddel het minst gebruikt voor reizen tussen de $5 \mathrm{~km}$ en $15 \mathrm{~km}$ ? * [meerdere antwoorden mogelijk]

- Moeilijk

- Niet beschikbaar

- Duur

- Ongezond

- Langzaam

- Slecht voor het milieu

- Ik kan niet samen reizen

- Anders, namelijk.....

13. Kunt $u$ aangeven welk vervoermiddel $u$ het meest gebruikt per reismotief voor reizen tussen de $5 \mathrm{~km}$ en $\underline{15 \mathrm{~km}}$ ? [1 optie per reismotief]

Als u een reismotief niet heeft, klik dan op Niet van toepassing.

- Van en naar werk

- Zakelijk / beroepsmatig

[dropdown vervoersmiddelen]

nvt

- Onderwijs volgen

[dropdown vervoersmiddelen]

nvt

- Diensten / Persoonlijk

[dropdown vervoersmiddelen]

nvt

- Winkelen / Boodschappen doen

[dropdown vervoersmiddelen]

nvt

- Halen / brengen kinderen

[dropdown vervoersmiddelen]

nvt

- Sociaal / creatief

[dropdown vervoersmiddelen]

nvt

- Wandelen / toeren

[dropdown vervoersmiddelen]

nvt

[dropdown vervoersmiddelen]

nvt

\section{Vragen over uw reisgedrag langer dan 20km vóór Corona}

14. Welk vervoermiddel gebruikt $\mathrm{u}$ het meest voor deze reizen langer dan $20 \mathrm{~km}$ ? *

Als u meerdere vervoersmiddelen gebruikt tijdens dezelfde reis, kies dan het vervoersmiddel waar $u$ de meeste kilometers mee reist.

- Dropdown vervoersmiddelen

- Ik maak geen reizen langer dan $20 \mathrm{~km} \rightarrow$ door naar vraag 19

15. U gebruikt [insert antwoord 14] het meest als vervoermiddel voor reizen langer dan $20 \mathrm{~km}$. Wat is de

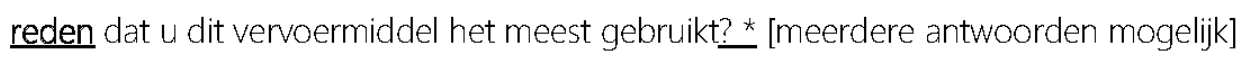


- Makkelijk

- Goedkoop

- Gezond

- Snel

- Beter voor het milieu

- Samen reizen

- Anders, namelijk.....

16. Zou u deze reizen ook met een ander vervoermiddel kunnen doen (bijvoorbeeld op de fiets, lopend of met het openbaar vervoer)? *

- Ja, namelijk met... [open antwoord]

- Nee, omdat... [open antwoord]

17. Welk vervoermiddel gebruikt $\mathrm{u}$ het minst voor deze reizen langer dan 20km? * [ 1 antwoord mogelijk] [Dropdown met selecties vraag 1] - optie wandelen

18. Wat is de reden dat $u$ dit vervoermiddel het minst gebruikt voor reizen langer dan $20 \mathrm{~km}$ ? * [meerdere antwoorden mogelijk]

- Moeilijk

- Niet beschikbaar

- Duur

- Ongezond

- Langzaam

- Slecht voor het milieu

- Ik kan niet samen reizen

- Anders, namelijk.....

19. Kunt $u$ aangeven welk vervoermiddel $u$ het meest gebruikt per reismotief voor reizen langer dan $20 \mathrm{~km}$ ? [1 optie per reismotief] dropdown

Als u een reismotief niet heeft, klik dan op Niet van toepassing.

- Van en naar werk

[dropdown vervoersmiddelen] nvt

- Zakelijk/ beroepsmatig

[dropdown vervoersmiddelen] nvt

- Onderwijs volgen

[dropdown vervoersmiddelen] nvt

- Diensten / Persoonlijk

[dropdown vervoersmiddelen] nvt

- Winkelen / Boodschappen doen

[dropdown vervoersmiddelen] nvt

- Halen / brengen kinderen

[dropdown vervoersmiddelen] nvt

- Sociaal / creatief

[dropdown vervoersmiddelen] nvt

- Wandelen / toeren

[dropdown vervoersmiddelen]

nvt

\section{Algemene vragen over uw huidig reisgedrag (tijdens Corona)}

20. Bent $u$ in het bezit van een auto?

- Ja, een leaseauto

- Ja, een eigen auto

- Ja, een leaseauto en eigen auto 
- Nee

21. Ik bezit een $\mathrm{OV}$-chipkaart

- Ja, een persoonlijke kaart met foto

- Ja, een anonieme kaart

- Nee

22. [Alleen voor antwoord 20: auto eigendom + auto lease] Hoeveel auto's zijn er in totaal in uw huishouden? *

- 1

- 2

- 3 of meer

23. [Alleen voor antwoord 20: auto eigendom + auto lease] In hoeverre bent $u$ het eens of oneens met de volgende stellingen? *

- Vanwege de coronacrisis maak ik meer gebruik van de auto in plaats van het openbaar vervoer (eens - oneens - geen mening)

- Ik gebruik de auto ook voor korte ritten die ik ook op de fiets, lopen en/of met de bus had kunnen doen (eens - oneens - geen mening)

- Ik wil minder gebruik maken van de auto (eens - oneens - geen mening)

- Ik wil meer gebruik maken van de (elektrische) fiets in plaats van de auto (eens - oneens - geen mening)

- Ik wil overstappen naar een elektrische auto (ervan uit gaande dat er voldoende laadpunten zijn) (eens - oneens - geen mening)

- Ik zou graag nog een auto kopen (eens - oneens - geen mening)

- Ik wil mijn auto verkopen en vaker reizen met een ander vervoermiddel (bv. fiets, OV, deelauto) (eens - oneens - geen mening)

24. Mijn dagelijkse activiteiten (studie/werk/vrijwilligerswerk) zijn vanuit huis te bereiken met de volgende vervoerwijzen: *

- De auto (eens - oneens - geen mening)

- De bus (eens - oneens - geen mening)

- De trein (eens - oneens - geen mening)

- De fiets (eens - oneens - geen mening)

- De elektrische fiets (eens - oneens - geen mening)

- Lopend (eens - oneens - geen mening)

25. In hoeverre bent $u$ het eens of oneens met de volgende stellingen? *

- Ik ben tevreden met het openbaar vervoer in mijn omgeving (eens - oneens - geen mening)

- Ik maak geen gebruik van het openbaar vervoer (eens - oneens - geen mening)

- Ik maak wekelijks gebruik van het openbaar vervoer (eens - oneens - geen mening)

- Ik maak maandelijks gebruik van het openbaar vervoer (eens - oneens - geen mening)

- Ik wil meer gebruik maken van openbaar vervoer (eens - oneens - geen mening)

- Ik zou graag meer gebruik maken van openbaar vervoer als er een groter aanbod is (bijvoorbeeld meer bushaltes, vaker een bus) (eens - oneens - geen mening)

- Ik zou graag meer gebruik maken van openbaar vervoer als het goedkoper wordt (eens - oneens - geen mening) 
- Ja, mijn mailadres is: [mailadres]

- $\quad$ Nee $\rightarrow$ vraag 7

Onder alle respondenten wordt $3 x$ een cadeaubon van $€ 50$ van Bol.com verloot. Als $u$ kans wilt maken, vul dan hieronder (nogmaals) uw mailadres in: [mailadres ]

\section{[Eindscherm vragenlijst]}

Hartelijk dank voor uw deelname aan deze enquête. Met het invullen draagt u bij aan mijn afstudeeronderzoek naar de kansen voor mobiliteit van de toekomst in het landelijk gebied in Nederland.

De antwoorden van respondenten worden alleen gebruikt voor dit onderzoek. Het onderzoek is goedgekeurd door de Universiteit Twente/ITC. Er zal zorgvuldig worden omgaan met alle gegevens en de privacywet zal worden nageleefd. Deelname aan dit onderzoek is anoniem en leidt niet tot een uniek persoon. De gegevens worden tijdens het onderzoek verwerkt en veilig bewaard en worden na afloop van het onderzoek verwijderd. Tijdens het onderzoek heeft alleen de onderzoeker toegang tot deze data. Voor vragen over dit onderzoek kun je contact opnemen met s.w.m.wierenga@student.utwente.nl (onderzoeker), m.j.g.brussel@utwente.nl (supervisor) of de Ethische Commissie van Universiteit Twente/TC ec-itc@utwente.nl 


\section{E. Filter, correction and coding rules}

Responses have been excluded in case of missing of relevant data, inclusion would produce too much errors:

\begin{tabular}{|l|l|l|}
\hline Issue & Decision & Comment \\
\hline Aborted survey & Exclusion & Exclusion \\
\hline Not complete \\
goalled-in with other or commercial & Exclusion & $\begin{array}{l}\text { Determined with comments in the } \\
\text { survey }\end{array}$ \\
\hline Response from outside study area & Exclusion & $\begin{array}{l}\text { Excluded postal codes }=<6900 \text { and } \\
>=7299 . \text { Also, a check has been } \\
\text { done within the postal codes when } \\
\text { numbers are flipped. For example } \\
7020 \text { does not belong to the study } \\
\text { area, but 7200 does. }\end{array}$ \\
\hline
\end{tabular}

Some results of the survey are included in the responses. Nevertheless there might be missing or conflicting information, requiring correction. Below the rules for correction are listed.

\begin{tabular}{|l|l|l|}
\hline Issue & Decision & \begin{tabular}{l} 
Comment \\
\hline $\begin{array}{l}\text { Education category does not fit } \\
\text { input }\end{array}$
\end{tabular} \\
\hline $\begin{array}{l}\text { Work category does not fit the } \\
\text { categories }\end{array}$ & $\begin{array}{l}\text { Correct } \\
\text { 'MBO' } \rightarrow \text { 'Middelbaaronderwijs } \\
(\mathrm{HAV}, \mathrm{WWO}, \mathrm{MBO})^{\prime}\end{array}$ \\
\hline
\end{tabular}




\section{F. Interview topic list}

From the research matrix a topic list is defined for the interviews with actors in the Achterhoek. This topic list is based on the research questions, expected/preferred information to be collected from each actor, literature review and output of the survey. Per actor, the topic list will serve as a guide in the interview. The exact question posed to each actor differs since there background, work or expertise differs.

Sustainable transportation

Example of questions:

- Welke uitdagingen zijn er voor jullie wat betreft de transitie naar duurzame mobiliteit?

- Hoe is dat voor de provincie? En voor de Achterhoek?

- Hoe ziet dat er in de praktijk uit voor ZOOV?

- Welke kansen zijn er voor jullie wat betreft de transitie naar duurzame mobiliteit?

- Hoe is dat voor de provincie? En voor de Achterhoek?

- Welke aspecten van duurzame mobiliteit zijn belangrijk voor uw organisatie?

- Hoe wordt duurzame mobiliteit vanuit uw organisatie nagestreefd?

- Wat verwacht u met duurzame mobiliteit te bereiken?

○ Op welke termijn?

o Hoe?

- Hoe ziet mobiliteit er over 10 jaar uit in de Achterhoek?

- $\quad$ Prov: "We stellen de reiziger meer centraal en verleiden de reiziger de slimste en schoonste keuzes te maken om door het netwerk te reizen." (Bereikbaar Gelderland in 2030)

- Hoe wordt dit in de Achterhoek opgezet?

- Hoe worden reizigers gemotiveerd/stimuleert om een andere keuze te maken? $\otimes$ Wat maakt het aantrekkelijk?

Modal choice / vervoerskeuze

Example questions:

- Wat beïnvloedt de keuze van reizigers om wel of niet van een bepaald vervoermiddel gebruik te maken?

- $\quad$ Autogebruik is dominant ten opzichte van andere vervoersmiddelen bij afstanden langer dan $5 \mathrm{~km}$. + Vanuit de enquête blijkt dat mensen tussen de 25 en 60 jaar naar verhouding veel gebruik maken van de vervuilende auto in de Achterhoek (t.o.v. OV).

- Hoe wordt deze groep reizigers gemotiveerd om gebruik te maken van (schoner) OV of fiets?

- Hoe zorgen jullie dat de autogebruiker voor kortere afstand ander (schoner) vervoer gebruikt?

- Hoe zorgen jullie dat reizigers gebruik gaan maken van duurzaam vervoer?

Accessibility / bereikbaarheid

- Hoe zorgen jullie dat er voor iedere doelgroep voldoende aanbod aan vervoer is?

- Hoe wordt de ov-bereikbaarheid van faciliteiten gegarandeerd in de Achterhoek?

- $\quad$ Provincie: "Daarbij zorgen we ook voor achterlandverbindingen en verbindingen met landelijke gebieden zoals de Achterhoek. Focus op stedelijke gebieden wil niet zeggen dat we ons voor $100 \%$ op deze gebieden richten. Ons uitgangspunt is dat iedere Gelderlander bereikbaar is en beschikt over de mogelijkheden om zijn/haar woon-, werk- en recreatiebehoeften in te vullen." (Bereikbaar Gelderland in 2030)

- Wat houden achterlandverbindingen in?

- Hoe worden deze opgezet?

- Minder focus op de Achterhoek, wat merkt de reiziger daarvan?

- Mobiliteitshubs zullen een belangrijke rol gaan spelen in de overgang naar duurzame mobiliteit. Hoe wordt dit in de Achterhoek opgezet?

o $\quad$ Op welke doelgroepen zijn deze mobiliteitshubs gericht? 
- Op welke doelgroep richt ZOOV zich?

\section{Stakeholders}

- Hoe gaat de samenwerking met de verschillende stakeholders in de Achterhoek (gemeenten, provincie, vervoerder, reizigersbelangen)? 


\section{G. MOTIVES PER TRANSPORT MODE AND DISTANCE}

Reason for most used

\begin{tabular}{|c|c|c|c|c|c|c|c|c|c|c|c|c|c|c|c|c|}
\hline $55^{0 / 0}$ & 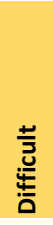 & $\begin{array}{l}\frac{0}{0} \\
\frac{\pi}{0} \\
\frac{10}{\pi} \\
\frac{1}{0} \\
\text { t0 } \\
2\end{array}$ & 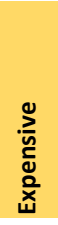 & 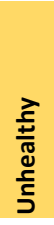 & 方 & 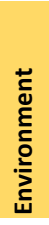 & 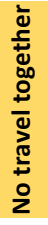 & $\stackrel{\mathscr{M}}{\uplus}$ & $55^{0 \%}$ & $\begin{array}{c}\text { ⿹े } \\
\text { జ }\end{array}$ & $\begin{array}{l}\frac{0}{8} \\
\frac{5}{U}\end{array}$ & 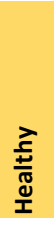 & 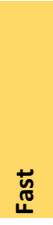 & 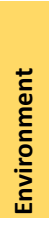 & 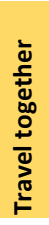 & $\stackrel{\Perp}{\Psi}$ \\
\hline Walking & 21 & 0 & 2 & 3 & 61 & 1 & 0 & 13 & Walking & 28 & 17 & 42 & 1 & 11 & 0 & 0 \\
\hline Bicycle & 8 & 8 & 8 & 0 & 27 & 0 & 8 & 42 & Bicycle & 23 & 19 & 28 & 12 & 17 & 1 & 0 \\
\hline E-bike & 19 & 0 & 0 & 0 & 31 & 0 & 6 & 44 & E-bike & 24 & 11 & 29 & 15 & 18 & 2 & 1 \\
\hline Speed pedelec & 0 & 0 & 0 & 0 & 0 & 0 & 0 & 0 & Speed pedelec & 25 & 13 & 25 & 38 & 0 & 0 & 0 \\
\hline Scooter/Moped & 0 & 0 & 17 & 0 & 17 & 50 & 0 & 17 & Scooter/Moped & 29 & 21 & 7 & 21 & 14 & 0 & 7 \\
\hline Car (owner) & 5 & 3 & 28 & 29 & 4 & 27 & 0 & 4 & Car (owner) & 52 & 1 & 0 & 32 & 0 & 3 & 13 \\
\hline Car (lease) & 5 & 5 & 29 & 24 & 5 & 24 & 0 & 10 & Car (lease) & 52 & 13 & 0 & 22 & 4 & 4 & 4 \\
\hline Shared car & 0 & 50 & 0 & 0 & 0 & 50 & 0 & 0 & Shared car & 0 & 0 & 0 & 0 & 0 & 0 & 0 \\
\hline Bus & 21 & 37 & 11 & 5 & 16 & 0 & 0 & 11 & Bus & 0 & 0 & 0 & 0 & 0 & 0 & 0 \\
\hline Train & 12 & 57 & 13 & 3 & 4 & 2 & 1 & 8 & Train & 0 & 0 & 0 & 0 & 0 & 0 & 0 \\
\hline Zoov & 0 & 17 & 17 & 17 & 0 & 0 & 17 & 33 & Zoov & 33 & 33 & 0 & 0 & 0 & 0 & 33 \\
\hline Other & 22 & 11 & 11 & 11 & 22 & 11 & 11 & 0 & Other & 33 & 0 & 0 & 0 & 0 & 0 & 67 \\
\hline
\end{tabular}

\begin{tabular}{|c|c|c|c|c|c|c|c|c|c|c|c|c|c|c|c|c|}
\hline $55^{5}$ & 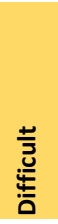 & $\begin{array}{l}\frac{0}{0} \\
\frac{0}{10} \\
\frac{10}{10} \\
\frac{1}{2} \\
\stackrel{0}{2}\end{array}$ & 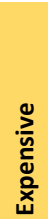 & 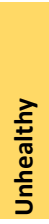 & $\frac{3}{n}$ & 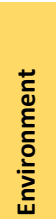 & 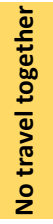 & $\stackrel{\Perp}{\Psi}$ & $5^{5^{4}}$ & స్ & $\begin{array}{l}\frac{0}{\pi} \\
\stackrel{d}{0}\end{array}$ & $\begin{array}{l}\text { ㄹ } \\
\frac{ \pm}{\pi 刃} \\
\frac{d}{x}\end{array}$ & 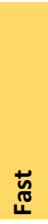 & 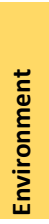 & 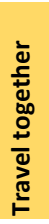 & $\stackrel{\Perp}{\Psi}$ \\
\hline Bicycle & 19 & 1 & 2 & 2 & 56 & 0 & 6 & 14 & Bicycle & 19 & 20 & 28 & 9 & 22 & 1 & 1 \\
\hline E-bike & 26 & 5 & 0 & 3 & 46 & 2 & 8 & 11 & E-bike & 24 & 17 & 28 & 11 & 15 & 2 & 1 \\
\hline Scooter/Moped & 0 & 50 & 0 & 25 & 25 & 0 & 0 & 0 & Speed pedelec & 0 & 33 & 33 & 0 & 33 & 0 & 0 \\
\hline Car (owner) & 5 & 4 & 29 & 27 & 1 & 30 & 0 & 5 & Scooter/Moped & 27 & 20 & 0 & 33 & 0 & 0 & 20 \\
\hline Car (lease) & 13 & 13 & 25 & 25 & 0 & 25 & 0 & 0 & Car (owner) & 46 & 3 & 1 & 42 & 0 & 6 & 3 \\
\hline Shared car & 0 & 0 & 0 & 0 & 0 & 0 & 0 & 100 & Car (lease) & 43 & 12 & 0 & 36 & 5 & 5 & 0 \\
\hline Bus & 19 & 19 & 15 & 4 & 19 & 0 & 4 & 19 & Shared car & 33 & 33 & 0 & 33 & 0 & 0 & 0 \\
\hline Train & 19 & 49 & 20 & 2 & 6 & 1 & 0 & 2 & Bus & 47 & 18 & 0 & 24 & 12 & 0 & 0 \\
\hline Zoov & 0 & 0 & 25 & 25 & 25 & 0 & 0 & 25 & Train & 38 & 10 & 3 & 17 & 24 & 3 & 3 \\
\hline \multirow[t]{2}{*}{ Other } & 17 & 0 & 17 & 0 & 50 & 0 & 17 & 0 & Zoov & 25 & 25 & 0 & 25 & 0 & 0 & 25 \\
\hline & & & & & & & & & Other & 0 & 0 & 0 & 0 & 0 & 0 & 100 \\
\hline
\end{tabular}

\begin{tabular}{|c|c|c|c|c|c|c|c|c|c|c|c|c|c|c|c|c|}
\hline $2^{05^{0.0}}$ & 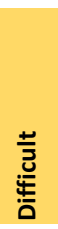 & 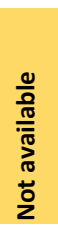 & 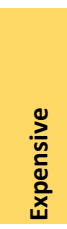 & 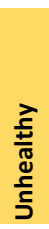 & $\frac{3}{n}$ & 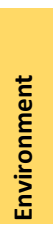 & 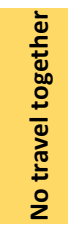 & $\stackrel{\mathscr{\omega}}{\Psi}$ & $2^{05^{2 / 0}}$ & సે & $\begin{array}{l}\frac{0}{\pi} \\
\stackrel{d}{0}\end{array}$ & $\begin{array}{l}\underset{T}{ \pm} \\
\frac{ \pm}{\pi} \\
\stackrel{0}{I}\end{array}$ & 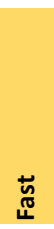 & 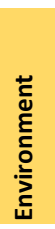 & 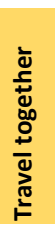 & $\stackrel{\dddot{\varkappa}}{\Psi}$ \\
\hline Bicycle & 28 & 1 & 1 & 2 & 55 & 0 & 4 & 9 & Bicycle & 9 & 27 & 36 & 9 & 18 & 0 & 0 \\
\hline E-bike & 35 & 1 & 2 & 2 & 51 & 0 & 3 & 6 & E-bike & 26 & 20 & 26 & 11 & 17 & 0 & 0 \\
\hline Speed pedelec & 0 & 0 & 0 & 0 & 0 & 0 & 100 & 0 & Speed pedelec & 0 & 0 & 0 & 50 & 50 & 0 & 0 \\
\hline Scooter/Moped & 0 & 0 & 0 & 0 & 100 & 0 & 0 & 0 & Scooter/Moped & 38 & 13 & 13 & 38 & 0 & 0 & 0 \\
\hline Car (owner) & 15 & 4 & 38 & 8 & 4 & 12 & 0 & 19 & Car (owner) & 42 & 3 & 1 & 41 & 0 & 9 & 4 \\
\hline Car (lease) & 0 & 0 & 0 & 0 & 0 & 0 & 0 & 100 & Car (lease) & 41 & 18 & 0 & 35 & 2 & 4 & 0 \\
\hline Shared car & 0 & 0 & 100 & 0 & 0 & 0 & 0 & 0 & Shared car & 40 & 0 & 0 & 60 & 0 & 0 & 0 \\
\hline Bus & 31 & 31 & 0 & 8 & 23 & 0 & 0 & 8 & Bus & 50 & 0 & 0 & 25 & 25 & 0 & 0 \\
\hline Train & 29 & 38 & 18 & 3 & 9 & 0 & 0 & 3 & Train & 34 & 11 & 1 & 27 & 16 & 6 & 5 \\
\hline Zoov & 25 & 25 & 25 & 25 & 0 & 0 & 0 & 0 & Zoov & 20 & 20 & 0 & 40 & 0 & 0 & 20 \\
\hline Other & 20 & 40 & 20 & 0 & 20 & 0 & 0 & 0 & Other & 33 & 0 & 0 & 33 & 0 & 0 & 33 \\
\hline
\end{tabular}




\section{H. CODE REPORT}

30's

1 Groups:

Organisation

13 Quotations:

1:11 $\mathbb{2} 2$ in Transcript $D$

Achterhoek die die hebben wij een coöperatief weggezet, oftewel wij hebben contact gehouden met energiecoöperaties in de Achterhoek die zelf energie opwekken voor hun omgeving, die eventueel interesse zouden hebben in deelauto's, een elektrische deelauto, die hadden ze, die kern hebben we gevonden in Groenlo en Zieuwent, en die willen dat ook ja, die wilde ook heel graag dan auto's op locatie, verschillende locaties binnen de kernen dan neerzetten, het mooiste is dat je dan die combinatie kan maken. Zij wekken die energie al op, zij kunnen daar een laadpaal neerzetten en energie komt dan ook echt uit de Achterhoek. Dus die auto's die rijden echt op lokale opgewekte stroom, ja dus, dat is ideale combinatie, dus proberen we ook steeds meer uitrollen

1:17 शा 6 in Transcript D

Ook hebben we een hoop mobiliteitmakelaars in de Achterhoek lopen die ook bij bedrijven langsgaan om hen te helpen met het energievraagstuk en met de duurzaamheidsvraagstukken van kunnen jullie binnen je bedrijf misschien wel verbeteren

\section{1:26 \ 15 in Transcript D}

Die is er zo op ingericht dat die heeft een drie O-structuur. En dan moet je denken dat wij in samenwerking met de overheid - dat is altijd standaard - ondernemers, maatschappelijke organisaties, en wij binnen die overheid zijn niet enkel de gemeente, maar de provincie die ze is er ook standaard bij betrokken. Dus die die zit ook in alle overleggen, je hebt een een Achterhoekraad.

\section{1:27 T 19 in Transcript D}

Ook in de Achterhoek zit nou ja, de leden in de Achterhoek die hebben dus een gewogen stem

\section{1:29 \ा 19 in Transcript D}

Maar daaronder heb je de Achterhoek Board en die Achterhoek Board bestaat ook uit die drie O-structuur: de overheid, ondernemers, maatschappelijke organisaties, maar er zit ook standaard de gedeputeerde van de provincie Gelderland bij op die manier.

\section{1:31 I 19 in Transcript D}

Op deze manier die drie $\mathrm{O}$ structuur - met al die partijen die aan de voorkant zitten - zorgen ervoor dat je beter beleid kunt maken en dat je verschillende perspectieven goed kunt combineren

\section{1:37 \ा 25 in Transcript D}

Vooral ook omdat wij coöperatief willen werken. Bottom up kijken wat er ligt in de samenleving, ook met projecten, en om die link te maken.

\section{3:4 II 12 in Transcript B}

amenwerking is, is triple georganiseerd, dus overheden met het bedrijfsleven samen en maatschappelijke organisaties en één van de zes thema's. Mobiliteit, dus dat zit daar goed in verankerd, is een thema tafel waar die ontwikkelingen ook worden gesignaleerd en waar dat moet leiden tot het starten, het brengen van projecten.

\section{3:25 \ा 72 in Transcript B}

ik vind die drie $O$ samenwerking rondom het thema mobiliteit niet zo ver ontwikkeld. Eerlijk gezegd is het nog een aardig beleid gedomineerde thema tafel. De ambtenaren hebben daar nog wel een grote invloed, zeg maar en de bestuurders dus. De betrokkenheid van ondernemers is eigenlijk nog veel te weinig. Maar het zoeken naar een vorm van mobiliteitscoöporatie of coöperatieve structuur, dat vind ik dan wel echt vernieuwend en dat is ook wel vernieuwend vergeleken met de rest van het land. Maar goed, het is een idee op papier dus eerst maar eens zien dan we geloven. Dus laten we eens kijken of we hebben dat ze gewoon te krijgen. Ik denk dat het nog wel echt de grootste slag is die geslagen moet worden. Dat is dat je ook wel mobiliteitsvragen van het bedrijfsleven, moet betrekken, misschien als opdrachtgever. Ja, heel praktisch lijn 82 is gaat naar Doetinchem langs Steenderen. Die maakt een lus om Steenderen heen. Precies langs bepaalde bedrijven. Dan is het belangrijk dat je als locatie goed bereikbaar bent. Maar dat is niet met een gestrekte buslijn. Dus als je goede opstappunten creert, met een vorm 78 
1 Groups:

Organisation

13 Quotations:

\section{1:11 $₫ 2$ in Transcript D}

Achterhoek die die hebben wij een coöperatief weggezet, oftewel wij hebben contact gehouden met energiecoöperaties in de Achterhoek die zelf energie opwekken voor hun omgeving, die eventueel interesse zouden hebben in deelauto's, een elektrische deelauto, die hadden ze, die kern hebben we gevonden in Groenlo en Zieuwent, en die willen dat ook ja, die wilde ook heel graag dan auto's op locatie, verschillende locaties binnen de kernen dan neerzetten, het mooiste is dat je dan die combinatie kan maken. Zij wekken die energie al op, zij kunnen daar een laadpaal neerzetten en energie komt dan ook echt uit de Achterhoek. Dus die auto's die rijden echt op lokale opgewekte stroom, ja dus, dat is ideale combinatie, dus proberen we ook steeds meer uitrollen

1:17 96 in Transcript D

Ook hebben we een hoop mobiliteitmakelaars in de Achterhoek lopen die ook bij bedrijven langsgaan om hen te helpen met het energievraagstuk en met de duurzaamheidsvraagstukken van kunnen jullie binnen je bedrijf misschien wel verbeteren

\section{1:26 \} 1 5 \text { in Transcript D }}

Die is er zo op ingericht dat die heeft een drie O-structuur. En dan moet je denken dat wij in samenwerking met de overheid - dat is altijd standaard - ondernemers, maatschappelijke organisaties, en wij binnen die overheid zijn niet enkel de gemeente, maar de provincie die ze is er ook standaard bij betrokken. Dus die die zit ook in alle overleggen, je hebt een een Achterhoekraad.

\section{1:27 II 19 in Transcript D}

Ook in de Achterhoek zit nou ja, de leden in de Achterhoek die hebben dus een gewogen stem

\section{1:29 \ा 19 in Transcript D}

Maar daaronder heb je de Achterhoek Board en die Achterhoek Board bestaat ook uit die drie O-structuur: de overheid, ondernemers, maatschappelijke organisaties, maar er zit ook standaard de gedeputeerde van de provincie Gelderland bij op die manier.

\section{1:31 I 19 in Transcript $D$}

Op deze manier die drie $O$ structuur - met al die partijen die aan de voorkant zitten - zorgen ervoor dat je beter beleid kunt maken en dat je verschillende perspectieven goed kunt combineren

\section{1:37 \ा 25 in Transcript D}

Vooral ook omdat wij coöperatief willen werken. Bottom up kijken wat er ligt in de samenleving, ook met projecten, en om die link te maken.

\section{3:4 II 12 in Transcript B}

amenwerking is, is triple georganiseerd, dus overheden met het bedrijfsleven samen en maatschappelijke organisaties en één van de zes thema's. Mobiliteit, dus dat zit daar goed in verankerd, is een thema tafel waar die ontwikkelingen ook worden gesignaleerd en waar dat moet leiden tot het starten, het brengen van projecten.

\section{3:25 972 in Transcript B}

ik vind die drie $O$ samenwerking rondom het thema mobiliteit niet zo ver ontwikkeld. Eerlijk gezegd is het nog een aardig beleid gedomineerde thema tafel. De ambtenaren hebben daar nog wel een grote invloed, zeg maar en de bestuurders dus. De betrokkenheid van ondernemers is eigenlijk nog veel te weinig. Maar het zoeken naar een vorm van mobiliteitscoöporatie of coöperatieve structuur, dat vind ik dan wel echt vernieuwend en dat is ook wel vernieuwend vergeleken met de rest van het land. Maar goed, het is een idee op papier dus eerst maar eens zien dan we geloven. Dus laten we eens kijken of we hebben dat ze gewoon te krijgen. Ik denk dat het nog wel echt de grootste slag is die geslagen moet worden. Dat is dat je ook wel mobiliteitsvragen van het bedrijfsleven, moet betrekken, misschien als opdrachtgever. Ja, heel praktisch lijn 82 is gaat naar Doetinchem langs Steenderen. Die maakt een lus om Steenderen heen. Precies langs bepaalde bedrijven. Dan is het belangrijk dat je als locatie goed bereikbaar bent. Maar dat is niet met een gestrekte buslijn. Dus als je goede opstappunten creert, met een vorm van collectief vervoer. Dat zou ik interessant vinden, daarmee kijk je wat goed aansluit bij wat dan daadwerkelijk de behoefte is voor die werknemer, van die werkgever. 


\section{4:6 \ा 20 in Transcript A}

wij geloven er niet in dat je van bovenaf kan bepalen waar je wat neerzet. Dit is in steden natuurlijk met heel anders met aanbieders. Ja, die zet er ergens wat neer, omdat ze denken vanuit allerlei analyse met data dat daar vraag is. Even cru, maar dat is een beetje hoe het gebeurd. In de achterhoek gaan we het anders aanpakken. Wij geloven heel erg van de kracht van onderop, dus dat wil zeggen dat wij echt wachten en natuurlijk stimuleren. Dat hè, maar ik zeg dan maar eventjes wachten totdat van onderop de vraag komt: hè, wij willen iets met een deelauto deelfiets $\mathrm{mmm}$ dus toen die challenge werd neergezet door meneer Bouwmans was dat heel mooi. Toen waren we ondertussen al een beetje bezig met de deelfiets. Dus dat scheelt met de toeristische sector, alleen, wat merk je dan? Kijk een aanbieder van fietsen, Urbee in dit geval of arriva die als partner meedoet, dat die hebben een hele andere filosofie, visie, denkwijze, de andere business dan dat je aan de vraagkant, dus waar we op zaten, te wachten. Aan de vraagkant zal bijvoorbeeld toeristische sector zeggen: ja, we willen gewoon fietsen kunnen verhuren. Arriva zegt wij willen onze bus goed kunnen vullen en u zegt: ik wil mijn fietsen zoveel mogelijk kunnen inzetten. Dus waar zit de grootste uitdaging? De verschillende businessmodellen? Misschien kun je dat soort best omschrijven van de partijen en je bij elkaar proberen te brengen om dat op één lijn te krijgen. Dan zeggen uitdaging. Het makkelijkste was Urbee bellen.

\section{4:7 श 29 in Transcript A}

De overheid kunnen niet zelf fietsen gaan exploiteren, want dan gaan we natuurlijk volledig langs alle regels in die we landelijk hebben gesteld, maar wachten tot een aanbieder zich aanbiedt zoals Urbee. Ja, dat heeft ook geen zin. Kijk, je krijgt ook echt wel wat geld voor het feit dat die fietsen staan. We hebben je doet ook mee, dus we hebben ook gezegd van ja, we gaan niet die fietsen volledig betalen. Jij moet ook zelf risicodragend meedoen, maar de toeristische sector risico dragen bij.

\section{4:8 श 31 in Transcript A}

We hebben nu bijvoorbeeld de eerste elektrische deelauto's die in Groenlo komt te staan, drie elektrische deelauto's. Daar hebben wij de energiecoöperatie Groenlo die doet mee. Dus die is, zeg maar even de vragende partij geweest, dus die betalen die auto's. We hebben de leverancier van de auto, dat is een dealer die gewoon de auto levert, die doet hè, die doet ook risico mee voor een stukje. We hebben natuurlijk de eerste klanten die zich hadden aangemeld die door risicodragend mee de launching customers, zoals we die zo mooi noemen. Ja en de rest financieren wij vanuit de overheid, alleen hoe doen we dat dan? Nou, dat gaan we dus doen via de coöperatie. Dus wat we aan het doen zijn is een hele coöperatie opzetten: overheid, ondernemers, energiecoöperaties, maatschappelijke instellingen, dus bijvoorbeeld de ziekenhuizen, de hogeschool of de ROC. Die kunnen allen participeren in die coöperatie, en daarmee hebben we dat dus ontwikkeld. We hebben het dus met elkaar. Ook de kosten kunnen delen, waardoor we dus ook een bestendig duurzaam model kunnen neerzetten. Want als we hadden gezegd van nou, weet u, we doen alleen maar wat geld voor die auto in Groenlo dat we één ding zeker de kans dat die auto's over vier jaar als de subsidie afgelopen is en dan nog rijden. Nou, dat is daar bijna een gelukje. Zou bijna zeggen doordat we er in de coöperatie mee bezig zijn, kunnen we ook gewoon na die vier jaar prima nog wat geld eventueel daarvoor besteden als dat nodig is, omdat we ook weten dat het daarmee iets in stand te houden. Maar dat betekent ook dat er aan de andere kant geld van andere partijen wel bij moet. lk bedoel: wij gaan als overheid niet ondernemen, maar dat kan best wel zijn dat deze actie in Groenlo dadelijk wel geld oplevert. Die auto's. Dus daar is geen geld bij nodig, maar daar wordt geld verdiend, maar dat misschien in een ander dorp de auto wel nog wat geld nodig heeft. Maar dat is waar we dat coöperatief doen, omdat je dan met elkaar de lusten en lasten deelt. 5:11 939 in Transcript $F$

We hebben wel vaker geprobeerd hè om mobiliteit aanpakken. In regio's projecten op te pakken, hè, met mobiliteitsmakelaars en zo, dat is ook niet een heel nieuw woord. In het verleden hadden wij dan vaak geld en dan gingen we aan de slag. En als het geld op was, dan zakte dat weer in mekaar en er liggen nu kansen om dat eh in de samenwerking met de Achterhoek, om dat niet te laten gebeuren. Dus om ook iets blijvends te maken. Er ligt ook nu een kans in de Achterhoek om dat met alle regionale partners te doen, dus niet alleen met de gemeente, hè, maar ook met ondernemers, met organisaties als het nieuwe slingeland ziekenhuis en dat soort zaken, hè. De Achterhoek is nu georganiseerd op die drie hè, overheid, ondernemers en organisaties, en die werken daar ook steeds meer samen in samen. En volgens mij is dat ja de grote kans die er nu ligt in de Achterhoek om het nu echt iets blijvends te maken. Een stap verder te brengen, want als je het trekt puur vanuit de overheid, dan blijft het vaak 80 
een beetje in die voorbeeldprojecten en die pilot hangen.

Q 8RHK

1 Groups:

Organisation

6 Quotations:

\section{1:26 \ 15 in Transcript D}

Die is er zo op ingericht dat die heeft een drie O-structuur. En dan moet je denken dat wij in samenwerking met de overheid - dat is altijd standaard - ondernemers, maatschappelijke organisaties, en wij binnen die overheid zijn niet enkel de gemeente, maar de provincie die ze is er ook standaard bij betrokken. Dus die die zit ook in alle overleggen, je hebt een een Achterhoekraad.

\section{1:28 \ा 19 in Transcript $D$}

ou, de Achterhoekraad die is opgesteld om ervoor te zorgen dat de grote lijnen die visie wordt vormgegeven, de monitoring op grote, op grote schaal goed wordt, wordt gedaan, eventueel een nieuwe aanvullingen op die visie of nieuwe projecten. Nieuwe kansen die er, liggen te initiëren. Dat is de Achterhoek, en die vergaderd dan ook vier keer per jaar tenminste

\section{1:30 \ा 19 in Transcript D}

De gedachte erachter is dat voor één had je gemeentes uit je provincie, maar die maken beleid en die schrijven het heel mooi uit en is ook heel veel, is heel goed over nagedacht. Het moment dat je dat gaat uitrollen. Ja, en dan komt het in de samenleving terecht. En dan zie je, daar heb je beleid en dan heb je ondernemers die het beleid kijken

\section{1:32 119 in Transcript D}

Daarachter zit een Board die die monitort en die bewaakt. De Achterhoek visie die is opgesteld door de Achterhoek raad, en die zorgt er ook voor dat projectaanvragen, worden gekeurd, als het ware worden gecheckt op de eisen die we hebben gesteld, die we hebben vastgesteld en of ze voldoen aan die achterhoek visie

\section{1:34 \ा 21 in Transcript D}

Maar de visie van Gelderland past goed bij onze visie die wij hebben vastgesteld. Dus ja, het is, het is heel gemakkelijk deze manier van samenwerken en het is ook, mede dankzij het feit dat zij gewoon zijn aangesloten bij de regio vergaderingen. Dus. Het is voor mijn tijd, maar ik, ik zie dat nou dat het uitvoeren dat dat goed is en die samenwerking gewoon fijn is.

\section{6:9 \ 49 in Transcript $E$}

In de achterhoek hebben we een vrij stevig idee wat wij zouden willen. Daar werken we samen als overheden met de vervoerders, maar ook met andere bedrijven binnen de achterhoek ambassadeurs. Nee, dat gaat wel goed, want daar zitten we ook. We proberen ook al die eindjes aan elkaar te knopen. Ook het mobiliteitsportaal is bijna klaar voor de achterhoek. We hebben netmobiel. Wij zijn het gesprek aan het voeren met arriva, maar dat zit allemaal aan elkaar, want de arriva zit ook weer in Netmobiele. We zijn ook wel een handjevol mensen, dus die weten precies van elkaar en zijn op de hoogte dan gaat denk ik wel goed. Ehm voor de Rijksoverheid die is volgens mij niet zo geïnteresseerd wat wij hier aan het doen zijn ehm. Ze hebben natuurlijk MaaS pilots. Ja, wij zijn waarschijnlijk de eerste die het klaar hebben. Daar kunnen we van profiteren, in die zin dat bijvoorbeeld arriva de laatste Maas pilot in Groningen Drenthe heeft gewonnen, die ook gaat over Wmo vervoer. Dus ja, wat zij daar ontwikkelen kan hier gelijk toegepast worden.

Q Bottom Up

1 Groups:

Organisation

5 Quotations:

\section{1:12 If 4 in Transcript D}

En dan geloven in de kracht van de cooperaties van bottom bottom up in plaats van top to bottom, want in in in onze optiek werkt dat niet in een ruraal gebied

\section{1:31 \} 1 9 \text { in Transcript D }}

Op deze manier die drie $\mathrm{O}$ structuur - met al die partijen die aan de voorkant zitten - zorgen ervoor dat je beter beleid kunt maken en dat je verschillende perspectieven goed kunt combineren 
Wij hebben het Achterhoek panel in de Achterhoek en dit Achterhoek panel, is bij de start van onze vernieuwde samenwerking gebruikt. We hebben de Achterhoekers ondervraagd. Welke thema's voor 2030 zijn de belangrijkste thema's voor hen? Nou, dr. Zijn enkele uitkomsten uitgekomen en die zijn ook verwerkt in de Achterhoek visie en tegelijkertijd worden die ook gebruikt, die resultaten van de Achterhoek panel, bij de toetsing van onze projectenaanvragen, en op die manier hebben we - dat vinden wij in ieder geval - de bewoners ondervangen 1:38 \ा 27 in Transcript D

Nee, wij willen echt dat die gebruikt gaat worden. Dus wij hadden vooraf ook echt als eis gesteld. Wij willen wel aan de voorzijde, dat jullie net als wij risico delend inzitten, dus ervoor te zorgen dat de krachten gebundeld zijn. Je zet risico delend in. Oké, jullie moeten aan de voorkant zoveel abonnementen of prepaid, goede ET cetera, verkopen om dan quitte te draaien. Nou, dat is volgens ons heel goed model, krachtig inzetten, maar we willen wel die stok achter de deur hebben dat die ook blijft.

\section{2:24 \ा 14 in Transcript C}

Je kunt die consequenties voor jezelf goed inschatten, maar hoe de reiziger dat gaat pikken dat is veel moeilijker in te schatten en dat komt voor een groot deel volgens mij, omdat dat niet echt is aangegeven wat de reiziger precies moet, en daar zit je ook wel weer met het dilemma. Dat is een beetje flauw, want wat ik aanhaal dat heb je ongetwijfeld allemaal vaker gehoord. Je moet niks aan de klanten vragen. Je moet het gewoon doen en dat je dan terug hoort: dat is wat ik wilde. Maar dat krijg je niet te horen als je zegt: wat wil je? Wat willen jullie? Ook klanten denken vaak aan dat wat ze kennen. Dan zeg je eigenlijk wil ik liever dat die bus vier keer per uur gaat, maar wat ze eigenlijk willen is dat ze kunnen reizen als zij willen en vier keer per uur maakt dat min of meer wanneer ze willen. Maar dat spreken ze niet zo uit. Dus het is heel lastig om klanten daar op een goede manier bij te betrekken, denk ik, en dan de goede antwoorden te krijgen of de informatie die je kunt gebruiken ehm doordat gebrek een bepaald referentiekader.

$\otimes$ Bureaucratic

1 Groups:

Organisation

5 Quotations:

1:30 \} 1 9 \text { in Transcript D }

De gedachte erachter is dat voor één had je gemeentes uit je provincie, maar die maken beleid en die schrijven het heel mooi uit en is ook heel veel, is heel goed over nagedacht. Het moment dat je dat gaat uitrollen. Ja, en dan komt het in de samenleving terecht. En dan zie je, daar heb je beleid en dan heb je ondernemers die het beleid kijken 2:21 II 10 in Transcript C

Want als er een visie wordt ontwikkeld dan dat moment kun je natuurlijk niks doen, want je, je bent nog bezig met de visie. Dus het eerste wat men doet zodra die klaar is meteen beginnen met een nieuwe voor mij. Dit is wat kritisch, maar dat is echt mijn visie op wat één van de probleem is om steeds verder te komen dat men te veel blijft hangen in het praten over en discussiëren over en het toekomstbeelden, samenstellen, visie, enzovoort, enzovoort. Op een gegeven moment moet je gewoon een keer aan de slag en dan komt die weerstand. En dan komt dus ook ja, de koudwatervrees zeg maar ja en dan het stokt het ja. En dan sta je eigenlijk weer terug bij af, zeg maar. Dat is de grootste uitdaging voor duurzaam: is ook lef van alle partijen. Ook vervoerders natuurlijk hè, want zeker als je als je de eerste bent of zo ja, je kunt ook vreselijk op je bek gaan.

2:23 \ 14 in Transcript C

Maar ik heb het idee dat in Nederland er, vooral door kennis dragers mensen zoals jij in en ik, anders wordt geanalyseerd, gekeken naar cijfers, naar ontwikkelingen, naar trends in andere business dan die van ons.

2:41 If 44 in Transcript C

Daar moet je doorheen breken, maar als je in een traditioneel beroepsgroep zit, zeg maar of over business, zoals het openbaar vervoer. Ja, dan is het heel moeilijk om met dat soort mechanisme te kunnen en mogen werken, zeg maar.

\section{3:9 \ 30 in Transcript B}

Volgens mij wordt gewoon gekeken naar het benutten van technologische mogelijkheden en een nieuwe innovaties, en dat dat beter zou zijn, of dat wat we nu hebben anders in stand zou kunnen blijven. Daar hoor ik niemand over, dus of dat heel expliciet überhaupt een rol speelt, dat weet ik eerlijk gezegd niet.

82 
$\otimes$ Car dependent

2 Groups:

Behaviour / Mobility

5 Quotations:

1:4 $\mathbb{2} 2$ in Transcript D

, is dat mensen echt afhankelijk zijn van hun eigen aut

1:5 I 2 in Transcript D

De Achterhoekers zijn echte autorijders en om dat zo duurzaam mogelijk te maken...

\section{2:29 \ा 22 in Transcript C}

Ik denk alleen dat men dreigt snel uit het oog te verliezen, wellicht is dat mensen uiteindelijk altijd maar behoefte hebben aan een vorm van mobiliteit. Het is leuk dat er haltes zijn en fietsen en bussen en treinen, maar ik maak gebruik van alle zeg maar dus voor de reiziger blijft het gewoon een overstap van mobiliteitsvorm naar de andere mobiliteit voor. En ik heb soms een beetje het idee in deze discussies nogmaals die nog verder uitgewerkt moeten gaan worden. Dat beeld gaat zich ontwikkelen de komende jaren dat men, als er maar veel is, veel fietsen staan en scooters en acties en bussen en deelfietsen, dan denken mensen, daar moet ik naar toe. Terwijl ik denk van ja, mensen denken van ja, ik moet daar gewoon weer overstappen, dus het is niet zo dat als je maar veel hubs neerzet dat mensen dan denken: "nu ga ik gebruik maken van het openbaar vervoer", want liefst hebben ze natuurlijk gewoon een auto voor de deur.

\section{2:34 II 30 in Transcript C}

de verstokte automobilist? Daar moet je geen geld aan besteden in de vorm van campagnes, want dat is gewoon weggegooid geld. De argumenten die je over het algemeen aanhalen waarom ze geen gebruik van het openbaar vervoer zijn niet vaak niet de echte argumenten, want als je het argument wegneemt dan komt er vervolgens wel een ander argument. Het zijn gewoon voor de hand liggende smoesjes, en men gaat daar gewoon niet op overstappen, tenzij het op een gegeven moment wordt gedwongen, hè, dus de binnenstad wordt afgesloten voor autoverkeer. Of zo ja, dan wordt het een ander verhaal. lk denk ook dat het meest krachten heeft inderdaad om mensen te overtuigen dat het dat het gewoon een prima manier is om te reizen.

\section{2:45 \ा 52 in Transcript C}

ik denk dat je dan mogelijk ook het moment bereikt waarop mensen MaaS-mobiliteit inderdaad hebben ontdekt. Arriva is een partij die investeert, maar dat zijn heel veel partijen die daarin investeren, ook allemaal met een business case eronder. Als ik heel eerlijk ben, denk ik dat veel mensen daarin nog wel teleurgesteld gaan raken, de eerste jaren in relatie tot de verwachte opbrengsten, omdat je volgens mij toch altijd te positief wordt gedacht. Over die gedrag is aanpassingen. Mensen zitten vast in bepaalde gedragingen. Die zijn er echt niet zomaar uit te krijgen, ook al heb je goede tools en goede middelen, en het OV zelf is daarvan een prima voorbeeld. Dat hebben het net ook al besproken, want ze gaan echt niet zomaar van af. Ik denk dat daar de verwachtingen wel wat overspannen zijn, maar dat je dus inderdaad over 10-15 jaar.lk denk nee, maar over tien 15 jaar kan ik me voorstellen dat mensen wel bereid zijn om die gedrag aanpassing op zichzelf toe te gaan passen en dat men dat gaat ontdekken. En ik geloof ik echt in een sneeuwbaleffect. Niemand doet het, dus ik doe het ook niet totdat je in je omgeving op een gegeven moment mensen ziet die dat doen en die je meenemen samen. Kijk je dit aan, oké, oh, dat is eigenlijk zo makkelijk. Nou, en op een gegeven moment, dan ben je om, want die omgeving heb je voldoende mensen die doen. Dus je hebt bepaalde voorbeeldfunctie is. En dan pak je dat op en ik denk dat we over tien 15 jaar wel ongeveer zo ver zijn dat mensen Maas.

$\otimes$ Challenges

1 Groups:

Development

49 Quotations:

\section{1:4 92 in Transcript D}

, is dat mensen echt afhankelijk zijn van hun eigen aut

1:13 94 in Transcript D

Dan zie je bedrijven die op een gat inspringen. Ja, ik weet niet hoeveel auto's en fietsen op gooien en waar ook automatisch gebruik van wordt gemaakt, omdat dat gewoon een hele dichte locaties, dichtbevolkte locaties zijn. 
Ja, dan dan heb je heel veel vraag naar bepaald vervoer. Vervoersmiddelen in de Achterhoek is dat niet, zoals ik al zei, vanwege het uitgestrekt gebied, dunne lijnen en grote afstanden. Ja, dat maakt het lastig

1:15 $\mathbb{} 6$ in Transcript $D$

heel veel bewegingen worden gemaakt die misschien niet nodig zijn

$1: 18$ \ 8 in Transcript D

is dat er heel veel auto's zijn

1:19 98 in Transcript $D$

Dat is eigenlijk gewoon doodnormaal. Die staan 23 uur van de dag stil. Nemen ook heel veel ruimte in beslag en zijn eigenlijk niet nodig.

1:23 $\mathbb{1} 11$ in Transcript D

Netmobiel die verzorgt straks een app waarin ook is verwerkt waarin ook deelvoertuigen op dit moment modaliteiten zijn verwerkt, OV is verwerkt en dergelijke om alles te koppelen met betrekking op Maas, en OV binnen de Achterhoek. Dus dat zou echt onze eigen app worden, waarmee al die duurzame vormen van mobiliteit worden verenigd, maar ook het rit delen. En wij verwachten ook dat daar binnen de Achterhoek heel veel kansen liggen.

1:36 \ 23 in Transcript D

Neemt niet weg dat wij continu onze voelsprieten uitzetten, omdat wij die drie $\mathrm{O}$ structuren hebben omdat we zoveel verschillende mensen aan tafel hebben van verschillende organisaties, ondernemingen, overheden, gemeentes, provincie, ET cetera.

1:40 \ा 37 in Transcript D

Je kunt je auto's niet parkeren en je bent misschien slecht ter been. Ja, je hebt geen, je hebt geen alternatief op dat moment, want het is nog niet op zo'n grote schaal uitgevoerd. Die deal is dat mensen die deel auto ook echt kunnen laten staan

\section{1:43 शा 47 in Transcript D}

En daarbij willen we die die hoofdlijnen die die de nou liggen - ik had het in het begin al gezegd - die zijn heel dun ehm. Die willen we in ieder geval goed te houden. Maar willen we wel voor zorgen dat ze 's avonds en dan merk je s avonds, wordt er heel weinig gebruikgemaakt van het OV en met name de bus dan dat die niet onnodig moeten gaan rijden. Dat is gewoon zonde en geld weggooien, en dat vindt ook arriva.

\section{2:2 $\ 2$ in Transcript C}

Dat is voor bussen niet anders. Alleen gaat daar nog veel meer geld in om en je beperkt je daarmee ook heel erg op twee manieren: je moet rijden, daar waar je kunt, maar je lijnnetwerk leg je heel erg vast en je snapt dat als je ergens investeert in een laadpunt op

\section{2:3 \ा 2 in Transcript $C$}

Dat batterijbussen een beperkte actieradius hebben in vergelijking met dieselbussen, en dat die ook voortdurend dus aan de stekker moeten, zeg maar om het volgende stuk te kunnen rijden

\section{2:5 \ा 6 in Transcript C}

os daarvan zei ik al: die bussen moeten aan de stekker als je aan de stekker moet. Dat betekent dat je stilstaat en gaat laden. Dat kost nog wel wat tijd ehm

\section{2:7 96 in Transcript C}

Nou, meer bussen betekent een hoger investerings- vraagstuk natuurlijk en hogere afschrijvingen. En ja, als de opdrachtgever niet meer geld wilt bijleggen, dat betekent dat je in principe minder OV krijgt. Dus de belangrijkste reminder daar is, is dat vergroening niet kosteloos is.

\section{2:8 $\pi 6$ in Transcript C}

Het kan niet voor hetzelfde bedrag, maar dan groen. Er moet dan, gewoon de prijs van vergroening worden betaald. Die moet op enig moment bepaald worden tot alles vergoed $\mathrm{i}$

\section{2:9 16 in Transcript C}

Het eerste is gewoon de investering in nieuw materieel. Twee is dat je van dat nieuwe materieel, wat veel duurder is, ook nog veel meer nodig hebt.. Daarnaast heb je natuurlijk nog andere vormen van duurzame mobiliteit in mijn beleving. Of een op diesel draaiende auto met één persoon erin van a naar b rijdt of in plaats daarvan met twee personen van a en b. Dat is ook een vorm van duurzaam in mijn beleving eh duurzaam is wat mij betreft ook demand responsive transport. 


\section{2:12 If 8 in Transcript C}

Het is een beetje de vraag, dat zal in de praktijk moeten blijken of je dan ook echt minder kilometers gaat rijden over het algemeen. Wat je wel heel snel ziet, is dat klein materieel wordt ingezet, dus dat scheelt een slok op een borrel en dieselbussen verbruiken natuurlijk veel meer dan een acht persoons busje.

\section{2:13 98 in Transcript $C$}

Alleen is het zeg maar dat het een beetje de vraag is of de kleine aantal klanten wat we nu bedienen op de ouderwetse manier, zeg maar of die wel de stap gaan maken naar die nieuwerwetse manier die heel anders functioneert. We hebben de noodzaak van het hebben van een app reserveren, waar een busje.

\section{2:15 If 8 in Transcript C}

Ik denk dat wij nog gaan ontdekken dat het voor de gebruikers die we op het oog hebben, hè, dus de huidige gebruiker van het huidige ouderwetse systeem dat het best wel een hele grote stap kan zijn.

\section{2:17 शा 8 in Transcript C}

Wij gaan dat adopteren, zeg maar die mogelijkheden die er zijn. Ik denk dat daar ook nog wel wat tijd overheen gaat ehm en ik denk dat in het begin ook gaan leren dat het best nog wel complex is om het goed te doen, ook gewoon in de uitvoering. Dus ik denk dat die vorm van duurzaamheid, die gaat de komende twee, drie jaar ook overal uitgerold worden. Ik denk dat we wel gaan ontdekken dat veel mensen nou nog niet echt op zit te wachten, en dat je ook niet zomaar een nieuwe groep reizigers naar het OV krijgt - en dat wordt dan uitdaging op zich want daarmee komt die hele oplossing natuurlijk ook onder druk te staan. Als je iets ouds weghaalt en je vervangt dat voor iets nieuws vanuit een overtuiging dat dat werkt en vervolgens loopt de helft weg, dan ontstaat er natuurlijk enorme druk om dan het oude maar weer terug te halen.

\section{2:18 \10 in Transcript C}

Nou, ik denk het belangrijkste woord is, denk ik, gewoon durf en lef, want de politiek is natuurlijk van nature risicomijdend, hè. We kennen allemaal het gegeven dat dat in principe het erover eens bent dat je iets gaat doen of iets gaat proberen en op het moment dat er dan wat protest komt wat je eigenlijk aan de voorkant allemaal uit kon tekenen. Ja, dan wordt vaak ook weer meteen gezegd dat was niet de bedoeling. Dat is natuurlijk suf, het veroorzaakt onrust. Dan is de politiek als eerste degene die zegt: nou, misschien moeten we toch maar gewoon doen wat we altijd deden, of daar terugkomen en ja, dan ga je, dan ga je er ook nooit achter komen.

\section{2:19 \} 1 0 \text { in Transcript C }}

Je moet daar met het oog op die doelstellingen die je hebt en die zijn gewoon nou van de hoogste horde - zeg maar. Je moet inderdaad gewoon naar die zero emissie toe. Je moet naar duurzaam toe, je moet naar circulair toe. Dat zijn te grote thema's. Zeg maar je moet een keer door de bocht - en ja dat vergt lef, je er letterlijk gewoon een keer doorheen slaan, maar je zult zien dat er altijd weerstand zal zijn en blijft bestaan, en ja, ik denk dat daar een voordeel voor die hele transitie en daarna een risico zit dat men gewoon ja dat en je kunt in één keer soepel door de bocht.

\section{2:24 शा 14 in Transcript C}

Je kunt die consequenties voor jezelf goed inschatten, maar hoe de reiziger dat gaat pikken dat is veel moeilijker in te schatten en dat komt voor een groot deel volgens mij, omdat dat niet echt is aangegeven wat de reiziger precies moet, en daar zit je ook wel weer met het dilemma. Dat is een beetje flauw, want wat ik aanhaal dat heb je ongetwijfeld allemaal vaker gehoord. Je moet niks aan de klanten vragen. Je moet het gewoon doen en dat je dan terug hoort: dat is wat ik wilde. Maar dat krijg je niet te horen als je zegt: wat wil je? Wat willen jullie? Ook klanten denken vaak aan dat wat ze kennen. Dan zeg je eigenlijk wil ik liever dat die bus vier keer per uur gaat, maar wat ze eigenlijk willen is dat ze kunnen reizen als zij willen en vier keer per uur maakt dat min of meer wanneer ze willen. Maar dat spreken ze niet zo uit. Dus het is heel lastig om klanten daar op een goede manier bij te betrekken, denk ik, en dan de goede antwoorden te krijgen of de informatie die je kunt gebruiken ehm doordat gebrek een bepaald referentiekader.

\section{2:27 II 20 in Transcript C}

Alleen ja, het is altijd relatief kleinschalig. Natuurlijk er zijn in het beste geval eens, een keer 100 klanten gevraagd en die geven dan een antwoord op 25 vragen of zo. En daar probeer je dan een conclusie uit te trekken.

\section{2:29 \ा 22 in Transcript C}

Ik denk alleen dat men dreigt snel uit het oog te verliezen, wellicht is dat mensen uiteindelijk altijd maar behoefte 
hebben aan een vorm van mobiliteit. Het is leuk dat er haltes zijn en fietsen en bussen en treinen, maar ik maak gebruik van alle zeg maar dus voor de reiziger blijft het gewoon een overstap van mobiliteitsvorm naar de andere mobiliteit voor. En ik heb soms een beetje het idee in deze discussies nogmaals die nog verder uitgewerkt moeten gaan worden. Dat beeld gaat zich ontwikkelen de komende jaren dat men, als er maar veel is, veel fietsen staan en scooters en acties en bussen en deelfietsen, dan denken mensen, daar moet ik naar toe. Terwijl ik denk van ja, mensen denken van ja, ik moet daar gewoon weer overstappen, dus het is niet zo dat als je maar veel hubs neerzet dat mensen dan denken: "nu ga ik gebruik maken van het openbaar vervoer", want liefst hebben ze natuurlijk gewoon een auto voor de deur.

\section{2:30 \ा 24 in Transcript C}

En dan, want daar hoeven ze niet naar die hub dus die hub is, blijft gewoon een drempel

\section{2:33 \ा 28 in Transcript C}

Dus ik denk dat het daar vooral zit in eigenlijk het omgekeerde, is de kracht om daar te kunnen komen bij die hub? Eh lijnen worden gestrekt. Zeg maar dus dat lijnennet, dat wordt steeds rechter of zo, maar steeds grotere afstanden tot de lijn nemen dus toe of halte van de lijn nemen toe. En ja, dat maakt dat mensen op gegeven moment steeds vaker. Ik pak vaak gewoon de auto, want dan moet ik bijna een kilometer lopen, zeg maar weet je wel en dat kost ook gewoon tijd, hè, je loopt zo een kwartier. Nou, en dan ben je ook niet blij, maar wij hebben alle bekende nadelen van het OV, die hoef hoeft niet te vertellen. Dus dat mensen dus, als je die hub op verschillende manieren kunt benaderd, bijvoorbeeld met een busje wat je ophaalt en je daar trapt of met een elektrische deelfiets die die op de hoek van de straat staat: zo'n carrousel met ons iets ofzo. Ja, dan pak ik daar die fiets. Dan fiets ik snel naar die hub. En dan pak ik daar vervolgens dingen dus ik denk dat daar in het landelijk gebied vooral de aandacht moet zijn die hub. Je moet natuurlijk een beetje goed smoelen, maar hoe is die hub bereikbaar anders dan wordt het gewoon een mooi stuk aangelegd stuk grond in een weiland waar een mooie parkeerplaats is voor de regiotaxi, waar deel fietsen staan, die niemand gebruikt en een mooi informatiezuil en de bus die aan twee kanten wegrijdt. Maar wie komen daar dan? En Hoe?

\section{2:37 \ 30 in Transcript C}

Ik ben nou ook zelf een automobilist, dus ik ben bewust van wat ik zeg, maar die moet je dan gewoon treiteren. Dat is gewoon de beste manier. Om uit de auto te krijgen belonen. Er weegt geen beloning op tegen die van het comfort en gemak van je eigen auto, zeker als die gratis is zoals die ik heb, gewoon een leaseauto. Ik betaal maar niks in totaal geen allerlei.

\section{2:38 शा 36 in Transcript C}

Nou kun je daar nog tegenoverstellen, ja, die mensen die zitten beroepsmatig op de bus, ja dus denk je nou echt dat die dan wel in een vrije tijd ook nog in de bus gaan zitten. Dat geloof ik ook wel een beetje, zien ze zo'n collega weer. Dat voelt misschien als werk, dus dat is misschien toch een beetje van ja, oké, ik sta als kok in een restaurant b, ga ik dan in dit weekend op mijn vrije dag eten in restaurant b weet je wel, dus daar kan ik me wel iets bij voorstellen. Maar toch ja, ja, die mensen hebben gewoon een auto en zelfs die buschauffeur geeft op dat moment de voorkeur aan zijn auto. Dus dat is toch wel heel erg opmerkelijk. Maar als je zelfs die groep met een gratis abonnement aan alle kennis die ze hebben al niet kunt overtuigen om die altijd te laten staan, nou, dan weet je dat je een gewoon hele strijd te gaan hebt.

\section{3:2 \ 2 in Transcript B}

Ikzelf denk dat de grootste uitdaging is om goed in beeld te hebben, te houden, wat zijn de grootste vervoersgroepen waar je ook vormen van openbaar vervoer of vraag gestuurd vervoer maar collectief geregeld kan toepassen?

\section{3:10 शा 32 in Transcript B}

Die zijn eigenlijk vooral vanuit het bedrijfsleven. Hoe zorgen we ervoor dat dat wij onze werkplekken ook bereikbaar zijn? Daar zit eigenlijk een heel grote afstand tussen de plannen en het bestaande aanbod van mobiliteit en de plannen - want die zijn helemaal niet gericht op die bedrijfslocaties. Dus dat is echt een lastige kwestie, hoe krijg je dat nou voor elkaar. Volgens mij niet op deze manier. Ik althans niet, maar ik heb dat niet op de voet gevolgd. Hoe zorgen ervoor dat die bedrijven ook mensen zoeken die nog niet hier werken, wel wonen of niet hier gaan wonen? Dat die ook daadwerkelijk op die plek kunnen komen.

\section{3:14 \ा 40 in Transcript B}

ijk als je, als je dat bedoeld vanuit je kunt alleen maar bedrijven bij OV knooppunten plaatsen. Ja, dat kan. Het 86 
netwerk in de Achterhoek vinden wij alleen te onduidelijk en te vaag en ongestructureerd, dus dat kan never nooit die structurerende werking hebben, kansloos. Wel zijn er wat kansen onbenut op stationslocaties.

\section{3:15 \ 40 in Transcript B}

. Nou ja, die zou wel graag ergens wat woningen voor starters willen hebben bij één van de stations langs die lijn, want dan kunnen mensen ook met de trein naar het werk komen. Dus dat kan, maar het is de toegevoegde waarde van die structurerende werking. Op andere factoren lijkt mij heel beperkt. Ja, daar kun je woningen bouwen, maar op andere plekken ook. En de vraag naar woningen is zo groot. Ja, dat maakt niet het verschil, dat zijn niet de tipping points. Het weegschaaltje is niet dat het doorslaat naar die locatie.

\section{3:21 Tा 58 in Transcript B}

het alternatief voor privé vervoer moet wel in ieder geval van hetzelfde niveau zijn. Dat is het niet snel, dus dat bepaalt ook veel drijfveren van mensen, denk ik dus. Het gaat om veel meer dan om ogenschijnlijk rationele beslissingen.

\section{3:24 \ 68 in Transcript B}

In Doetinchem moet je op de rijbaan - ik heb dat een paar keer gedaan, maar dat, daar ben ik mee gestopt. Dat is echt niet veilig, vooral vanwege het gedrag van automobilisten.

\section{3:26 I 85 in Transcript B}

Als er geen verdienmodel achter zit, dan moet je het ook niet proberen te krijgen. Je hebt tuurlijk verdienmodel van mensen die gewoon of zelf of vanuit hun werkgever mobiliteit bezitten, ergens voor kunnen betalen en die verwachtingen hebben op een bepaald kwaliteitsniveau. Dan heb je een stroom van gesubsidieerde, zeg maar de regiotaxi toestand. Ja, dat is ook een heel ander stramien, dat is dat is op basis van afspraken. Die twee zou je nog met elkaar kunnen vermengen als je het slim organiseert, maar moeten we wel heel goed uitkijken hoe dat zit. En dan heb je die gefragmenteerde verplaatsingen, privé en gebaseerd op vrijwilligheid en heb je natuurlijk wel de vrijwilliger regiotaxi. Ja, ik zou die driedeling wel op één of andere manier in mijn analyse een plek geven.

\section{3:27 \ा 91 in Transcript B}

Dat is heel cruciaal, dus de grootste mobiliteitsproblemen die wij hebben en voor de ontwikkeling van mobiliteit in onze regio. Met daarop aansluitend kunnen wij aansluiten met de bus. Dat zou enorm helpen. De spoorverdubbeling Arnhem Winterswijk, ja, dat zou dat is zo belangrijk, anders kun je bijna niks, als je dat niet voor elkaar krijgt, dat wordt onderschat. Hetzelfde geldt voor de belangrijke spoorverbinding voor de westelijke helft van de Achterhoek, het spoor Zwolle Roosendaal en hoe haken we daaraan? Hoe krijgen we dat nou goed voor elkaar, dus op Zutphen en dieren? Dat is heel belangrijk en is een knetter drukke spoorlijn. Als je daar 's morgens naar de trein stapt, dan kun je aansluiten op het balkon en staan.

\section{4:2 $\mathbb{2} 2$ in Transcript $A$}

. Nou, en het tweede is denk ik wel dat kijk als je kijkt naar elektrisch vervoer en het opladen voor elektrisch vervoer. Daar leeft toch wel een beetje. Denk de gedachte dat het bijna nergens kan, terwijl er toch heel veel plekken in de achterhoek zijn waar het wel kan en die plekken gaan uitbreiden. Zeker vanuit het actieplan laadinfrastructuur. Ik heb het idee dat die dat die bewustwording dat men ook weet dat je overal kunt laden, dat het eigenlijk prima is om hier gewoon ook elektrisch bijvoorbeeld kunnen rijden, ja, dat er is, dus het is vooral gedragsverandering en met name bekendmaking.

\section{5:1 II 13 in Transcript $F$}

De Achterhoek heeft een gebiedsopgave, hè, en die opgave is erop gericht dat in zeg maar het landelijke gebied eh wordt voorkomen dat de bevolking krimpt, vergrijst en dat soort zaken dus, het moet prettig wonen en werken blijven in de Achterhoek, hè en één van de voorwaarden om dat te realiseren is eh het bereikbaar zijn van werklocaties en regionale voorzieningen waar de Achterhoekers gebruik van maken.

\section{5:2 \ 13 in Transcript $F$}

, maar verbinden, veranderen, en vergroenen hebben heel erg te maken met die duurzame mobiliteit

\section{5:8 \ 31 in Transcript $F$}

us naar één de gedragsbeïnvloeding kant. Dat is voor ons gewoon echt nog echt een onbekend terrein. Wat wij ook gewoon nog moeten verkennen, hè. Hoe stimuleer je de reiziger dan om op de juiste manier te gaan reizen. Als wij dat als een oplossing zien. Ja, dan moeten ze er wel gebruik van gaan maken en er zijn voorbeelden in het land. Neem even in Groningen, bijvoorbeeld waar die hubs worden neergezet. Ah, joh, die zit er helemaal gelikt 
uit, maar niemand die er komt. Dat is dan net op de verkeerde locatie. Ja is van tevoren onvoldoende onderzoek gedaan, en dat dat de juiste plek is. Daarvoor is dus gedragsbeïnvloeding zo belangrijke. Ja, dat is wel belangrijk voor de Achterhoek.

\section{5:10 \ 35 in Transcript $F$}

leefbaarheid in dat gebied. Ik denk dat de kans ligt om, als je het op een andere manier organiseert, dat je de gebied beter bereikbaar kan maken en daar dus ook ten gunste van de leefbaarheid. Dat schrijven we ook in de visie, hè. Het is niet meer dat de bereikbaarheid van een gebied het doel is. Nee, we gaan kijken wat de leefbaarheid van dat gebied vergroot, de aantrekkelijkheid voor wonen, bedrijf om zich gaan vestigen en daar ligt nu wel momenteel een mooie kans om dat op een andere manier te organiseren.

\section{5:14 \ 44 in Transcript F}

Daarnaast zijn we een systeem aan het creëren waardoor je eigenlijk ook de verplaatsingen van reizigers ziet. Over de dag heen een heel actueel, dus we zijn aan te kijken of er gewoon door middel van een dashboard ook kunnen zien hoe de reizigers zich te weven en het liefst uit uiteindelijk ook naar een bepaald gebied op bepaalde weg toe $\mathrm{mmm}$. Alleen naast gedragsbeïnvloeding heb je een andere te pakken en dat is data gedreven werken. We zijn als provincie echt bezig van hoe kunnen we nou data gebruiken? Hoe kunnen we beter analyseren, want daar zijn we als overheid niet zo heel goed in. Dus wij hebben veel gesprekken met elkaar. Over het algemeen is het Gelderlands beleid, niet altijd gebaseerd op al die cijfers, want ja die zijn verspreid, hé, wij hebben tot provinciale wegen, maar je hebt natuurlijk ook rijkswegen en je hebt gemeentelijke wegen, dus we zijn echt heel erg aan het kijken van oké kunnen we dan nog verbeteren? Maar op dit moment zijn de onderzoeken er wel naar dat je inderdaad dat trends worden geproduceerd met aantal verplaatsingen per dag actueel en reizigers onderzoeken die we eigenlijk standaard dat doen. En dat is in het openbaar vervoer. En dat is over ook over de wegen. En dan heb je de grote car data, dat zeg je misschien wel wat ja je dat zijn allemaal dingen die wij ook dus daarbij betrekken.

\section{$5: 21$ I 63 in Transcript F}

met wat ze wat ze vanuit de regio willen, en daar ligt een kans om die leefbaarheid van het gebied gewoon echt ja echt te vergroten. Ik denk dat het belangrijk is om telkens de focus te houden van wat er als gebied zijnde gebeurd. Het probleem van krimp zal een uitdaging gaan vormen van: hoe houdt het gebied nog z'n charme als het ware, want ik verwacht dat veel mensen geïnteresseerd zijn om juist met die overvolle Randstad deze kant op te trekken, dus richting de Achterhoek.

\section{6:1 If 4 in Transcript $\mathrm{E}$}

oor de techniek zit er nu een uitdaging in zorgen dat er een in een rolstoel voertuig komt, wat ze voldoende actieradius heeft, en geen uitstoot heeft.

\section{6:8 \ 45 in Transcript E}

Ehm op zich lopen we nu niet ergens tegenaan, behalve dat daar ontzettend lange doorlooptijden zijn, eh misschien dat het meest lastig is, is die komen nu vaak voor vanuit openbaar vervoer en ook wel een taxi is gewoon een andere wereld die kennen elkaar eigenlijk niet, ze weten dat ze bestaan. Ze kennen elkaar niet en spreken ook die taal niet en ja, soms lijkt het dan heel moeilijk, terwijl het misschien makkelijker is, maar openbaar vervoer en taxi zitten toch net iets anders in mekaar. Als je deze mensen dan uiteindelijk bij elkaar zet blijkt het allemaal niet zo spannend zijn, maar dat is wel een uitdaging om die wereld van elkaar te begrijpen.

\section{6:10 \ 64 in Transcript $\mathrm{E}$}

Ehm, want dat kan toch niet zo zijn dat iemand in Duitsland vervoerd wordt voor de kosten van de provincie Gelderland was het verhaal, dat is iemand die zelfs in een thuis kan bij ons gewoon rit boeken. En dat is die van Winterswijk, want dat kan de provincie in Arnhem niet begrijpen en dat ik zeg: ja, maar iemand die uit Enschede komt, en dat willen wij graag. Mag dat wel, dan wil ik mag zijn. Wat is nou het verschil tussen iemand uit Enschede of Duitsland? Dus dat ze wel willen, maar niet snappen hoe het echt in elkaar zit. Die grens bestaat natuurlijk eigenlijk niet. Nee, zo op deze kleine schaal voorzie je wel in een behoefte. Het is een hele kleine behoefte. Ongeveer 1000 ritten naar Duitsland op de 250000, maar juist het aandeel binnen die ik die niet Wmo is, is relatief groot, dus daar is wel de behoefte ehm. We mogen alleen niet in Duitsland vervoeren, hè dus je mag naar Duitsland, je mag van Duitsland hierheen, maar binnen Duitsland mogen wij niet vervoeren. Ik weet wel dat een kreis Borken, wel eens gevraagd heeft van, hoe doe je eigenlijk het vervoer, dan zouden we daar wat van kunnen leren, dus dat is op zich wel interessant. Ja, de spanning is natuurlijk niet zo hoog, dus in het grensgebied. 


\section{6:12 \ 102 in Transcript $\mathrm{E}$}

Nu reizen mensen op zich ook wel, maar doen dat alleen met een indicatie. Ze kunnen niet alle ritten met openbaar vervoer maken. Het is gewoon winst inhalen zonder dat je de mensen beknot in hun mobiliteit. Wij mogen geen hoger tarief berekenen dan het openbaar vervoer, want dat zou oneerlijk zijn. Ja, iemand heeft een Wmo, dus je moet op dezelfde manier kunnen reizen als iemand die dat niet heeft. We kijken naar de achterhoek. Hoeveel mensen kunnen er met het openbaar vervoer reizen? En voor welke afstanden? Niet overal komt een bus, en als je meer dan $20 \mathrm{~km}$ reist dan betaal je meteen de hoofdprijs.

\section{6:14 П 128 in Transcript $E$}

Het is dat zowel bij het rijk, hoewel misschien in tegenstelling wat ik net zijn, maar ook bij de provincie, wel dat alles hetzelfde moet zijn en juist door die technologische ontwikkelingen die apps is. Maar de vraag of dat nou echt wel goed is.

\section{6:15 श 130 in Transcript E}

In de achterhoek hebben wij daar ideeën over om van onderaf, vanuit bedrijven ideeen op te pakken. Op deze manier - en dat is een provincie dat die dan zegt van ja, maar dan is het anders wel in Arnhem of in de foodvalley. $\mathrm{Ja}$, en dat willen we niet ehm. Ja, dat is, dat zit er diep in op de één of andere manier, maar dat zit bijvoorbeeld ook bij een ROCOV, ziet dat er heel diep in. Het moet overal hetzelfde zijn. ledereen, het snappen dat dat volgens mij wordt dat achterhaald straks de mensen reizen, ook niet op die manier door heel Nederland zichzelf al je.

$\nabla$ Communication

3 Groups:

Behaviour / Development / Organisation

1 Quotations:

\section{6:8 \ 45 in Transcript $\mathrm{E}$}

Ehm op zich lopen we nu niet ergens tegenaan, behalve dat daar ontzettend lange doorlooptijden zijn, eh misschien dat het meest lastig is, is die komen nu vaak voor vanuit openbaar vervoer en ook wel een taxi is gewoon een andere wereld die kennen elkaar eigenlijk niet, ze weten dat ze bestaan. Ze kennen elkaar niet en spreken ook die taal niet en ja, soms lijkt het dan heel moeilijk, terwijl het misschien makkelijker is, maar openbaar vervoer en taxi zitten toch net iets anders in mekaar. Als je deze mensen dan uiteindelijk bij elkaar zet blijkt het allemaal niet zo spannend zijn, maar dat is wel een uitdaging om die wereld van elkaar te begrijpen.

$\otimes$ Demands from stakeholders

O Groups

24 Quotations:

\section{1:39 1 31 in Transcript D}

Ze worden goed gebruikt, maar ze hadden nog veel beter gebruikt kunnen worden, maar in ieder geval. Wij hadden inderdaad te verwachten dat we dat sowieso al verder konden uitrollen de komende jaren. Misschien moeten we die verwachting iet wat bijstellen, maar er is wel heel veel animo voor, dus er zijn heel veel ondernemingen, ook bij toeristische attracties, bijvoorbeeld die zoiets hebben van hé: 'Dit is een leuk concept, kunnen wij daar ook iets mee? Kunnen wij daar ook risicodeling inzitten om ervoor te zorgen dat die fietsen hier staan?' Dus ja, die animo, die is er zeker en dan merk je ook steeds meer en daar zijn we ook actief mee bezig. Om dat verder uit te rollen.

\section{2:3 $\mathbb{2} 2$ in Transcript $C$}

Dat batterijbussen een beperkte actieradius hebben in vergelijking met dieselbussen, en dat die ook voortdurend dus aan de stekker moeten, zeg maar om het volgende stuk te kunnen rijden

\section{2:7 96 in Transcript C}

Nou, meer bussen betekent een hoger investerings- vraagstuk natuurlijk en hogere afschrijvingen. En ja, als de opdrachtgever niet meer geld wilt bijleggen, dat betekent dat je in principe minder OV krijgt. Dus de belangrijkste reminder daar is, is dat vergroening niet kosteloos is.

\section{2:15 श 8 in Transcript $C$}

Ik denk dat wij nog gaan ontdekken dat het voor de gebruikers die we op het oog hebben, hè, dus de huidige gebruiker van het huidige ouderwetse systeem dat het best wel een hele grote stap kan zijn.

Een contract wordt getekend voor 15 jaar. Ja, hoe realistisch is om te denken dat je na tien jaar nog precies dat 
contract zo moet invullen zoals het geschreven is, hè dus die die contracten daar staan natuurlijk vaak eisen met betrekking tot de ontsluiting van kernen, het verhaal van 400 meter, iedere bewoner 400 meter tot een halte, het openbaar vervoer tot middernacht. Ja, dat is hartstikke mooi dat je dat vastlegt voor 15 jaar en ik snap wel dat je daar iets over wilt vastleggen, omdat je je ook, ja, iedereen een gelijk speelveld wilt hebben. ledereen weet waar die aan toe is.

\section{2:24 \I 14 in Transcript C}

Je kunt die consequenties voor jezelf goed inschatten, maar hoe de reiziger dat gaat pikken dat is veel moeilijker in te schatten en dat komt voor een groot deel volgens mij, omdat dat niet echt is aangegeven wat de reiziger precies moet, en daar zit je ook wel weer met het dilemma. Dat is een beetje flauw, want wat ik aanhaal dat heb je ongetwijfeld allemaal vaker gehoord. Je moet niks aan de klanten vragen. Je moet het gewoon doen en dat je dan terug hoort: dat is wat ik wilde. Maar dat krijg je niet te horen als je zegt: wat wil je? Wat willen jullie? Ook klanten denken vaak aan dat wat ze kennen. Dan zeg je eigenlijk wil ik liever dat die bus vier keer per uur gaat, maar wat ze eigenlijk willen is dat ze kunnen reizen als zij willen en vier keer per uur maakt dat min of meer wanneer ze willen. Maar dat spreken ze niet zo uit. Dus het is heel lastig om klanten daar op een goede manier bij te betrekken, denk ik, en dan de goede antwoorden te krijgen of de informatie die je kunt gebruiken ehm doordat gebrek een bepaald referentiekader.

\section{2:25 \ा 14 in Transcript C}

Als je het 100 mensen gaat vragen krijg je 100 verschillende antwoorden, daar zit ik niet op te wachten 2:28 शा 22 in Transcript C

Ik denk dat ja, ga 'k zeggen, ieder halte is een aansluiting op het netwerk per definitie, dus ik denk dat waar het naartoe gaat is dat het na de variëteit van dienst die wordt geboden rondom de mobiliteitsdienst, terwijl het bestaande, maar ook wellicht nog andere diensten dat dat op een gegeven moment bepaalt of er sprake is van een hub.

\section{2:45 \ा 52 in Transcript C}

ik denk dat je dan mogelijk ook het moment bereikt waarop mensen MaaS-mobiliteit inderdaad hebben ontdekt. Arriva is een partij die investeert, maar dat zijn heel veel partijen die daarin investeren, ook allemaal met een business case eronder. Als ik heel eerlijk ben, denk ik dat veel mensen daarin nog wel teleurgesteld gaan raken, de eerste jaren in relatie tot de verwachte opbrengsten, omdat je volgens mij toch altijd te positief wordt gedacht. Over die gedrag is aanpassingen. Mensen zitten vast in bepaalde gedragingen. Die zijn er echt niet zomaar uit te krijgen, ook al heb je goede tools en goede middelen, en het OV zelf is daarvan een prima voorbeeld. Dat hebben het net ook al besproken, want ze gaan echt niet zomaar van af. Ik denk dat daar de verwachtingen wel wat overspannen zijn, maar dat je dus inderdaad over 10-15 jaar.lk denk nee, maar over tien 15 jaar kan ik me voorstellen dat mensen wel bereid zijn om die gedrag aanpassing op zichzelf toe te gaan passen en dat men dat gaat ontdekken. En ik geloof ik echt in een sneeuwbaleffect. Niemand doet het, dus ik doe het ook niet totdat je in je omgeving op een gegeven moment mensen ziet die dat doen en die je meenemen samen. Kijk je dit aan, oké, oh, dat is eigenlijk zo makkelijk. Nou, en op een gegeven moment, dan ben je om, want die omgeving heb je voldoende mensen die doen. Dus je hebt bepaalde voorbeeldfunctie is. En dan pak je dat op en ik denk dat we over tien 15 jaar wel ongeveer zo ver zijn dat mensen Maas.

\section{3:10 \ 32 in Transcript B}

Die zijn eigenlijk vooral vanuit het bedrijfsleven. Hoe zorgen we ervoor dat dat wij onze werkplekken ook bereikbaar zijn? Daar zit eigenlijk een heel grote afstand tussen de plannen en het bestaande aanbod van mobiliteit en de plannen - want die zijn helemaal niet gericht op die bedrijfslocaties. Dus dat is echt een lastige kwestie, hoe krijg je dat nou voor elkaar. Volgens mij niet op deze manier. Ik althans niet, maar ik heb dat niet op de voet gevolgd. Hoe zorgen ervoor dat die bedrijven ook mensen zoeken die nog niet hier werken, wel wonen of niet hier gaan wonen? Dat die ook daadwerkelijk op die plek kunnen komen.

\section{3:11 Iा 34 in Transcript B}

Misschien ook wel één van de meest opmerkelijke uitkomsten is dat mensen hier zo dicht bij hun werk wonen. Dus dat betekent - en dat zie je ook op een industrieterrein, heel veel mensen op de fiets of met de auto omdat ze gewoon autorijden leuk vinden of niet. Daar waar het veronderstelde probleem zit dat is bij nieuwe medewerkers, ook jonge medewerkers, hoe krijg je die nou op de werkplek? En hoe gaan mensen ook zien dat werkplekken 90 
ergens op een industrieterrein in Steenderen of Hengelo of Ulft of zo, dat dat ook een optie is als je in Arnhem zit en dan kom je daar daardoor. Als je dan een auto hebt, dan is ook best wel weer een afstand en tijd hebben. Ook kan je natuurlijk met het OV, maar heel veel werk locaties zijn helemaal niet bereikbaar met het OV. Zo kan je ook vragen aan ondernemers: wat denken jullie dat kansrijk is? Kun je ook samenwerken als bedrijf om iets van een pendeldienst ofzo te laten draaien? Het OV systeem is daar vrij slecht op ingericht.

\section{3:13 ๆ 36 in Transcript B}

echnisch kan iets aantrekkelijk zijn - en dat is heel simpel, kan gewoon een soort app zijn of zo, maar het kan ook zijn het bedrijf een beetje collectief vervoer met elkaar organiseren, busjes heen en weer laten tussen bepaalde logische opstappunten. Dat kan ook een deel van het mobiliteitsaanbod worden.

\section{3:15 \ 40 in Transcript B}

. Nou ja, die zou wel graag ergens wat woningen voor starters willen hebben bij één van de stations langs die lijn, want dan kunnen mensen ook met de trein naar het werk komen. Dus dat kan, maar het is de toegevoegde waarde van die structurerende werking. Op andere factoren lijkt mij heel beperkt. Ja, daar kun je woningen bouwen, maar op andere plekken ook. En de vraag naar woningen is zo groot. Ja, dat maakt niet het verschil, dat zijn niet de tipping points. Het weegschaaltje is niet dat het doorslaat naar die locatie.

\section{3:18 \ा 48 in Transcript B}

drie vier belangrijkste vervoersmotieven en zoek naar de kansrijke onderdelen van het verplaatsen en probeer daar nieuwe vervoersconcepten of mobiliteitsaanpak in te ontwikkelen. En moet dat dan duurzaam zijn of niet? Ja, dat ligt er naar het vertrekpunt van je beleid, dat is een keuze dat kan. Maar ja, er is natuurlijk niks op tegen, dus ik wil daar niks van af doen. Dat is een belangrijk beleidsmotief: je moet je wel realiseren dat als je wil aansluiten bij de leefwereld van de reiziger dat dat niet per se hoeft te betekenen dat die reiziger ook heel graag een duurzaam mobiliteitsalternatief wil.

\section{3:25 \ 72 in Transcript B}

ik vind die drie $O$ samenwerking rondom het thema mobiliteit niet zo ver ontwikkeld. Eerlijk gezegd is het nog een aardig beleid gedomineerde thema tafel. De ambtenaren hebben daar nog wel een grote invloed, zeg maar en de bestuurders dus. De betrokkenheid van ondernemers is eigenlijk nog veel te weinig. Maar het zoeken naar een vorm van mobiliteitscoöporatie of coöperatieve structuur, dat vind ik dan wel echt vernieuwend en dat is ook wel vernieuwend vergeleken met de rest van het land. Maar goed, het is een idee op papier dus eerst maar eens zien dan we geloven. Dus laten we eens kijken of we hebben dat ze gewoon te krijgen. Ik denk dat het nog wel echt de grootste slag is die geslagen moet worden. Dat is dat je ook wel mobiliteitsvragen van het bedrijfsleven, moet betrekken, misschien als opdrachtgever. Ja, heel praktisch lijn 82 is gaat naar Doetinchem langs Steenderen. Die maakt een lus om Steenderen heen. Precies langs bepaalde bedrijven. Dan is het belangrijk dat je als locatie goed bereikbaar bent. Maar dat is niet met een gestrekte buslijn. Dus als je goede opstappunten creert, met een vorm van collectief vervoer. Dat zou ik interessant vinden, daarmee kijk je wat goed aansluit bij wat dan daadwerkelijk de behoefte is voor die werknemer, van die werkgever.

\section{4:3 $\mathbb{4} 4$ in Transcript A}

a, op een aantal manieren, ik denk dat het vanuit werkgevers dat dat een hele mooie aanpak is, dat veel mensen die wonen in de achterhoek, eigenlijk ook in de achterhoek, niet iedereen, maar een heel groot deel. Wel, dus die ga je echt bereiken als je de werkgevers hier ook meekrijgt. Daar hebben we nu mee bezig met mobiliteit makelaars. 4:7 \ 29 in Transcript A

De overheid kunnen niet zelf fietsen gaan exploiteren, want dan gaan we natuurlijk volledig langs alle regels in die we landelijk hebben gesteld, maar wachten tot een aanbieder zich aanbiedt zoals Urbee. Ja, dat heeft ook geen zin. Kijk, je krijgt ook echt wel wat geld voor het feit dat die fietsen staan. We hebben je doet ook mee, dus we hebben ook gezegd van ja, we gaan niet die fietsen volledig betalen. Jij moet ook zelf risicodragend meedoen, maar de toeristische sector risico dragen bij.

\section{5:4 II 19 in Transcript F}

hub, En dat je kijkt naar hoe je ervoor kan zorgen dat je een bepaalde plek creëert waar je bepaalde stroom bij elkaar kan laten komen, hè dat je dat ook op een bepaalde slimme manier goed organiseert, maar ook vormen van mobiliteit zijn belangrijk in dat gebied, hè of inderdaad, dat eh. Nou ja, wat wij noemen we dan nu de hub, taxi ofwel het ov-vangnet. Ja, dat is ook in zo'n gebied weer belangrijk, dus je bent veel meer ook aan schakelen, ook 
een hele andere opgave. Het is belangrijk dat we de HEt bewoners ook bereikbaar kunnen houden en wat ik ook al zei, ook gewoon de keus te maken om ook niet tot het uiterste te gaan in het aanbieden. En dat staat in onze visie ook niet allemaal. Het aanbieden van alle vormen van mobiliteit, maar vooral de meest geschikte.

\section{5:9 1 31 in Transcript $F$}

Het OV vermijden - en dat is voor ons als opdrachtgever van het openbaar vervoer echt ja een hoofdpijndossier, momenteel hè. Van hoe hou je het openbaar vervoer levend? Hoe zorg je dat de vervoerders nog in gaan schrijven en nog met openbaar vervoer überhaupt gaan rijden? Maar ook op langere termijn verwachten we juist dat de Achterhoek wat meer vol gaat lopen en dat mensen meer thuis gaan werken, dus dat bedrijven, maar ook mensen uit de Randstad, dit een aantrekkelijk gebied gaan vinden

\section{5:20 \ा 62 in Transcript $F$}

Dus we moeten ook meedenken met wat fijnmazig netwerk aan hubs en dat soort zaken

\section{5:21 \ा 63 in Transcript F}

met wat ze wat ze vanuit de regio willen, en daar ligt een kans om die leefbaarheid van het gebied gewoon echt ja echt te vergroten. Ik denk dat het belangrijk is om telkens de focus te houden van wat er als gebied zijnde gebeurd. Het probleem van krimp zal een uitdaging gaan vormen van: hoe houdt het gebied nog z'n charme als het ware, want ik verwacht dat veel mensen geïnteresseerd zijn om juist met die overvolle Randstad deze kant op te trekken, dus richting de Achterhoek.

\section{6:3 99 in Transcript $\mathrm{E}$}

In de basis zijn er twee vormen, dat is de vraagafhankelijk, het deel wat jij nu noemt, van zorg op maat, waarbij mensen dus gewoon kunnen. Dat doen we hoofdzakelijk voor mensen die daar recht op hebben. Vanuit de Wmo, maar ook ieder ander kan dat doen, omdat de provincie dat belangrijk vind. Provincie wil dat wel veranderen, waarbij je ze nu nog zeggen: je mag mensen van deur tot deur voeren. Gaat het op termijn naar het halte tot halte.

\section{6:4 I 21 in Transcript $E$}

$\mathrm{Ja}$, dat hangt een beetje van af, want als de provincie toch denken aan een systeemwijziging, hoeveel zin heeft het dan nog, want dan weet je wat we nu hebben. Ik had het graag uitgevoerd.

\section{6:14 \ 128 in Transcript $E$}

Het is dat zowel bij het rijk, hoewel misschien in tegenstelling wat ik net zijn, maar ook bij de provincie, wel dat alles hetzelfde moet zijn en juist door die technologische ontwikkelingen die apps is. Maar de vraag of dat nou echt wel goed is.

$\nabla$ Effiency

2 Groups:

Development / Mobility

15 Quotations:

\section{1:43 \ा 47 in Transcript D}

En daarbij willen we die die hoofdlijnen die die de nou liggen - ik had het in het begin al gezegd - die zijn heel dun ehm. Die willen we in ieder geval goed te houden. Maar willen we wel voor zorgen dat ze 's avonds en dan merk je s avonds, wordt er heel weinig gebruikgemaakt van het OV en met name de bus dan dat die niet onnodig moeten gaan rijden. Dat is gewoon zonde en geld weggooien, en dat vindt ook arriva.

\section{1:44 \/ 47 in Transcript D}

We hebben ook ZOOV die zich inzet voor Wmo voor doelgroepenvervoer die nu dus ook al bepaalde ritten voor arriva oppakt. Als het nodig is, dan hoeft er geen hele bus te rijden, maar dan kan er een busje van gaan rijden, en dat willen we eigenlijk. Het liefst verder uitrollen, zodat zon grote bus zo 's avonds niet per se beschikbaar moet zijn en moet rondrijden puur en alleen omdat we die lijn in stand moeten houden. Nee, dat zou bijvoorbeeld ook op afvraag kunnen zijn, op oproep kunnen zijn. Daar zijn we ook mee bezig. Proberen we ook goed vorm te geven, want het is gewoon zonde om geld weg te gooien, terwijl dat elders misschien heel goed met elkaar kunt combineren en dan kunt besparen en weer op een andere manier deelvervoer bijvoorbeeld, kunt inzetten

\section{2:1 1 2 in Transcript $C$}

zero emissie. Er zijn nogal wat doelstellingen of ehm. De doelstelling van diverse partijen is zeg maar een hele belangrijke. In het zero-emissie akkoord staat dat vanaf 2025 er geen nieuwe bussen meer instromen als die niet zero emissie zijn en dat vanaf 2030 alle busvervoer in de regio 's zero emissie is dus dat brengt dan nou 92 
ja in enorme investeringen, vraagstukken met zich mee, maar niet alleen een investering, vraagstuk, maar ook het vraagstuk van techniek en kennis, ontwikkelingen rondom techniek. Veel mensen zijn ingegeven door wat ze bijvoorbeeld met name ook in het zuiden, in het westen van het land zien en daar rijdt al veel zero emissie busvervoer. Dat zijn eigenlijk allemaal batterij bussen gewoon, ja, net als de Tesla, zeg. We hebben dat ook voor bussen. Het is alleen wat minder goed bekend. Dat batterijbussen een beperkte actieradius hebben in vergelijking met dieselbussen, en dat die ook voortdurend dus aan de stekker moeten, zeg maar om het volgende stuk te kunnen rijden. En dat betekent dat er niet alleen in bussen moet geïnvesteerd worden, maar ook in de infrastructuur. Laadpunten, gewoon letterlijk laadpunten, net zoals je dat ook voor auto's langs de snelweg laadpunten of gewoon ergens in de stad laadpalen hebt. Dat is voor bussen niet anders. Alleen gaat daar nog veel meer geld in om en je beperkt je daarmee ook heel erg op twee manieren: je moet rijden, daar waar je kunt, maar je lijnnetwerk leg je heel erg vast en je snapt dat als je ergens investeert in een laadpunt op een bepaalde plek in je provincie en je steekt daar 4000000 euro in dat mensen niet willen horen dat je volgend jaar ergens anders gaat rijden. Zeg maar, want dan denk ik: 'ja, hallo'. We hebben daar een beetje hetzelfde dilemma. Wat je nu ook op kleinere schaal hebt met bushaltes die op hoogte gebracht worden dat mensen makkelijk kunnen instappen, ja, als je dan vervolgens zegt van tegen de gemeente, en we gaan hier niet meer halteren. Dan zeggen zij ook, we hebben daar met een ton een verhoging aangelegd.

\section{2:6 96 in Transcript $C$}

Nou, het busvervoer is in de afgelopen 2030 jaar enorm veel efficiënter geworden, ook doordat men kans heeft gezien die bus eigenlijk gewoon altijd te laten rijden. Er zijn concessies bekend waarvan de werkplaats soms met de handen in het haar zitten, omdat die bus nooit binnenkomt. Je rijdt bij wijze van spreken van de 24 uur rijdt die 23 uur dus qua efficiency is dat perfect.

\section{2:9 1 6 in Transcript $C$}

Het eerste is gewoon de investering in nieuw materieel. Twee is dat je van dat nieuwe materieel, wat veel duurder is, ook nog veel meer nodig hebt.. Daarnaast heb je natuurlijk nog andere vormen van duurzame mobiliteit in mijn beleving. Of een op diesel draaiende auto met één persoon erin van a naar b rijdt of in plaats daarvan met twee personen van a en b. Dat is ook een vorm van duurzaam in mijn beleving eh duurzaam is wat mij betreft ook demand responsive transport.

\section{2:10 \} 6 \text { in Transcript C }}

Wat je nu nog veel ziet: het is gewoon historisch zo gegroeid, bussen rijden gewoon hun rondjes tot tien uur 's avonds, 11 uur 's avonds, 12 uur 's avonds, een beetje afhankelijk van de concessie-eisen maar ja, rijdt gewoon één keer per half uur alle haltes af. Over het algemeen is er één chauffeur en 40 lege stoeltjes, en die doet dat braaf tot $z$ 'n dienst voorbij is.

\section{2:11 98 in Transcript $C$}

Je rijdt alleen als er ook daadwerkelijk een vraag is.

\section{2:12 \ा 8 in Transcript C}

Het is een beetje de vraag, dat zal in de praktijk moeten blijken of je dan ook echt minder kilometers gaat rijden over het algemeen. Wat je wel heel snel ziet, is dat klein materieel wordt ingezet, dus dat scheelt een slok op een borrel en dieselbussen verbruiken natuurlijk veel meer dan een acht persoons busje.

\section{2:20 \} 1 0 \text { in Transcript C }}

Een contract wordt getekend voor 15 jaar. Ja, hoe realistisch is om te denken dat je na tien jaar nog precies dat contract zo moet invullen zoals het geschreven is, hè dus die die contracten daar staan natuurlijk vaak eisen met betrekking tot de ontsluiting van kernen, het verhaal van 400 meter, iedere bewoner 400 meter tot een halte, het openbaar vervoer tot middernacht. Ja, dat is hartstikke mooi dat je dat vastlegt voor 15 jaar en ik snap wel dat je daar iets over wilt vastleggen, omdat je je ook, ja, iedereen een gelijk speelveld wilt hebben. ledereen weet waar die aan toe is.

\section{3:7 श 22 in Transcript B}

kijk in mobiliteitsbeleid en onderzoek gaat het vaak over efficiëntie. Dit is natuurlijk niet waar reizigers mee bezig zijn. Reizigers gaat het gewoon om comfortabel van de plek van herkomst naar de plek van bestemming te gaan. En dan gaat het gaat soms ook om heel andere dingen: voorkeuren of statussymbool, of het plezier van de verplaatsing. 


\section{3:8 Iा 24 in Transcript B}

De waarde die daarbij een rol gaat spelen en het beleid, mensen en onderzoek denken vaak dat het om efficiency gaat ten koste technisch moet het goed zijn. En zo ja, dan zou je nooit openbaar vervoer hebben. Eerlijk gezegd, het is hartstikke inefficiënt

\section{4:1 1 2 in Transcript A}

Dus dat bedrijven, dus werkgevers bijvoorbeeld, en uiteindelijk natuurlijk de mensen die zelf reizen naar hun werk, dat ze zich veel meer bewust zijn van hè. Als ik de autopark is dat minder duurzaam dan de fiets kijk, we zijn er achter, ook heel erg gewend om van onze eigen vervoersmiddelen gebruik te maken. Fietsen, een auto op motor, maar je ziet ook wel dat de stap naar de verduurzaming daarin.

\section{5:14 II 44 in Transcript F}

Daarnaast zijn we een systeem aan het creëren waardoor je eigenlijk ook de verplaatsingen van reizigers ziet. Over de dag heen een heel actueel, dus we zijn aan te kijken of er gewoon door middel van een dashboard ook kunnen zien hoe de reizigers zich te weven en het liefst uit uiteindelijk ook naar een bepaald gebied op bepaalde weg toe $\mathrm{mmm}$. Alleen naast gedragsbeïnvloeding heb je een andere te pakken en dat is data gedreven werken. We zijn als provincie echt bezig van hoe kunnen we nou data gebruiken? Hoe kunnen we beter analyseren, want daar zijn we als overheid niet zo heel goed in. Dus wij hebben veel gesprekken met elkaar. Over het algemeen is het Gelderlands beleid, niet altijd gebaseerd op al die cijfers, want ja die zijn verspreid, hé, wij hebben tot provinciale wegen, maar je hebt natuurlijk ook rijkswegen en je hebt gemeentelijke wegen, dus we zijn echt heel erg aan het kijken van oké kunnen we dan nog verbeteren? Maar op dit moment zijn de onderzoeken er wel naar dat je inderdaad dat trends worden geproduceerd met aantal verplaatsingen per dag actueel en reizigers onderzoeken die we eigenlijk standaard dat doen. En dat is in het openbaar vervoer. En dat is over ook over de wegen. En dan heb je de grote car data, dat zeg je misschien wel wat ja je dat zijn allemaal dingen die wij ook dus daarbij betrekken.

\section{5:15 950 in Transcript $F$}

We gaan niet met de lijntjes die er nu rijden. Kunnen wij niet, dan kunnen we niet concurreren als iemand er vervolgens een auto krijgt, dus we proberen inderdaad veel meer te kijken naar wat is nou functie van een bepaald gebied? Hoe creëer je een stroom? Hoe kun je die bij elkaar pakken, waardoor je een aantal buslijnen ook gewoon kan opheffen en dat budget kan gebruiken om er een veel sterkere van te maken en dan goed te kijken welke vooren natransport mogelijkheden kun je dan het beste de beste bieden? En dan kan dat past van mij wat ons betreft de auto zijn maar dan veel minder reisafstand die met de auto hoeft af te leggen.

\section{6:15 \ 130 in Transcript $E$}

In de achterhoek hebben wij daar ideeën over om van onderaf, vanuit bedrijven ideeen op te pakken. Op deze manier - en dat is een provincie dat die dan zegt van ja, maar dan is het anders wel in Arnhem of in de foodvalley. $\mathrm{Ja}$, en dat willen we niet ehm. Ja, dat is, dat zit er diep in op de één of andere manier, maar dat zit bijvoorbeeld ook bij een ROCOV, ziet dat er heel diep in. Het moet overal hetzelfde zijn. ledereen, het snappen dat dat volgens mij wordt dat achterhaald straks de mensen reizen, ook niet op die manier door heel Nederland zichzelf al je.

Q Flexibility vs guarantees

1 Groups:

Behaviour

1 Quotations:

\section{2:14 If 8 in Transcript C}

ie vraagt ook een stukje flexibiliteit van de gebruiker. Die moet daar ook een beetje mee om kunnen gaan versus die zekerheid van nou ja, is daar kwart over gaan staan dan komt vier vijf minuten later komt de bus. Mocht het een keer tegenvallen is die tien minuten later, maar hij komt wel heel vaak, negen van de tien keer ja, en dat is toch een hele andere manier van reizen, en ik denk dat die eigenlijk iedereen in de branche die gelooft waarin alle opdrachtgever, alle mensen die er omheen zitten, of het nou Moventem is of een universiteit. Die geloven daar wel in.

$\otimes$ Goals

2 Groups:

Development / Organisation

1 Quotations:

94 


\section{5:13 \ 43 in Transcript $F$}

Laten we zeggen, hè dus ja, het is eigenlijk dat we met mekaar aan het zoeken zijn van hoe kunnen we nou een totaal mobiliteitsconcept maken die aan al die behoeftes voldoet en er zullen ongetwijfeld auto's over de N18 blijven rijden? Dat is ook niet ons doel, hè. Om dat niet meer mogelijk te maken.

$\otimes$ Infrastructure

1 Groups:

Infrastructure

15 Quotations:

\section{1:7 II 2 in Transcript D}

ook het netwerk van laadinfrastructuu

\section{1:8 $\mathbb{\text { I }} 2$ in Transcript D}

algemeen dekkende infrastructuur is. Dus dat is regio breed en al ja, dat is ontzettend lastig om dat goed uit te rollen, om dat ook toekomstbestendig te maken en op dat dan ook te combineren met de bedrijven die het uiteindelijk moeten gaan leggen, want daar wordt overal aanspraak op gemaakt

\section{1:41 T 39 in Transcript D}

Misschien kunnen we die parkeerplaatsen, die daar zijn inrichting volgende tot een laadpunten. En daar zijn we dus ook mee bezig - zijn ook bezig met een regionale visie van laadinfrastructuur. En daaronder zijn dan ook een gemeentelijke visie, laadinfrastructuur.

\section{2:1 1 2 in Transcript $C$}

zero emissie. Er zijn nogal wat doelstellingen of ehm. De doelstelling van diverse partijen is zeg maar een hele belangrijke. In het zero-emissie akkoord staat dat vanaf 2025 er geen nieuwe bussen meer instromen als die niet zero emissie zijn en dat vanaf 2030 alle busvervoer in de regio 's zero emissie is dus dat brengt dan nou ja in enorme investeringen, vraagstukken met zich mee, maar niet alleen een investering, vraagstuk, maar ook het vraagstuk van techniek en kennis, ontwikkelingen rondom techniek. Veel mensen zijn ingegeven door wat ze bijvoorbeeld met name ook in het zuiden, in het westen van het land zien en daar rijdt al veel zero emissie busvervoer. Dat zijn eigenlijk allemaal batterij bussen gewoon, ja, net als de Tesla, zeg. We hebben dat ook voor bussen. Het is alleen wat minder goed bekend. Dat batterijbussen een beperkte actieradius hebben in vergelijking met dieselbussen, en dat die ook voortdurend dus aan de stekker moeten, zeg maar om het volgende stuk te kunnen rijden. En dat betekent dat er niet alleen in bussen moet geïnvesteerd worden, maar ook in de infrastructuur. Laadpunten, gewoon letterlijk laadpunten, net zoals je dat ook voor auto's langs de snelweg laadpunten of gewoon ergens in de stad laadpalen hebt. Dat is voor bussen niet anders. Alleen gaat daar nog veel meer geld in om en je beperkt je daarmee ook heel erg op twee manieren: je moet rijden, daar waar je kunt, maar je lijnnetwerk leg je heel erg vast en je snapt dat als je ergens investeert in een laadpunt op een bepaalde plek in je provincie en je steekt daar 4000000 euro in dat mensen niet willen horen dat je volgend jaar ergens anders gaat rijden. Zeg maar, want dan denk ik: 'ja, hallo'. We hebben daar een beetje hetzelfde dilemma. Wat je nu ook op kleinere schaal hebt met bushaltes die op hoogte gebracht worden dat mensen makkelijk kunnen instappen, ja, als je dan vervolgens zegt van tegen de gemeente, en we gaan hier niet meer halteren. Dan zeggen zij ook, we hebben daar met een ton een verhoging aangelegd.

\section{2:4 \ा 4 in Transcript C}

at is een belangrijke, die infrastructuur die wordt over het algemeen niet aangelegd door de vervoerder die wordt aangelegd door gemeente, provincie, energiemaatschappijen. Dus dat maakt wel weer een soort ja noodzakelijk vorm van samenwerking, maar ook van investering.

\section{2:7 96 in Transcript C}

Nou, meer bussen betekent een hoger investerings- vraagstuk natuurlijk en hogere afschrijvingen. En ja, als de opdrachtgever niet meer geld wilt bijleggen, dat betekent dat je in principe minder OV krijgt. Dus de belangrijkste reminder daar is, is dat vergroening niet kosteloos is.

\section{2:42 \} 4 6 \text { in Transcript C }}

Dat wordt veel te lastig en dan komt een waterstof bus in beeld, omdat die een grotere actieradius hebben en die qua gebruik veel dichter bij de operationele gebruikt veel dichter bij een diesel bus. Je denkt dat vol tien minuten, net als mijn bus en dan rijdt ie 400 kilometer voordat ie weer aan de aan de pomp komt. Net als deze op is is het 
beste kan verder, maar hij komt qua gebruik, is gevoelsmatig gewoon een diesel bus, maar dan wel met een die die die veel zuipt, om het zo maar te zeggen met een wat kortere actieradius. En dat is de reden van met name in het streekvervoer wordt er heel erg gekeken naar waterstofbussen en eh. Tegelijkertijd weet je dat batterij ook steeds grotere actieradius krijgen. Steeds lichter, steeds meer vermogen hebben voor kleinere batterijen. Dus wij hebben bij altijd ook gezien de eerste je 150 kilometer rijden. Nu haal je 500 à 600 dus daar zal ongetwijfeld ook weer een stap in worden gemaakt. En het is een beetje de vraag. Maar als je op dit moment in de streek zou moeten rijden met batterij bussen, dan heb je wel een serieus probleem en daar komen we dus die waterstof dus van nou.

\section{2:43 \ा 48 in Transcript C}

Nou ik denk dat je nooit helemaal zeker als techniek en een beetje in de ontwikkelingsfase zijn, je blind moet staren op één techniek. Ik denk dat je dat gewoon niet kunt. Voorlopig gebruiken wij waterstof en zie je wel heel duidelijk dat er twee kampen zijn, bijna hè, batterijen, elektrisch tegen waterstof en andersom

\section{3:3 II 4 in Transcript B}

, want het is niet per se publiek maar kan ook privaat georganiseerd worden, maar de stromende corridor, de route waar bundeling van personenvervoer althans mogelijk is. Ja, dat zou je zou kunnen zeggen nu de belangrijkste spoorverbindingen en de grootste buslijnen. Volgens mij zijn daar nog een paar stappen in te zetten: het strekken van buslijnen, het creëren van een logistiek netwerk.

\section{3:24 \ 68 in Transcript B}

In Doetinchem moet je op de rijbaan - ik heb dat een paar keer gedaan, maar dat, daar ben ik mee gestopt. Dat is echt niet veilig, vooral vanwege het gedrag van automobilisten.

\section{4:2 \ 2 in Transcript A}

. Nou, en het tweede is denk ik wel dat kijk als je kijkt naar elektrisch vervoer en het opladen voor elektrisch vervoer. Daar leeft toch wel een beetje. Denk de gedachte dat het bijna nergens kan, terwijl er toch heel veel plekken in de achterhoek zijn waar het wel kan en die plekken gaan uitbreiden. Zeker vanuit het actieplan laadinfrastructuur. lk heb het idee dat die dat die bewustwording dat men ook weet dat je overal kunt laden, dat het eigenlijk prima is om hier gewoon ook elektrisch bijvoorbeeld kunnen rijden, ja, dat er is, dus het is vooral gedragsverandering en met name bekendmaking.

\section{5:15 \ा 50 in Transcript $F$}

We gaan niet met de lijntjes die er nu rijden. Kunnen wij niet, dan kunnen we niet concurreren als iemand er vervolgens een auto krijgt, dus we proberen inderdaad veel meer te kijken naar wat is nou functie van een bepaald gebied? Hoe creëer je een stroom? Hoe kun je die bij elkaar pakken, waardoor je een aantal buslijnen ook gewoon kan opheffen en dat budget kan gebruiken om er een veel sterkere van te maken en dan goed te kijken welke vooren natransport mogelijkheden kun je dan het beste de beste bieden? En dan kan dat past van mij wat ons betreft de auto zijn maar dan veel minder reisafstand die met de auto hoeft af te leggen.

\section{5:16 \ 52 in Transcript $F$}

Als je bijvoorbeeld een ov-chipkaart hebt bij studenten zijn er ook problemen. Studenten over de grens studeren, of tegen de grens van Duitsland, missen bepaalde vergoedingen. Dus het is ook wel een lastig gebied om dat goed bereikbaar te houden. En de enige manier is om dat inderdaad te bundelen aan bepaalde opgaves van het gebied en die vervoersstromen ook gewoon te bundelen en ook gewoon te realiseren dat je niet iedereen uit die auto kan krijgen.

\section{5:17 ๆ 56 in Transcript $F$}

Ik sprak met onze gedeputeerde nog toevallig hierover, en het enige wat hij noemt is dat er gewoon voor een voorbeeldrol is. Wij willen gewoon met die tien waterstofbussen. Ja, dat zet geen zoden aan de dijk. Dat zijn die elektrische bussen die nu inderdaad in de IJssel vecht concessie rijden. Ja, weet je, dat zijn er een groot aantal. Daar bereik je echt iets in. Die energietransitie alleen dan ook niet heel veel, hè.

\section{6:2 \ 6 in Transcript E}

Dat moet dan ook opgeladen worden en het verkrijgen van die laadinfrastructuur is ook nog een complexe opgaan. Dus dat zijn in de techniek denk ik de uitdagingen.

$\otimes$ knowledge

1 Groups:

Development

96 
1 Quotations:

2:23 शा 14 in Transcript C

Maar ik heb het idee dat in Nederland er, vooral door kennis dragers mensen zoals jij in en ik, anders wordt geanalyseerd, gekeken naar cijfers, naar ontwikkelingen, naar trends in andere business dan die van ons.

$\triangle$ MaaS

1 Groups:

Mobility

16 Quotations:

1:22 \ा 8 in Transcript D

etmobiel. Nou, hogeschool Saxion, die is daar daarmee aan de slag om daar een app voor op te stellen in samenwerking met ons en vele andere partijen die nou niet allemaal de hoofdrolspeler zijn. Als het goed volgens mij.

\section{1:23 शा 11 in Transcript D}

Netmobiel die verzorgt straks een app waarin ook is verwerkt waarin ook deelvoertuigen op dit moment modaliteiten zijn verwerkt, OV is verwerkt en dergelijke om alles te koppelen met betrekking op Maas, en OV binnen de Achterhoek. Dus dat zou echt onze eigen app worden, waarmee al die duurzame vormen van mobiliteit worden verenigd, maar ook het rit delen. En wij verwachten ook dat daar binnen de Achterhoek heel veel kansen liggen.

\section{1:24 \ा 13 in Transcript D}

Dat vraagt ook gewoon echt om campagnes en in die campagnes willen wij ook echt duidelijk maken dat bijvoorbeeld een deelauto die wij nou in de kern hebben staan.

\section{1:42 \ा 45 in Transcript D}

netmobiel, het wordt ontwikkeld, maar zo'n app, bijvoorbeeld, heel simpel, stel je bent slecht te been. Je kunt via de app straks ook gewoon een rit aanvragen: en dan zou je kunnen zeggen van ik moet van hier naar hier en ik moet wel weer terug. Dan zou je dat kunnen zien en sowieso rit gewoon kunnen accepteren. Met die app zou je dan ook voor punten kunnen sparen. Krediet als het ware, is geen gewoon geld, maar krediet kun je aan een goed doel geeft, maar kun je inderdaad ook uiteindelijk voor gebruiken om erin te gebruiken.

\section{2:13 98 in Transcript $C$}

Alleen is het zeg maar dat het een beetje de vraag is of de kleine aantal klanten wat we nu bedienen op de ouderwetse manier, zeg maar of die wel de stap gaan maken naar die nieuwerwetse manier die heel anders functioneert. We hebben de noodzaak van het hebben van een app reserveren, waar een busje.

\section{2:32 \ा 26 in Transcript C}

Ik denk dat daar de grootste kracht zit voor hubs ehm mensen daar afzetten, waarna ze die laatste twee, drie kilometer op in een variëteit van manieren kunnen invullen.

\section{2:45 \ 52 in Transcript C}

ik denk dat je dan mogelijk ook het moment bereikt waarop mensen MaaS-mobiliteit inderdaad hebben ontdekt. Arriva is een partij die investeert, maar dat zijn heel veel partijen die daarin investeren, ook allemaal met een business case eronder. Als ik heel eerlijk ben, denk ik dat veel mensen daarin nog wel teleurgesteld gaan raken, de eerste jaren in relatie tot de verwachte opbrengsten, omdat je volgens mij toch altijd te positief wordt gedacht. Over die gedrag is aanpassingen. Mensen zitten vast in bepaalde gedragingen. Die zijn er echt niet zomaar uit te krijgen, ook al heb je goede tools en goede middelen, en het OV zelf is daarvan een prima voorbeeld. Dat hebben het net ook al besproken, want ze gaan echt niet zomaar van af. lk denk dat daar de verwachtingen wel wat overspannen zijn, maar dat je dus inderdaad over 10-15 jaar.lk denk nee, maar over tien 15 jaar kan ik me voorstellen dat mensen wel bereid zijn om die gedrag aanpassing op zichzelf toe te gaan passen en dat men dat gaat ontdekken. En ik geloof ik echt in een sneeuwbaleffect. Niemand doet het, dus ik doe het ook niet totdat je in je omgeving op een gegeven moment mensen ziet die dat doen en die je meenemen samen. Kijk je dit aan, oké, oh, dat is eigenlijk zo makkelijk. Nou, en op een gegeven moment, dan ben je om, want die omgeving heb je voldoende mensen die doen. Dus je hebt bepaalde voorbeeldfunctie is. En dan pak je dat op en ik denk dat we over tien 15 jaar wel ongeveer zo ver zijn dat mensen Maas.

$3: 2$ ๆ 2 in Transcript B

Ikzelf denk dat de grootste uitdaging is om goed in beeld te hebben, te houden, wat zijn de grootste vervoersgroepen 
waar je ook vormen van openbaar vervoer of vraag gestuurd vervoer maar collectief geregeld kan toepassen? 4:4 9 \% in Transcript A

Uiteindelijk kan iedereen gebruik maken van netmobiel Moet je voorstellen, netmobiel is een app met een platform waar een rit delen als belangrijk component in de app zit. Dus ik weet dat ik met dat ik met jou mee kan rijden of andersom, maar daarnaast gaan we in die app. Ook de deelauto's die we nu aan het neerzetten zijn, worden geïntegreerd. We hebben al deel fietsen, die komen er ook in en ook openbaar vervoer. Ook ZOOV komt daarin dus het wordt gewoon een MaaS app hè, dat is waar we naartoe willen en uiteindelijk iedereen daar gebruik van gaat maken waar we met netmobiel in de pilot zegmaar dadelijk als eerste ons op zullen richten. Dat zijn met name de ouderen in het dorp die dus geen eigen vervoersmiddel hebben, of mensen die bijvoorbeeld geen tweede auto hebben en daardoor ook soms geen eigen vervoer hebben om iets verder te gaan dan het dorp zelf en die dus mee kunnen rijden met andere die dat wel hebben. Maar ook jongeren mogen daar gewoon gebruik te maken, hoor dus je mag iedereen gebruik maken van net mobiel.

\section{4:5 शा 16 in Transcript A}

Kijk uiteindelijk heeft Gelderland inderdaad in de visie: mobiliteit hubs, die pakken wij als regio op. Dus daarom is netmobiel een project voor ons in het hele aanbod zou ik eigenlijk willen zeggen dus mobiliteit hubs, ja, daar zijn we nu al mee bezig. We gaan een inventarisatie doen nu ook van waar willen we? Welke hubs? Wat zien we ook als kans daarin hè in die gradatie die Gelderland daarin gemaakt heeft? Rurale hubs, regionale hubs, enzovoorts en welke voorzieningen willen we daar dan?

\section{5:7 II 25 in Transcript F}

Dus eh een hub speelt daar een rol en in onze rol vanuit de visie voor Gelderland is vooral gericht op regionale, hubs en stadsrand hubs en wij vragen aan de regio om na te denken aan meer rurale hubs, een fijnmazig netwerk van hubs, hè. Zij denken aan mobility hubs, waarbij je in ieder geval twee eh modaliteiten op elkaar laat aansluiten. Dus we hebben daar een wat andere visie bij. En ja dus eh om gewoon ook die reiziger te helpen, maar ook te verleiden om dan daar gebruik van te maken. En dat gebeurt ook al. Het probleem is een beetje Covid-19, hè, want rit delen in de Achterhoek is ook een belangrijk aandachtspunt, hè, dus ze zijn ook bezig samen met eh, om een systeem binnen dat Maas op de alleen ja rit delen van en ook nog van ouderen, hè, want het is gericht op ouderen in kleine kernen. Dat is op dit moment de een beetje lastig. Laten we zeggen, maar het is nog steeds de ambitie om dat verder ook op te pakken.

\section{5:12 \ 41 in Transcript $F$}

net Netmobiel hè, en dat is natuurlijk in eerste instantie gericht op delen in de kleine kernen. Er zit een heel plan achter om dat verder uit te rollen als een olievlek in de hele Achterhoek, hè. Het is de bedoeling om Winterswijk aan te haken, en volgend jaar gaan nog weer twee andere gemeenten aanhaken. Er zit een beetje een belemmering in dat het verhaal, hè, maar eh in het hele Netmobiel eh is het van groot belang dat er een soort van community vorming plaatsvindt en dat zou je kunnen zeggen van nou, dat is de reiziger of dat is degene die zich wil verplaatsen, hè en zeg maar die uitwerking is heel erg gericht op die mobiliteitsbehoefte die in beeld wordt gebracht. Netmobiel heeft nu ook een toolkit ontwikkeld om die community vorming zeg maar ook in de in de rest van de Achterhoek eh op te gaan pakken. Maar als je het hebt over treinreizigers en ov-reizigers, dan hebben wij dat natuurlijk ook al vrij veel van in beeld. Dat is wel de basis van waaruit we werken.

\section{6:6 \ 37 in Transcript $\mathrm{E}$}

Dus toen zijn we aan het kijken of we daarmee dus ja voor meerdere partijen kunnen rijden. Eigenlijk zou iedereen in theorie beter van kunnen worden, want de reiziger kan meer vervoer aangeboden krijgen, bijvoorbeeld ook over hoe Elk half uur in plaats van Elk uur ehm de exploitatiekosten dalen. Maar je hebt ook al die grote lege dieselbussen niet meer op straat.

\section{6:7 II 39 in Transcript E}

wij zijn er van begin af aan betrokken. Wij zitten nu in netmobiel als een soort van als je wel de heenreis hebt weten te regenen met iemand die jou wil brengen, maar je komt er niet mee thuis en er rijdt ook geen bus nou, dan kun je netmobiel gebruiken. De discussie is nu wat dat dan zou mogen kosten, maar dat is een hele ander ding. Technisch kan dat gewoon. Wij zijn ook nu bezig om het boeken van ritten via een app te laten plaatsvinden. Dus dat zowel dus Arriva met een nieuwe app dat je daar ook gelijk ritten kan boeken. Maar dat kan er ook voor Netmobiel gelden 
In de achterhoek hebben we een vrij stevig idee wat wij zouden willen. Daar werken we samen als overheden met de vervoerders, maar ook met andere bedrijven binnen de achterhoek ambassadeurs. Nee, dat gaat wel goed, want daar zitten we ook. We proberen ook al die eindjes aan elkaar te knopen. Ook het mobiliteitsportaal is bijna klaar voor de achterhoek. We hebben netmobiel. Wij zijn het gesprek aan het voeren met arriva, maar dat zit allemaal aan elkaar, want de arriva zit ook weer in Netmobiele. We zijn ook wel een handjevol mensen, dus die weten precies van elkaar en zijn op de hoogte dan gaat denk ik wel goed. Ehm voor de Rijksoverheid die is volgens mij niet zo geïnteresseerd wat wij hier aan het doen zijn ehm. Ze hebben natuurlijk MaaS pilots. Ja, wij zijn waarschijnlijk de eerste die het klaar hebben. Daar kunnen we van profiteren, in die zin dat bijvoorbeeld arriva de laatste Maas pilot in Groningen Drenthe heeft gewonnen, die ook gaat over Wmo vervoer. Dus ja, wat zij daar ontwikkelen kan hier gelijk toegepast worden.

\section{6:11 102 in Transcript E}

Je moet een vervoerssystemen neerzetten in de achterhoek waar iedereen mee kan rijden, inclusief vervoerssysteem waar jij en ik ook gebruik van kunnen maken waar mensen die in een plek wonen waar geen bus komt, dat die ook gewoon op dezelfde manier kunnen reizen.

Q Mobiliteitsmakelaars

1 Groups:

Organisation

2 Quotations:

\section{1:17 If 6 in Transcript D}

Ook hebben we een hoop mobiliteitmakelaars in de Achterhoek lopen die ook bij bedrijven langsgaan om hen te helpen met het energievraagstuk en met de duurzaamheidsvraagstukken van kunnen jullie binnen je bedrijf misschien wel verbeteren

\section{4:3 \ 4 in Transcript A}

a, op een aantal manieren, ik denk dat het vanuit werkgevers dat dat een hele mooie aanpak is, dat veel mensen die wonen in de achterhoek, eigenlijk ook in de achterhoek, niet iedereen, maar een heel groot deel. Wel, dus die ga je echt bereiken als je de werkgevers hier ook meekrijgt. Daar hebben we nu mee bezig met mobiliteit makelaars. $\otimes$ National government

1 Groups:

Organisation

1 Quotations:

\section{6:9 II 49 in Transcript $\mathrm{E}$}

In de achterhoek hebben we een vrij stevig idee wat wij zouden willen. Daar werken we samen als overheden met de vervoerders, maar ook met andere bedrijven binnen de achterhoek ambassadeurs. Nee, dat gaat wel goed, want daar zitten we ook. We proberen ook al die eindjes aan elkaar te knopen. Ook het mobiliteitsportaal is bijna klaar voor de achterhoek. We hebben netmobiel. Wij zijn het gesprek aan het voeren met arriva, maar dat zit allemaal aan elkaar, want de arriva zit ook weer in Netmobiele. We zijn ook wel een handjevol mensen, dus die weten precies van elkaar en zijn op de hoogte dan gaat denk ik wel goed. Ehm voor de Rijksoverheid die is volgens mij niet zo geïnteresseerd wat wij hier aan het doen zijn ehm. Ze hebben natuurlijk MaaS pilots. Ja, wij zijn waarschijnlijk de eerste die het klaar hebben. Daar kunnen we van profiteren, in die zin dat bijvoorbeeld arriva de laatste Maas pilot in Groningen Drenthe heeft gewonnen, die ook gaat over Wmo vervoer. Dus ja, wat zij daar ontwikkelen kan hier gelijk toegepast worden.

$\otimes$ Noaberschap

2 Groups:

Mobility / Organisation

1 Quotations:

\section{4:9 1 39 in Transcript A}

Dus je probeert door dat eigenaarschap laag te leggen, natuurlijk al een soort van hè, dat noaberschap was dan ook wel vaak genoemd wordt, maar dat gevoel te creëren van het is ik, ik ben onderdeel van de club. Zou ik bijna zeggen, dus het voelt niet zozeer als ik ben klant, maar ik ben meer lid. Dat is toch een verschil.

$\nabla$ Opinion 
1 Groups:

Behaviour

21 Quotations:

1:4 $\Upsilon$ I 2 in Transcript D

, is dat mensen echt afhankelijk zijn van hun eigen aut

1:5 ๆ 2 in Transcript D

De Achterhoekers zijn echte autorijders en om dat zo duurzaam mogelijk te maken...

\section{1:17 \ 6 in Transcript D}

Ook hebben we een hoop mobiliteitmakelaars in de Achterhoek lopen die ook bij bedrijven langsgaan om hen te helpen met het energievraagstuk en met de duurzaamheidsvraagstukken van kunnen jullie binnen je bedrijf misschien wel verbeteren

\section{1:21 If 8 in Transcript D}

En dan hoeft niet per se met een deelauto te zijn die in het bezit is van meerdere mensen, maar dat zou ik bijvoorbeeld ook in het rit delen kunnen zetten. Dus het delen van ritten

\section{2:14 Iा 8 in Transcript C}

ie vraagt ook een stukje flexibiliteit van de gebruiker. Die moet daar ook een beetje mee om kunnen gaan versus die zekerheid van nou ja, is daar kwart over gaan staan dan komt vier vijf minuten later komt de bus. Mocht het een keer tegenvallen is die tien minuten later, maar hij komt wel heel vaak, negen van de tien keer ja, en dat is toch een hele andere manier van reizen, en ik denk dat die eigenlijk iedereen in de branche die gelooft waarin alle opdrachtgever, alle mensen die er omheen zitten, of het nou Moventem is of een universiteit. Die geloven daar wel in.

\section{2:16 \ 8 in Transcript C}

Het zou me niks verbazen als we daar in eerste instantie vooral ook reizigers nog gaan verliezen en dat er misschien best nog wel wat tijd overheen gaat voordat er weer een soort nieuwe aanwas komt van reizigers die niet overweg konden met het oude systeem. En dan niet omdat ze het niet begrepen of werkt, maar omdat het ja, ik moet dit om kwart over een, kwart voor, ik wil om half ongeveer, en voor die mensen is er nu geen oplossing

\section{2:17 If 8 in Transcript C}

Wij gaan dat adopteren, zeg maar die mogelijkheden die er zijn. Ik denk dat daar ook nog wel wat tijd overheen gaat ehm en ik denk dat in het begin ook gaan leren dat het best nog wel complex is om het goed te doen, ook gewoon in de uitvoering. Dus ik denk dat die vorm van duurzaamheid, die gaat de komende twee, drie jaar ook overal uitgerold worden. Ik denk dat we wel gaan ontdekken dat veel mensen nou nog niet echt op zit te wachten, en dat je ook niet zomaar een nieuwe groep reizigers naar het OV krijgt - en dat wordt dan uitdaging op zich want daarmee komt die hele oplossing natuurlijk ook onder druk te staan. Als je iets ouds weghaalt en je vervangt dat voor iets nieuws vanuit een overtuiging dat dat werkt en vervolgens loopt de helft weg, dan ontstaat er natuurlijk enorme druk om dan het oude maar weer terug te halen.

\section{2:18 $\mathbb{1} 10$ in Transcript C}

Nou, ik denk het belangrijkste woord is, denk ik, gewoon durf en lef, want de politiek is natuurlijk van nature risicomijdend, hè. We kennen allemaal het gegeven dat dat in principe het erover eens bent dat je iets gaat doen of iets gaat proberen en op het moment dat er dan wat protest komt wat je eigenlijk aan de voorkant allemaal uit kon tekenen. Ja, dan wordt vaak ook weer meteen gezegd dat was niet de bedoeling. Dat is natuurlijk suf, het veroorzaakt onrust. Dan is de politiek als eerste degene die zegt: nou, misschien moeten we toch maar gewoon doen wat we altijd deden, of daar terugkomen en ja, dan ga je, dan ga je er ook nooit achter komen.

\section{2:21 Tा 10 in Transcript C}

Want als er een visie wordt ontwikkeld dan dat moment kun je natuurlijk niks doen, want je, je bent nog bezig met de visie. Dus het eerste wat men doet zodra die klaar is meteen beginnen met een nieuwe voor mij. Dit is wat kritisch, maar dat is echt mijn visie op wat één van de probleem is om steeds verder te komen dat men te veel blijft hangen in het praten over en discussiëren over en het toekomstbeelden, samenstellen, visie, enzovoort, enzovoort. Op een gegeven moment moet je gewoon een keer aan de slag en dan komt die weerstand. En dan komt dus ook ja, de koudwatervrees zeg maar ja en dan het stokt het ja. En dan sta je eigenlijk weer terug bij af, zeg maar. Dat is de grootste uitdaging voor duurzaam: is ook lef van alle partijen. Ook vervoerders natuurlijk hè, want zeker als 100 
je als je de eerste bent of zo ja, je kunt ook vreselijk op je bek gaan.

\section{2:29 \ा 22 in Transcript C}

Ik denk alleen dat men dreigt snel uit het oog te verliezen, wellicht is dat mensen uiteindelijk altijd maar behoefte hebben aan een vorm van mobiliteit. Het is leuk dat er haltes zijn en fietsen en bussen en treinen, maar ik maak gebruik van alle zeg maar dus voor de reiziger blijft het gewoon een overstap van mobiliteitsvorm naar de andere mobiliteit voor. En ik heb soms een beetje het idee in deze discussies nogmaals die nog verder uitgewerkt moeten gaan worden. Dat beeld gaat zich ontwikkelen de komende jaren dat men, als er maar veel is, veel fietsen staan en scooters en acties en bussen en deelfietsen, dan denken mensen, daar moet ik naar toe. Terwijl ik denk van ja, mensen denken van ja, ik moet daar gewoon weer overstappen, dus het is niet zo dat als je maar veel hubs neerzet dat mensen dan denken: "nu ga ik gebruik maken van het openbaar vervoer", want liefst hebben ze natuurlijk gewoon een auto voor de deur.

\section{2:34 930 in Transcript C}

de verstokte automobilist? Daar moet je geen geld aan besteden in de vorm van campagnes, want dat is gewoon weggegooid geld. De argumenten die je over het algemeen aanhalen waarom ze geen gebruik van het openbaar vervoer zijn niet vaak niet de echte argumenten, want als je het argument wegneemt dan komt er vervolgens wel een ander argument. Het zijn gewoon voor de hand liggende smoesjes, en men gaat daar gewoon niet op overstappen, tenzij het op een gegeven moment wordt gedwongen, hè, dus de binnenstad wordt afgesloten voor autoverkeer. Of zo ja, dan wordt het een ander verhaal. Ik denk ook dat het meest krachten heeft inderdaad om mensen te overtuigen dat het dat het gewoon een prima manier is om te reizen.

\section{2:35 \ा 30 in Transcript C}

Veel collega's van mij overigens ook met niks in om op die sociaal recreatieve reizigers hebben, met name bij evenementen, vind je ook die mensen die eigenlijk nooit in het OV te vinden zijn. Of het nou Koningsdag is dat de gay parade, gay pride in Amsterdam of Koningsdag bevrijdingsfestival in Wageningen. Die gaan naar de formule één in Zandvoort massaal met de trein. Op dat moment staat met men echt verholpen. Zeg maar, en ik heb mij altijd verbaasd moet zeggen: de laatste jaren gaat het veel beter, hoe wij dat vaak als een gemiste kans hoe dat dan mee omgaan. In het verleden was het dus zo van 'we gaan toch geen extra bus of trein inzetten?!'. Ofzo weet je wel, en dan werd het een chaos. Ja, je maximaal mensen moeten op op het moment dat ze dan een keer het OV gebruiken. En dan gaat het vaak om de treinen. Ook dan moet je dus ook gewoon die beleving geven dat het gewoon hé.

\section{2:41 ๆ 44 in Transcript C}

Daar moet je doorheen breken, maar als je in een traditioneel beroepsgroep zit, zeg maar of over business, zoals het openbaar vervoer. Ja, dan is het heel moeilijk om met dat soort mechanisme te kunnen en mogen werken, zeg maar.

\section{2:45 \ा 52 in Transcript C}

ik denk dat je dan mogelijk ook het moment bereikt waarop mensen MaaS-mobiliteit inderdaad hebben ontdekt. Arriva is een partij die investeert, maar dat zijn heel veel partijen die daarin investeren, ook allemaal met een business case eronder. Als ik heel eerlijk ben, denk ik dat veel mensen daarin nog wel teleurgesteld gaan raken, de eerste jaren in relatie tot de verwachte opbrengsten, omdat je volgens mij toch altijd te positief wordt gedacht. Over die gedrag is aanpassingen. Mensen zitten vast in bepaalde gedragingen. Die zijn er echt niet zomaar uit te krijgen, ook al heb je goede tools en goede middelen, en het OV zelf is daarvan een prima voorbeeld. Dat hebben het net ook al besproken, want ze gaan echt niet zomaar van af. Ik denk dat daar de verwachtingen wel wat overspannen zijn, maar dat je dus inderdaad over 10-15 jaar.lk denk nee, maar over tien 15 jaar kan ik me voorstellen dat mensen wel bereid zijn om die gedrag aanpassing op zichzelf toe te gaan passen en dat men dat gaat ontdekken. En ik geloof ik echt in een sneeuwbaleffect. Niemand doet het, dus ik doe het ook niet totdat je in je omgeving op een gegeven moment mensen ziet die dat doen en die je meenemen samen. Kijk je dit aan, oké, oh, dat is eigenlijk zo makkelijk. Nou, en op een gegeven moment, dan ben je om, want die omgeving heb je voldoende mensen die doen. Dus je hebt bepaalde voorbeeldfunctie is. En dan pak je dat op en ik denk dat we over tien 15 jaar wel ongeveer zo ver zijn dat mensen Maas.

\section{3:5 920 in Transcript B}

En of dat allemaal duurzaam is, dan moet je je afvragen. Kijk, je kan iedereen opjagen, met elektrische auto's, maar ik weet eerlijk gezegd niet of dat nou echt duurzaam is 


\section{3:6 \ 20 in Transcript B}

Het gaat vooral om nieuwe mogelijkheden om mobiliteit te organiseren of aanbod en vraag van mobiliteit bij elkaar te brengen, en ik denk dat daar de focus eerlijk gezegd op ligt. Of we dat nou goed doen voor de auto, een belangrijk vervoersmiddel, evengoed als de fiets, of voor de speed pedelec - daar kun je ook grote afstanden mee overbruggen. Dus daar zit vooral veel technologische ontwikkeling in mobiliteit en een belangrijk deel van de aandacht gaat uit naar hoe benutten we die nieuwe vormen van technologie.

\section{3:9 \ 30 in Transcript B}

Volgens mij wordt gewoon gekeken naar het benutten van technologische mogelijkheden en een nieuwe innovaties, en dat dat beter zou zijn, of dat wat we nu hebben anders in stand zou kunnen blijven. Daar hoor ik niemand over, dus of dat heel expliciet überhaupt een rol speelt, dat weet ik eerlijk gezegd niet.

\section{3:16 \ा 46 in Transcript B}

Nou, het laat wel zien wat een enorme impact het heeft op parkeren in Utrecht, want dat is erg duur, en dat dwingt inderdaad sommige mensen tot een soort leefstijl zonder auto.

\section{3:19 \ 51 in Transcript B}

Mensen zijn kennelijk bereid heel veel geld uit te geven en ook als je een fiets koopt

\section{3:20 ๆ 54 in Transcript B}

Als ik met de trein reis dan heb ik mijn laptop klepje open, dan kan ik gewoon werken. Het kan in een bus niet. Dat is heel onhandig is. Als ik de bus zou willen nemen dan moet je eerst een half uur in die bus die slingert dan eerst over allerlei bruggetjes en bochtige wegen. Buitengewoon ongemakkelijk als je in die bus zit, je wordt er bijna misselijk van. Nou, dan ga je op de hoofdweg, dat zou je kunnen doen. Alleen dan zit ik net zo graag in mijn auto. Dat snap ik wel, want het gaat dan ook efficiënter. Rechtstreekse dus maar goed, ik spreek uit eigen ervaring -ik reis heel veel met openbaar vervoer, althans in mijn vorige werk, de trein eersteklas, want daar kun je tenminste fatsoenlijk zitten en fatsoenlijk werken. Maar niet in de tweede klas, met allemaal lawaai.

\section{4:3 \ा 4 in Transcript A}

a, op een aantal manieren, ik denk dat het vanuit werkgevers dat dat een hele mooie aanpak is, dat veel mensen die wonen in de achterhoek, eigenlijk ook in de achterhoek, niet iedereen, maar een heel groot deel. Wel, dus die ga je echt bereiken als je de werkgevers hier ook meekrijgt. Daar hebben we nu mee bezig met mobiliteit makelaars. Q Opportunity

1 Groups:

Development

23 Quotations:

\section{1:6 \ 2 in Transcript D}

Mensen echt bewust maken van hé, ga elektrisch rijden of misschien wel in de toekomst, waterstof rijden en dat zullen we waarschijnlijk ook bij het vrachtvervoer zien.

\section{1:16 \ा 6 in Transcript D}

Thuiswerken promoten we dus ook

\section{1:20 \ 8 in Transcript D}

bepaald middel ligt en voldoende aanbod is van deelauto's, dan is het voor mensen zich helemaal niet nodig om zo'n auto aan te schaffe

\section{1:44 \ा 47 in Transcript D}

We hebben ook ZOOV die zich inzet voor Wmo voor doelgroepenvervoer die nu dus ook al bepaalde ritten voor arriva oppakt. Als het nodig is, dan hoeft er geen hele bus te rijden, maar dan kan er een busje van gaan rijden, en dat willen we eigenlijk. Het liefst verder uitrollen, zodat zon grote bus zo 's avonds niet per se beschikbaar moet zijn en moet rondrijden puur en alleen omdat we die lijn in stand moeten houden. Nee, dat zou bijvoorbeeld ook op afvraag kunnen zijn, op oproep kunnen zijn. Daar zijn we ook mee bezig. Proberen we ook goed vorm te geven, want het is gewoon zonde om geld weg te gooien, terwijl dat elders misschien heel goed met elkaar kunt combineren en dan kunt besparen en weer op een andere manier deelvervoer bijvoorbeeld, kunt inzetten

\section{2:22 114 in Transcript C}

maar ik heb ook in brede zin gewoon wel het idee dat de reiziger er eigenlijk relatief weinig bij wordt betrokken. 
Dat op zich wel een conclusie zou kunnen zijn: ja, als je 100 verschillende motieven hebt zou dat betekenen dat je dus maximaal custom-made moet maken

\section{2:31 ๆ 24 in Transcript C}

dus dat je meer keus hebt

\section{2:32 \ा 26 in Transcript C}

Ik denk dat daar de grootste kracht zit voor hubs ehm mensen daar afzetten, waarna ze die laatste twee, drie kilometer op in een variëteit van manieren kunnen invullen.

\section{2:33 \ा 28 in Transcript C}

Dus ik denk dat het daar vooral zit in eigenlijk het omgekeerde, is de kracht om daar te kunnen komen bij die hub? Eh lijnen worden gestrekt. Zeg maar dus dat lijnennet, dat wordt steeds rechter of zo, maar steeds grotere afstanden tot de lijn nemen dus toe of halte van de lijn nemen toe. En ja, dat maakt dat mensen op gegeven moment steeds vaker. Ik pak vaak gewoon de auto, want dan moet ik bijna een kilometer lopen, zeg maar weet je wel en dat kost ook gewoon tijd, hè, je loopt zo een kwartier. Nou, en dan ben je ook niet blij, maar wij hebben alle bekende nadelen van het OV, die hoef hoeft niet te vertellen. Dus dat mensen dus, als je die hub op verschillende manieren kunt benaderd, bijvoorbeeld met een busje wat je ophaalt en je daar trapt of met een elektrische deelfiets die die op de hoek van de straat staat: zo'n carrousel met ons iets ofzo. Ja, dan pak ik daar die fiets. Dan fiets ik snel naar die hub. En dan pak ik daar vervolgens dingen dus ik denk dat daar in het landelijk gebied vooral de aandacht moet zijn die hub. Je moet natuurlijk een beetje goed smoelen, maar hoe is die hub bereikbaar anders dan wordt het gewoon een mooi stuk aangelegd stuk grond in een weiland waar een mooie parkeerplaats is voor de regiotaxi, waar deel fietsen staan, die niemand gebruikt en een mooi informatiezuil en de bus die aan twee kanten wegrijdt. Maar wie komen daar dan? En Hoe?

\section{2:35 \ 30 in Transcript C}

Veel collega's van mij overigens ook met niks in om op die sociaal recreatieve reizigers hebben, met name bij evenementen, vind je ook die mensen die eigenlijk nooit in het OV te vinden zijn. Of het nou Koningsdag is dat de gay parade, gay pride in Amsterdam of Koningsdag bevrijdingsfestival in Wageningen. Die gaan naar de formule één in Zandvoort massaal met de trein. Op dat moment staat met men echt verholpen. Zeg maar, en ik heb mij altijd verbaasd moet zeggen: de laatste jaren gaat het veel beter, hoe wij dat vaak als een gemiste kans hoe dat dan mee omgaan. In het verleden was het dus zo van 'we gaan toch geen extra bus of trein inzetten?!'. Ofzo weet je wel, en dan werd het een chaos. Ja, je maximaal mensen moeten op op het moment dat ze dan een keer het OV gebruiken. En dan gaat het vaak om de treinen. Ook dan moet je dus ook gewoon die beleving geven dat het gewoon hé.

\section{2:39 \ा 38 in Transcript C}

marketing en communicatie de prijs psychologie

\section{2:40 श 40 in Transcript C}

Heel basic maken met prijs psychologie, maar heel simpel is dat niet en dat heeft te maken dat je in die semipublieke sector zit, dat je veel met overheden te maken hebt en die houden niet van dat commerciële en die commerciële slimmigheden en zo. Dat vinden ze eng en wij als vervoerder vinden dat dan ook, zeg maar. We zijn binnen die traditie opgegroeid, terwijl ik denk van ja, jongens, ik heb de mensen maar zo ver gekregen. Dat ze voor een tientje extra mag je eersteklas reizen. Dat doen we dat zoiets simpel als doen we al niet dat gewoon ja, maar aan de andere kant je concurrentie, de auto-industrie, ja die ga je niet vertellen wat het kost gewoon een lekkere sexy meid op die auto gooien, roepen dat het niks kost en dan komen ze later achter dat die daar die niet bij hoort, dat kost klauwen vol geld.

\section{2:41 If 44 in Transcript C}

Daar moet je doorheen breken, maar als je in een traditioneel beroepsgroep zit, zeg maar of over business, zoals het openbaar vervoer. Ja, dan is het heel moeilijk om met dat soort mechanisme te kunnen en mogen werken, zeg maar.

\section{3:9 ๆ 30 in Transcript B}

Volgens mij wordt gewoon gekeken naar het benutten van technologische mogelijkheden en een nieuwe innovaties, en dat dat beter zou zijn, of dat wat we nu hebben anders in stand zou kunnen blijven. Daar hoor ik niemand over, dus of dat heel expliciet überhaupt een rol speelt, dat weet ik eerlijk gezegd niet. 
Kijk, het auto rijden is het meest logische en voor de hand liggende vervoerswijze als je auto kunt rijden, dus als je oud genoeg bent om eem rijbewijs te hebben en als je ook nou niet andere beperking hebt om auto te rijden. En je kan kijken wat een auto nou echt voor de mensen kost.

\section{3:14 ๆ 40 in Transcript B}

ijk als je, als je dat bedoeld vanuit je kunt alleen maar bedrijven bij OV knooppunten plaatsen. Ja, dat kan. Het netwerk in de Achterhoek vinden wij alleen te onduidelijk en te vaag en ongestructureerd, dus dat kan never nooit die structurerende werking hebben, kansloos. Wel zijn er wat kansen onbenut op stationslocaties.

\section{5:6 \ 23 in Transcript $F$}

Alleen dat de uitwerking van wat gaan we dan doen met mekaar in zo'n landelijke regio's? Die is wat anders als in stedelijke regio 's, hè dus enerzijds is ie nog steeds gericht op zeg maar het verbeteren van eh of het versnellen van verbindingen, hè, zowel over de weg als met de fiets. Hè, want dat kun je ook. Dus de doelstelling in de Achterhoek is versnellen van ov-verbindingen en niet het ja, het laten rijden van meer treinen en dat soort dat soort zaken. En dan komt jouw vraag met de hubs. Hubs is volgens mij en volgens de Achterhoek een belangrijk onderdeel in hun aanpak. Slimme mobiliteit, oftewel mobility as a service, eh en de Achterhoek heeft de ambitie om aan te sluiten aan de zeven of acht landelijke Maas pilots. Ze willen de achtste landelijke Maas pilot doen, en dat is eigenlijk: hoe krijg je nou mobility as a service, goed georganiseerd in niet stedelijke regio's en daar zijn ze best wel aardige stappen aan het over aan het maken en daar kan ja kan ik je ook best wel eh wat meer informatie over geven, maar zeker interessant om dan bijvoorbeeld nog een keer zo'n gesprek te doen met JT.

\section{5:7 शा 25 in Transcript $F$}

Dus eh een hub speelt daar een rol en in onze rol vanuit de visie voor Gelderland is vooral gericht op regionale, hubs en stadsrand hubs en wij vragen aan de regio om na te denken aan meer rurale hubs, een fijnmazig netwerk van hubs, hè. Zij denken aan mobility hubs, waarbij je in ieder geval twee eh modaliteiten op elkaar laat aansluiten. Dus we hebben daar een wat andere visie bij. En ja dus eh om gewoon ook die reiziger te helpen, maar ook te verleiden om dan daar gebruik van te maken. En dat gebeurt ook al. Het probleem is een beetje Covid-19, hè, want rit delen in de Achterhoek is ook een belangrijk aandachtspunt, hè, dus ze zijn ook bezig samen met eh, om een systeem binnen dat Maas op de alleen ja rit delen van en ook nog van ouderen, hè, want het is gericht op ouderen in kleine kernen. Dat is op dit moment de een beetje lastig. Laten we zeggen, maar het is nog steeds de ambitie om dat verder ook op te pakken.

\section{5:12 $\mathbb{} 41$ in Transcript $F$}

net Netmobiel hè, en dat is natuurlijk in eerste instantie gericht op delen in de kleine kernen. Er zit een heel plan achter om dat verder uit te rollen als een olievlek in de hele Achterhoek, hè. Het is de bedoeling om Winterswijk aan te haken, en volgend jaar gaan nog weer twee andere gemeenten aanhaken. Er zit een beetje een belemmering in dat het verhaal, hè, maar eh in het hele Netmobiel eh is het van groot belang dat er een soort van community vorming plaatsvindt en dat zou je kunnen zeggen van nou, dat is de reiziger of dat is degene die zich wil verplaatsen, hè en zeg maar die uitwerking is heel erg gericht op die mobiliteitsbehoefte die in beeld wordt gebracht. Netmobiel heeft nu ook een toolkit ontwikkeld om die community vorming zeg maar ook in de in de rest van de Achterhoek eh op te gaan pakken. Maar als je het hebt over treinreizigers en ov-reizigers, dan hebben wij dat natuurlijk ook al vrij veel van in beeld. Dat is wel de basis van waaruit we werken.

\section{5:17 956 in Transcript F}

Ik sprak met onze gedeputeerde nog toevallig hierover, en het enige wat hij noemt is dat er gewoon voor een voorbeeldrol is. Wij willen gewoon met die tien waterstofbussen. Ja, dat zet geen zoden aan de dijk. Dat zijn die elektrische bussen die nu inderdaad in de IJssel vecht concessie rijden. Ja, weet je, dat zijn er een groot aantal. Daar bereik je echt iets in. Die energietransitie alleen dan ook niet heel veel, hè.

\section{5:19 T 60 in Transcript $F$}

Ik denk dat het erg gericht zal zijn op het hoofd fiets netwerk, hè dus daar zijn nog een aantal dingen in te doen. Ik denk dat het voor het wegennet heel beperkt blijft Daar hebben ze ook onze hulp bij nodig. Maar dat zou op dit moment nog heel veel onderzoek zijn en verdere uitwerking. En dan heb je nog een aantal spoorprojecten, hè, we willen ook weer heel graag die regio expres om sneller van uit Winterswijk in Arnhem te zijn, en ze willen een doorkoppeling op het station Zutphen eh van de trein uit Winterswijk in de richting van Apeldoorn. En dat geeft een behoorlijke versnelling eh richting midden in Nederland en Randstad. 


\section{6:11 \ 102 in Transcript $E$}

Je moet een vervoerssystemen neerzetten in de achterhoek waar iedereen mee kan rijden, inclusief vervoerssysteem waar jij en ik ook gebruik van kunnen maken waar mensen die in een plek wonen waar geen bus komt, dat die ook gewoon op dezelfde manier kunnen reizen.

\section{6:17 \ 152 in Transcript $E$}

k gebruik het zelf bijvoorbeeld wel eens die de deelfiets in de achterhoek. Die kun je niet reserveren.

$\otimes$ Organisation

1 Groups:

Organisation

12 Quotations:

\section{1:38 \ा 27 in Transcript D}

Nee, wij willen echt dat die gebruikt gaat worden. Dus wij hadden vooraf ook echt als eis gesteld. Wij willen wel aan de voorzijde, dat jullie net als wij risico delend inzitten, dus ervoor te zorgen dat de krachten gebundeld zijn. Je zet risico delend in. Oké, jullie moeten aan de voorkant zoveel abonnementen of prepaid, goede ET cetera, verkopen om dan quitte te draaien. Nou, dat is volgens ons heel goed model, krachtig inzetten, maar we willen wel die stok achter de deur hebben dat die ook blijft.

\section{2:21 II 10 in Transcript C}

Want als er een visie wordt ontwikkeld dan dat moment kun je natuurlijk niks doen, want je, je bent nog bezig met de visie. Dus het eerste wat men doet zodra die klaar is meteen beginnen met een nieuwe voor mij. Dit is wat kritisch, maar dat is echt mijn visie op wat één van de probleem is om steeds verder te komen dat men te veel blijft hangen in het praten over en discussiëren over en het toekomstbeelden, samenstellen, visie, enzovoort, enzovoort. Op een gegeven moment moet je gewoon een keer aan de slag en dan komt die weerstand. En dan komt dus ook ja, de koudwatervrees zeg maar ja en dan het stokt het ja. En dan sta je eigenlijk weer terug bij af, zeg maar. Dat is de grootste uitdaging voor duurzaam: is ook lef van alle partijen. Ook vervoerders natuurlijk hè, want zeker als je als je de eerste bent of zo ja, je kunt ook vreselijk op je bek gaan.

\section{2:23 \ा 14 in Transcript C}

Maar ik heb het idee dat in Nederland er, vooral door kennis dragers mensen zoals jij in en ik, anders wordt geanalyseerd, gekeken naar cijfers, naar ontwikkelingen, naar trends in andere business dan die van ons.

\section{2:24 \ा 14 in Transcript C}

Je kunt die consequenties voor jezelf goed inschatten, maar hoe de reiziger dat gaat pikken dat is veel moeilijker in te schatten en dat komt voor een groot deel volgens mij, omdat dat niet echt is aangegeven wat de reiziger precies moet, en daar zit je ook wel weer met het dilemma. Dat is een beetje flauw, want wat ik aanhaal dat heb je ongetwijfeld allemaal vaker gehoord. Je moet niks aan de klanten vragen. Je moet het gewoon doen en dat je dan terug hoort: dat is wat ik wilde. Maar dat krijg je niet te horen als je zegt: wat wil je? Wat willen jullie? Ook klanten denken vaak aan dat wat ze kennen. Dan zeg je eigenlijk wil ik liever dat die bus vier keer per uur gaat, maar wat ze eigenlijk willen is dat ze kunnen reizen als zij willen en vier keer per uur maakt dat min of meer wanneer ze willen. Maar dat spreken ze niet zo uit. Dus het is heel lastig om klanten daar op een goede manier bij te betrekken, denk ik, en dan de goede antwoorden te krijgen of de informatie die je kunt gebruiken ehm doordat gebrek een bepaald referentiekader.

\section{3:22 \ा 60 in Transcript B}

Ze hoeven niet uit de auto, dus dat is een belangrijk uitgangspunt. Dit wordt vooral door Europees beleid en landelijk beleid veroorzaakt. Subsidiestroom dus

\section{3:25 \ा 72 in Transcript B}

ik vind die drie $\mathrm{O}$ samenwerking rondom het thema mobiliteit niet zo ver ontwikkeld. Eerlijk gezegd is het nog een aardig beleid gedomineerde thema tafel. De ambtenaren hebben daar nog wel een grote invloed, zeg maar en de bestuurders dus. De betrokkenheid van ondernemers is eigenlijk nog veel te weinig. Maar het zoeken naar een vorm van mobiliteitscoöporatie of coöperatieve structuur, dat vind ik dan wel echt vernieuwend en dat is ook wel vernieuwend vergeleken met de rest van het land. Maar goed, het is een idee op papier dus eerst maar eens zien dan we geloven. Dus laten we eens kijken of we hebben dat ze gewoon te krijgen. Ik denk dat het nog wel echt de grootste slag is die geslagen moet worden. Dat is dat je ook wel mobiliteitsvragen van het bedrijfsleven, moet 
betrekken, misschien als opdrachtgever. Ja, heel praktisch lijn 82 is gaat naar Doetinchem langs Steenderen. Die maakt een lus om Steenderen heen. Precies langs bepaalde bedrijven. Dan is het belangrijk dat je als locatie goed bereikbaar bent. Maar dat is niet met een gestrekte buslijn. Dus als je goede opstappunten creert, met een vorm van collectief vervoer. Dat zou ik interessant vinden, daarmee kijk je wat goed aansluit bij wat dan daadwerkelijk de behoefte is voor die werknemer, van die werkgever.

\section{3:26 ๆ 85 in Transcript B}

Als er geen verdienmodel achter zit, dan moet je het ook niet proberen te krijgen. Je hebt tuurlijk verdienmodel van mensen die gewoon of zelf of vanuit hun werkgever mobiliteit bezitten, ergens voor kunnen betalen en die verwachtingen hebben op een bepaald kwaliteitsniveau. Dan heb je een stroom van gesubsidieerde, zeg maar de regiotaxi toestand. Ja, dat is ook een heel ander stramien, dat is dat is op basis van afspraken. Die twee zou je nog met elkaar kunnen vermengen als je het slim organiseert, maar moeten we wel heel goed uitkijken hoe dat zit. En dan heb je die gefragmenteerde verplaatsingen, privé en gebaseerd op vrijwilligheid en heb je natuurlijk wel de vrijwilliger regiotaxi. Ja, ik zou die driedeling wel op één of andere manier in mijn analyse een plek geven.

\section{4:9 II 39 in Transcript A}

Dus je probeert door dat eigenaarschap laag te leggen, natuurlijk al een soort van hè, dat noaberschap was dan ook wel vaak genoemd wordt, maar dat gevoel te creëren van het is ik, ik ben onderdeel van de club. Zou ik bijna zeggen, dus het voelt niet zozeer als ik ben klant, maar ik ben meer lid. Dat is toch een verschil.

\section{5:13 \ 43 in Transcript $F$}

Laten we zeggen, hè dus ja, het is eigenlijk dat we met mekaar aan het zoeken zijn van hoe kunnen we nou een totaal mobiliteitsconcept maken die aan al die behoeftes voldoet en er zullen ongetwijfeld auto's over de N18 blijven rijden? Dat is ook niet ons doel, hè. Om dat niet meer mogelijk te maken.

\section{6:8 I 45 in Transcript E}

Ehm op zich lopen we nu niet ergens tegenaan, behalve dat daar ontzettend lange doorlooptijden zijn, eh misschien dat het meest lastig is, is die komen nu vaak voor vanuit openbaar vervoer en ook wel een taxi is gewoon een andere wereld die kennen elkaar eigenlijk niet, ze weten dat ze bestaan. Ze kennen elkaar niet en spreken ook die taal niet en ja, soms lijkt het dan heel moeilijk, terwijl het misschien makkelijker is, maar openbaar vervoer en taxi zitten toch net iets anders in mekaar. Als je deze mensen dan uiteindelijk bij elkaar zet blijkt het allemaal niet zo spannend zijn, maar dat is wel een uitdaging om die wereld van elkaar te begrijpen.

\section{6:9 II 49 in Transcript $\mathrm{E}$}

In de achterhoek hebben we een vrij stevig idee wat wij zouden willen. Daar werken we samen als overheden met de vervoerders, maar ook met andere bedrijven binnen de achterhoek ambassadeurs. Nee, dat gaat wel goed, want daar zitten we ook. We proberen ook al die eindjes aan elkaar te knopen. Ook het mobiliteitsportaal is bijna klaar voor de achterhoek. We hebben netmobiel. Wij zijn het gesprek aan het voeren met arriva, maar dat zit allemaal aan elkaar, want de arriva zit ook weer in Netmobiele. We zijn ook wel een handjevol mensen, dus die weten precies van elkaar en zijn op de hoogte dan gaat denk ik wel goed. Ehm voor de Rijksoverheid die is volgens mij niet zo geïnteresseerd wat wij hier aan het doen zijn ehm. Ze hebben natuurlijk MaaS pilots. Ja, wij zijn waarschijnlijk de eerste die het klaar hebben. Daar kunnen we van profiteren, in die zin dat bijvoorbeeld arriva de laatste Maas pilot in Groningen Drenthe heeft gewonnen, die ook gaat over Wmo vervoer. Dus ja, wat zij daar ontwikkelen kan hier gelijk toegepast worden.

\section{6:16 \ 134 in Transcript E}

Welke dingen kun je wel samen doen, want dat maakt het systeem sterke ehm dus, dan heb ik het meer over dingen als een app of platforms of betaalsystemen of wat dan ook. De provincie zit nu ook op de koers van ja, straks hoef

jij voor vraagafhankelijk vervoer geen OV-chipkaart meer te gebruiken. Dat staat dan niet keihard opgeschreven. Ja, dat is eigenlijk raar als je pretendeert het systeem te maken wat aanvult op openbaar vervoer is het van tevoren al OV-chipkaart is niet geldig.

\section{Q Province}

1 Groups:

Organisation

2 Quotations: 
we hebben ook jaarlijks hebben ook het moment met de provincie een officieel moment met de gedeputeerde.

\section{6:16 \134 in Transcript E}

Welke dingen kun je wel samen doen, want dat maakt het systeem sterke ehm dus, dan heb ik het meer over dingen als een app of platforms of betaalsystemen of wat dan ook. De provincie zit nu ook op de koers van ja, straks hoef jij voor vraagafhankelijk vervoer geen OV-chipkaart meer te gebruiken. Dat staat dan niet keihard opgeschreven. Ja, dat is eigenlijk raar als je pretendeert het systeem te maken wat aanvult op openbaar vervoer is het van tevoren al OV-chipkaart is niet geldig.

\section{Q Rolemodels}

1 Groups:

\section{Behaviour}

1 Quotations:

\section{2:45 \ा 52 in Transcript C}

ik denk dat je dan mogelijk ook het moment bereikt waarop mensen MaaS-mobiliteit inderdaad hebben ontdekt. Arriva is een partij die investeert, maar dat zijn heel veel partijen die daarin investeren, ook allemaal met een business case eronder. Als ik heel eerlijk ben, denk ik dat veel mensen daarin nog wel teleurgesteld gaan raken, de eerste jaren in relatie tot de verwachte opbrengsten, omdat je volgens mij toch altijd te positief wordt gedacht. Over die gedrag is aanpassingen. Mensen zitten vast in bepaalde gedragingen. Die zijn er echt niet zomaar uit te krijgen, ook al heb je goede tools en goede middelen, en het OV zelf is daarvan een prima voorbeeld. Dat hebben het net ook al besproken, want ze gaan echt niet zomaar van af. Ik denk dat daar de verwachtingen wel wat overspannen zijn, maar dat je dus inderdaad over 10-15 jaar.lk denk nee, maar over tien 15 jaar kan ik me voorstellen dat mensen wel bereid zijn om die gedrag aanpassing op zichzelf toe te gaan passen en dat men dat gaat ontdekken. En ik geloof ik echt in een sneeuwbaleffect. Niemand doet het, dus ik doe het ook niet totdat je in je omgeving op een gegeven moment mensen ziet die dat doen en die je meenemen samen. Kijk je dit aan, oké, oh, dat is eigenlijk zo makkelijk. Nou, en op een gegeven moment, dan ben je om, want die omgeving heb je voldoende mensen die doen. Dus je hebt bepaalde voorbeeldfunctie is. En dan pak je dat op en ik denk dat we over tien 15 jaar wel ongeveer zo ver zijn dat mensen Maas.

$\otimes$ Rural

1 Groups:

Mobility

26 Quotations:

\section{1:1 1 2 in Transcript D}

Uitdagingen zijn met name in het rurale gebied

\section{$1: 2$ \ 2 in Transcript D}

Dus een groot gebied met dunne OV lijnen

\section{1:12 \ 4 in Transcript D}

En dan geloven in de kracht van de cooperaties van bottom bottom up in plaats van top to bottom, want in in in onze optiek werkt dat niet in een ruraal gebied

\section{1:13 \ 4 in Transcript D}

Dan zie je bedrijven die op een gat inspringen. Ja, ik weet niet hoeveel auto's en fietsen op gooien en waar ook automatisch gebruik van wordt gemaakt, omdat dat gewoon een hele dichte locaties, dichtbevolkte locaties zijn. $\mathrm{Ja}$, dan dan heb je heel veel vraag naar bepaald vervoer. Vervoersmiddelen in de Achterhoek is dat niet, zoals ik al zei, vanwege het uitgestrekt gebied, dunne lijnen en grote afstanden. Ja, dat maakt het lastig

\section{2:33 \ 28 in Transcript C}

Dus ik denk dat het daar vooral zit in eigenlijk het omgekeerde, is de kracht om daar te kunnen komen bij die hub? Eh lijnen worden gestrekt. Zeg maar dus dat lijnennet, dat wordt steeds rechter of zo, maar steeds grotere afstanden tot de lijn nemen dus toe of halte van de lijn nemen toe. En ja, dat maakt dat mensen op gegeven moment steeds vaker. Ik pak vaak gewoon de auto, want dan moet ik bijna een kilometer lopen, zeg maar weet je wel en dat kost ook gewoon tijd, hè, je loopt zo een kwartier. Nou, en dan ben je ook niet blij, maar wij hebben alle bekende nadelen van het OV, die hoef hoeft niet te vertellen. Dus dat mensen dus, als je die hub op verschillende manieren kunt benaderd, bijvoorbeeld met een busje wat je ophaalt en je daar trapt of met een elektrische deelfiets 
die die op de hoek van de straat staat: zo'n carrousel met ons iets ofzo. Ja, dan pak ik daar die fiets. Dan fiets ik snel naar die hub. En dan pak ik daar vervolgens dingen dus ik denk dat daar in het landelijk gebied vooral de aandacht moet zijn die hub. Je moet natuurlijk een beetje goed smoelen, maar hoe is die hub bereikbaar anders dan wordt het gewoon een mooi stuk aangelegd stuk grond in een weiland waar een mooie parkeerplaats is voor de regiotaxi, waar deel fietsen staan, die niemand gebruikt en een mooi informatiezuil en de bus die aan twee kanten wegrijdt. Maar wie komen daar dan? En Hoe?

\section{3:9 Iा 30 in Transcript B}

Volgens mij wordt gewoon gekeken naar het benutten van technologische mogelijkheden en een nieuwe innovaties, en dat dat beter zou zijn, of dat wat we nu hebben anders in stand zou kunnen blijven. Daar hoor ik niemand over, dus of dat heel expliciet überhaupt een rol speelt, dat weet ik eerlijk gezegd niet.

\section{3:11 Iा 34 in Transcript B}

Misschien ook wel één van de meest opmerkelijke uitkomsten is dat mensen hier zo dicht bij hun werk wonen. Dus dat betekent - en dat zie je ook op een industrieterrein, heel veel mensen op de fiets of met de auto omdat ze gewoon autorijden leuk vinden of niet. Daar waar het veronderstelde probleem zit dat is bij nieuwe medewerkers, ook jonge medewerkers, hoe krijg je die nou op de werkplek? En hoe gaan mensen ook zien dat werkplekken ergens op een industrieterrein in Steenderen of Hengelo of Ulft of zo, dat dat ook een optie is als je in Arnhem zit en dan kom je daar daardoor. Als je dan een auto hebt, dan is ook best wel weer een afstand en tijd hebben. Ook kan je natuurlijk met het OV, maar heel veel werk locaties zijn helemaal niet bereikbaar met het OV. Zo kan je ook vragen aan ondernemers: wat denken jullie dat kansrijk is? Kun je ook samenwerken als bedrijf om iets van een pendeldienst ofzo te laten draaien? Het OV systeem is daar vrij slecht op ingericht.

\section{3:14 \ 40 in Transcript B}

ijk als je, als je dat bedoeld vanuit je kunt alleen maar bedrijven bij OV knooppunten plaatsen. Ja, dat kan. Het netwerk in de Achterhoek vinden wij alleen te onduidelijk en te vaag en ongestructureerd, dus dat kan never nooit die structurerende werking hebben, kansloos. Wel zijn er wat kansen onbenut op stationslocaties.

\section{3:17 I 46 in Transcript B}

. We hebben hier in de Achterhoek gewoon iets anders. De achterhoek monitor laat dan zien dat mensen dus heel wonen heel dicht bij hun werk wonen. Ja, ja, op papier. Als dat bedrijf gevestigd is op het industrieterrein Hengelo je woont in Hengelo, dan kun je net op de fiets naar je werk. Maar als je vervolgens met een busje van dat bedrijf jouw werkzaamheden daadwerkelijk uitvoert, omdat je installatie technicus bent, ja, dan is het toch weer een ander verhaal. Een ander verhaal is dan die mobiliteit. Als je om vijf uur opstaat om om half zeven in Amsterdam aan de slag te kunnen, nou, dan heb je dus toch wel die afstand naar Amsterdam gereden en er zijn best veel mensen die het doen. Dus het lijkt heel kort bij, want het is natuurlijk ook niet. Kijk uit inderdaad met die aannames.

\section{3:27 II 91 in Transcript B}

Dat is heel cruciaal, dus de grootste mobiliteitsproblemen die wij hebben en voor de ontwikkeling van mobiliteit in onze regio. Met daarop aansluitend kunnen wij aansluiten met de bus. Dat zou enorm helpen. De spoorverdubbeling Arnhem Winterswijk, ja, dat zou dat is zo belangrijk, anders kun je bijna niks, als je dat niet voor elkaar krijgt, dat wordt onderschat. Hetzelfde geldt voor de belangrijke spoorverbinding voor de westelijke helft van de Achterhoek, het spoor Zwolle Roosendaal en hoe haken we daaraan? Hoe krijgen we dat nou goed voor elkaar, dus op Zutphen en dieren? Dat is heel belangrijk en is een knetter drukke spoorlijn. Als je daar 's morgens naar de trein stapt, dan kun je aansluiten op het balkon en staan.

\section{4:5 शा 16 in Transcript A}

Kijk uiteindelijk heeft Gelderland inderdaad in de visie: mobiliteit hubs, die pakken wij als regio op. Dus daarom is netmobiel een project voor ons in het hele aanbod zou ik eigenlijk willen zeggen dus mobiliteit hubs, ja, daar zijn we nu al mee bezig. We gaan een inventarisatie doen nu ook van waar willen we? Welke hubs? Wat zien we ook als kans daarin hè in die gradatie die Gelderland daarin gemaakt heeft? Rurale hubs, regionale hubs, enzovoorts en welke voorzieningen willen we daar dan?

\section{4:9 1 39 in Transcript A}

Dus je probeert door dat eigenaarschap laag te leggen, natuurlijk al een soort van hè, dat noaberschap was dan ook wel vaak genoemd wordt, maar dat gevoel te creëren van het is ik, ik ben onderdeel van de club. Zou ik bijna zeggen, dus het voelt niet zozeer als ik ben klant, maar ik ben meer lid. Dat is toch een verschil. 


\section{4:11 П 42 in Transcript A}

Ik bedoel begrijp me goed, ik snap dat de meeste mensen toch daar wonen, maar tegelijk, dat zie je ook wel, dat ze ook begrijpen dat de bereikbaarheid in de plekken waar wij wonen, zeg maar ook nog steeds heel belangrijk zijn. Alleen ze weten niet hoe ze dat moeten oplossen. lk zeg het gewoon letterlijk, zoals het is omdat er ook geen oplossing voor is. Kijk stedelijk, waar heel veel wordt georganiseerd en wereldwijd wordt heel veel georganiseerd 4:13 \ा 44 in Transcript A

Wij moeten ook niet denken dat we hetzelfde willen als wat er in Arnhem gebeurt hè.

5:1 $\mathbb{1} 13$ in Transcript $F$

De Achterhoek heeft een gebiedsopgave, hè, en die opgave is erop gericht dat in zeg maar het landelijke gebied eh wordt voorkomen dat de bevolking krimpt, vergrijst en dat soort zaken dus, het moet prettig wonen en werken blijven in de Achterhoek, hè en één van de voorwaarden om dat te realiseren is eh het bereikbaar zijn van werklocaties en regionale voorzieningen waar de Achterhoekers gebruik van maken.

\section{5:5 I 21 in Transcript F}

Daarom doe je slimme mobiliteit bijvoorbeeld en in die landelijke regio 's als de Achterhoek gaat het meer om het Netmobiel houden en bereikbaar houden van voorzieningen wat je hebt in de Achterhoek geen file knelpunten bij wijze van spreken, hè. De trein zit aardig vol, zat aardig vol, zou je kunnen zeggen, dus dat is wel een dingetje, maar daarom de Achterhoek ook niet als het bijvoorbeeld gaat om de spoorlijn. Zij mikken niet op eh, meer capaciteit en het oplossen van capaciteit, knelpunten op wegennet en spoorlijnen, maar zij mikken op sneller in Arnhem en vervolgens verder richting Randstad te kunnen zijn, omdat daar de werklocaties dus zijn. Zij gaan veel meer uit van het criterium van nabijheid. Eh laat maar zeggen, hè de nabijheid principe van vanuit de Achterhoek van hoe nabij zijn nou baan en voorzieningen en dat soort zaken.

\section{5:6 \ 23 in Transcript $F$}

Alleen dat de uitwerking van wat gaan we dan doen met mekaar in zo'n landelijke regio's? Die is wat anders als in stedelijke regio 's, hè dus enerzijds is ie nog steeds gericht op zeg maar het verbeteren van eh of het versnellen van verbindingen, hè, zowel over de weg als met de fiets. Hè, want dat kun je ook. Dus de doelstelling in de Achterhoek is versnellen van ov-verbindingen en niet het ja, het laten rijden van meer treinen en dat soort dat soort zaken. En dan komt jouw vraag met de hubs. Hubs is volgens mij en volgens de Achterhoek een belangrijk onderdeel in hun aanpak. Slimme mobiliteit, oftewel mobility as a service, eh en de Achterhoek heeft de ambitie om aan te sluiten aan de zeven of acht landelijke Maas pilots. Ze willen de achtste landelijke Maas pilot doen, en dat is eigenlijk: hoe krijg je nou mobility as a service, goed georganiseerd in niet stedelijke regio's en daar zijn ze best wel aardige stappen aan het over aan het maken en daar kan ja kan ik je ook best wel eh wat meer informatie over geven, maar zeker interessant om dan bijvoorbeeld nog een keer zo'n gesprek te doen met JT.

\section{5:8 I 31 in Transcript $F$}

us naar één de gedragsbeïnvloeding kant. Dat is voor ons gewoon echt nog echt een onbekend terrein. Wat wij ook gewoon nog moeten verkennen, hè. Hoe stimuleer je de reiziger dan om op de juiste manier te gaan reizen. Als wij dat als een oplossing zien. Ja, dan moeten ze er wel gebruik van gaan maken en er zijn voorbeelden in het land. Neem even in Groningen, bijvoorbeeld waar die hubs worden neergezet. Ah, joh, die zit er helemaal gelikt uit, maar niemand die er komt. Dat is dan net op de verkeerde locatie. Ja is van tevoren onvoldoende onderzoek gedaan, en dat dat de juiste plek is. Daarvoor is dus gedragsbeïnvloeding zo belangrijke. Ja, dat is wel belangrijk voor de Achterhoek.

\section{5:9 Iा 31 in Transcript $F$}

Het OV vermijden - en dat is voor ons als opdrachtgever van het openbaar vervoer echt ja een hoofdpijndossier, momenteel hè. Van hoe hou je het openbaar vervoer levend? Hoe zorg je dat de vervoerders nog in gaan schrijven en nog met openbaar vervoer überhaupt gaan rijden? Maar ook op langere termijn verwachten we juist dat de Achterhoek wat meer vol gaat lopen en dat mensen meer thuis gaan werken, dus dat bedrijven, maar ook mensen uit de Randstad, dit een aantrekkelijk gebied gaan vinden

\section{5:10 ๆ 35 in Transcript $F$}

leefbaarheid in dat gebied. Ik denk dat de kans ligt om, als je het op een andere manier organiseert, dat je de gebied beter bereikbaar kan maken en daar dus ook ten gunste van de leefbaarheid. Dat schrijven we ook in de visie, hè. Het is niet meer dat de bereikbaarheid van een gebied het doel is. Nee, we gaan kijken wat de leefbaarheid 
van dat gebied vergroot, de aantrekkelijkheid voor wonen, bedrijf om zich gaan vestigen en daar ligt nu wel momenteel een mooie kans om dat op een andere manier te organiseren.

\section{5:11 939 in Transcript $F$}

We hebben wel vaker geprobeerd hè om mobiliteit aanpakken. In regio's projecten op te pakken, hè, met mobiliteitsmakelaars en zo, dat is ook niet een heel nieuw woord. In het verleden hadden wij dan vaak geld en dan gingen we aan de slag. En als het geld op was, dan zakte dat weer in mekaar en er liggen nu kansen om dat eh in de samenwerking met de Achterhoek, om dat niet te laten gebeuren. Dus om ook iets blijvends te maken. Er ligt ook nu een kans in de Achterhoek om dat met alle regionale partners te doen, dus niet alleen met de gemeente, hè, maar ook met ondernemers, met organisaties als het nieuwe slingeland ziekenhuis en dat soort zaken, hè. De Achterhoek is nu georganiseerd op die drie hè, overheid, ondernemers en organisaties, en die werken daar ook steeds meer samen in samen. En volgens mij is dat ja de grote kans die er nu ligt in de Achterhoek om het nu echt iets blijvends te maken. Een stap verder te brengen, want als je het trekt puur vanuit de overheid, dan blijft het vaak een beetje in die voorbeeldprojecten en die pilot hangen.

\section{5:20 \} 6 2 \text { in Transcript } F}

Dus we moeten ook meedenken met wat fijnmazig netwerk aan hubs en dat soort zaken

\section{6:4 ๆ 21 in Transcript E}

$\mathrm{Ja}$, dat hangt een beetje van af, want als de provincie toch denken aan een systeemwijziging, hoeveel zin heeft het dan nog, want dan weet je wat we nu hebben. lk had het graag uitgevoerd.

\section{6:5 ๆ 33 in Transcript E}

De kans dat je dat je in het landelijk gebied de twee mensen hebt die op dezelfde moment naar dezelfde moeten is toch nul. Ja.

\section{6:10 \ 64 in Transcript $\mathrm{E}$}

Ehm, want dat kan toch niet zo zijn dat iemand in Duitsland vervoerd wordt voor de kosten van de provincie Gelderland was het verhaal, dat is iemand die zelfs in een thuis kan bij ons gewoon rit boeken. En dat is die van Winterswijk, want dat kan de provincie in Arnhem niet begrijpen en dat ik zeg: ja, maar iemand die uit Enschede komt, en dat willen wij graag. Mag dat wel, dan wil ik mag zijn. Wat is nou het verschil tussen iemand uit Enschede of Duitsland? Dus dat ze wel willen, maar niet snappen hoe het echt in elkaar zit. Die grens bestaat natuurlijk eigenlijk niet. Nee, zo op deze kleine schaal voorzie je wel in een behoefte. Het is een hele kleine behoefte. Ongeveer 1000 ritten naar Duitsland op de 250000, maar juist het aandeel binnen die ik die niet Wmo is, is relatief groot, dus daar is wel de behoefte ehm. We mogen alleen niet in Duitsland vervoeren, hè dus je mag naar Duitsland, je mag van Duitsland hierheen, maar binnen Duitsland mogen wij niet vervoeren. lk weet wel dat een kreis Borken, wel eens gevraagd heeft van, hoe doe je eigenlijk het vervoer, dan zouden we daar wat van kunnen leren, dus dat is op zich wel interessant. Ja, de spanning is natuurlijk niet zo hoog, dus in het grensgebied.

\section{6:11 102 in Transcript $\mathrm{E}$}

Je moet een vervoerssystemen neerzetten in de achterhoek waar iedereen mee kan rijden, inclusief vervoerssysteem waar jij en ik ook gebruik van kunnen maken waar mensen die in een plek wonen waar geen bus komt, dat die ook gewoon op dezelfde manier kunnen reizen.

$\otimes$ Shared

1 Groups:

Mobility

14 Quotations:

1:9 \ 2 in Transcript D

kracht ligt op deelvervoer,

1:10 12 in Transcript $D$

verschillende stations en enkele toeristische locaties $\mathrm{i}$

\section{1:21 If 8 in Transcript D}

En dan hoeft niet per se met een deelauto te zijn die in het bezit is van meerdere mensen, maar dat zou ik bijvoorbeeld ook in het rit delen kunnen zetten. Dus het delen van ritten

\section{1:24 \ा 13 in Transcript D}

Dat vraagt ook gewoon echt om campagnes en in die campagnes willen wij ook echt duidelijk maken dat bijvoorbeeld 110 
een deelauto die wij nou in de kern hebben staan.

\section{1:25 \ा 13 in Transcript D}

Daar hangt een bepaald tarief aan vast en het tarief dat is gebaseerd op een gewoon gezin, gewoon Nederlands gezin die de kinderen zoveel dagen per week weg moeten brengen, die boodschappen moeten doen en aan onderaan de streep aan het einde van de maand voordeliger uit is met de hoeveelheid uren die ze maken met een auto, gebruik van de deal, auto dan een eigen auto aanschaffen en die moeten onderhouden, daar hebben we die berekeningen op gebaseerd en ehm ja dus op op die manier om dat duidelijk te maken.

\section{1:38 \ा 27 in Transcript D}

Nee, wij willen echt dat die gebruikt gaat worden. Dus wij hadden vooraf ook echt als eis gesteld. Wij willen wel aan de voorzijde, dat jullie net als wij risico delend inzitten, dus ervoor te zorgen dat de krachten gebundeld zijn. Je zet risico delend in. Oké, jullie moeten aan de voorkant zoveel abonnementen of prepaid, goede ET cetera, verkopen om dan quitte te draaien. Nou, dat is volgens ons heel goed model, krachtig inzetten, maar we willen wel die stok achter de deur hebben dat die ook blijft.

\section{1:39 \ 31 in Transcript D}

Ze worden goed gebruikt, maar ze hadden nog veel beter gebruikt kunnen worden, maar in ieder geval. Wij hadden inderdaad te verwachten dat we dat sowieso al verder konden uitrollen de komende jaren. Misschien moeten we die verwachting iet wat bijstellen, maar er is wel heel veel animo voor, dus er zijn heel veel ondernemingen, ook bij toeristische attracties, bijvoorbeeld die zoiets hebben van hé: 'Dit is een leuk concept, kunnen wij daar ook iets mee? Kunnen wij daar ook risicodeling inzitten om ervoor te zorgen dat die fietsen hier staan?' Dus ja, die animo, die is er zeker en dan merk je ook steeds meer en daar zijn we ook actief mee bezig. Om dat verder uit te rollen.

\section{1:40 ๆ 37 in Transcript D}

Je kunt je auto's niet parkeren en je bent misschien slecht ter been. Ja, je hebt geen, je hebt geen alternatief op dat moment, want het is nog niet op zo'n grote schaal uitgevoerd. Die deal is dat mensen die deel auto ook echt kunnen laten staan

\section{1:42 \ 45 in Transcript D}

netmobiel, het wordt ontwikkeld, maar zo'n app, bijvoorbeeld, heel simpel, stel je bent slecht te been. Je kunt via de app straks ook gewoon een rit aanvragen: en dan zou je kunnen zeggen van ik moet van hier naar hier en ik moet wel weer terug. Dan zou je dat kunnen zien en sowieso rit gewoon kunnen accepteren. Met die app zou je dan ook voor punten kunnen sparen. Krediet als het ware, is geen gewoon geld, maar krediet kun je aan een goed doel geeft, maar kun je inderdaad ook uiteindelijk voor gebruiken om erin te gebruiken.

\section{1:44 \ा 47 in Transcript D}

We hebben ook ZOOV die zich inzet voor Wmo voor doelgroepenvervoer die nu dus ook al bepaalde ritten voor arriva oppakt. Als het nodig is, dan hoeft er geen hele bus te rijden, maar dan kan er een busje van gaan rijden, en dat willen we eigenlijk. Het liefst verder uitrollen, zodat zon grote bus zo 's avonds niet per se beschikbaar moet zijn en moet rondrijden puur en alleen omdat we die lijn in stand moeten houden. Nee, dat zou bijvoorbeeld ook op afvraag kunnen zijn, op oproep kunnen zijn. Daar zijn we ook mee bezig. Proberen we ook goed vorm te geven, want het is gewoon zonde om geld weg te gooien, terwijl dat elders misschien heel goed met elkaar kunt combineren en dan kunt besparen en weer op een andere manier deelvervoer bijvoorbeeld, kunt inzetten

\section{3:23 \ा 62 in Transcript B}

Kijk dus elke vorm van individueel vervoer wint natuurlijk snel van collectief vervoer. Andere interessante vervoersvormen voor individueel vervoer zijn interessant. De elektrische fiets, speed pedelec en allerlei andere tussenvormen die natuurlijk gaan komen die niet in onze categorieën passen, maar die zijn wel interessant, vooral omdat ze veel lichter van gewicht zijn. Die auto is natuurlijk loodzwaar. Zeker elektrische auto's. Nou, dat is nogal wat. Het moet allemaal verplaatst worden.

\section{4:8 \ 31 in Transcript A}

We hebben nu bijvoorbeeld de eerste elektrische deelauto's die in Groenlo komt te staan, drie elektrische deelauto's. Daar hebben wij de energiecoöperatie Groenlo die doet mee. Dus die is, zeg maar even de vragende partij geweest, dus die betalen die auto's. We hebben de leverancier van de auto, dat is een dealer die gewoon de auto levert, die doet hè, die doet ook risico mee voor een stukje. We hebben natuurlijk de eerste klanten die zich hadden aangemeld die door risicodragend mee de launching customers, zoals we die zo mooi noemen. Ja en de rest financieren wij 
vanuit de overheid, alleen hoe doen we dat dan? Nou, dat gaan we dus doen via de coöperatie. Dus wat we aan het doen zijn is een hele coöperatie opzetten: overheid, ondernemers, energiecoöperaties, maatschappelijke instellingen, dus bijvoorbeeld de ziekenhuizen, de hogeschool of de ROC. Die kunnen allen participeren in die coöperatie, en daarmee hebben we dat dus ontwikkeld. We hebben het dus met elkaar. Ook de kosten kunnen delen, waardoor we dus ook een bestendig duurzaam model kunnen neerzetten. Want als we hadden gezegd van nou, weet u, we doen alleen maar wat geld voor die auto in Groenlo dat we één ding zeker de kans dat die auto's over vier jaar als de subsidie afgelopen is en dan nog rijden. Nou, dat is daar bijna een gelukje. Zou bijna zeggen doordat we er in de coöperatie mee bezig zijn, kunnen we ook gewoon na die vier jaar prima nog wat geld eventueel daarvoor besteden als dat nodig is, omdat we ook weten dat het daarmee iets in stand te houden. Maar dat betekent ook dat er aan de andere kant geld van andere partijen wel bij moet. Ik bedoel: wij gaan als overheid niet ondernemen, maar dat kan best wel zijn dat deze actie in Groenlo dadelijk wel geld oplevert. Die auto's. Dus daar is geen geld bij nodig, maar daar wordt geld verdiend, maar dat misschien in een ander dorp de auto wel nog wat geld nodig heeft. Maar dat is waar we dat coöperatief doen, omdat je dan met elkaar de lusten en lasten deelt. 4:9 \ 39 in Transcript A

Dus je probeert door dat eigenaarschap laag te leggen, natuurlijk al een soort van hè, dat noaberschap was dan ook wel vaak genoemd wordt, maar dat gevoel te creëren van het is ik, ik ben onderdeel van de club. Zou ik bijna zeggen, dus het voelt niet zozeer als ik ben klant, maar ik ben meer lid. Dat is toch een verschil.

\section{4:10 \} 4 0 \text { in Transcript A }}

We hebben goede auto's, hebben een goed systeem gekozen die auto's opent, boekt en noem alles, maar ook de tarieven moeten gewoon kloppen, hè. We moeten ook aantrekkelijk zijn, maar ook niet gratis hè. Daar zit echt wel in verschil in. Dus ja, het product moet gewoon kloppen. Ik denk dat dat het allerbelangrijkste is, want dan gaan mensen het ook wel begrijpen. En dan gaan mensen het ook wel gebruiken.

$\otimes$ Subsidy

1 Groups:

Organisation

3 Quotations:

\section{1:45 \ा 49 in Transcript D}

Middels die regio deal van de Rijksoverheid, hebben we heel veel zaken in stand kunnen zetten. We heel veel zaken kunnen oppakken, is heel veel projecten die worden bekostigd. lk heb er eventueel nog wel wat linkjes, maar ik denk dat je er zelf ook al wel hebt gezien, die ik jou kan sturen. Dankzij de Rijksoverheid en een bijdrage leveren in de regio deal is dit mogelijk.

\section{2:4 \ा 4 in Transcript $C$}

at is een belangrijke, die infrastructuur die wordt over het algemeen niet aangelegd door de vervoerder die wordt aangelegd door gemeente, provincie, energiemaatschappijen. Dus dat maakt wel weer een soort ja noodzakelijk vorm van samenwerking, maar ook van investering.

\section{3:22 \ 60 in Transcript B}

Ze hoeven niet uit de auto, dus dat is een belangrijk uitgangspunt. Dit wordt vooral door Europees beleid en landelijk beleid veroorzaakt. Subsidiestroom dus

$\otimes$ Sustainable transportation

1 Groups:

Infrastructure

30 Quotations:

1:5 ๆ 2 in Transcript D

De Achterhoekers zijn echte autorijders en om dat zo duurzaam mogelijk te maken...

1:14 96 in Transcript D

energie neutraal

\section{1:17 \ 6 in Transcript D}

Ook hebben we een hoop mobiliteitmakelaars in de Achterhoek lopen die ook bij bedrijven langsgaan om hen te helpen met het energievraagstuk en met de duurzaamheidsvraagstukken van kunnen jullie binnen je bedrijf misschien wel verbeteren 


\section{1:21 I/ 8 in Transcript D}

En dan hoeft niet per se met een deelauto te zijn die in het bezit is van meerdere mensen, maar dat zou ik bijvoorbeeld ook in het rit delen kunnen zetten. Dus het delen van ritten

\section{1:44 \ा 47 in Transcript D}

We hebben ook ZOOV die zich inzet voor Wmo voor doelgroepenvervoer die nu dus ook al bepaalde ritten voor arriva oppakt. Als het nodig is, dan hoeft er geen hele bus te rijden, maar dan kan er een busje van gaan rijden, en dat willen we eigenlijk. Het liefst verder uitrollen, zodat zon grote bus zo 's avonds niet per se beschikbaar moet zijn en moet rondrijden puur en alleen omdat we die lijn in stand moeten houden. Nee, dat zou bijvoorbeeld ook op afvraag kunnen zijn, op oproep kunnen zijn. Daar zijn we ook mee bezig. Proberen we ook goed vorm te geven, want het is gewoon zonde om geld weg te gooien, terwijl dat elders misschien heel goed met elkaar kunt combineren en dan kunt besparen en weer op een andere manier deelvervoer bijvoorbeeld, kunt inzetten

\section{2:8 96 in Transcript C}

Het kan niet voor hetzelfde bedrag, maar dan groen. Er moet dan, gewoon de prijs van vergroening worden betaald. Die moet op enig moment bepaald worden tot alles vergoed $\mathrm{i}$

\section{2:9 96 in Transcript $C$}

Het eerste is gewoon de investering in nieuw materieel. Twee is dat je van dat nieuwe materieel, wat veel duurder is, ook nog veel meer nodig hebt.. Daarnaast heb je natuurlijk nog andere vormen van duurzame mobiliteit in mijn beleving. Of een op diesel draaiende auto met één persoon erin van a naar $b$ rijdt of in plaats daarvan met twee personen van a en b. Dat is ook een vorm van duurzaam in mijn beleving eh duurzaam is wat mij betreft ook demand responsive transport.

\section{2:14 If 8 in Transcript C}

ie vraagt ook een stukje flexibiliteit van de gebruiker. Die moet daar ook een beetje mee om kunnen gaan versus die zekerheid van nou ja, is daar kwart over gaan staan dan komt vier vijf minuten later komt de bus. Mocht het een keer tegenvallen is die tien minuten later, maar hij komt wel heel vaak, negen van de tien keer ja, en dat is toch een hele andere manier van reizen, en ik denk dat die eigenlijk iedereen in de branche die gelooft waarin alle opdrachtgever, alle mensen die er omheen zitten, of het nou Moventem is of een universiteit. Die geloven daar wel in.

\section{2:25 \ा 14 in Transcript C}

Als je het 100 mensen gaat vragen krijg je 100 verschillende antwoorden, daar zit ik niet op te wachten

\section{2:42 \ा 46 in Transcript C}

Dat wordt veel te lastig en dan komt een waterstof bus in beeld, omdat die een grotere actieradius hebben en die qua gebruik veel dichter bij de operationele gebruikt veel dichter bij een diesel bus. Je denkt dat vol tien minuten, net als mijn bus en dan rijdt ie 400 kilometer voordat ie weer aan de aan de pomp komt. Net als deze op is is het beste kan verder, maar hij komt qua gebruik, is gevoelsmatig gewoon een diesel bus, maar dan wel met een die die die veel zuipt, om het zo maar te zeggen met een wat kortere actieradius. En dat is de reden van met name in het streekvervoer wordt er heel erg gekeken naar waterstofbussen en eh. Tegelijkertijd weet je dat batterij ook steeds grotere actieradius krijgen. Steeds lichter, steeds meer vermogen hebben voor kleinere batterijen. Dus wij hebben bij altijd ook gezien de eerste je 150 kilometer rijden. Nu haal je 500 à 600 dus daar zal ongetwijfeld ook weer een stap in worden gemaakt. En het is een beetje de vraag. Maar als je op dit moment in de streek zou moeten rijden met batterij bussen, dan heb je wel een serieus probleem en daar komen we dus die waterstof dus van nou. 2:43 शा 48 in Transcript C

Nou ik denk dat je nooit helemaal zeker als techniek en een beetje in de ontwikkelingsfase zijn, je blind moet staren op één techniek. Ik denk dat je dat gewoon niet kunt. Voorlopig gebruiken wij waterstof en zie je wel heel duidelijk dat er twee kampen zijn, bijna hè, batterijen, elektrisch tegen waterstof en andersom

\section{2:44 शा 48 in Transcript C}

We hebben best wel wat batterij bussen rondrijden, maar van die andere weten we eigenlijk gewoon helemaal niks en is het dus gewoon zaken om daar kennis van op te doen. De mogelijkheid dat je daar over tien jaar zegt: nou ja die hebben we een tijdje gehad.

\section{3:1 92 in Transcript B}

afhankelijk van de ontwikkeling van voertuigen, met name ook wel elektrisch aangedreven voertuigen 


\section{3:2 \ 2 in Transcript B}

Ikzelf denk dat de grootste uitdaging is om goed in beeld te hebben, te houden, wat zijn de grootste vervoersgroepen waar je ook vormen van openbaar vervoer of vraag gestuurd vervoer maar collectief geregeld kan toepassen?

\section{3:3 \ा 4 in Transcript B}

, want het is niet per se publiek maar kan ook privaat georganiseerd worden, maar de stromende corridor, de route waar bundeling van personenvervoer althans mogelijk is. Ja, dat zou je zou kunnen zeggen nu de belangrijkste spoorverbindingen en de grootste buslijnen. Volgens mij zijn daar nog een paar stappen in te zetten: het strekken van buslijnen, het creëren van een logistiek netwerk.

\section{3:5 \ 20 in Transcript B}

En of dat allemaal duurzaam is, dan moet je je afvragen. Kijk, je kan iedereen opjagen, met elektrische auto's, maar ik weet eerlijk gezegd niet of dat nou echt duurzaam is

\section{3:6 श 20 in Transcript B}

Het gaat vooral om nieuwe mogelijkheden om mobiliteit te organiseren of aanbod en vraag van mobiliteit bij elkaar te brengen, en ik denk dat daar de focus eerlijk gezegd op ligt. Of we dat nou goed doen voor de auto, een belangrijk vervoersmiddel, evengoed als de fiets, of voor de speed pedelec - daar kun je ook grote afstanden mee overbruggen. Dus daar zit vooral veel technologische ontwikkeling in mobiliteit en een belangrijk deel van de aandacht gaat uit naar hoe benutten we die nieuwe vormen van technologie.

\section{3:18 If 48 in Transcript B}

drie vier belangrijkste vervoersmotieven en zoek naar de kansrijke onderdelen van het verplaatsen en probeer daar nieuwe vervoersconcepten of mobiliteitsaanpak in te ontwikkelen. En moet dat dan duurzaam zijn of niet? Ja, dat ligt er naar het vertrekpunt van je beleid, dat is een keuze dat kan. Maar ja, er is natuurlijk niks op tegen, dus ik wil daar niks van af doen. Dat is een belangrijk beleidsmotief: je moet je wel realiseren dat als je wil aansluiten bij de leefwereld van de reiziger dat dat niet per se hoeft te betekenen dat die reiziger ook heel graag een duurzaam mobiliteitsalternatief wil.

\section{3:23 Tा 62 in Transcript B}

Kijk dus elke vorm van individueel vervoer wint natuurlijk snel van collectief vervoer. Andere interessante vervoersvormen voor individueel vervoer zijn interessant. De elektrische fiets, speed pedelec en allerlei andere tussenvormen die natuurlijk gaan komen die niet in onze categorieën passen, maar die zijn wel interessant, vooral omdat ze veel lichter van gewicht zijn. Die auto is natuurlijk loodzwaar. Zeker elektrische auto's. Nou, dat is nogal wat. Het moet allemaal verplaatst worden.

\section{4:1 1 2 in Transcript A}

Dus dat bedrijven, dus werkgevers bijvoorbeeld, en uiteindelijk natuurlijk de mensen die zelf reizen naar hun werk, dat ze zich veel meer bewust zijn van hè. Als ik de autopark is dat minder duurzaam dan de fiets kijk, we zijn er achter, ook heel erg gewend om van onze eigen vervoersmiddelen gebruik te maken. Fietsen, een auto op motor, maar je ziet ook wel dat de stap naar de verduurzaming daarin.

\section{4:6 I 20 in Transcript A}

wij geloven er niet in dat je van bovenaf kan bepalen waar je wat neerzet. Dit is in steden natuurlijk met heel anders met aanbieders. Ja, die zet er ergens wat neer, omdat ze denken vanuit allerlei analyse met data dat daar vraag is. Even cru, maar dat is een beetje hoe het gebeurd. In de achterhoek gaan we het anders aanpakken. Wij geloven heel erg van de kracht van onderop, dus dat wil zeggen dat wij echt wachten en natuurlijk stimuleren. Dat hè, maar ik zeg dan maar eventjes wachten totdat van onderop de vraag komt: hè, wij willen iets met een deelauto deelfiets $\mathrm{mmm}$ dus toen die challenge werd neergezet door meneer Bouwmans was dat heel mooi. Toen waren we ondertussen al een beetje bezig met de deelfiets. Dus dat scheelt met de toeristische sector, alleen, wat merk je dan? Kijk een aanbieder van fietsen, Urbee in dit geval of arriva die als partner meedoet, dat die hebben een hele andere filosofie, visie, denkwijze, de andere business dan dat je aan de vraagkant, dus waar we op zaten, te wachten. Aan de vraagkant zal bijvoorbeeld toeristische sector zeggen: ja, we willen gewoon fietsen kunnen verhuren. Arriva zegt wij willen onze bus goed kunnen vullen en u zegt: ik wil mijn fietsen zoveel mogelijk kunnen inzetten. Dus waar zit de grootste uitdaging? De verschillende businessmodellen? Misschien kun je dat soort best omschrijven van de partijen en je bij elkaar proberen te brengen om dat op één lijn te krijgen. Dan zeggen uitdaging. Het makkelijkste was Urbee bellen.

114 


\section{4:8 I 31 in Transcript A}

We hebben nu bijvoorbeeld de eerste elektrische deelauto's die in Groenlo komt te staan, drie elektrische deelauto's. Daar hebben wij de energiecoöperatie Groenlo die doet mee. Dus die is, zeg maar even de vragende partij geweest, dus die betalen die auto's. We hebben de leverancier van de auto, dat is een dealer die gewoon de auto levert, die doet hè, die doet ook risico mee voor een stukje. We hebben natuurlijk de eerste klanten die zich hadden aangemeld die door risicodragend mee de launching customers, zoals we die zo mooi noemen. Ja en de rest financieren wij vanuit de overheid, alleen hoe doen we dat dan? Nou, dat gaan we dus doen via de coöperatie. Dus wat we aan het doen zijn is een hele coöperatie opzetten: overheid, ondernemers, energiecoöperaties, maatschappelijke instellingen, dus bijvoorbeeld de ziekenhuizen, de hogeschool of de ROC. Die kunnen allen participeren in die coöperatie, en daarmee hebben we dat dus ontwikkeld. We hebben het dus met elkaar. Ook de kosten kunnen delen, waardoor we dus ook een bestendig duurzaam model kunnen neerzetten. Want als we hadden gezegd van nou, weet $u$, we doen alleen maar wat geld voor die auto in Groenlo dat we één ding zeker de kans dat die auto's over vier jaar als de subsidie afgelopen is en dan nog rijden. Nou, dat is daar bijna een gelukje. Zou bijna zeggen doordat we er in de coöperatie mee bezig zijn, kunnen we ook gewoon na die vier jaar prima nog wat geld eventueel daarvoor besteden als dat nodig is, omdat we ook weten dat het daarmee iets in stand te houden. Maar dat betekent ook dat er aan de andere kant geld van andere partijen wel bij moet. Ik bedoel: wij gaan als overheid niet ondernemen, maar dat kan best wel zijn dat deze actie in Groenlo dadelijk wel geld oplevert. Die auto's. Dus daar is geen geld bij nodig, maar daar wordt geld verdiend, maar dat misschien in een ander dorp de auto wel nog wat geld nodig heeft. Maar dat is waar we dat coöperatief doen, omdat je dan met elkaar de lusten en lasten deelt. 4:12 \ 42 in Transcript A

Want het grote probleem is daar natuurlijk dat het aanbod er wel kan zijn, maar dat de vraag dan misschien niet is. Dus hoe ga je daar nou te werk in die discrepantie tussen die twee, hoe ga je dat nou oplossen? Wij hebben dus ook daar ons verhaal verteld hoe we dat coöperatief willen doen van onderop. Dat gaat langer duren. Je hebt het niet in één keer en nu hebben 100 fietsen, maar je hebt niet in één keer 1000 fietsen staan in een jaar dat gaat dan gaat gewoon niet gebeuren. Dit kan best wel eens de manier zijn waarop dat georganiseerd kan worden. Dus dat wordt heel positief ontvangen. Budget is vaak dan nog wel een ding, maar we willen support geven en daarmee een stuk vrijheid en dan is het mooi dat we het coöperatief zo kunnen doen.

\section{5:3 15 in Transcript F}

hubs, hè ook wel knooppunten, en ik denk dat dat de opgave ook in de Achterhoek is. Hoe creëer je bijvoorbeeld zulke locaties waardoor je eigenlijk mensen ook echt op een slimme en schone manier kunt laten reizen. En hoe kies je de locatie? Je weet wat er op bepaalde plekken al gewoon kan. Ook kun je niet altijd alle vormen van mobiliteit bieden. Je kan ook gewoon kiezen om hubs alleen per auto bereikbaar te laten zijn, omdat het anders niet kan. En dan moet die auto elektrisch zijn. En dat is anders in een gebied wat stedelijk is. Dus waar Peter begon, je hebt een opgave en dat is inderdaad de krimp in het gebied tegengaan, het leefbaar houden en daar zit ook een rol voor duurzaamheidscomponenten aan. Ja, en dat is een heel ander gebied van het stedelijk gebied, dus je moet heel goed kijken hoe je dat gebied bereikbaar houdt en zo schoon mogelijk.

\section{5:14 $₫ 44$ in Transcript F}

Daarnaast zijn we een systeem aan het creëren waardoor je eigenlijk ook de verplaatsingen van reizigers ziet. Over de dag heen een heel actueel, dus we zijn aan te kijken of er gewoon door middel van een dashboard ook kunnen zien hoe de reizigers zich te weven en het liefst uit uiteindelijk ook naar een bepaald gebied op bepaalde weg toe $\mathrm{mmm}$. Alleen naast gedragsbeïnvloeding heb je een andere te pakken en dat is data gedreven werken. We zijn als provincie echt bezig van hoe kunnen we nou data gebruiken? Hoe kunnen we beter analyseren, want daar zijn we als overheid niet zo heel goed in. Dus wij hebben veel gesprekken met elkaar. Over het algemeen is het Gelderlands beleid, niet altijd gebaseerd op al die cijfers, want ja die zijn verspreid, hé, wij hebben tot provinciale wegen, maar je hebt natuurlijk ook rijkswegen en je hebt gemeentelijke wegen, dus we zijn echt heel erg aan het kijken van oké kunnen we dan nog verbeteren? Maar op dit moment zijn de onderzoeken er wel naar dat je inderdaad dat trends worden geproduceerd met aantal verplaatsingen per dag actueel en reizigers onderzoeken die we eigenlijk standaard dat doen. En dat is in het openbaar vervoer. En dat is over ook over de wegen. En dan heb je de grote car data, dat zeg je misschien wel wat ja je dat zijn allemaal dingen die wij ook dus daarbij betrekken. 
Ik sprak met onze gedeputeerde nog toevallig hierover, en het enige wat hij noemt is dat er gewoon voor een voorbeeldrol is. Wij willen gewoon met die tien waterstofbussen. Ja, dat zet geen zoden aan de dijk. Dat zijn die elektrische bussen die nu inderdaad in de IJssel vecht concessie rijden. Ja, weet je, dat zijn er een groot aantal. Daar bereik je echt iets in. Die energietransitie alleen dan ook niet heel veel, hè.

\section{5:18 I 56 in Transcript $F$}

Alleen maar waterstof is het gewoon zo dat nog ook een voorbeeld willen uitvoeren, willen soort van sneeuwbaleffect creëren. En dat was eigenlijk de enige reden waarom echt die tien waterstof, dus de gigantisch, veel geld in steken dat het nog niet eens $\mathrm{CO} 2$ heel veel oplevert, hè, want in de productie van waterstof zit ook nog heel $\mathrm{CO} 2$ uitstoot alleen. Het is gewoon een innovatie en het is gewoon niet wat we hopen dat partijen aanwakkert om hier met waterstof tankstations natuurlijk geen en uiteindelijk dat ook goed te krijgen en uiteindelijk ook een goede, een interessante brandstof in 2035.

\section{6:1 ๆ 4 in Transcript $E$}

oor de techniek zit er nu een uitdaging in zorgen dat er een in een rolstoel voertuig komt, wat ze voldoende actieradius heeft, en geen uitstoot heeft.

\section{6:13 $\mid 118$ in Transcript $\mathrm{E}$}

$\mathrm{m}$ toen wij dit aanbestedingstraject gingen starten, heb ik nog even contact gehad van hoe zit het met het waterstof project? Kunnen we daar iets mee? Maar ja, wij moeten wij in juli gaan rijden, dus dat redt je gewoon niet meer dan bouw je te veel onzekerheid in zegt van

\section{6:14 \128 in Transcript $\mathrm{E}$}

Het is dat zowel bij het rijk, hoewel misschien in tegenstelling wat ik net zijn, maar ook bij de provincie, wel dat alles hetzelfde moet zijn en juist door die technologische ontwikkelingen die apps is. Maar de vraag of dat nou echt wel goed is.

Q Travelskills in PT

1 Groups:

Behaviour

5 Quotations:

\section{2:14 98 in Transcript C}

ie vraagt ook een stukje flexibiliteit van de gebruiker. Die moet daar ook een beetje mee om kunnen gaan versus die zekerheid van nou ja, is daar kwart over gaan staan dan komt vier vijf minuten later komt de bus. Mocht het een keer tegenvallen is die tien minuten later, maar hij komt wel heel vaak, negen van de tien keer ja, en dat is toch een hele andere manier van reizen, en ik denk dat die eigenlijk iedereen in de branche die gelooft waarin alle opdrachtgever, alle mensen die er omheen zitten, of het nou Moventem is of een universiteit. Die geloven daar wel in.

\section{2:16 \ा 8 in Transcript C}

Het zou me niks verbazen als we daar in eerste instantie vooral ook reizigers nog gaan verliezen en dat er misschien best nog wel wat tijd overheen gaat voordat er weer een soort nieuwe aanwas komt van reizigers die niet overweg konden met het oude systeem. En dan niet omdat ze het niet begrepen of werkt, maar omdat het ja, ik moet dit om kwart over een, kwart voor, ik wil om half ongeveer, en voor die mensen is er nu geen oplossing

\section{2:17 \ 8 in Transcript C}

Wij gaan dat adopteren, zeg maar die mogelijkheden die er zijn. Ik denk dat daar ook nog wel wat tijd overheen gaat ehm en ik denk dat in het begin ook gaan leren dat het best nog wel complex is om het goed te doen, ook gewoon in de uitvoering. Dus ik denk dat die vorm van duurzaamheid, die gaat de komende twee, drie jaar ook overal uitgerold worden. Ik denk dat we wel gaan ontdekken dat veel mensen nou nog niet echt op zit te wachten, en dat je ook niet zomaar een nieuwe groep reizigers naar het OV krijgt - en dat wordt dan uitdaging op zich want daarmee komt die hele oplossing natuurlijk ook onder druk te staan. Als je iets ouds weghaalt en je vervangt dat voor iets nieuws vanuit een overtuiging dat dat werkt en vervolgens loopt de helft weg, dan ontstaat er natuurlijk enorme druk om dan het oude maar weer terug te halen.

\section{2:29 \ 22 in Transcript C}

Ik denk alleen dat men dreigt snel uit het oog te verliezen, wellicht is dat mensen uiteindelijk altijd maar behoefte hebben aan een vorm van mobiliteit. Het is leuk dat er haltes zijn en fietsen en bussen en treinen, maar ik maak 116 
gebruik van alle zeg maar dus voor de reiziger blijft het gewoon een overstap van mobiliteitsvorm naar de andere mobiliteit voor. En ik heb soms een beetje het idee in deze discussies nogmaals die nog verder uitgewerkt moeten gaan worden. Dat beeld gaat zich ontwikkelen de komende jaren dat men, als er maar veel is, veel fietsen staan en scooters en acties en bussen en deelfietsen, dan denken mensen, daar moet ik naar toe. Terwijl ik denk van ja, mensen denken van ja, ik moet daar gewoon weer overstappen, dus het is niet zo dat als je maar veel hubs neerzet dat mensen dan denken: "nu ga ik gebruik maken van het openbaar vervoer", want liefst hebben ze natuurlijk gewoon een auto voor de deur.

\section{3:20 \ा 54 in Transcript B}

Als ik met de trein reis dan heb ik mijn laptop klepje open, dan kan ik gewoon werken. Het kan in een bus niet. Dat is heel onhandig is. Als ik de bus zou willen nemen dan moet je eerst een half uur in die bus die slingert dan eerst over allerlei bruggetjes en bochtige wegen. Buitengewoon ongemakkelijk als je in die bus zit, je wordt er bijna misselijk van. Nou, dan ga je op de hoofdweg, dat zou je kunnen doen. Alleen dan zit ik net zo graag in mijn auto. Dat snap ik wel, want het gaat dan ook efficiënter. Rechtstreekse dus maar goed, ik spreek uit eigen ervaring -ik reis heel veel met openbaar vervoer, althans in mijn vorige werk, de trein eersteklas, want daar kun je tenminste fatsoenlijk zitten en fatsoenlijk werken. Maar niet in de tweede klas, met allemaal lawaai.

$\nabla$ Willingness

1 Groups:

Behaviour

29 Quotations:

\section{1:13 \ 4 in Transcript D}

Dan zie je bedrijven die op een gat inspringen. Ja, ik weet niet hoeveel auto's en fietsen op gooien en waar ook automatisch gebruik van wordt gemaakt, omdat dat gewoon een hele dichte locaties, dichtbevolkte locaties zijn. $\mathrm{Ja}$, dan dan heb je heel veel vraag naar bepaald vervoer. Vervoersmiddelen in de Achterhoek is dat niet, zoals ik al zei, vanwege het uitgestrekt gebied, dunne lijnen en grote afstanden. Ja, dat maakt het lastig

\section{1:15 I 6 in Transcript D}

heel veel bewegingen worden gemaakt die misschien niet nodig zijn

1:18 $\mathbb{8} 8$ in Transcript D

is dat er heel veel auto's zijn

\section{1:24 \1 13 in Transcript D}

Dat vraagt ook gewoon echt om campagnes en in die campagnes willen wij ook echt duidelijk maken dat bijvoorbeeld een deelauto die wij nou in de kern hebben staan.

\section{1:39 \ा 31 in Transcript D}

Ze worden goed gebruikt, maar ze hadden nog veel beter gebruikt kunnen worden, maar in ieder geval. Wij hadden inderdaad te verwachten dat we dat sowieso al verder konden uitrollen de komende jaren. Misschien moeten we die verwachting iet wat bijstellen, maar er is wel heel veel animo voor, dus er zijn heel veel ondernemingen, ook bij toeristische attracties, bijvoorbeeld die zoiets hebben van hé: 'Dit is een leuk concept, kunnen wij daar ook iets mee? Kunnen wij daar ook risicodeling inzitten om ervoor te zorgen dat die fietsen hier staan?' Dus ja, die animo, die is er zeker en dan merk je ook steeds meer en daar zijn we ook actief mee bezig. Om dat verder uit te rollen.

\section{1:40 \ 37 in Transcript D}

Je kunt je auto's niet parkeren en je bent misschien slecht ter been. Ja, je hebt geen, je hebt geen alternatief op dat moment, want het is nog niet op zo'n grote schaal uitgevoerd. Die deal is dat mensen die deel auto ook echt kunnen laten staan

\section{2:14 II 8 in Transcript C}

ie vraagt ook een stukje flexibiliteit van de gebruiker. Die moet daar ook een beetje mee om kunnen gaan versus die zekerheid van nou ja, is daar kwart over gaan staan dan komt vier vijf minuten later komt de bus. Mocht het een keer tegenvallen is die tien minuten later, maar hij komt wel heel vaak, negen van de tien keer ja, en dat is toch een hele andere manier van reizen, en ik denk dat die eigenlijk iedereen in de branche die gelooft waarin alle opdrachtgever, alle mensen die er omheen zitten, of het nou Moventem is of een universiteit. Die geloven daar wel in. 
Het zou me niks verbazen als we daar in eerste instantie vooral ook reizigers nog gaan verliezen en dat er misschien best nog wel wat tijd overheen gaat voordat er weer een soort nieuwe aanwas komt van reizigers die niet overweg konden met het oude systeem. En dan niet omdat ze het niet begrepen of werkt, maar omdat het ja, ik moet dit om kwart over een, kwart voor, ik wil om half ongeveer, en voor die mensen is er nu geen oplossing

\section{2:17 If 8 in Transcript C}

Wij gaan dat adopteren, zeg maar die mogelijkheden die er zijn. Ik denk dat daar ook nog wel wat tijd overheen gaat ehm en ik denk dat in het begin ook gaan leren dat het best nog wel complex is om het goed te doen, ook gewoon in de uitvoering. Dus ik denk dat die vorm van duurzaamheid, die gaat de komende twee, drie jaar ook overal uitgerold worden. Ik denk dat we wel gaan ontdekken dat veel mensen nou nog niet echt op zit te wachten, en dat je ook niet zomaar een nieuwe groep reizigers naar het OV krijgt - en dat wordt dan uitdaging op zich want daarmee komt die hele oplossing natuurlijk ook onder druk te staan. Als je iets ouds weghaalt en je vervangt dat voor iets nieuws vanuit een overtuiging dat dat werkt en vervolgens loopt de helft weg, dan ontstaat er natuurlijk enorme druk om dan het oude maar weer terug te halen.

\section{2:18 \ा 10 in Transcript C}

Nou, ik denk het belangrijkste woord is, denk ik, gewoon durf en lef, want de politiek is natuurlijk van nature risicomijdend, hè. We kennen allemaal het gegeven dat dat in principe het erover eens bent dat je iets gaat doen of iets gaat proberen en op het moment dat er dan wat protest komt wat je eigenlijk aan de voorkant allemaal uit kon tekenen. Ja, dan wordt vaak ook weer meteen gezegd dat was niet de bedoeling. Dat is natuurlijk suf, het veroorzaakt onrust. Dan is de politiek als eerste degene die zegt: nou, misschien moeten we toch maar gewoon doen wat we altijd deden, of daar terugkomen en ja, dan ga je, dan ga je er ook nooit achter komen.

\section{2:21 T 10 in Transcript C}

Want als er een visie wordt ontwikkeld dan dat moment kun je natuurlijk niks doen, want je, je bent nog bezig met de visie. Dus het eerste wat men doet zodra die klaar is meteen beginnen met een nieuwe voor mij. Dit is wat kritisch, maar dat is echt mijn visie op wat één van de probleem is om steeds verder te komen dat men te veel blijft hangen in het praten over en discussiëren over en het toekomstbeelden, samenstellen, visie, enzovoort, enzovoort. Op een gegeven moment moet je gewoon een keer aan de slag en dan komt die weerstand. En dan komt dus ook ja, de koudwatervrees zeg maar ja en dan het stokt het ja. En dan sta je eigenlijk weer terug bij af, zeg maar. Dat is de grootste uitdaging voor duurzaam: is ook lef van alle partijen. Ook vervoerders natuurlijk hè, want zeker als je als je de eerste bent of zo ja, je kunt ook vreselijk op je bek gaan.

\section{2:29 \ा 22 in Transcript C}

Ik denk alleen dat men dreigt snel uit het oog te verliezen, wellicht is dat mensen uiteindelijk altijd maar behoefte hebben aan een vorm van mobiliteit. Het is leuk dat er haltes zijn en fietsen en bussen en treinen, maar ik maak gebruik van alle zeg maar dus voor de reiziger blijft het gewoon een overstap van mobiliteitsvorm naar de andere mobiliteit voor. En ik heb soms een beetje het idee in deze discussies nogmaals die nog verder uitgewerkt moeten gaan worden. Dat beeld gaat zich ontwikkelen de komende jaren dat men, als er maar veel is, veel fietsen staan en scooters en acties en bussen en deelfietsen, dan denken mensen, daar moet ik naar toe. Terwijl ik denk van ja, mensen denken van ja, ik moet daar gewoon weer overstappen, dus het is niet zo dat als je maar veel hubs neerzet dat mensen dan denken: "nu ga ik gebruik maken van het openbaar vervoer", want liefst hebben ze natuurlijk gewoon een auto voor de deur.

\section{2:34 ๆ 30 in Transcript C}

de verstokte automobilist? Daar moet je geen geld aan besteden in de vorm van campagnes, want dat is gewoon weggegooid geld. De argumenten die je over het algemeen aanhalen waarom ze geen gebruik van het openbaar vervoer zijn niet vaak niet de echte argumenten, want als je het argument wegneemt dan komt er vervolgens wel een ander argument. Het zijn gewoon voor de hand liggende smoesjes, en men gaat daar gewoon niet op overstappen, tenzij het op een gegeven moment wordt gedwongen, hè, dus de binnenstad wordt afgesloten voor autoverkeer. Of zo ja, dan wordt het een ander verhaal. Ik denk ook dat het meest krachten heeft inderdaad om mensen te overtuigen dat het dat het gewoon een prima manier is om te reizen.

\section{2:35 \ा 30 in Transcript C}

Veel collega's van mij overigens ook met niks in om op die sociaal recreatieve reizigers hebben, met name bij evenementen, vind je ook die mensen die eigenlijk nooit in het OV te vinden zijn. Of het nou Koningsdag is dat de 118 
gay parade, gay pride in Amsterdam of Koningsdag bevrijdingsfestival in Wageningen. Die gaan naar de formule één in Zandvoort massaal met de trein. Op dat moment staat met men echt verholpen. Zeg maar, en ik heb mij altijd verbaasd moet zeggen: de laatste jaren gaat het veel beter, hoe wij dat vaak als een gemiste kans hoe dat dan mee omgaan. In het verleden was het dus zo van 'we gaan toch geen extra bus of trein inzetten?!'. Ofzo weet je wel, en dan werd het een chaos. Ja, je maximaal mensen moeten op op het moment dat ze dan een keer het OV gebruiken. En dan gaat het vaak om de treinen. Ook dan moet je dus ook gewoon die beleving geven dat het gewoon hé.

\section{2:36 \ 30 in Transcript C}

e dat mensen die ga ik wel eens in moet overwegen - wijziging maar die mindset, die moet je gewoon aanpassen. 2:37 \ा 30 in Transcript C

Ik ben nou ook zelf een automobilist, dus ik ben bewust van wat ik zeg, maar die moet je dan gewoon treiteren. Dat is gewoon de beste manier. Om uit de auto te krijgen belonen. Er weegt geen beloning op tegen die van het comfort en gemak van je eigen auto, zeker als die gratis is zoals die ik heb, gewoon een leaseauto. Ik betaal maar niks in totaal geen allerlei.

\section{2:38 \ा 36 in Transcript C}

Nou kun je daar nog tegenoverstellen, ja, die mensen die zitten beroepsmatig op de bus, ja dus denk je nou echt dat die dan wel in een vrije tijd ook nog in de bus gaan zitten. Dat geloof ik ook wel een beetje, zien ze zo'n collega weer. Dat voelt misschien als werk, dus dat is misschien toch een beetje van ja, oké, ik sta als kok in een restaurant b, ga ik dan in dit weekend op mijn vrije dag eten in restaurant b weet je wel, dus daar kan ik me wel iets bij voorstellen. Maar toch ja, ja, die mensen hebben gewoon een auto en zelfs die buschauffeur geeft op dat moment de voorkeur aan zijn auto. Dus dat is toch wel heel erg opmerkelijk. Maar als je zelfs die groep met een gratis abonnement aan alle kennis die ze hebben al niet kunt overtuigen om die altijd te laten staan, nou, dan weet je dat je een gewoon hele strijd te gaan hebt.

\section{2:45 ๆ 52 in Transcript C}

ik denk dat je dan mogelijk ook het moment bereikt waarop mensen MaaS-mobiliteit inderdaad hebben ontdekt. Arriva is een partij die investeert, maar dat zijn heel veel partijen die daarin investeren, ook allemaal met een business case eronder. Als ik heel eerlijk ben, denk ik dat veel mensen daarin nog wel teleurgesteld gaan raken, de eerste jaren in relatie tot de verwachte opbrengsten, omdat je volgens mij toch altijd te positief wordt gedacht. Over die gedrag is aanpassingen. Mensen zitten vast in bepaalde gedragingen. Die zijn er echt niet zomaar uit te krijgen, ook al heb je goede tools en goede middelen, en het OV zelf is daarvan een prima voorbeeld. Dat hebben het net ook al besproken, want ze gaan echt niet zomaar van af. Ik denk dat daar de verwachtingen wel wat overspannen zijn, maar dat je dus inderdaad over 10-15 jaar.lk denk nee, maar over tien 15 jaar kan ik me voorstellen dat mensen wel bereid zijn om die gedrag aanpassing op zichzelf toe te gaan passen en dat men dat gaat ontdekken. En ik geloof ik echt in een sneeuwbaleffect. Niemand doet het, dus ik doe het ook niet totdat je in je omgeving op een gegeven moment mensen ziet die dat doen en die je meenemen samen. Kijk je dit aan, oké, oh, dat is eigenlijk zo makkelijk. Nou, en op een gegeven moment, dan ben je om, want die omgeving heb je voldoende mensen die doen. Dus je hebt bepaalde voorbeeldfunctie is. En dan pak je dat op en ik denk dat we over tien 15 jaar wel ongeveer zo ver zijn dat mensen Maas.

\section{3:7 शा 22 in Transcript B}

kijk in mobiliteitsbeleid en onderzoek gaat het vaak over efficiëntie. Dit is natuurlijk niet waar reizigers mee bezig zijn. Reizigers gaat het gewoon om comfortabel van de plek van herkomst naar de plek van bestemming te gaan. En dan gaat het gaat soms ook om heel andere dingen: voorkeuren of statussymbool, of het plezier van de verplaatsing.

\section{3:11 ๆ 34 in Transcript B}

Misschien ook wel één van de meest opmerkelijke uitkomsten is dat mensen hier zo dicht bij hun werk wonen. Dus dat betekent - en dat zie je ook op een industrieterrein, heel veel mensen op de fiets of met de auto omdat ze gewoon autorijden leuk vinden of niet. Daar waar het veronderstelde probleem zit dat is bij nieuwe medewerkers, ook jonge medewerkers, hoe krijg je die nou op de werkplek? En hoe gaan mensen ook zien dat werkplekken ergens op een industrieterrein in Steenderen of Hengelo of Ulft of zo, dat dat ook een optie is als je in Arnhem zit en dan kom je daar daardoor. Als je dan een auto hebt, dan is ook best wel weer een afstand en tijd hebben. Ook kan je natuurlijk met het OV, maar heel veel werk locaties zijn helemaal niet bereikbaar met het OV. Zo kan je ook 
vragen aan ondernemers: wat denken jullie dat kansrijk is? Kun je ook samenwerken als bedrijf om iets van een pendeldienst ofzo te laten draaien? Het OV systeem is daar vrij slecht op ingericht.

3:12 \ा 36 in Transcript B

Kijk, het auto rijden is het meest logische en voor de hand liggende vervoerswijze als je auto kunt rijden, dus als je oud genoeg bent om eem rijbewijs te hebben en als je ook nou niet andere beperking hebt om auto te rijden. En je kan kijken wat een auto nou echt voor de mensen kost.

3:17 शा 46 in Transcript B

. We hebben hier in de Achterhoek gewoon iets anders. De achterhoek monitor laat dan zien dat mensen dus heel wonen heel dicht bij hun werk wonen. Ja, ja, op papier. Als dat bedrijf gevestigd is op het industrieterrein Hengelo je woont in Hengelo, dan kun je net op de fiets naar je werk. Maar als je vervolgens met een busje van dat bedrijf jouw werkzaamheden daadwerkelijk uitvoert, omdat je installatie technicus bent, ja, dan is het toch weer een ander verhaal. Een ander verhaal is dan die mobiliteit. Als je om vijf uur opstaat om om half zeven in Amsterdam aan de 
slag te kunnen, nou, dan heb je dus toch wel die afstand naar Amsterdam gereden en er zijn best veel mensen die het doen. Dus het lijkt heel kort bij, want het is natuurlijk ook niet. Kijk uit inderdaad met die aannames.

\section{3:18 \ा 48 in Transcript B}

drie vier belangrijkste vervoersmotieven en zoek naar de kansrijke onderdelen van het verplaatsen en probeer daar nieuwe vervoersconcepten of mobiliteitsaanpak in te ontwikkelen. En moet dat dan duurzaam zijn of niet? Ja, dat ligt er naar het vertrekpunt van je beleid, dat is een keuze dat kan. Maar ja, er is natuurlijk niks op tegen, dus ik wil daar niks van af doen. Dat is een belangrijk beleidsmotief: je moet je wel realiseren dat als je wil aansluiten bij de leefwereld van de reiziger dat dat niet per se hoeft te betekenen dat die reiziger ook heel graag een duurzaam mobiliteitsalternatief wil.

\section{3:19 ๆ 51 in Transcript B}

Mensen zijn kennelijk bereid heel veel geld uit te geven en ook als je een fiets koopt

\section{3:20 ๆ 54 in Transcript B}

Als ik met de trein reis dan heb ik mijn laptop klepje open, dan kan ik gewoon werken. Het kan in een bus niet. Dat is heel onhandig is. Als ik de bus zou willen nemen dan moet je eerst een half uur in die bus die slingert dan eerst over allerlei bruggetjes en bochtige wegen. Buitengewoon ongemakkelijk als je in die bus zit, je wordt er bijna misselijk van. Nou, dan ga je op de hoofdweg, dat zou je kunnen doen. Alleen dan zit ik net zo graag in mijn auto. Dat snap ik wel, want het gaat dan ook efficiënter. Rechtstreekse dus maar goed, ik spreek uit eigen ervaring -ik reis heel veel met openbaar vervoer, althans in mijn vorige werk, de trein eersteklas, want daar kun je tenminste fatsoenlijk zitten en fatsoenlijk werken. Maar niet in de tweede klas, met allemaal lawaai.

\section{3:22 \ा 60 in Transcript B}

Ze hoeven niet uit de auto, dus dat is een belangrijk uitgangspunt. Dit wordt vooral door Europees beleid en landelijk beleid veroorzaakt. Subsidiestroom dus

\section{4:2 \ 2 in Transcript A}

. Nou, en het tweede is denk ik wel dat kijk als je kijkt naar elektrisch vervoer en het opladen voor elektrisch vervoer. Daar leeft toch wel een beetje. Denk de gedachte dat het bijna nergens kan, terwijl er toch heel veel plekken in de achterhoek zijn waar het wel kan en die plekken gaan uitbreiden. Zeker vanuit het actieplan laadinfrastructuur. Ik heb het idee dat die dat die bewustwording dat men ook weet dat je overal kunt laden, dat het eigenlijk prima is om hier gewoon ook elektrisch bijvoorbeeld kunnen rijden, ja, dat er is, dus het is vooral gedragsverandering en met name bekendmaking.

\section{4:9 1 39 in Transcript A}

Dus je probeert door dat eigenaarschap laag te leggen, natuurlijk al een soort van hè, dat noaberschap was dan ook wel vaak genoemd wordt, maar dat gevoel te creëren van het is ik, ik ben onderdeel van de club. Zou ik bijna zeggen, dus het voelt niet zozeer als ik ben klant, maar ik ben meer lid. Dat is toch een verschil.

\section{5:18 \ 56 in Transcript $F$}

Alleen maar waterstof is het gewoon zo dat nog ook een voorbeeld willen uitvoeren, willen soort van sneeuwbaleffect creëren. En dat was eigenlijk de enige reden waarom echt die tien waterstof, dus de gigantisch, veel geld in steken dat het nog niet eens $\mathrm{CO} 2$ heel veel oplevert, hè, want in de productie van waterstof zit ook nog heel $\mathrm{CO} 2$ uitstoot alleen. Het is gewoon een innovatie en het is gewoon niet wat we hopen dat partijen aanwakkert om hier met waterstof tankstations natuurlijk geen en uiteindelijk dat ook goed te krijgen en uiteindelijk ook een goede, een interessante brandstof in 2035. 



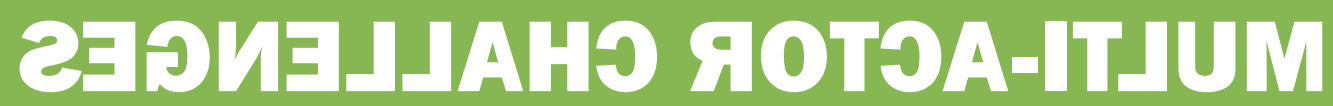 OИA TИEM9OJEVEC Я07 EJgAИIATEUE 70 ИOITATИEMEJ JMI

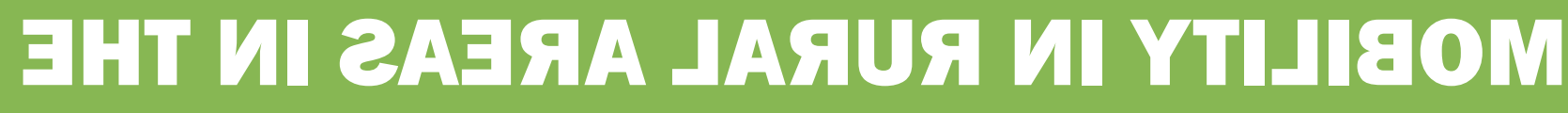 อОИАJGEHTEИ}

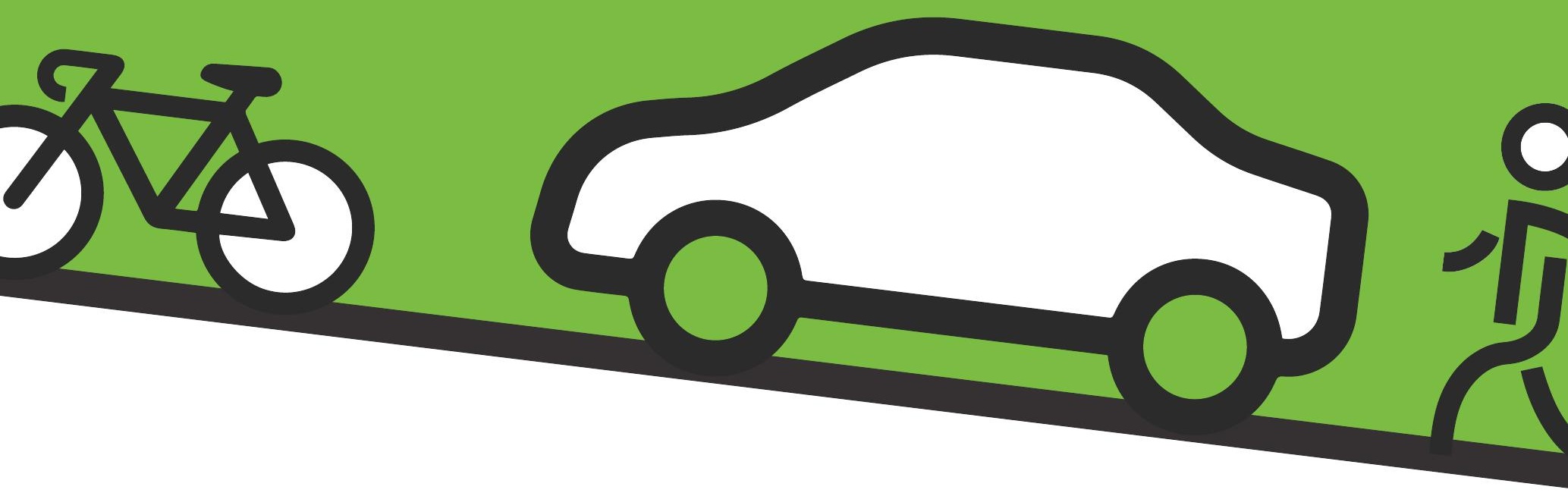

2I2ЭHT ЯتT2AM

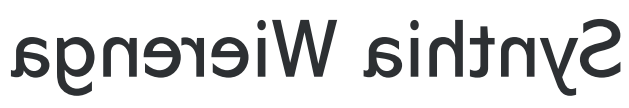

